\author{
UNIVERSIDADE DE SÃO PAULO \\ ESCOLA DE COMUNICAÇÃO E ARTES
}

Departamento de Artes Cênicas

MARIA CELINA GIL

\title{
Os potenciais narrativos do bordado no traje de cena
}

SÃO PAULO 
MARIA CELINA GIL

\section{Os potenciais narrativos do bordado no traje de cena}

Dissertação

Dissertação apresentada ao programa de Pósgraduação em Artes, Área de Concentração Teoria e Prática do Teatro, Linha de Pesquisa História do Teatro, da Escola de Comunicação e Artes da Universidade de São Paulo, para a obtenção do título de Mestra em Artes.

Orientador: Prof. Dr. Fausto Roberto Poço Viana

SÃO PAULO 
Autorizo a reprodução total ou parcial deste trabalho, por qualquer meio convencional ou eletrônico, para fins de estudo e pesquisa, desde que citada a fonte.

Catalogação na Publicação

Serviço de Biblioteca e Documentação

Escola de Comunicações e Artes da Universidade de São

Paulo Dados inseridos pelo(a) autor(a)

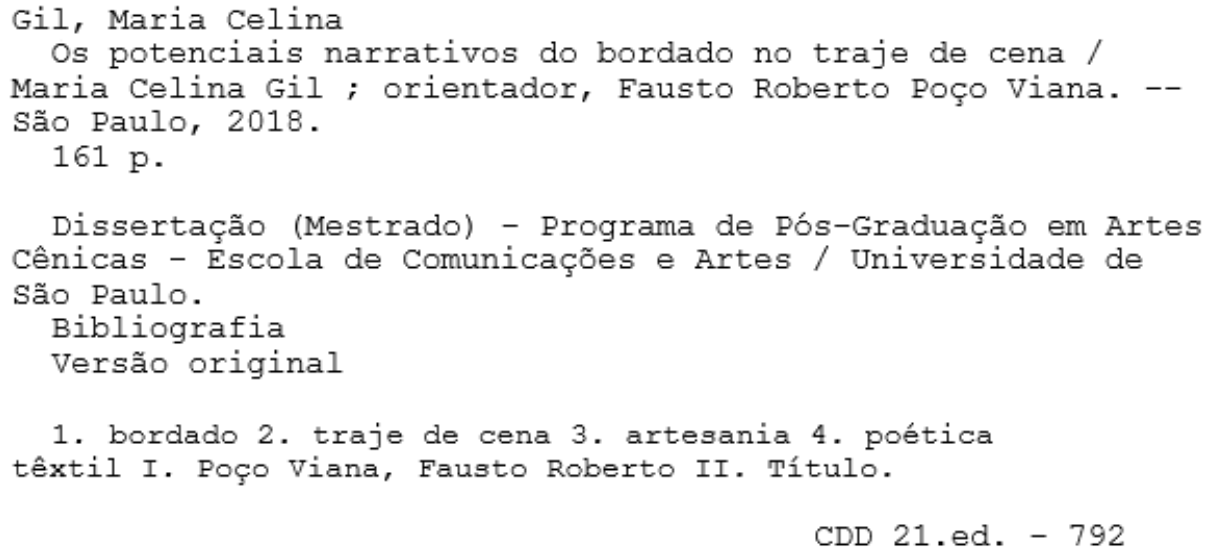


NOME: GIL, Maria Celina

TÍTULO: Os potenciais narrativos do bordado no traje de cena

Dissertação apresentada à Escola de Comunicação e Artes para a obtenção do título de Mestra em Artes.

Aprovada em:

Banca examinadora:

Orientador: Prof. Dr. Fausto Roberto Poço Viana

Instituição: CAC ECA USP Julgamento:

Assinatura:

Prof. Dr.

Instituição:

Julgamento:

Assinatura:

Prof. Dr.

Instituição:

Julgamento:

Assinatura:

São Paulo, de 2018 . 
Para mamãe e vovó, que me ensinaram a amar as linhas, as palavras e as narrativas 
Minha mãe e minha avó, pelo apoio durante a pesquisa e a vida. Obrigada por sempre me incentivarem a ser mais. Vocês são tudo. Amo vocês.

Fausto, por ser o melhor orientador (além de amigo) que alguém poderia querer. Que sorte a minha cruzar meu caminho com o seu em 2014.

Isabel Italiano e Dalmir Pereira, pela banca de qualificação e pelas conversas do dia a dia. Vocês foram essenciais para dar vida a essa pesquisa.

Aos alunos de Têxtil e Moda de 2017, que me deram seu tempo e seu talento. Parte da pesquisa é de vocês também.

Working Group de Cenografia do IFTR, que desde o início colaborou com o desenvolvimento dessa pesquisa.

As companheiras de pesquisa no traje de cena: Renata Cardoso, Tainá Macedo e Carolina Bassi. É um orgulho estar cercada de mulheres incríveis na vida acadêmica.

Núcleo de pesquisa de traje de cena, indumentária e tecnologia. Juntos, construímos amizades, conhecimento e companheirismo em meio a caixas, fotografias e almoços.

Claudia, Rayssa e Guilherme, meus companheiros, meus amores eternos.

Fernando e Marcela, que me apoiam e entendem minhas ausências. A academia me chama, mas eu sempre volto pra vocês.

Marci e Mariana, o presente maior que a Letras poderia ter dado. Dez anos de nós 3.

Higor, pelo nosso dia a dia, pela calma que você me dá, pelas aventuras que eu ainda quero viver com você.

Colegas da Pós, pelas conversas e trocas. Em especial George e Margô, cuja criatividade e talento foi essencial.

Coletivo Inominável, pela nossa Bernarda Alba e por toparem minhas loucuras têxteis. Assim deviam ser todas as mulheres (e os homens também).

Companheiros do Latim, em especial Diogo e Sílvia, sempre presentes. gratias tibi ago.

Por fim, minhas amigas das linhas, bordadeiras que dividem comigo esse ofício e amor na cidade de São Paulo. Que alegria criar essa rede. O mundo, nós o teceremos. 
O tempo é um tecido invisível em que se pode bordar tudo, uma flor, um pássaro, uma dama, um castelo, um túmulo. Também se pode bordar nada. Nada em cima de invisível é a mais subtil obra deste mundo, e acaso do outro.

(Machado de Assis, Esaú e Jacó) 


\section{RESUMO}

Esta pesquisa busca investigar a presença do bordado no traje de cena, não só como elemento decorativo, mas também como elemento narrativo. Importam para esta reflexão o processo de produção manual, a artesania - principalmente a partir dos estudos de Richard Sennett - e poéticas têxteis que o bordado pode produzir. Partindo da relação entre o ato de tecer e o de narrar presente em Walter Benjamin e Roland Barthes, a pesquisa traça um breve histórico do bordado, entendendo de que maneiras e com que objetivos ele foi usado em trajes de diversos tipos, principalmente no traje de cena. Dois estudos de caso são objeto de análise nesta pesquisa: os trajes do espetáculo O homem de la mancha (2014), de Miguel Falabella; e processos criativos do encenador Gabriel Villela. O que liga ambos os casos é o artista Arthur Bispo do Rosário. Bispo produziu grande parte de suas obras quando esteve internado no hospital psiquiátrico. O bordado era uma das principais técnicas utilizadas por ele, cujo trabalho era marcado pelo alto grau de detalhes e pela ressignificação de objetos do cotidiano. Em O homem de la mancha, os trajes de cena foram inspirados em obras têxteis de Bispo. Já Villela assume ser Bispo uma de suas maiores inspirações e seus processos criativos se assemelham sobremaneira. Além de uma reflexão teórica sobre o que se tem produzido contemporaneamente no teatro envolvendo a artesania e o bordado, foi proposto ao longo da pesquisa um exercício prático utilizando a técnica como plataforma. Esse experimento, realizado junto aos alunos do curso de Têxtil e Moda no ano de 2017, foi uma criação coletiva em oficinas, cujos processos são relatados aqui. O ponto de partida das discussões e processos que resultaram nesse experimento foi a peça $A$ mulher como campo de batalha, de Matéi Visniec. A peça trata de duas mulheres, internadas em um sanatório, dividindo suas experiências e ressignificando suas memórias. Essa peça foi escolhida por lidar com questões pertinentes à técnica do bordado: o gênero, a criação coletiva e a memória. 


\section{ABSTRACT}

This research seeks to investigate the presence of embroidery in the theatre costume, not only as a decorative element, but also as a narrative element. The manual process of production, the artisanship - especially the studies of Richard Sennett - and the textile poetics that embroidery can produce are important for this reflection. Starting from the relationship between weaving and narration presented by Walter Benjamin and Roland Barthes, the research traces a brief history of embroidery, understanding in what ways and for what purpose it was used in various types of clothing, especially in the costumes. Two case studies are the subject of analysis in this research: the costumes of the play O homem de la mancha (2014), by Miguel Falabella; and creative processes of the stage director Gabriel Villela. What binds both cases are the artist Arthur Bispo do Rosário. Bispo produced a great part of his works during his time in the psychiatric hospital. Embroidery was one of the main techniques used by him, whose work was marked by the high degree of detail and the resignification of everyday objects. In $\mathrm{O}$ homem de la mancha, the costumes were inspired in textile works of Bispo. On the other hand, Villela admits Bispo is one of his greatest inspirations and their creative processes are very similar. In addition to a theoretical reflection on what has been produced contemporaneously on theatre involving craftsmanship and embroidery, a practical exercise was proposed throughout the research using the technique as a platform. This experiment, carried out with the students of the course of Textile and Fashion in the year 2017, was collectively created during workshops, whose processes are reported here. The starting point for the discussions and processes that resulted in this experiment was the play The body of a woman as a battlefield in the Bosnian war by Matéi Visniec. The play deals with two women, hospitalized in a sanatorium, dividing their experiences and resignifying their memories. This play was chosen for dealing with issues pertaining to the technique of embroidery: gender, collective creation and memory. 


\section{LISTA DE FIGURAS}

Figura 1- Casaco de noite Elsa Schiaparelli com bordados Maison Lesage (1937) ................p22

Figura 2- Detalhe de bordado botânico de traje elisabetano....................................................25

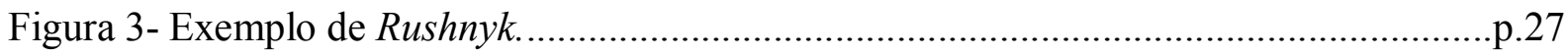

Figura 4- Casula (aproximadamente 1434-1446) do Duque de Warwick.............................p.30

Figura 5- Detalhe de jaqueta feminina chinesa do séc. XIX............................................p.31

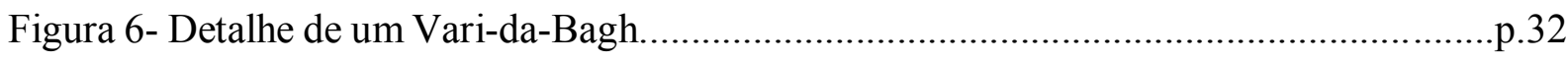

Figura 7 - Suéter Latham Thomas......................................................................p. 35

Figura 8- Peça de Tessa Perlow....................................................................................p. 35

Figura 9- Jaqueta militar de gala francesa do séc. XIX com detalhes bordados dourados.......p.38

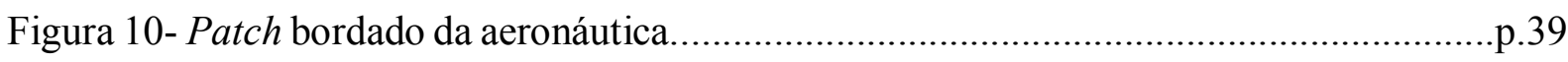

Figura 11- Armadura alemã de 1525, feita em aço e ouro, mimetizando tecidos adornados...p.39

Figura 12- Casula sugerida para o período de Pentecostes................................................p.40

Figura 13- Rum de Iansã bordado com borboletas......................................................p.41

Figura 14- Trajes regionais de Viana do Castelo.................................................................43

Figura 15- Exemplo de lenço de namorado da região do Minho............................................p.43

Figura 16- Peça da coleção Sera da Dolce \& Gabanna (S/S17) ..........................................p.44

Figura 17- Detalhe do logo bordado em uma camisa Lacoste...............................................p.44

Figura 18- Detalhe de jaleco bordado com nome, profissão e universidade do usuário............p.44

Figura 19 - Corset da Royal Worcester Corset Company (1876) adornado com bordados......p.45

Figura 20 - Nomes bordados aplicados na anágua de um vestido de noiva............................p.46

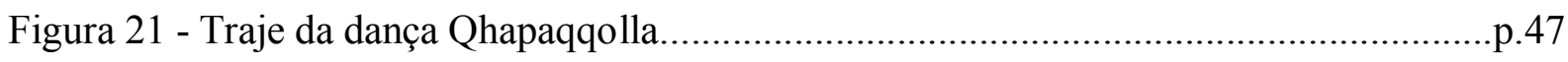

Figura 22 - Camisa do Internacional (Outubro Rosa - 2017) ...........................................p.48

Figura 23 - Gabriella Papadakis e Guillaume Cizeron.....................................................p.48 
Figura 24 - Detalhe do corpete de Eleonora de Toledo .p.49

Figura 25 - Mortalha bordada com inscrição personalizada na borda....................................p.50

Figura 26 - Avental para Primeiro Vigilante bordado .p. 51

Figura 27 - Trajes etnográficos da Moldávia do século XIX (A noiva e sua mãe), no Museu Etnográfico Russo. p. 52

Figura 28 - Condessa Almaviva, de As Bodas de Fígaro, Opera de Paris (1973) ..................p.54

Figura 29 - Figurino da novela Orgulho e Paixão (2018) ……...............................................55

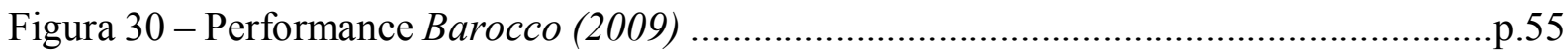

Figura 31 - Traje para Sonhos de uma noite de verão.......................................................p58

Figura 32 - Patricia McBride, Violette Verdy, Mimi Paul e Suzanne Farrell em Jewels, de George Balanchine (1967) .p.60

Figura 33- Detalhe do traje Esmeralda, usado por Violette Verdy. (1967) ..............................61

Figura 34 - Patricia McBride e Edward Villella com os trajes de Rubi. (1967) .......................6.62

Figura 35 - Suzanne Farrell usando o traje Diamantes (1967) ..........................................p.63

Figura 36- Antonin Artaud em cena em Os cenci (1935) .......................................................64

Figura 37- Detalhe de lobo bordado em traje de Sansa..............................................................67

Figura 38 - Detalhe de peixe bordado em traje de Sansa......................................................6. 67

Figuras 39 e 40 - Vestido Azul de Cersei (2011) ......................................................................68

Figura 41 - Detalhe da parte de trás do vestido de Sansa...................................................p.71

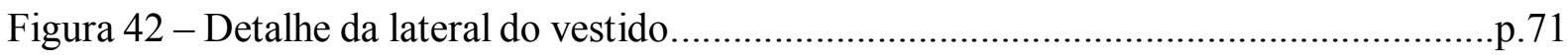

Figura 43 - Detalhe do pescoço do vestido.......................................................................p.71

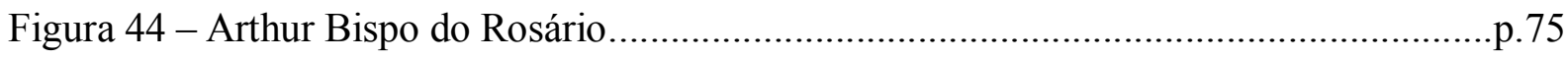

Figura 45- Rei Mouro em uma Chegança....................................................................p. 77

Figura 46- Manto da Apresentação.....................................................................................p.79

Figura 47 - Visão interna do Manto da Apresentação..........................................................p. 80 
Figura 48 - Adeus do Marujo, de João Cândido (1910/1911) ....................................................85

Figura 49 - Amor do Marujo, de João Cândido (1910/1911) ...............................................p.86

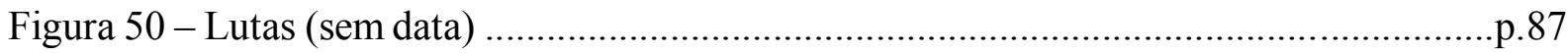

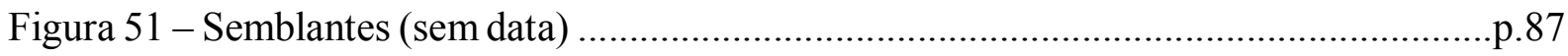

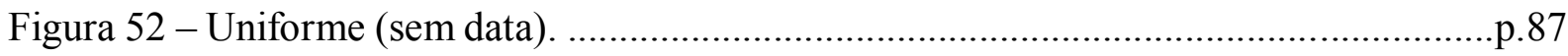

Figura 53 - Cenografia da montagem original de $\mathrm{O}$ homem de la Mancha...........................p.92

Figura 54 - Dom Quixote e Sancho Pança...........................................................................p.93

Figura 55 - Dom Quixote e o Dono da Pensão/ Governador................................................p.93

Figura 56 - Cenografia do espetáculo brasileiro............................................................p.95

Figura 57 - Paineis com coleções de objetos...............................................................p. 95

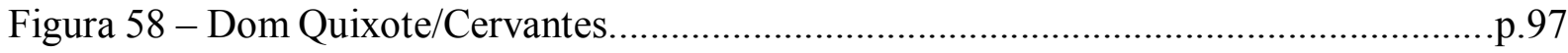

Figura 59 - Croqui da Mulher do Hospedeiro........................................................................p.98

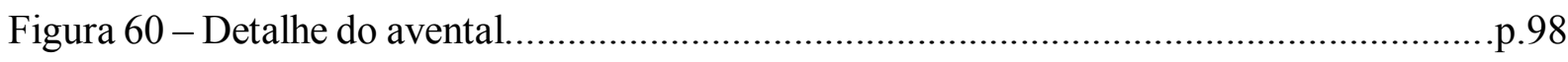

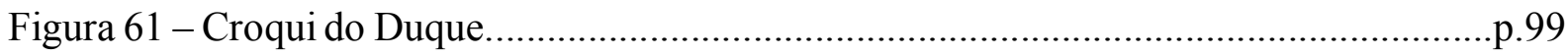

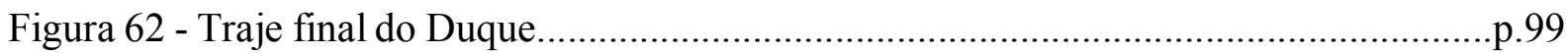

Figura 63 - Guilherme Sant'Anna com o primeiro traje usado no espetáculo...........................p.100

Figura 64 - Detalhe do traje do Governador....................................................................... 100

Figura 65 - Traje inspirado na obra Semblantes........................................................p. 101

$\begin{array}{llllll}\text { Figura } & 66 \quad- & \text { Guilherme } & \text { Sant'Anna caracterizado } & \text { como }\end{array}$ Bispo/Governador...........................p.101

Figura 67 - Romeu e Julieta do Grupo Galpão................................................................p. 102

Figura 68 - Luana Piovani em Mania de Explicação (2014) ...............................................p.105

Figura 69 - Luiz Araújo em Mania de Explicação (2014) ..................................................p.105

Figura 70 - O soldadinho de chumbo e a bailarina (2010) ...............................................p. 108 
Figura 71 - Detalhes em pedrarias na gola e gargantilha................................................p.108

Figura 72 - Trajes reelaborados em Gigantes da Montanha.............................................p.109

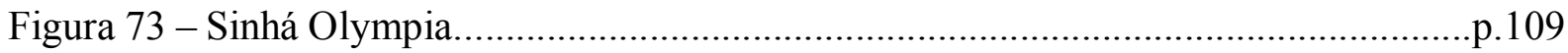

Figura 74 - Personagem com adereço inspirado em Sinhá Olympia...................................p.109

Figura 75 - Detalhe bordado por Giovanna em traje de A Tempestade (2015) ...................p.111

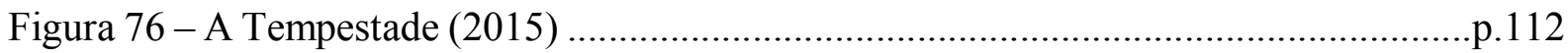

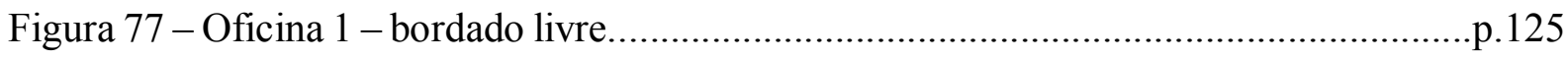

Figura 78 - Oficina 2 - Quadrados bordados.............................................................p.126

Figura 79 - Oficina 3 - Bordado sobre fotografia.........................................................p. 126

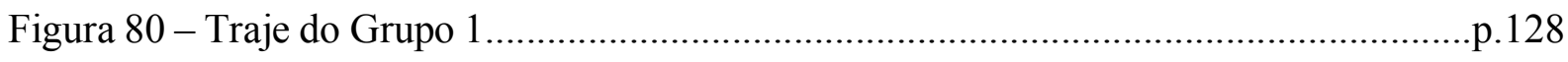

Figura 81 - Quadro A coluna partida (1944), Frida Khalo...............................................p.129

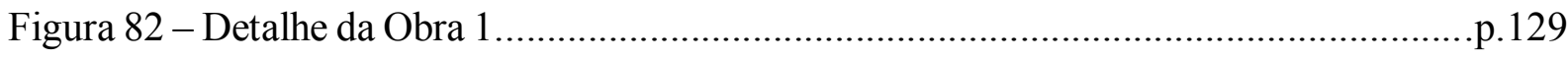

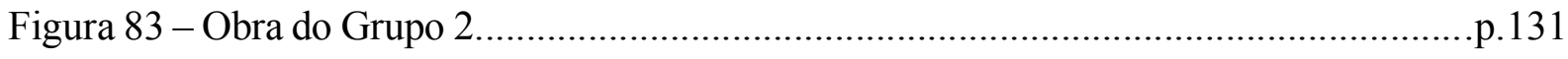

Figura 84 -Detalhe das faixas da obra do Grupo 2 ....................................................p.131

Figura 85 - Projeto e maquete do Grupo 2 .................................................................p.132

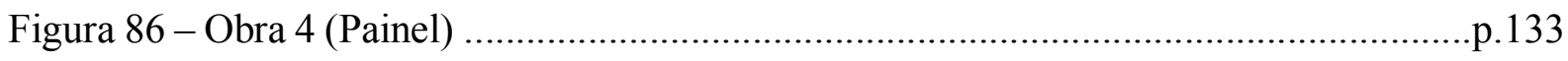

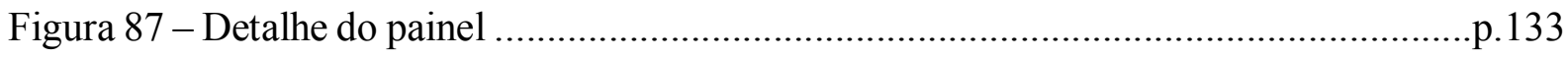

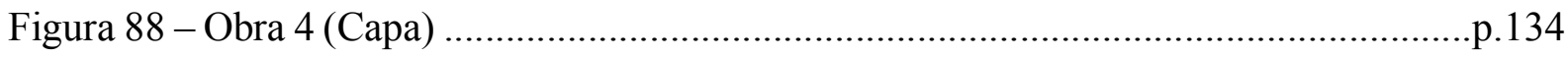

Figura 89 - Detalhe dos dados escritos na capa …...................................................p. 134 


\section{SUMÁRIO}

Introdução. ..p. 14

Capítulo 1 - Uma breve história dos usos do bordado. p. 18

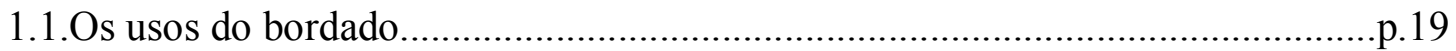

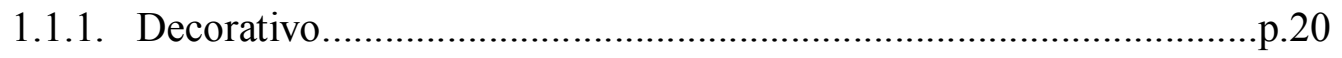

1.1.2. Identificação..........................................................................p. 23

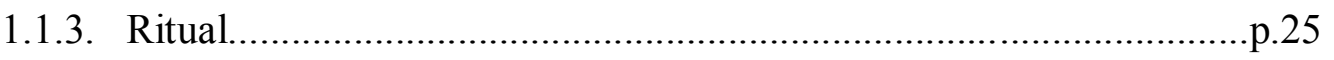

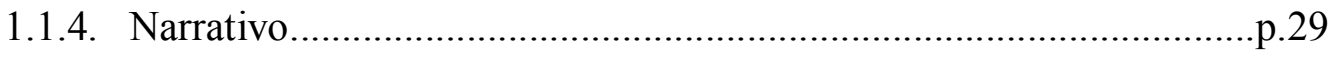

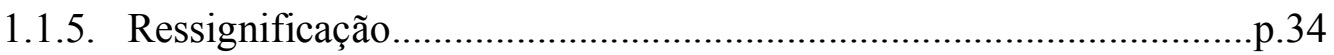

1.2. Usos do bordado em diferentes tipos de trajes................................................p.36

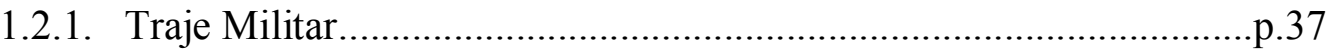

1.2.2. Traje Eclesiástico.....................................................................p. 40

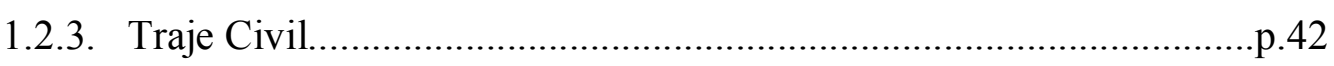

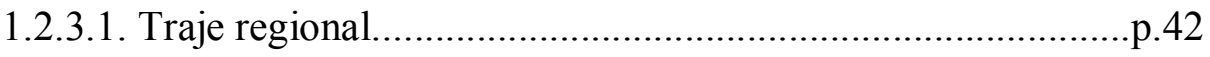

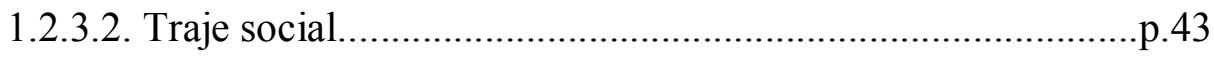

1.2.3.3.Traje profissional..............................................................p. 44

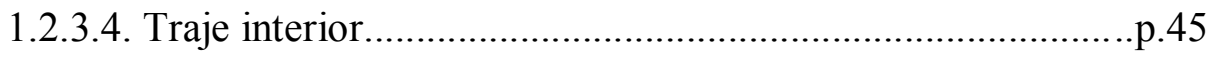

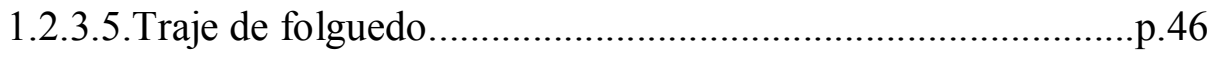

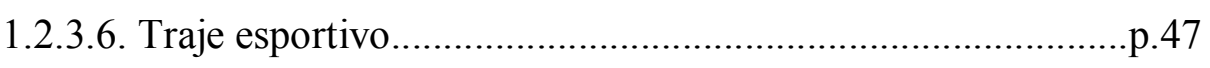

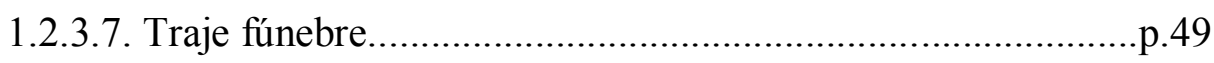

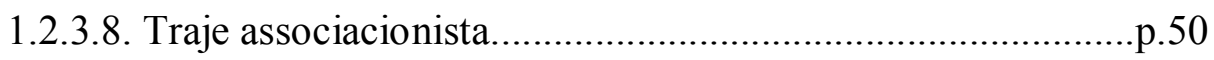

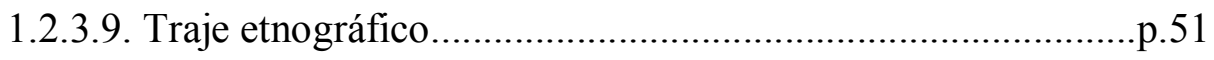

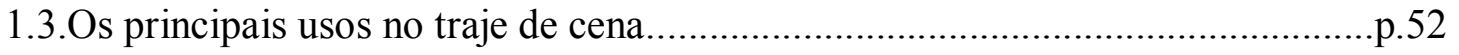

1.3.1. Uso decorativo em Jewels (1967) ..................................................p.56

1.3.2. Uso narrativo em Game of Thrones (2011) ...................................p.65

Capítulo 2 - Estudos de caso: Bispo do Rosário, bordados e o teatro...................................p. 73

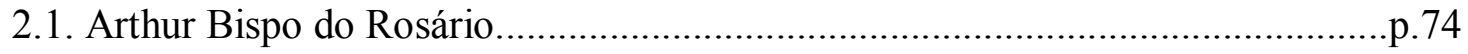

2.1.1. Apresentação do manto: o folguedo.................................................p. 76

2.1.2. Ulisses-Penélope: a marinha......................................................p. 80

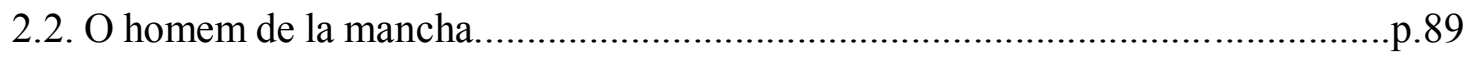


2.2.1. O primeiro cavaleiro andante..........................................................p. 90

2.2.2. Miguel não Cervantes: Falabella....................................................p. 94

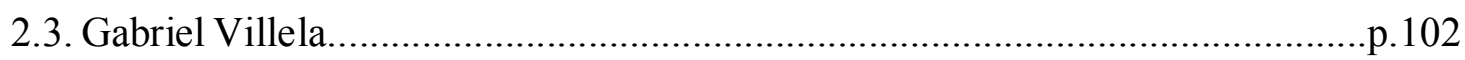

2.3.1. Bispo e Villela se encontram..................................................p.104

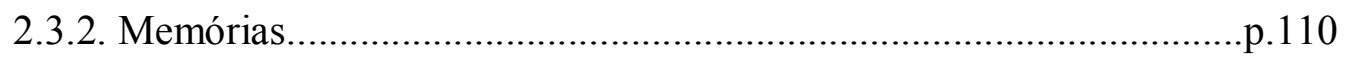

2.4. Poéticas têxteis..................................................................................p. 113

Capítulo 3 - Exercício prático: A mulher como campo de batalha......................................p.115

3.1. O bordado e as mulheres.....................................................................p. 116

3.2. A mulher como campo de batalha..............................................................p. 119

3.3. Exercício Prático - EACH......................................................................p. 124

3.3.1. Obra 1 - Influência da moda.......................................................p. 127

3.3.2. Obra 2 - Bordado etnográfico................................................p. 130

3.3.3. Bordado contemporâneo...............................................................p. 132

3.3.5. Conclusões sobre o experimento.................................................p. 136

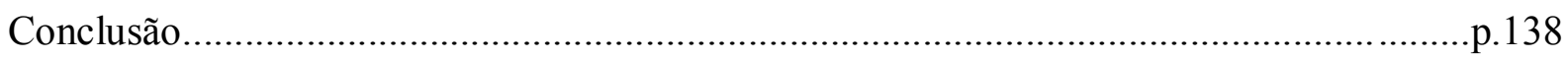

Referências Bibliográficas................................................................................p. 144

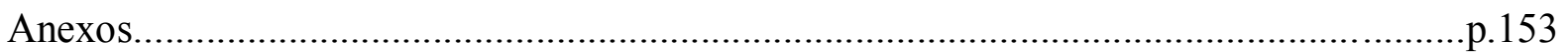

ANEXO I - EXEMPLO DE PROJETO.......................................................p. 154 


\section{Introdução}

Esta pesquisa parte ao mesmo tempo de uma prática individual e de uma percepção da carência de pesquisas sobre a artesania nas artes cênicas. Trabalho com bordado e arte têxtil há muitos anos e, de maneira natural, os processos de produção artesanais se fizeram presentes na minha atuação como diretora de arte e figurinista. Na realização destes trabalhos pude perceber como a artesania é capaz de transformar os objetos e lhes conferir significados. Ao passo em que vivia na prática esses processos intensamente, encontrava pouca bibliografia dedicada a investigar a artesania em camadas mais profundas. Quando me propus a realizar um levantamento bibliográfico sobre o bordado, encontrei muitos materiais que ensinavam os modos de realização da técnica, um bom número de materiais que analisavam bordados típicos de civilizações ou períodos históricos, mas nenhum material que olhasse para esta técnica em relação às artes cênicas. Assim começou minha investigação sobre o bordado e seus potenciais narrativos nos trajes de cena.

A opção por pesquisar especificamente o bordado e seus usos no traje de cena partiu de uma série de elementos que tangem essa técnica. O bordado é uma das maneiras mais antigas de se adornar um traje. O que se percebe, porém, é que muitas vezes o bordado é utilizado não só como forma de criar interesse visual. Além de assumir uma função decorativa, ele também pode criar narrativas e trazer diferentes informações, tanto para o público quanto para o próprio ator.

O bordado é envolto numa tradição antiga. Por ser uma técnica muito presente no cotidiano, ela dialoga com diversos momentos históricos. Tipos de bordado diferentes remetem a povos e circunstâncias com significados múltiplos. Além disso, há muita tradição pessoal ligada a ele: usos familiares, modos de feitura particulares ligados à comunidades e estruturas íntimas. Toda essa presença histórica - tanto nos macros quanto nos microuniversos - comunica diferentes mensagens quando o bordado aparece no palco.

O status que o bordado assume ao longo do tempo também traz informações importantes e que podem trazer novos significados quando usado em trajes de cena: ele é considerado artesanato, não arte. Não é possível dizer com certeza o que faz algo ser arte ou não. Quanto ao bordado, talvez dois traços sejam bastante definidores: o fato de ser uma prática do cotidiano e, portanto, sem a pretensa elevação necessária à arte; e o fato de que ao longo do tempo ele tenha sido deixado muito mais ao cargo das mulheres do que aos homens. Se o gênero muitas vezes é um dado definidor de hierarquia, parece que o bordado pode ter sido considerado 
artesanato, comumente referido como hierarquicamente abaixo da arte, também por este motivo.

Além dos significados e relações sociais dessa técnica, investigar os usos do bordado nos trajes de cena também leva a questionamentos acerca dos processos criativos e de feitura manual dos trajes. Através do bordado também pode-se pensar como o processo de feitura de um traje pode influenciar no seu resultado. É também possível pensar como este traje se conecta ao trabalho do ator e, em alguma medida, o auxilia na criação de sua personagem. Também tendo em vista toda a tradição que o envolve, é possível pensar quais os efeitos que esta técnica causa na plateia e a que outros significados externos ela remete.

O bordado pode ser tanto um elemento decorativo quanto narrativo na criação de uma poética pessoal do artista. É também possível fonte de recriação de trajes e figurinos já utilizados anteriormente, trazendo novos códigos e signos que modificam o pré-existente.

Os objetivos principais desta pesquisa são, portanto, compreender quais são os potenciais narrativos do bordado quando compõe um traje de cena e como a aplicação desta técnica pode representar a criação uma poética têxtil no traje. Mais especificamente, a pesquisa também pretende propor uma classificação possível das funções que o bordado pode assumir em trajes de modo geral, com aprofundamento de análise no traje de cena. Para isso, realizei um levantamento bibliográfico acerca da história e usos do bordado, partindo tanto de fontes contemporâneas quanto antigas.

Além disso, uma das questões levantadas é em que medida um processo de manual de criação artística pode influenciar no resultado da obra. Para isso, a pesquisa parte de alguns estudos de caso em que o bordado foi determinante na criação de narrativas visuais no traje de cena e finaliza com um experimento prático, onde pude observar as relações que o trabalho artesanal é capaz de criar quando aliado ao texto cênico.

Em um aspecto individual, muitos criadores têm seu jeito próprio de trabalhar com os têxteis e com o bordado, conferindo novos significados aos figurinos. O critério de escolha nesta pesquisa foi partir da obra do artista Arthur Bispo do Rosário (1909-1989) e analisar trajes de cena que tivessem sido inspirados nele de algum modo. Sua obra é marcada principalmente pela ressignificação de objetos do cotidiano. Bispo do Rosário criou suas obras onde passou quase toda a sua vida adulta: no centro psiquiátrico Colônia Juliano Moreira, no Rio de Janeiro. Todas as suas criações saíram desse universo e partiram de materiais que tinha a sua disposição. 
Foi partindo desse universo que Claudio Tovar criou os figurinos do primeiro caso estudado: o musical O homem de la mancha (2014), de Miguel Falabella.

A ação se passa num manicômio no fim dos anos 1930, onde um paciente, que se apresenta como Miguel de Cervantes, buscando minimizar a dura realidade do ambiente em que se encontra, propõe aos outros internos e aos funcionários que deem um mergulho no universo do fantástico e do teatro. A peça mostra uma busca de reimaginação do cotidiano através do sonho. Os bordados de Bispo do Rosário foram trazidos para os figurinos, que contavam com imagens populares, como santos e medalhas, e com frases e palavras bordadas. Os figurinos também se propunham a um acúmulo de materiais, como retalhos, fitas e rendas, compondo uma imagem semelhante àquela das obras do artista. O cenário também contava com referências às obras de Bispo do Rosário, principalmente aos textos bordados, encontrados em muitas obras suas.

O segundo caso estudado não se debruça sobre um espetáculo, mas sim sobre o processo criativo de um encenador que já admitiu muitas vezes ter em Bispo uma figura inspiradora: Gabriel Villela. Villela trabalha muito com influências dos costumes populares em suas criações e seu cuidado com o figurino como parte integrante da composição da própria personagem é referência na cena teatral. No que diz respeito aos usos do bordado, a responsável pelas criações nas peças de Gabriel Villela é quase sempre sua irmã, Giovanna Vilela, reforçando a hipótese da ligação do bordado com o conhecimento transmitido de modo familiar. Seu trabalho é quase todo manual e remete muito à tradição do artesanato mineiro e à noção de patrimônio imaterial em que o bordado se encaixa.

Por entender que apenas a reflexão teórica não seria suficiente para estudar os usos do bordado, optei também por realizar um exercício prático de criação que envolvesse os aspectos levantados na pesquisa. Para isso, foi escolhida a peça A mulher como campo de batalha (1996) como ponto de partida para as discussões e experimentações propostas na pesquisa. Isso se deu por ser esta uma obra contemporânea, que aborda diversos assuntos ligados a papéis de gênero. Ficou claro que ao propor estudos sobre o bordado, seria necessário partir de temáticas que estivessem ligadas à condição da mulher, já que as artes têxteis foram ao longo do tempo frequentemente associadas e produzidas por mulheres. Em A mulher como campo de batalha, há não só a discussão da situação da mulher em contextos de guerra, como também no cotidiano, levantando tópicos como a violência de gênero e a posição da mulher na sociedade. Outro motivo que levou à escolha dessa peça é como se dá o seu desenvolvimento: duas mulheres conversando e evocando suas memórias para criar uma narrativa que busque racionalizar o 
horror da guerra. Como o trabalho do bordado se desenvolve no coletivo e tem íntima relação com a memória e a construção de narrativas, pareceu adequado que se pensasse as duas questões em paralelo.

A partir destes processos, elaborei o presente documento-síntese, dividido em:

- Capítulo 1: na primeira parte, me dediquei a esboçar uma breve história dos usos do bordado nos trajes. Aqui não me dediquei apenas ao traje de cena, mas também a outras categorias de trajes, tomando como base a classificação proposta por Fausto Viana (2017). O objetivo é esboçar possíveis usos narrativos do bordado quando aplicado na construção de trajes de cena.

- Capítulo 2: nesta segunda parte, se encontram alguns estudos de caso e a análise de obras em que o bordado foi elemento importante na construção dos trajes de cena. Optei por analisar obras cujos trajes foram inspirados nas criações de Arthur Bispo do Rosário, artista que produziu muitas obras têxteis em que o bordado era parte muito importante. Há uma análise dos trajes de O homem de la mancha (2014) e de alguns trajes criados pelo encenador Gabriel Villela, além de uma análise de seu processo de criação. O capítulo é concluído com alguns apontamentos que versam sobre a criação de uma poética têxtil a partir da artesania e, principalmente, do bordado.

- Capítulo 3: nesta terceira parte, exponho o processo de um exercício de criação de trajes de cena usando o bordado como elemento de destaque e analiso seus resultados. O exercício foi realizado com alunos do curso de Têxtil e Moda da EACH-USP em 2017 e tomou como ponto de partida a peça $A$ mulher como campo de batalha, de Matéi Visniec. O experimento foca em potenciais usos do bordado e prioriza a criação coletiva.

- Conclusão: Como fechamento da pesquisa, relaciono o bordado e as artes cênicas com três princípios: artesania, narrativas e narrativas visuais.

Espero que esta pesquisa possa auxiliar os interessados em bordado e artesania e contribuir para as pesquisas em traje de cena, principalmente àquelas que se interessam pelos processos de feitura dos trajes e os significados que eles podem imprimir ao resultado. 
Capítulo 1

Uma breve história dos usos do bordado 


\subsection{Os usos do bordado}

O bordado é uma das técnicas mais antigas para adornar um traje. Segundo o Centro Nacional de Folclore e Cultura Popular, o bordado é uma "técnica artesanal que consiste em atividade manual à base de linha, fio de lã, de prata, de ouro, etc., sobre estofo ou pano" ${ }^{1}$. Este é, talvez, um dos aspectos mais particulares da técnica: desde os registros mais antigos envolvendo bordado, não parece ter havido grandes transformações na sua execução.

Sennett (2009) diz que a mão, dentre todas as partes do corpo humano, é a que detém o maior número de movimentos possíveis, principalmente movimentos controlados conscientemente. A mão, por ser capaz de obedecer às vontades do homem, demonstra para o autor uma ligação evidente: mãos e cérebro devem ser ligados. O artífice é aquele que tem uma mão inteligente e no bordado isso parece particularmente verdadeiro. O bordado é uma técnica que, quão mais tempo for praticada, mais naturalmente será executada. É uma imagem comum e milenar a bordadeira que realiza trabalhos de alta complexidade com rapidez, sem sequer olhar para o trabalho. Suas mãos têm uma inteligência própria.

O trabalho manual têxtil, especificamente os diferentes tipos possíveis de bordado, é encontrado em muitos lugares do mundo e em diversos períodos; no entanto, traçar um percurso histórico da técnica não é uma tarefa simples. Uma das fontes mais antigas encontradas, o livro The Development of Embroidery in America (1921), de Candace Wheeler, fornece uma possível explicação do porquê há pouco material aprofundado sobre a técnica. Para Wheeler (1921) isso se dá principalmente devido ao seu caráter doméstico. Por não ser considerada uma prática ligada ao lucro e ao comercial, o bordado teria sido deixado de lado nos livros de história. "Os têxteis são a irmã invisível da arte" (PRAIN, 2014, p. 16).

Felizmente, ainda segundo Wheeler (1921), as artes têxteis guardam em si mesmas algumas informações históricas. A partir da própria obra, dos desenhos que ela ostenta e dos materiais que a compõe, se podem auferir muitos dados: o status de quem bordou, as condições financeiras, os hábitos cotidianos, os símbolos mais frequentes, os indícios religiosos e, até mesmo, as condições pessoais daquele que executou a obra.

Além disso, por muito tempo o bordado esteve mais ligado ao conhecimento oral que aos registros escritos. Com isso, não só muitas informações potenciais sobre a história se perderam, como também se tornaram pouco estáticas as características do bordado desses

\footnotetext{
${ }^{1}$ Disponível em: http://www.cnfep.gov.br/tesauro/00000948.htm> Acesso em 26 Set.2018.

O Centro Nacional de Folclore e Cultura Popular (CNFCP) é a referência para toas as definições de técnicas artesanais citadas neste trabalho.
} 
primeiros momentos históricos, já que a troca entre povos era muito grande. Segundo Prain (2011):

Em muitas culturas, bordadeiras eram ensinadas a bordar através da instrução oral, e esse conhecimento passou de uma pessoa a outra de modo que as sensibilidades do desenho do bordado expandiram conforme cada cultura expandiu sua esfera de influência. (PRAIN, 2011, p. 27, tradução nossa)

Ainda assim, persiste a questão: como surgiu o bordado?

Não há nas fontes consultadas um consenso acerca do período preciso em que o bordado teria surgido. Atualmente, os indícios mais antigos de bordados datam por volta de 5.000 a 4.500 A.C., tendo principalmente pinturas rupestres como documento para corroborar a informação. Esta data, no entanto, pode ser eventualmente alterada diante de novas descobertas arqueológicas.

Há também fontes pictóricas e escritas entre egípcios e outras civilizações do Oriente, como babilônios, hebreus e frígios; civilizações asiáticas das regiões da Índia e China; e entre os gregos e romanos, sendo esses últimos já influenciados pelo contato com os trabalhos vindos da Ásia e Oriente (LEFÉBURE, 2016). Porém, evidentemente, muito pouco dos materiais em si de tão longínquo momento na história sobreviveu às ações do tempo, tornando muito difícil saber com precisão se as informações deixadas refletem os usos do bordado nessas civilizações de maneira fidedigna. Por isso, ao invés de tentar traçar um percurso histórico da técnica, optouse por investigar quais os seus usos e significados ao longo do tempo e no contemporâneo.

Entende-se que os principais usos do bordado em trajes são: decorativo, identificação, ritual, narrativo e ressignificação.

\subsubsection{Decorativo}

Um dos usos mais frequentemente comentado entre as fontes levantadas é o uso decorativo. Ao longo do tempo, o bordado parece ter sido aplicado de maneira expressiva para adornar os trajes, principalmente em situações especiais ou eventos ligados a manifestações e ritos sagrados.

Há, segundo Lefébure (2016), três modos essenciais de se adornar um tecido: pintura, tapeçaria e bordado. Segundo ele, a principal diferença do bordado para as outras duas técnicas está no volume e na textura. Para dar destaque a superfícies planas, o bordado é a técnica que 
melhor atende a essa necessidade sem deixar o caráter estético de lado. Esta propriedade será muito importante quando se for pensar especificamente nos seus usos em trajes de cena.

Lefébure (2016) ainda chama a atenção para a facilidade do bordado em construir desenhos mais detalhados quando comparado com a pintura de tecido e a tapeçaria. Isso se dá tanto pela plataforma - bordar em um tecido permite mais precisão do que pintar em tecido quanto pelas ferramentas utilizadas, já que linha e agulha são mais capazes de criar elementos de dimensões menores se comparados a um pincel ou a um tear.

Sem as restrições dos inventos científicos, que fixam limites às possibilidades da máquina, a agulha, movendo-se de acordo com os caprichos e ingenuidade dos dedos que a guiam, dança com perfeita liberdade através da superfície ou da dureza de um material. Como uma caneta ou um lápis, pode traçar formas de qualquer complexidade e, em duas palavras, escrever e desenhar. (LEFÉBURE, 2016, 1.89, tradução nossa)

A agulha deve ter surgido da necessidade de costurar partes de tecido umas nas outras. Talvez por isso, muitas vezes se encontre a hipótese de que o bordado teria surgido como uma técnica de conserto ou costura, ou seja, tinha uma função utilitária. Dhamija (2004), ao falar sobre os usos do bordado nos trajes da Índia sugere que a origem da técnica pode estar numa costura decorativa de aplicação de couro e lã - que se transformou depois no bordado - e na necessidade de fortalecer roupas para que durassem mais tempo, já que sempre foram artigos muito preciosos.

Esta é também a teoria do A book of old embroidery (1921), organizado a pedido do museu Victoria and Albert. Segundo A.F. Kendrick (1921), o conservador responsável pelos têxteis no período, o bordado seria uma transformação natural da costura. Por utilizar os mesmos materiais e ferramentas, o bordado responderia a uma necessidade que a costura não supria: decorar e adornar. Assim como Lefébure, Kendrick também aproxima o bordado e a pintura e afirma que "escritores romanos, Virgílio e Ovídeo por exemplo, descrevem bordado por um termo que significa 'pintura com agulha'; esta é uma definição quase tão boa do bordado moderno quanto se pode encontrar" (KENDRICK, 1921).

Este uso persiste, possivelmente, como sendo o principal do bordado. Seja quando é aplicando como arte decorativa, em objetos e obras de arte, seja quando está presente em trajes, o bordado é frequentemente aplicado para criar interesse visual.

Atualmente, um dos aparecimentos deste uso que mais chama a atenção é a forte presença do bordado na alta costura. A alta costura é uma fusão entre moda e traje (MARTIN e KODA, 1995); é uma arte de fazer vestidos que envolve costura, alfaiataria e outros ofícios. 
Uma peça de alta costura dialoga com o artesanato de luxo - comumente referido como artesania - e a indústria da moda. Mais do que uma peça para ser usada cotidianamente e uma fonte de lucro para a marca, a alta costura é sobre mostrar ao mundo os ideias e valores da marca e demonstrar o virtuosismo técnico dos profissionais envolvidos. É uma moda exclusiva, feita à mão e com materiais de altíssima qualidade.

A alta costura não pode existir com uma equipe pequena. Sob a liderança de um estilista, trabalham muitas pessoas, atentando a cada detalhe do traje, construindo-o parte a parte. São chamados petit mains (pequenas mãos) os profissionais que trabalham nas oficinas produzindo bordados e aplicações para trajes de alta costura. Desde minuciosos desenhos em pedraria e bordado livre até delicadas flores recortadas em seda, são nessas oficinas que nascem os detalhes artesanais que comporão o traje final. E é um trabalho que pouco mudou desde sua criação. O fornissieur mais tradicional de bordados é a Maison Lesage, que desde 1924 trabalha com bordados para alta-costura.

Para Martin e Koda (1995), o que distingue uma peça de alta costura do ready-to-wear é o trabalho manual como característica intrínseca do traje. Os bordados de uma peça de alta costura, para eles, não são meros adornos que finalizam um traje, mas sim os propiciadores de seus princípios, elementos de criação que são a matriz do processo de design. Apesar do luxo não ser necessariamente o norteador do trabalho manual na moda, é inegável que o bordado foi e é utilizado para acrescer opulência nos trajes da alta costura.

Figura 1 - Casaco de noite Elsa Schiaparelli com bordados Maison Lesage (1937).

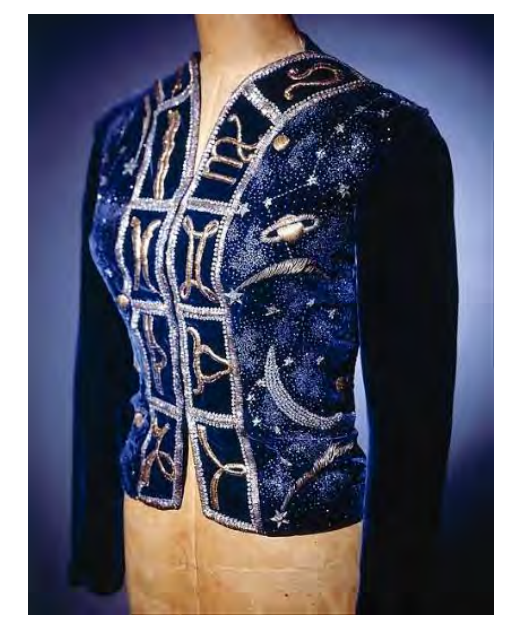

Fonte: Metropolitan Museum of $\mathrm{Art}^{2}$

\footnotetext{
${ }^{2}$ Disponível em: <https://www.metmuseum.org/art/collection/search/156060>. Acesso em 12 Dez.2017.
} 
No entanto, apesar de todo o histórico dos trabalhos artesanais e da permanência da altacostura, as oficinas especializadas em bordados manuais e os artesãos da moda estão diminuindo. As razões são bastante conhecidas: além de um mercado muito exclusivo e caro como o da alta costura (ou da demi-couture, como se chamam as criações de luxo que não se enquadram em todas as categorias necessárias para ser consideradas haute couture) não ter um público tão amplo assim, os artesãos estão morrendo e as novas gerações nem sempre se interessam pelos ofícios. Esse é um trabalho que ainda conserva muito do seu caráter familiar. Se os filhos dos bordadores não optam por seguir a carreira dos pais, dificilmente a oficina se manterá. Além disso, há, obviamente, os trabalhos industriais de bordado em pedrarias e trajes de festa, que mimetizam dos trabalhos artesanais e são muito mais baratos de produzir e comprar, ainda que normalmente sejam produzidos em locais onde as condições de trabalho e pagamento dos artesãos são pouco justas.

\subsubsection{Identificação}

Outro uso que aparece com bastante frequência é o da identificação. Há documentos atestando ser comum que determinados grupos sociais ou políticos de diversos povo ao longo da história utilizassem o bordado para adicionar detalhes, texturas, cores, etc. nos trajes que os identificariam imediatamente, para gratificar com marcas de distintivos o traje de um chefe (LEFÉBURE, 2016), por exemplo.

Nos dias atuais, o aparecimento mais comumente evocado quando se fala em identificação é o dos uniformes. É comum que se encontrem bordados com nomes, patentes, profissões e outras informações acerca do indivíduo usando o traje. Nos trajes militares, esta função é muito presente e será mais detalhada no subitem 1.2.1.

A identificação, no entanto, não precisa estar necessariamente ligada a elementos tão concretos. Por vezes, se é capaz de identificar a partir de um conhecimento comum de uma sociedade: determinada cor que só poderia ser utilizada por membros da realeza, um desenho bordado que indica a qual família o usuário da peça pertence, entre outros.

Outra maneira de identificação é a partir dos tipos de trabalho têxteis mais comuns de determinado período histórico. Segundo Watt (2010), por exemplo, os séculos XVI e XVII na Inglaterra foram frutíferos para os usos seculares do bordado. Se durante a Idade Média a maioria dos artesãos ingleses trabalharam bordando trajes da Igreja Católica, com o governo de Henrique VIII, no século XVI, tudo muda. O rompimento do rei com a Igreja Católica e 
subsequente fundação da Igreja Anglicana diminuiu sobremaneira a demanda por trajes religiosos como vistos até então no Reino Unido. Esses artesãos precisavam encontrar trabalho e sustento em outros meios.

No governo de Elizabeth I, um período de prosperidade para a Inglaterra, a nobreza fez de seus bens e trajes amostra de seu poder aquisitivo crescente. O gosto por elementos decorativos elaborados e trajes muito trabalhados fez com que o bordado ganhasse cada vez mais espaço durante esse momento. Foi também durante o governo da Rainha Elizabeth I que surgiu a Worshipful Company of Broderers, em 1561. Era uma associação exclusiva para homens que trabalhavam com bordado no período.

Como o bordado era muito popular e largamente realizado pelas diferentes camadas sociais (WATT, 2010), é muito comum encontrar nesse período livros ensinando técnicas e propondo motivos e gráficos para bordar. Os temas bordados eram os mais variados. É possível encontrar desde preocupações contemporâneas, como a monarquia e as relações sociais, até expressões das relações familiares, da natureza, da fé, etc. O que parece mais comum, no entanto, são dois grandes tipos de motivos: os baseados na fauna e flora e os bordados figurativos, principalmente ligados a passagens da Bíblia.

Ainda que a Igreja Anglicana condenasse a idolatria a imagens, rejeitando o fortalecimento à imagem de santos, os bordados figurativos bíblicos eram comuns. Principalmente as parábolas do Antigo Testamento eram consideradas de valor didático. Aliás, os temas educativos ou de alguma forma simbólicos para passar alguma mensagem eram bastante comuns. Além de cenas bíblicas, também se pode encontrar bordados sobre temas abstratos como "a virtude", "a fidelidade", etc. Muitas vezes esses motivos eram elaborados em forma de imagens figurativas e alegóricas, rodeadas de elementos com significados específicos. Esse tipo de bordado, porém, era mais popular para usos decorativos em objetos da casa.

As imagens botânicas são os elementos mais comuns dos trajes do período elisabetano. Além da forte presença de flores de diversos tipos, há também frutas e pequenos animais, como insetos e pássaros, bordados nos trajes (Figura 2). Esse foi também um período de muito estudo da natureza, portanto havia um bom número de publicações científicas dedicados à botânica. Esse material, somado às publicações específicas de gráficos de bordado, serviam de inspiração para os artesãos na hora de bordar trajes. Além disso, a jardinagem era um hábito muito apreciado. Os jardins das casas nobres se tornavam elaborados e cheios de flores de diversos lugares do mundo. 
Figura 2 - Detalhe de bordado botânico de traje elisabetano

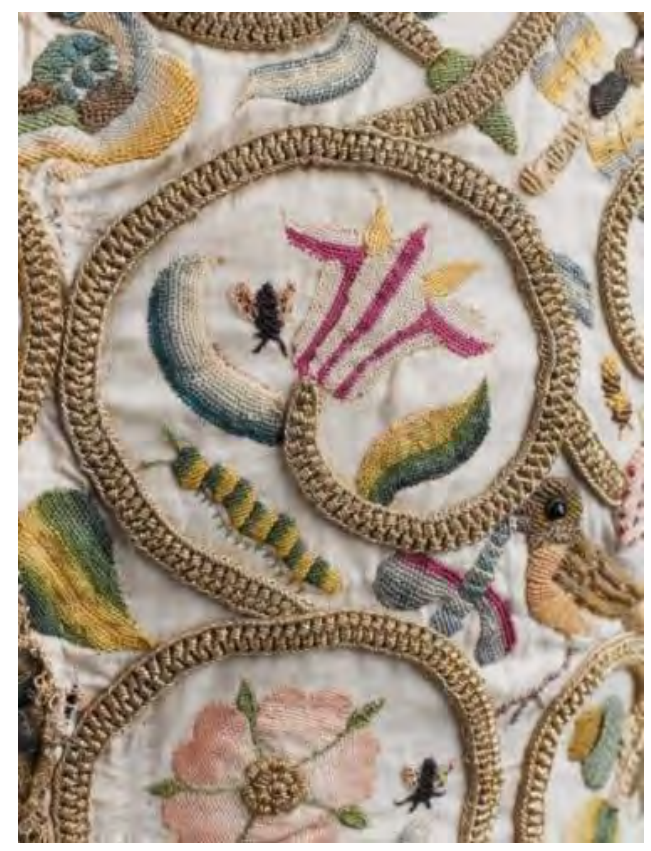

Fonte: V\&A Museum ${ }^{3}$

A partir destas características do bordado pode-se auferir informações sobre os trajes em que se encontram e identificar uma série de informações: quem utilizou, em que época, em que região, entre outras. Assim, ainda que não haja nada escrito ou nenhum símbolo evidente no traje, o modo como a técnica foi aplicada pode ser também uma maneira de identificar; neste caso, identificar historicamente.

\subsubsection{Ritual}

Para Paine (2010), é provável que o bordado primitivo fosse uma transferência daquilo que estava na pele para o tecido. Se antes o homem se tatuava para se proteger dos espíritos e dos deuses vingativos, quando passa a usar roupas - deixando o corpo e as proteções cobertas - reproduz no tecido os símbolos sagrados. Os padrões de tatuagens de diversos povos podem ser encontrados também nos bordados, o que fortalece a hipótese. A autora comenta também uma citação de Marco Polo que diz que a tatuagem é o "bordado na carne". Essa proximidade entre ambos aparece também na própria ferramenta. As duas atividades são realizadas com uma agulha: a tatuagem furando a pele para depositar a tinta e o bordado furando o tecido e entrelaçando uma linha.

\footnotetext{
${ }^{3}$ Disponível em: <https:/www.metmuseum.org/toah/works-of-art/23.170.1/>. Acesso em 05 Jan.2018.
} 
Leslie (2007) confirma essa afirmação e também descreve como potencial surgimento do bordado a tatuagem:

O ancestral das decorações simbólicas nos trajes e objetos pessoais pode ser a tatuagem. A migração de povos pré-históricos para climas mais frios necessitava de coberturas de pele tingida e couro. O bordado começou quando pontos básicos usados em costura simples começaram a ser usados para replicar padrões de tatuagens em linha. Com o passar do tempo, os motivos vinham para comunicar a identidade de um indivíduo ou grupo. Bordado foi e continua sendo um modo de adornar bem como de expressas status político, econômico e social. (LESLIE, 2007, p. 78, tradução nossa)

O potencial caráter mágico do bordado nos trajes é uma referência comum em outros momentos da história, indicando que esse aspecto ritual descrito por Paine (2010) e Leslie (2007) se manteve. Em relatos de batalhas, por vezes aparecem referências a bordados como forma de proteção nas armaduras dos soldados:

Soldados gregos usavam túnicas bordadas como uma forma de armadura. A crônica
da Batalha de Maratona ( 490 A.C.) fala de soldados persas vestindo armaduras de
retalhos costurados. A efetividade dos retalhos na batalha não era apenas por conta da
grossura do traje, mas possivelmente porque costurar ou reconstruir trajes sempre foi
associado a uma magia poderosa, a medicamentos, a dervixes ${ }^{4}$ vagantes e xamãs. O
uso de retalhos como oferenda em lugares sagrados a árvores da vida ou santuários, é
praticado ao redor do mundo. (...) Havia também os Casacos Talismã, que eram
bordados com fórmulas mágicas. (DHAMIJA, 2004, 1. 82, tradução nossa)

O uso ritual do bordado não tem apenas relação com a religiosidade, mas também com a cultura de um povo - ainda que muitas vezes ambas as instâncias se misturem sobremaneira. O Rushnyk $k^{5}$, por exemplo, bordado tradicional ucraniano, é uma espécie de tecido ritual no qual se bordam símbolos e criptogramas (Figura 2). Cada região tem seus motivos e desenhos próprios, com significados que são passados ao longo do tempo para as gerações. Esse tecido tem formato retangular para representar a vida do seu dono e os bordados trazem resquícios de uma memória ancestral, majoritariamente usando linhas vermelha azul e preta - cada uma simbolizando respectivamente o homem, a mulher e a terra. Os símbolos bordados têm cada um seu significado: cada tipo de flor significa um traço de personalidade diferente; cada animal e motivo abstrato também. Esse pano é dado à pessoa quando nasce, aparece e é modificado em outras situações importantes da vida, como casamentos e nascimentos de filhos, e finalmente a morte. O Rushnyk da Figura 3 é uma peça funerária, feito para um soldado que morreu em batalha, visando uma boa passagem para o pós-morte. Ali estão imagens que

\footnotetext{
${ }^{4}$ Dervixes são uma espécie de "monges mulçumanos", pertencentes ao islamismo sufista. A maioria leva uma vida nômade, de privações.

${ }^{5}$ Informações disponíveis em: < https://www.artsrn.ualberta.ca/folkloreukraine/?page_id=97> Acesso em 21 Set. 2018.
} 
simbolizam força (carvalho), vigor (rosa), riqueza (veado), a partida da alma (borboleta) e a morte (cruz e túmulo). Há também a kalyna, árvore que simboliza a espera e a cura, frequentemente utilizada para simbolizar soldados que foram mortos em batalha.

Figura 3 - Exemplo de Rushnyk.

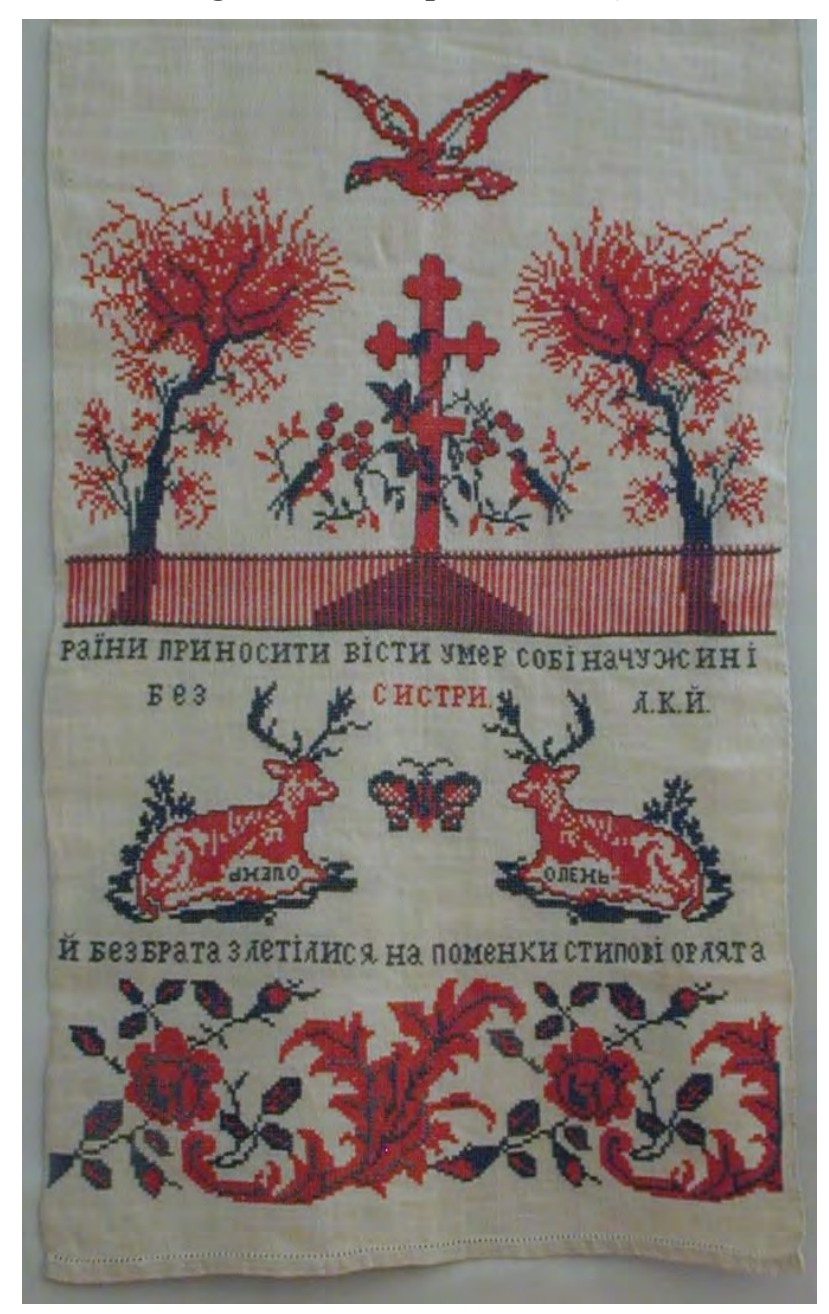

Fonte: Site Artsrn ${ }^{6}$

Ainda sobre as culturas do leste europeu, Kelly (1996) argumenta, ao investigar os tecidos e bordados rituais russos, que "o poder espiritual do tecido ritual demandava que os símbolos fossem usados corretamente, seus significados criados especificamente para seu propósito" (p.166). Especificamente sobre os trajes rituais femininos, Kelly (1996) diz que há quatro grandes grupos de símbolos comuns da cultura russa: motivos de proteção; motivos de identificação; motivos de fertilidade, tanto dos humanos como dos campos; e motivos que expressavam boas expectativas ou contratos nas relações sociais. Em grande parte da bibliografia consultada acerca dos aspectos rituais do bordado estas questões parecem se repetir.

\footnotetext{
${ }^{6}$ Disponível em: $<$ http://www.artsrn.ualberta.ca/folkloreukraine/?page_id=97> Acesso em 25 Set.2018.
} 
Entende-se que são algumas das preocupações mais básicas dos agrupamentos humanos desde tempos remotos e, portanto, seu aparecimento é frequente. Estes quatro usos são respectivamente exemplificados por Kelly (1996):

Bordar uma deusa poderosa em um tecido, elas acreditavam, protegeria o recémnascido enrolado nele de doenças. (p. 167)

O bordado indicava a posição social de uma mulher, sua vila, sua idade, e seu status marital e maternal. (p.167)

(...) o traje funerário era bordado com cabelo humano para a proteção na vida após a morte. (p. 168)

As camisas das noivas eram cobertas com motivos de fertilidade dos campos, enquanto as camisas de mulheres grávidas eram bordadas com deusas grávidas da fertilidade para assegurar um parto seguro à nova criança. (p. 169)

(...) nas cerimônias de casamento russas, o contrato de matrimônio era ratificado pela troca de uma toalha bordada. O casal era "unido" em matrimônio por um tecido literalmente unindo suas mãos. (p.170)

Além dos motivos, a posição em que os bordados se encontram também é importante. Ainda segundo Kelly (1996):

De certo modo, a ancestral camisa de linho branco eslava utilizada igualmente por homens, mulheres e crianças era como uma pele, um alter-ego que os separava da nãoexistência. Ornamentada como era no pescoço, pulsos e barras - em suma, em todas as aberturas através das quais o mal poderia atacar o corpo - a camisa se tornou tanto uma pele protetora quanto um identificador da pessoa. Pessoas em todos os países eslavos acreditavam que elas precisavam ser enterradas em suas camisas, particularmente suas camisas de casamento, para que fossem reconhecidas pela família e parentes, para "serem reconhecidos como seres humanos no próximo mundo" (Mihailova, 36). Colocar uma camisa branca "protegida" pela linha vermelha em um bebê recém-nascido também o identificava como humano; apenas após isto a criança poderia ser chamada por seu nome. (KELLY, 1996, p.167)

Esta afirmação entra em consonância com outros dados encontrados até então nesta pesquisa. Aparentemente, os dados apresentados por Kelly (1996) corroboram a teoria de Paine (2010) acerca do surgimento do bordado e sua relação com a própria pele. Além disso, ela expressa uma questão que se fará presente ao longo de toda esta pesquisa: não parece possível afirmar que o bordado seja usado apenas com um único propósito. Na maior parte das vezes o que parece ocorrer é uma mistura dos usos com diferentes objetivos: um bordado pode ser decorativo e ritual, assim como pode ser decorativo e narrativo e diversas outras combinações. O que se pode presumir é que, por vezes, algum traço possa ser predominante ou mais importante que outros. 


\subsubsection{Narrativo}

Entende-se que um bordado narrativo é aquele que conta uma história, de maneira verbal ou não. Quando presente em um traje, um bordado pode trazer informações e produzir narrativas tanto concretamente, ou seja, na escolha dos motivos bordados, quanto de modo abstrato, ou seja, nos processos de criação e recepção do bordado. Quanto àquilo que está materialmente realizado no traje, o bordado pode narrar de maneira pictórica ou simbólica.

Uma narrativa bordada realizada de maneira pictórica é aquela que mais se aproxima da nossa concepção dessa palavra. Ela espelha o movimento das narrativas verbais e coloca uma série de imagens em sequência de modo que, quando observadas em conjunto, são capazes de contar uma história a partir da sucessão de fatos. Além disso, na maior parte das vezes são imagens figurativas, que mimetizam as personagens da história contada ou, pelo menos, utilizam símbolos de fácil reconhecimento ou de histórias populares. Esses fatos podem estar dispostos de maneira linear, um ao lado do outro, formando uma sequência, ou de maneira circular, como num quadro de Bosch ${ }^{7}$, em que diversas imagens se apresentam dispersas e o olhar do espectador direciona e organiza as relações entre as imagens formando narrativas. Um exemplo bastante conhecido e estudado é a Tapeçaria de Bayeux ${ }^{8}$, que além de contar com imagens em sequência linear a história das batalhas, também conta com desenhos e escritos nas margens do tecido, que criam suas próprias narrativas e significados.

Durante a Idade Média o bordado era considerado uma forma de arte. Não apenas deveria demonstrar excelente execução técnica, como também ter significado. Era muito comum nesse período que se produzissem bordados que contavam histórias e narravam eventos e estes deveriam estar em consonância com o meio em que eram realizados. Um bordado de Tristão e Isolda, por exemplo, deveria ser bordado em uma colcha, e a vida de Cristo deveria ser bordada numa capa litúrgica (FREEMAN, 1968, n.p.). Na Figura 4, vê-se uma casula do século XV pertencente ao Duque de Warwick. Possui imagens bordadas da crucificação de Jesus Cristo (centro), santos católicos (abaixo) e o brasão da família a que pertencia o sacerdote (laterais).

\footnotetext{
${ }^{7}$ Hyeronimus Bosch $(1450$ - 1516) foi um pintor holandês conhecido por suas obras cheias de detalhes que versavam sobre questões religiosas como pecado, paraíso e inferno de maneira caricatural.

${ }^{8}$ A tapeçaria de Bayeux (séc. XI) é um tapete bordado de grandes dimensões que descreve a batalha de Hastings.
} 
Figura 4 - Casula (aproximadamente 1434-1446) do Duque de Warwick

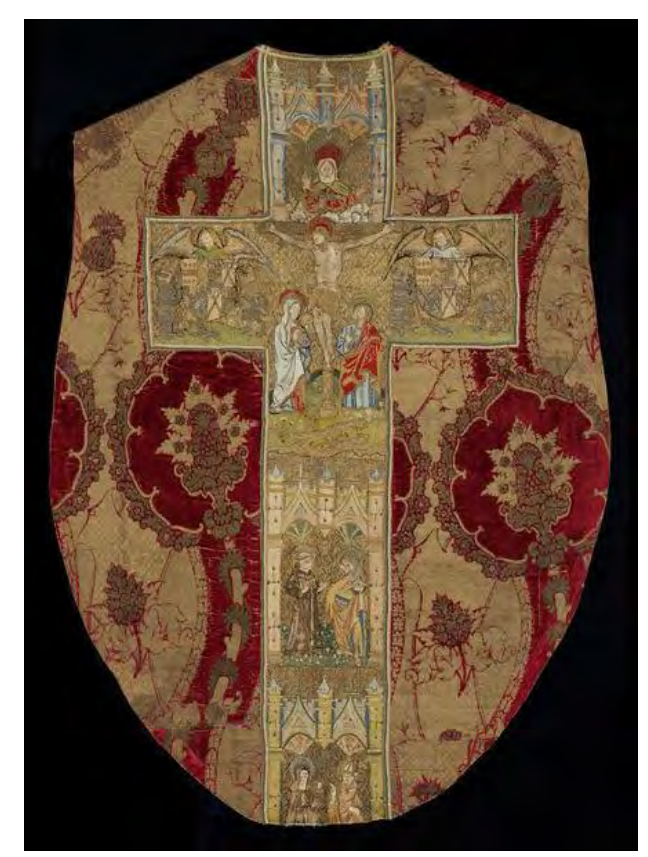

Fonte: V\&A Museum ${ }^{9}$

Este bordado pictórico, também chamado de pintura de agulha, estava no mesmo patamar que a pintura em termos de status de arte. Ele também é fortemente ligado à questão da narrativa, do contar alguma história através do trabalho têxtil. Aqui, nos interessa mais essa possibilidade de narrar visualmente um fato em um traje do que o bordado como uma das artes plásticas ou visuais.

Esse uso narrativo está longe de ser exclusividade das produções da Europa na Idade Média. Há exemplos em outras civilizações em locais distintos em que o bordado assumiu uma função narrativa pictórica, ou seja, literal. Silberstein (2016) relata no artigo Fashionable Figures: Narrative Roundels and Narrative Borders in Nineteenth-Century Han Chinese Women's Dress uma prática comum às bordadeiras da Dinastia Qing na China: bordar em trajes cenas advindas de lendas e performances artísticas. Para a autora, isso era uma maneira de fornecer às mulheres meios de se seguir as tendências de pintura e artes dramáticas da época, além de lhes ampliar a gama de possibilidades estabelecidas do que era ou não permitido estar num traje feminino (Figura 5).

\footnotetext{
${ }^{9}$ Fonte: $<$ http://collections.vam.ac.uk/item/O15361/chasuble-with-orphreys-unknown/>. Acesso em 10 Dez.2017.
} 
Figura 5 - Detalhe de jaqueta feminina chinesa do séc. XIX.

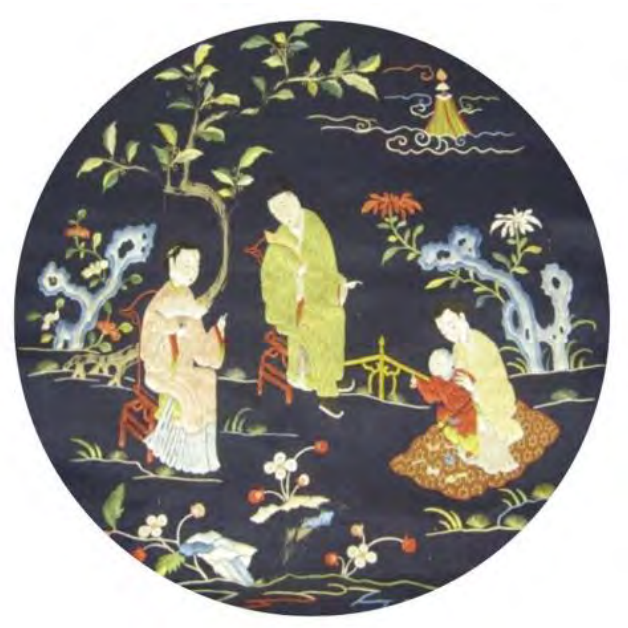

Fonte: Royal Ontario Museum ${ }^{10}$

O uso narrativo simbólico utiliza elementos para contar a história que não representam necessariamente de maneira mimética as personagens da história. Normalmente, esse tipo de uso está ligado à cultura tradicional, ou seja, faz parte de um campo de referências de determinado povo e é facilmente reconhecido por todos aqueles que partilham da mesma vivência ou cultura. Há diversos exemplos de trajes que contém uma narrativa interna, ainda que não exiba imagens que reproduzem cenas e fatos. Esse uso narrativo utiliza elementos para contar histórias que não representam de maneira mimética as personagens e costuma estar ligado às culturas tradicionais. É por exemplo, uma tradição da região de Punjab, na Índia, que ao casar a noiva receba de presente da família do noivo um traje chamado Vari-da-Bagh (Figura 6). Essa peça começa a ser bordada desde o nascimento e pode representar a história da família:

Através da introdução de uma cor, uma mudança no padrão, pode-se indicar o ritmo da vida. A cor amarela ouro do bordado pode de repente conter um ponto negro, para guardá-lo do olho mau; azul escuro, grava a morte de alguém; um quadrado rosa indica a alegria de um casamento; o verde, o nascimento de uma criança. Uma mudança repentina no padrão, pode indicar a visita de uma filha querida que borda sua contribuição no Bagh da família. É esse Bagh que é enrolado em torno da noiva quando ela entra em sua casa nova. Simboliza que agora ela é parte da família e divide suas alegrias e tristezas. (DHAMIJA, 2004, 1. 76, tradução nossa)

10 Disponível em: <http://www.tandfonline.com/doi/full/10.1080/05908876.2015.1129859>. Acesso em 11 Dez.2017. 


\section{Figura 6 - Detalhe de um Vari-da-Bagh}

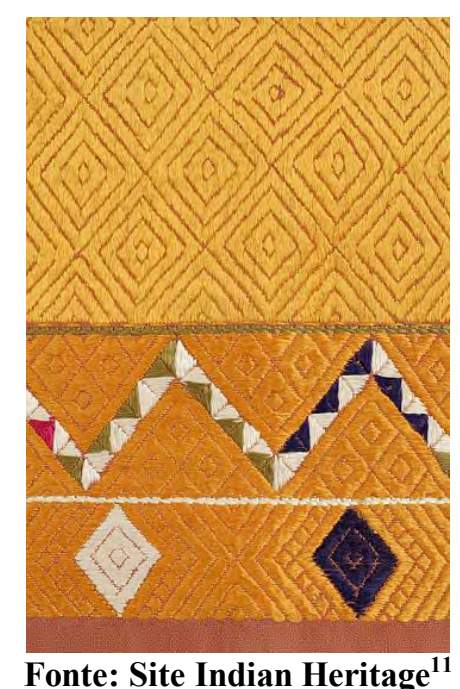

A relação do tecer - e por extensão do bordar - com o narrar parte desde a própria etimologia das palavras. Para Barthes (2010), “Texto quer dizer Tecido, acentuando deste a ideia gerativa de que o texto se faz, se trabalha através de um entrelaçamento perpétuo" (p.74).

Para além dessa questão etimológica, as duas ações se assemelham no que têm de mais concreto: seus processos. Tanto narrativas textuais quanto bordadas são trabalhos que partem de unidades mínimas para formarem um todo com significado. O ponto vai sendo executado e trabalhado pela mão humana a fim de confeccionar uma obra têxtil. A narrativa, da mesma maneira, é uma trama formada por palavras - sejam elas orais ou escritas - que vão compondo um todo. (GIL, 2017, pg. 245).

Outro elemento que aproxima o bordar e o narrar é o fato de que ambos são "forma artesanal de comunicação" (BENJAMIN, 1994, p.205). O narrar se constrói com diversas camadas de significado, que vão sendo acumuladas ao longo tempo pelo narrador e que vão construindo um produto que nunca estará completo, seja por sempre poder ser modificado devido a novas experiências, seja por permitir sempre novas interpretações e mensagens de acordo com a relação com o ouvinte. Por isso, as histórias que mais facilmente eram memorizadas eram aquelas em que o narrador renunciava às "sutilezas psicológicas" (idem, 1994, p.204), permitindo ao ouvinte que associasse a história a sua própria experiência. E isso permitia que as histórias fossem também recontadas por eles próprios. Aquele que um dia foi o ouvinte podia se tornar também o narrador.

\footnotetext{
${ }^{11}$ Disponível em: <http://www.indianheritage.biz/Phulkari.html>. Acesso em 11 Dez.2017.
} 
enquanto ouve a história. Quanto mais o ouvinte se esquece de si mesmo, mais profundamente se grava nele o que é ouvido. Quando o ritmo do trabalho se apodera dele, ele escuta as histórias de tal maneira que adquire espontaneamente o dom de narrá-las. Assim se teceu a rede em que está guardado o dom narrativo. E assim essa rede se desfaz hoje por todos os lados, depois de ter sido tecida, há milênios, em torno das mais antigas formas de trabalho manual.” (BENJAMIN,1994, p. 205)

É por isso que, numa sociedade mercantil, a narração vai perdendo espaço. Ela exige tempo e experiência pessoal, elementos que vão se perdendo num mundo moderno. Prain (2011) reforça que "o cuidado e atenção que o bordado requer, demandam que se dê a ele o bem mais valioso do mundo: tempo" (p.18). Talvez por esta razão, trabalhos manuais perderam espaço numa sociedade que visa o lucro. Eles não atendem às demandas de produção. Um trabalho manual leva um tempo maior para ser realizado; possivelmente por isso, a relação que se estabelece com um produto manual é diferente da com um trabalho feito pela máquina: existe uma história por trás de todo trabalho manual. Quais foram as experiências que levaram àquele resultado? Qual a tradição expressa numa obra realizada manualmente?

Há muitas obras que versam sobre a preservação das histórias pessoais através do trabalho têxtil e do bordado. Por ser um conhecimento passado através das gerações, o bordado se torna patrimônio imaterial de muitos povos e é através deles que se encontram maneiras de preservar a memória de famílias e culturas. Esta preservação é, também, uma forma de narrar através dos têxteis e do bordado - anteriormente referida como abstrata. São apresentados alguns exemplos abaixo a fim de que fique claro a extensão da relação do bordado com a memória em diferentes povos:

Para imigrantes italianos e seus descendentes, o bordado representa um marcador de identidade, um marcador cultural tão poderoso quanto a massa e a música napolitana. (...) O bordado, portanto, funciona como um artefato da imaginação, um repositório de sonhos, esperanças, desapontamentos, desejos. É material para o trabalho da memória. (GIUNTA, Edvige e SCIORRA, Joseph. Embroidered stories: interpreting women's domestic needlework from the Italian Diaspora. Jackson: University Press of Mississippi, 2014.p. 4, tradução nossa)

Mulheres palestinas se uniram por gerações com suas filhas para trabalhar de maneira coletiva em projetos de bordado, se ligando umas às outras através da contação de histórias e xícaras de chá. Foi assim que minha mãe aprendeu bordado, e foi assim que eu aprendi bordado. (GHNAIM, Wafa. Tatreez \& Tea: Embroidery and Storytelling in the Palestinian Diaspora. Nova Iorque: Wafa Ghnaim. Edição do Kindle, 2016.Locais do Kindle 86-88, tradução nossa)

(...) "para ela [mulher de Caiacó], esses bordados guardam a lembrança do jeito de praticar o ofício de bordadeira de suas tias, de seus antepassados, por isso sendo algo de muito valor, muito raro". Nesse sentido, o bordado à mão é valorizado como algo 
que remete a uma tradição, a um passado, sendo também valorizado porque se perde, se transforma. (BRITO, Thais Fernando Salves de. Bordados e bordadeiras: um estudo etnográfico sobre a produção artesanal de bordados em Caiacó/RN. 2010. Tese de doutorado. Faculdade de Filosofia, Letras e Ciências Humanas, Universidade de São Paulo, p. 119)

(...) os têxteis têm sido há muito tempo um meio para mensagens subversivas: no século XIX, sufragistas presas passavam lenços bordados umas às outras para partilhar solidariedade; no meio do século XX, a artista feminista Judy Chicago trabalhou com um time de artistas têxteis para registrar imagens de nascimentos de crianças, que foram até então deixados de lado pelos cânones da história da arte; nos anos 1970 e 80, mulheres do Chile bordaram tecidos que contavam as histórias de gerações de "desaparecidos" sob a ditadura de Pinochet. (PRAIN, Leanne. Strange Material: Storytelling through textiles. Vancouver: Arsenal Pulp Press, 2014, p. 17, tradução nossa)

\subsubsection{Ressignificação}

Um último uso possível destacado neste projeto é a ressignificação. Isto ocorre quando o bordado, ao ser aplicado em um traje, modifica seu sentido ou significado de alguma maneira. Também é possível que se pense no caminho inverso: um bordado criado para um objeto do cotidiano que é aplicado num traje e, por isso, ganha novos significados.

Ainda que o mundo se encontre hoje num momento de incentivo ao consumo e de produção acelerada na indústria da moda, o chamado Movimento Slow Fashion vem ganhando adeptos e destaque em diversos lugares do mundo. Criado em 2008 por Kate Fletcher, professora do Centre for Sustainable Fashion, o slow fashion foi inspirado no movimento slow food, que prega uma maior consciência nos produtos que são consumidos e com os quais a população se alimenta. Assim como na alimentação, é preciso se atentar aos meios de produção e distribuição das roupas e produtos ligados à moda.

A indústria da moda, ligada ao fast fashion, é ligada a uma produção em massa nem sempre realizada de maneira limpa. Para garantir preços baixos, essa indústria precisa pagar mal os funcionários e mantê-los em condições precárias de trabalho, além de fazê-los produzir em prazos muito curtos. Muitas vezes, a moda está também ligada a indústrias poluentes que prejudicam o meio ambiente. O consumo excessivo que alimenta essa indústria é prejudicial tanto para os trabalhadores quanto para a natureza. Numa tentativa de consumir de maneira mais consciente e prejudicando menos o seu entorno, muitas pessoas têm se voltado para marcas pequenas e de produção local. Essas marcas são muitas vezes ligadas à produção artesanal, buscando trabalhar com cooperativas e empresas menores de tecidos. O bordado tem sido utilizado por essas marcas também como uma forma de resistência a esse sistema. Na Figura 7 
vê-se uma peça da coleção The resistence series, da marca slow fashion Lingua Franca, sediada em Nova Iorque. A marca faz bordados manuais sobre suéteres produzidos em pequena escala.

Figura 7 - Suéter Latham Thomas.

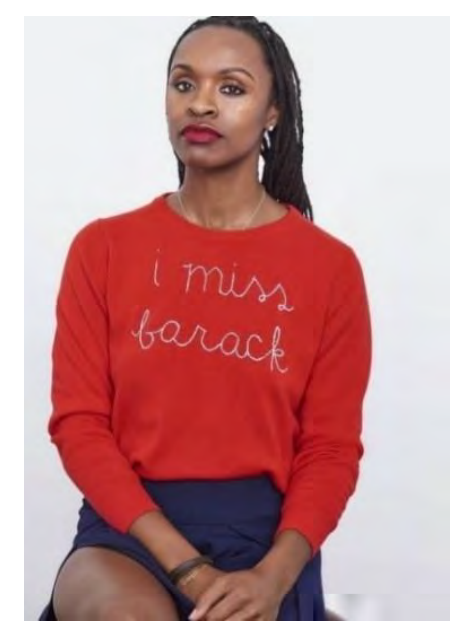

Fonte: Site da marca $^{12}$

Outra tendência que tem crescido bastante ligada ao bordado é o upcycling. Nesse processo, peças que seriam descartadas ou que já não eram mais utilizadas, ganham vida nova através de intervenções e customizações. Uma das maneiras de realizar essa revitalização de um tecido é aplicando bordados sobre ele. Ou de reciclar o bordado, aplicando-o sobre um tecido novo. Na Figura 8 vê-se uma peça de Tessa Perlow, artista que revitaliza roupas antigas, encontradas principalmente em brechós, através do bordado.

Figura 8 - 'Peça de Tessa Perlow

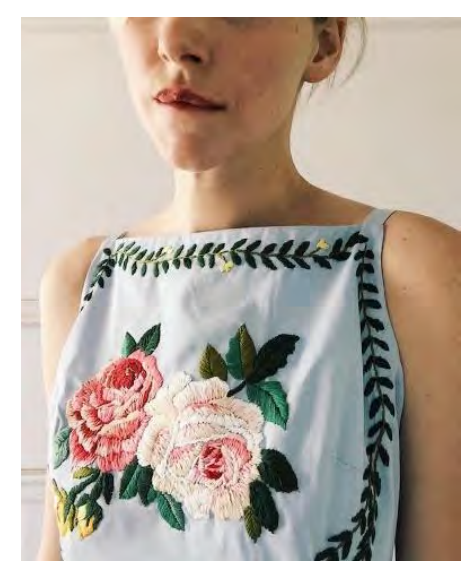

Fonte: Site Brown Paperbag ${ }^{13}$

\footnotetext{
${ }^{12}$ Disponível em: $<$ https://linguafranca.nyc/collections/the-resistance-series-pamela-hansonshoot/products/latham-thomas $>$. Acesso em 13 Dez.2017.

${ }^{13}$ Disponível em: <http://www.brwnpaperbag.com/2016/07/21/tessa-perlow/>. Acesso em 13 Dez.2017.
} 
A ideia de reaproveitamento de trajes, no entanto, já era bastante comum aos criadores de trajes de cena, seja por opção estética ou financeira.

\subsection{Usos do bordado em diferentes tipos de trajes}

Pensando nos usos principais descritos, é possível encontrar quais as principais funções assumidas pelo bordado em cada categoria de trajes. Esta divisão partirá da classificação proposta por Viana (2017) que divide os trajes em três grupos: traje militar, traje eclesiástico e traje social, sendo este último subdividido em dez tipos (traje regional, traje social, traje profissional, traje interior, traje de folguedo, traje esportivo, traje fúnebre, traje associacionista, traje etnográfico e traje de cena).

Quadro 1 - Classificação de trajes - por Fausto Viana

\begin{tabular}{l}
\hline \multicolumn{2}{c}{ QUADRO FINAL DE CLASSIFICAÇÃO DE TRAJES- PROPOSTO POR FAUSTO VIANA } \\
\hline TRAJE ECLESIÁSTICO \\
\hline TRAJE MILITAR \\
TRAJE CIVIL: \\
$\qquad$ Traje social \\
Traje de cena \\
Traje regional \\
Traje profissional \\
Traje interior \\
Traje dos folguedos \\
Traje fúnebre \\
Traje esportivo \\
Traje associacionista \\
Traje etnográfico \\
\hline
\end{tabular}

Fonte: Viana (2015), p.50. ${ }^{14}$

As principais funções que o bordado pode assumir num traje são: estética, quando o objetivo é adornar ou decorar um traje; ritual, quando ele assume um potencial mágico e/ou religioso, trazendo para o traje uma ligação com o místico e transcendente; identificação, quando nele estão contidas informações que forneçam dados tanto sobre o usuário do traje como sobre sua cultura, posição social, etc.; narrativa, sendo que esta narrativa pode estar tanto

14 Disponível em: <http://www.teses.usp.br/teses/disponiveis/100/100133/tde-16122015-125257/pt-br.php> Acesso em 21 Set.2018. 
expressa materialmente no traje quanto ser depreendida a partir do processos de criação; e ressignificação, quando o bordado modifica o significado do traje ou tem seu significado modificado por se encontrar presente em um traje. Propõe-se, assim, um quadro simplificado das principais funções que o bordado pode assumir em cada tipo de traje e que serão detalhadas ao longo do capítulo:

Quadro 2 - Proposta de usos do bordado por tipo de traje

\begin{tabular}{|c|c|c|c|c|c|c|}
\hline \multicolumn{2}{|r|}{ Tipo de Traje } & Decorativa & Ritual & Narrativa & Identificação & Ressignificação \\
\hline \multicolumn{7}{|c|}{ Militar } \\
\hline \multicolumn{7}{|c|}{ Eclesiástico } \\
\hline \multirow{10}{*}{ 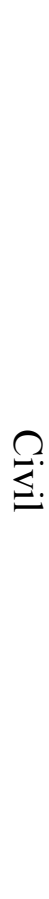 } & Social & & & & & \\
\hline & De Cena & & & & & \\
\hline & Regional & & & & & \\
\hline & Profissional & & & & & \\
\hline & Interior & & & & & \\
\hline & Dos Folguedos & & & & & \\
\hline & Fúnebre & & & & & \\
\hline & Esportivo & & & & & \\
\hline & Associacionista & & & & & \\
\hline & Etnográfico & & & & & \\
\hline
\end{tabular}

Fonte: elaborado pela autora

\subsubsection{Traje Militar}

Os trajes militares são compostos de muitos detalhes e elementos simbólicos. De modo geral, cada parte do traje tem significado próprio e precisa ser rigorosamente seguido. No Brasil, considera-se que os trajes militares podem ser do exército, da aeronáutica e da marinha, além da força espacial. Os trajes de gala militares, ou seja, aqueles que foram pensados para uso em eventos sociais, também seguem a mesma formalidade (Figura 9). Historicamente, é fácil 
pensar em exemplos de trajes militares de gala bastante decorados com bordados e aplicações. Além de decorativos, esses bordados também indicavam a procedência e patente do usuário dependendo da riqueza do material utilizado.

Figura 9 - Jaqueta militar de gala francesa do séc. XIX com detalhes bordados dourados.

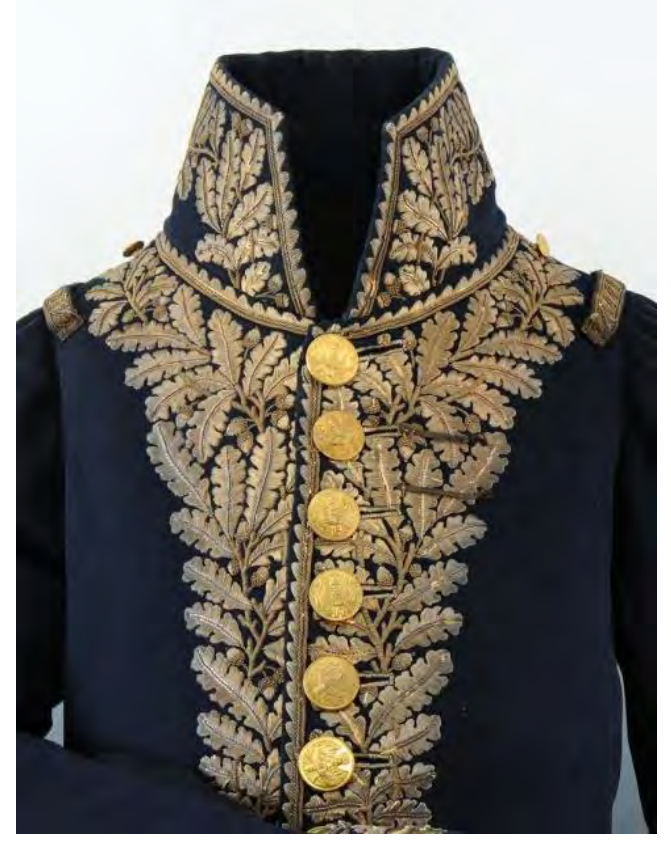

Fonte: Site Bertrand Malvaux ${ }^{15}$

Documentos oficiais regulamentam a construção dos uniformes, desde suas composições até adereços e distintivos. Além de cores, tecidos e técnicas usadas para cada um desses elementos, há também regras de posição e tamanho que cada um pode assumir.

O bordado está bastante presente na composição dos detalhes dos uniformes militares, possivelmente por conta de sua durabilidade. Ele é talvez o elemento mais transformador desse tipo de traje pois é através dele que se personaliza o uniforme, tornando-o exclusivo daquele que o usa. É muito usado numa função de identificação: pode tanto identificar o usuário do uniforme através de seu nome, tipo sanguíneo e nacionalidade, função, etc., como, através de distintivos e símbolos, indicar sua patente e agrupamento. Na Figura 10, vê-se um exemplo de bordado para aplicação em quepe da oficiais, cadetes e alunos do centro de formação da aeronáutica.

15 Disponível em: <http://www.bertrand-malvaux.com/fr/p/20877/habit-de-petit-uniforme-de-general-debrigade-au-reglement-du-1 er-vendemiaire-an-xii-24-septembre-1803-premier-empire.html>. Acesso em 14 Dez. 2017. 
Figura 10 - Patch bordado da aeronáutica.

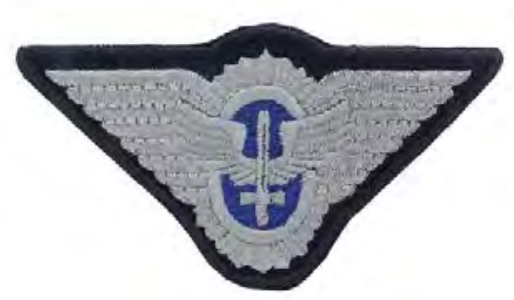

Fonte: Site Asa Artigos Militares ${ }^{16}$

Ainda que para nós esses sejam os trajes militares que mais facilmente ocorrem quando se pensa no termo, há ainda um longo histórico de armaduras nessa categoria. Usadas principalmente em combate e apresentações/jogos, as armaduras eram utilizadas como proteção, como modo de intimidar seus oponentes à distância e como ostentação da riqueza e status de seus usuários. Muitas vezes, as armaduras eram decoradas com padrões que mimetizavam os bordados dos tecidos. Era uma solução para inserir adornos nesses trajes, já que toda roupa feita em tecido ficava coberta pela camada de metal. Segundo Hayward (1959):

Pela metade do século XVI, a cor começa também a tornar-se importante na ornamentação da armadura. Porém, ao invés de usar a cor sob forma de tecido escondendo o metal, é o próprio metal que agora vem a ser tingido. As tiras verticais das ornamentações trabalhadas em relevo e gravadas são em parte douradas, em parte enegrecidas, em parte brilhantes e polidas enquanto que as superfícies assim determinadas são azuladas ao fogo. (HAYWARD, 1959, p.53)

Figura 11 - Armadura alemã de 1525, feita em aço e ouro, mimetizando tecidos adornados.

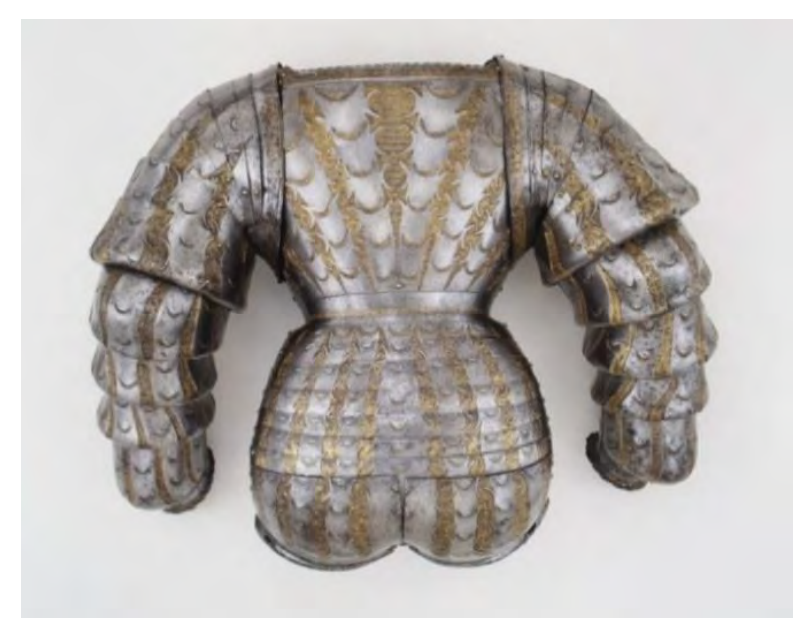

Fonte: Metropolitan Museum of Art $^{17}$

16 Disponível em: <http://www.asaartigosmilitares.com.br/aeronautica-1/cracha-bordado-para-quepe-deoficiais.phtml>. Acesso em 14 Dez. 2017.

${ }^{17}$ Disponível em: <https://www.metmuseum.org/toah/works-of-art/24.179_26.188.1,.2_29.158.363a,b/>. Acesso em 14 Dez. 2017 
Isso fazia com que a armadura ficasse trabalhada de maneira artística e exclusiva e mimetizava o requinte de um rico tecido bordado quando ostentado por um nobre ou cavaleiro de posses. Seria possível dizer que esses adornos também seriam uma espécie de bordado?

\subsubsection{Traje Eclesiástico}

O traje eclesiástico é claramente um traje ritual. É utilizado pelos sacerdotes e afins para a celebração e participações em ritos religiosos e, portanto, está investido de grande simbologia e potencial místico. Cada religião tem suas próprias regras e determinações no que tange a composição dos trajes utilizados por essas pessoas.

Nos trajes da Igreja Católica, é comum que sejam bordados nos trajes símbolos, de acordo com o tipo de traje. Por vezes também é possível encontrar nas oficinas e lojas especializadas na produção destes trajes, indicações de uso de acordo com o período do ano litúrgico. Na Figura 12, vê-se uma casula vermelha com bordados que simbolizam a cruz e o Espírito Santo. A loja indica que, por conta da cor e dos símbolos ostentados, a casula deveria ser usada no período de Pentecostes. Em alguns trajes, é possível também encontrar bordados decorativos e narrativos, mas isso varia entre os momentos históricos, usuários, regras da Igreja na época - que podiam pregar mais ou menos modéstia no vestir - etc. Ainda que, por se tratarem de trajes eclesiásticos, espera-se que os trajes contenham bordados carregados de simbolismo, nem sempre isso acontece, já que eles podem ser apenas decorativos.

Figura 12 - Casula sugerida para o período de Pentecostes.

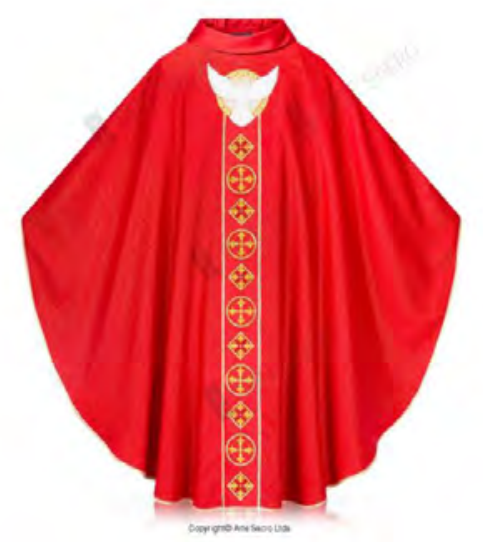

Fonte: Site Artesacro ${ }^{18}$

\footnotetext{
${ }^{18}$ Disponível em: < https://www.artesacro.com.br/casula-pentecostes-1177.html?__SID=U> Acesso em 25 Set. 2018.
} 
Mas os trajes eclesiásticos não se resumem apenas à Igreja Católica. Ainda que por vezes a expressão "eclesiástico" esteja no imaginário brasileiro muito ligada ao Catolicismo, há outras religiões que poderiam ser utilizadas como exemplo para tratar de usos rituais do bordado. Nos trajes do candomblé e da umbanda, por exemplo, pode-se adornar utilizando bordados com símbolos que remetam ao orixá que se pretende homenagear:

No pano da costa você bota pelo mais simples que seja a história do orixá que você quer homenagear (sobre bordados e simbolismos) outrora você botava a história de orixás em bordados como toda civilização antiga. Através de bordados você vai encontrar no Benin, tapetes chamados panôs, são panos feito cortina que conta a história dos reis através de imagens. (...). Por exemplo, tem pessoas que escolhem para Iansã, fazer borboletas, porque borboletas simboliza liberdade e Iansã é livre, é o vento, é o fogo, Iansã é o relâmpago, mas principalmente o vento que pode estar em todos os lugares então borboleta simboliza tudo isso. Então os temas das roupas de Candomblé dos bordados, são objetos ou coisas ligados ao orixá, Oxum você vai ver muito peixe, muitas flores. Iemanjá você vai ver, flor, peixe, concha, estrela do mar, entendeu? Geralmente os orixás que você vai mais usar bordado, roupa bordada, são as iabás que são: Iemanjá, Oxum, você pode usar pra Nanã (que não é típico). Nanã não são muitos bordados, são tecidos grosseiros, é outra história. O Orixá cada um tem uma linhagem de roupa que é da Natureza dele. Por exemplo, Oxalá você só bota branco, então tem pessoas de Oxalá que a roupa não pode colocar Seda, Tafetá, porque é brilho, não se usa, só coisas foscas. Então você faz o que? Cria o bordado para dar uma graça, uma beleza aquela roupa. Iansã são flores, borboletas. Oxum se você tiver o risco de uma cornucópia aí você coloca, o chifrinho que sai dinheiro, porque Oxum é a deusa da riqueza. (CATARINA apud NASCIMENTO, 2016, p.185)

Figura 13 - Rum de Iansã bordado com borboletas.

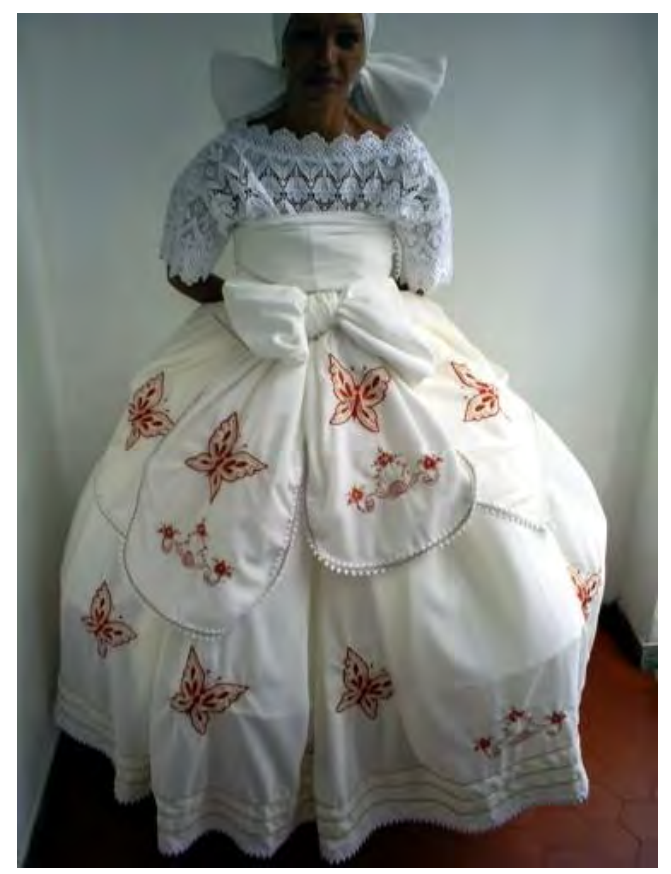

Fonte: Blog Orixás, Umbanda e Candomblé ${ }^{19}$

${ }^{19}$ Disponível em: < http://wwworixas.blogspot.com/2011/02/roupas-de-santo-candomble-ii.html $>$ Acesso em 25 Set. 2018. 
O candomblé também tem em seus trajes uma estreita relação com o bordado Richelieu $^{20}$, técnica que há mais de 200 anos é utilizada. Além do efeito visual, o Richelieu ainda guarda em si uma história ligada às origens da religião no Brasil, já que era um bordado utilizado por mulheres após a abolição da escravatura (Catarina apud Nascimento, 2016) para garantir seu sustento. O Richelieu e a bainha aberta ${ }^{21}$ parecem também, para Catarina (2016), uma solução para produzir adornos em tecidos de menor qualidade:

Esses são os primeiros bordados dos iaôs do povo do Candomblé, porque? Porque tradicionalmente, o negro não podia botar coisas de branco, então ele cria por sua própria cabeça formas de decorar sua roupa. Entendeu? Esse é um dos tipos mais simples. Então o negro cria porque ele não podia imitar o traje do colonizador. (CATARINA apud NASCIMENTO, 2016, p.184)

\subsubsection{Traje Civil}

\subsubsection{Traje regional}

Os trajes regionais são aqueles usados por populações específicas. Cada país pode ter uma infinidade de trajes regionais diferentes dependendo de sua extensão e diversidade de culturas. O bordado costuma ser um elemento decorativo bastante frequente em muitos lugares do mundo. Além disso, ele também tem função de identificação, já que documenta as condições do povo que o produziu e sua época de criação e execução, o ambiente em que foi produzido e outros referenciais ligados à região. Pode também ter função ritual e narrativa.

Portugal é um exemplo de país com grande diversidade tanto de trajes regionais quanto de trabalhos com bordados. Na Figura 14 vê-se o traje regional de Viana do Castelo, município da região do Minho. Esses trajes são de origem camponesa e daí tiram sua inspiração para os desenhos bordados, na maioria das vezes com motivos florais e muitas cores. (Silva, 2006, p.20) O mais conhecido é o bordado sobre tecido vermelho.

Também da região do Minho provêm os lenços portugueses bordados, popularmente conhecidos como lenços de namorado (Figura 15). Os lenços possuíam forte caráter narrativo e simbólico:

Os lenços estão carregados de simbolismo, são bordados pelas raparigas quase sempre a ponto de cruz, e significavam uma prova de afecto pelo rapaz com que namoravam. As composições eram realizadas ao sabor do sonho e da fantasia que se encontrava em cada uma destas raparigas. Estas guiavam-se apenas por um marcador que faziam

\footnotetext{
${ }^{20}$ Richelieu é uma técnica de bordado em que se fazem pequenos buracos no tecido e se contornam com pontos de caseado. Normalmente executado em linha branca sobre tecido branco, apresentando figuras de flores e folhas principalmente.

${ }^{21}$ A bainha aberta é um tipo de bordado feito normalmente nas barras dos tecidos. Consiste em desfiar sessões do pano e entrelaçar os fios restantes de modo a formar desenhos.
} 
previamente em mais novas, e que não era mais do que um rectângulo de pano bordado com um abecedário, alguns algarismos e alguns desenhos decorativos. A carga simbólica estava sempre presente; os bordados de corações e uma chave significavam o amor de dois corações e a chave para esse amor. (SILVA, 2006, p.24)

Figura 14 - Trajes regionais de Viana do Castelo, fotografados na Romaria da Senhora d'Agonia.

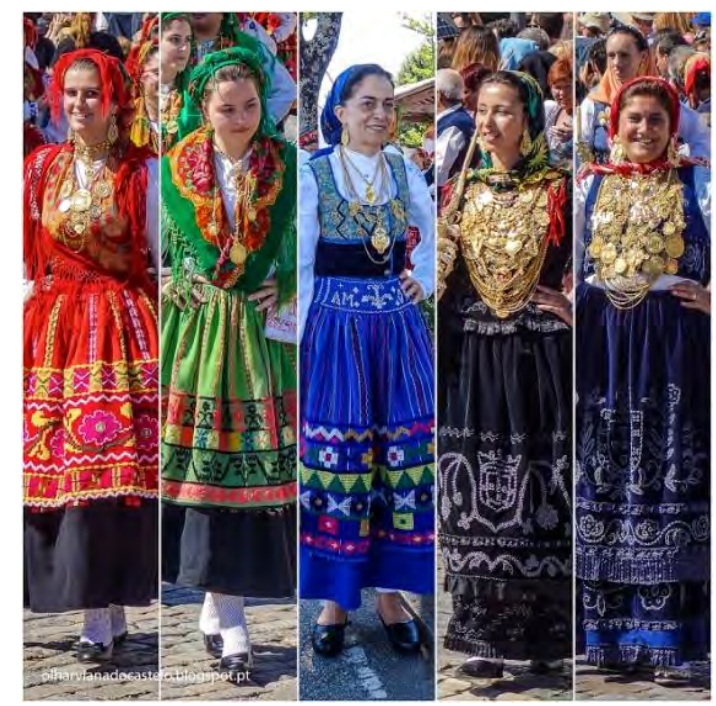

Fonte: Blog Olhar Viana do Castelo ${ }^{22}$
Figura 15 - Exemplo de lenço de namorado da região do Minho.

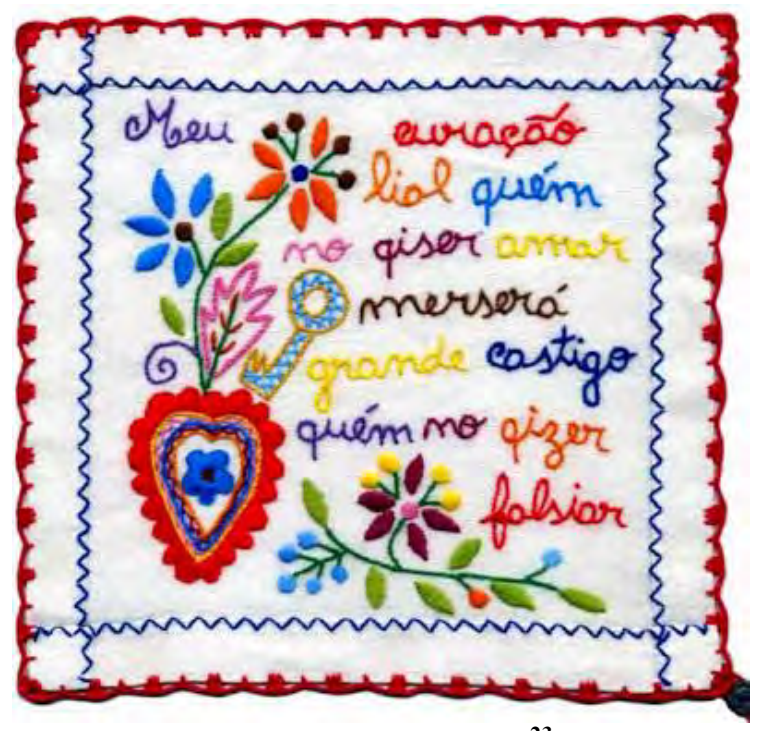

Fonte: The UniPlanet ${ }^{23}$

Ainda que os trajes regionais se mantenham em alguns locais com algumas modificações, a grande maioria já não é mais usada cotidianamente.

\subsubsection{Traje social}

A função do bordado aqui é estética. Pode aparecer tanto em trajes mais simples como mais elaborados, utilizando de diversas técnicas de bordado. É muito comum em roupas de festa, onde o bordado em pedraria é bastante popular (Figura 16). Também aparece em roupas de uso mais cotidiano, tanto à máquina quanto à mão. Pode ainda funcionar como identificação da marca da roupa, quando há o nome ou logo bordado. Muitas vezes, o ato de bordar o logo de uma marca em um local visível é também um símbolo de status (Figura 17). Pode também ressignificar uma roupa, como nos casos citados no item 1.1.3. em que se revitaliza um traje ao bordá-lo e lhes confere novas gamas de significado.

\footnotetext{
22 Disponível em: < http://olharvianadocastelo.blogspot.com.br/2016/08/trajes-tradicionais-do-concelho-deviana.html>. Acesso em 14 Dez. 2017.

${ }^{23}$ Disponível em: < https:/www.theuniplanet.com/2011/02/os-lencos-dos-namorados-do-minho.html > Acesso em 25 Set. 2018.
} 
Figura 16 - Peça da coleção Sera da Dolce \& Gabanna (S/S17).

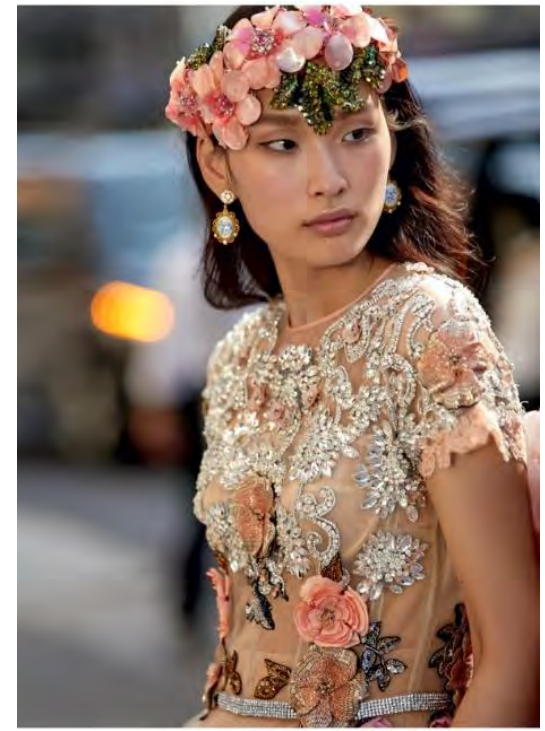

Fonte: Site Dolce \& Gabanna ${ }^{24}$
Figura 17 - Detalhe do logo bordado em uma camisa Lacoste.

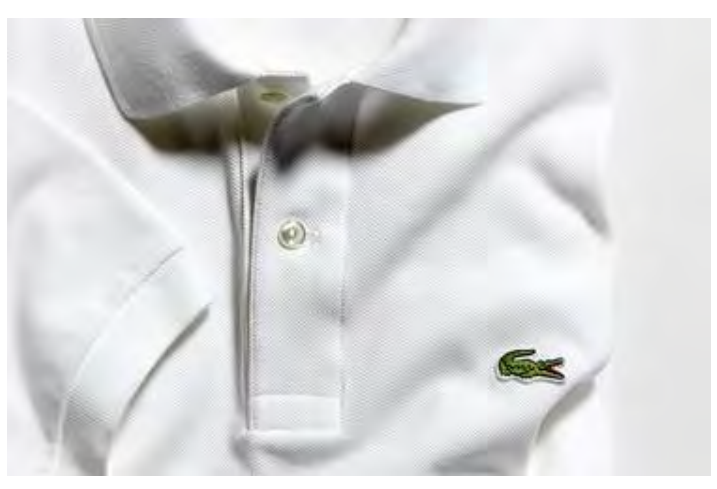

Fonte: Site Lacoste L $^{25}$

\subsubsection{Traje profissional}

Os trajes profissionais podem conter bordados com função estética, mas sua principal função é a de identificação. Normalmente, se encontram bordados nomes de usuários dos trajes, instituições às quais pertencem, nomes de empresas, logos, função exercida, entre outros. Pode aparecer em diversos locais do traje, mas o mais comum é nas mangas e peito, onde ficam bastante visíveis.

Figura 18 - Detalhe de jaleco bordado com nome, profissão e universidade do usuário

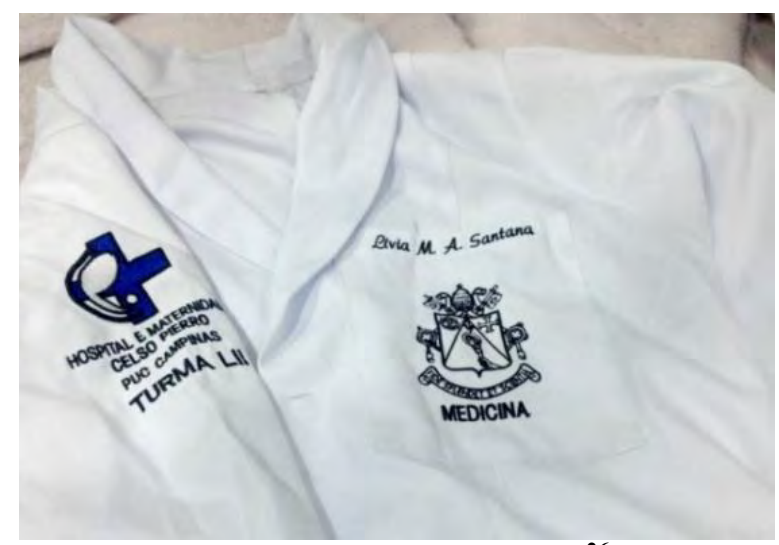

Fonte: Site Livraria UFSM ${ }^{26}$

24 Disponível em: <http://www.dolcegabbana.com/woman/collection/sera/>. Acesso em 11 Jan. 2018.

${ }^{25}$ Disponível em: <https://www.lacoste.com/pt/>. Acesso em 11 Jan. 2018.

${ }^{26}$ Disponível em: <http://livrariaufsm.com.br/grife-ufsm/jaleco-de-algod-o.html>. Acesso 11 Jan. 2018. 


\subsubsection{Traje interior}

Diz-se traje interior todo traje cuja função é ficar entre a pele e os trajes exteriores. Muitas vezes estes trajes não ficam visíveis, pois se encontram por baixo de outras camadas de tecido. Nesses casos o bordado parece ter principalmente a função de adornar. Em alguns momentos da história, esses adornos podem ter como objetivo demonstrar o luxo e riqueza de quem usa o traje.

O corset da Figura 19 é conhecido como Bon Ton. Ele data de 1876 e ganhou medalha de bronze na Centennial Exposition. O bordado rico que ostenta conta com folhas de carvalho e espigas de trigo em tons de dourado. Ainda que não fosse uma peça para ser exibida publicamente, o corset representava a prosperidade e riqueza da mulher - ou de seu marido através dos bordados com tais motivos.

Figura 19 - Corset da Royal Worcester Corset Company (1876) adornado com bordados.

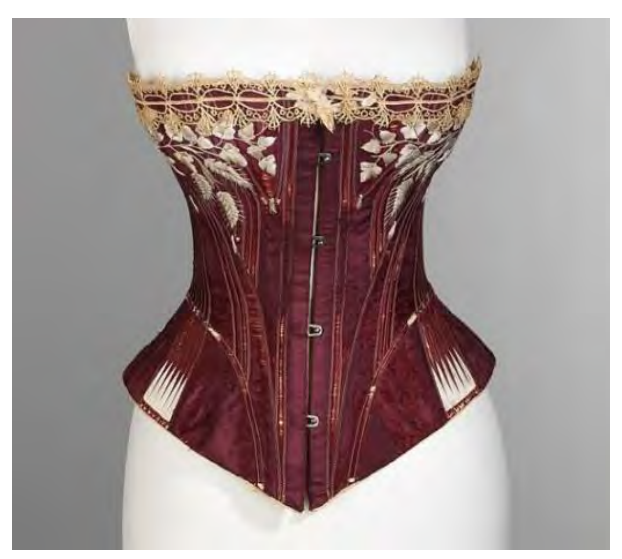

Fonte: Metropolitan Museum of Art ${ }^{27}$

Há ainda um potencial muito forte em bordar trajes interiores. Por ficarem em contato direto com o corpo, esses trajes podem ter grande força mística. Muitas culturas tradicionais têm rituais ligados à fertilidade que envolvem bordar tecidos com elementos e imagens específicas: um símbolo de fertilidade bordado num traje interior, por exemplo, pode ser um modo de tentar garantir filhos para um casal. No Brasil, há uma tradição bastante popular de bordar nos forros de vestidos de noiva, nomes das amigas solteiras (Figura 20). Acredita-se que isso seria um modo de atrair um casamento para essas mulheres também. Não foram encontradas fontes exatas de como essa tradição teria surgido, mas ela parece ser principalmente brasileira.

\footnotetext{
${ }^{27}$ Disponível em: <http://www.metmuseum.org/art/collection/search/158007>. Acesso em 13 Dez. 2017.
} 
Figura 20 - Nomes bordados aplicados na anágua de um vestido de noiva

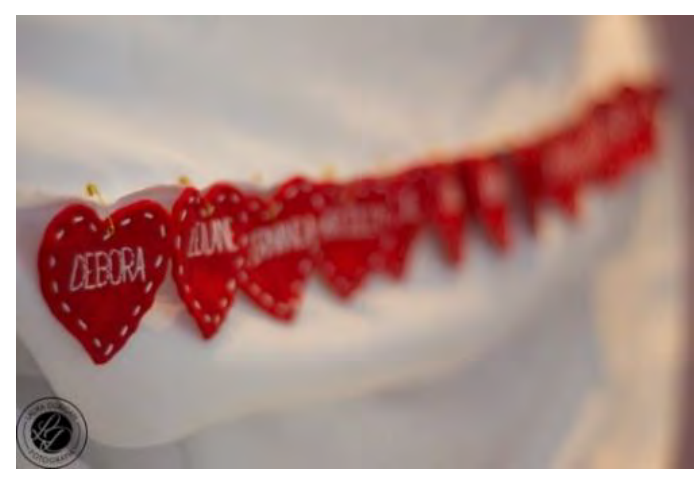

Fonte: $\mathrm{Elo}^{28}$

\subsubsection{Traje de folguedo}

Tomando-se como base a ideia de que o bordado é uma das técnicas mais antigas para se adornar ou modificar - inclusive de maneira mágica - um traje, então parece lógico que os trajes de folguedo sejam fortemente ligados à técnica, que carrega, neste caso, uma carga simbólica muito forte. Por vezes, nas escolhas das cores e materiais, noutras pelos formatos e desenhos executados, esses trajes trazem mensagens sobre quem os usa e por qual motivo através de mensagens secretas nos bordados.

A exposição Alta Moda (2013) com fotografias de Mario Testino, se dedicou a mostrar trajes peruanos da região de Cuzco. A exposição, exibida no Museo Mario Testino (Lima, Peru), exibiu trajes que pertencem - e são conservados - pela Filigranas Peruanas, instituição que visa à conservação da arte e folclore da região. Esses trajes já não são mais usados no dia a dia, mas sim em situações especiais - como festividades e funerais - e em folguedos de datas específicas no ano ${ }^{29}$.

Os bordados típicos da região são conhecidos como maquinasqa, que são faixas bordadas na máquina de costura. Apesar de serem realizadas com o auxílio da máquina, os desenhos e a execução são feitos pelas mãos das bordadeiras. Não há uma programação eletrônica que coordene os movimentos ou desenhos. Essas faixas são aplicadas nos trajes em locais estratégicos para adorná-los. Elas podem também ser costuradas umas nas outras, dando forma a peças inteiras como saias e casacos. Há peças também em que os bordados são feitos diretamente sobre o tecido, mas também utilizando o auxílio da máquina de costura.

\footnotetext{
${ }^{28}$ Disponível em: <https://www.elo7.com.br/coracoes-para-barra-do-vestido-de-noiva/dp/519A2C > Acesso em 11 Jan. 2018.

${ }^{29}$ Disponível em: < https://artsandculture.google.com/exhibit/fgJS-m1A4V1zLw> Acesso em 10 Out. 2018.
} 
Na Figura 21 vê-se um exemplo de traje de folguedo do povo Paucartambo em honra à Virgem Del Carmen e ao Señor de Qoyllurit'i. Essa dança, representa os muleiros nômades de Collao, região ao sul da Cordilheira dos Andes. Esses muleiros viajavam com caravanas de lhamas realizando escambos - principalmente de alimentos. Essa dança é formada por cerca de trinta homens e uma personagem feminina (também interpretada por um homem), que representa uma pastora. Eles usam chapéus bordados à mão, com linhas e pedras, com a imagem da Virgem Del Carmen e do Señor de Qoyllurit'i ou com representações de paisagens e da fauna local. Os demais bordados são feitos com a técnica da maquinasqa. Eles carregam fios de lã nas mãos enquanto dançam e fazem gestos mimetizando o ato de tecer.

Figura 21 - Traje da dança Qhapaqqolla, distrito e província de Paucartambo, Cuzco, Peru, 2010.

Fotografia de Mario Testino.

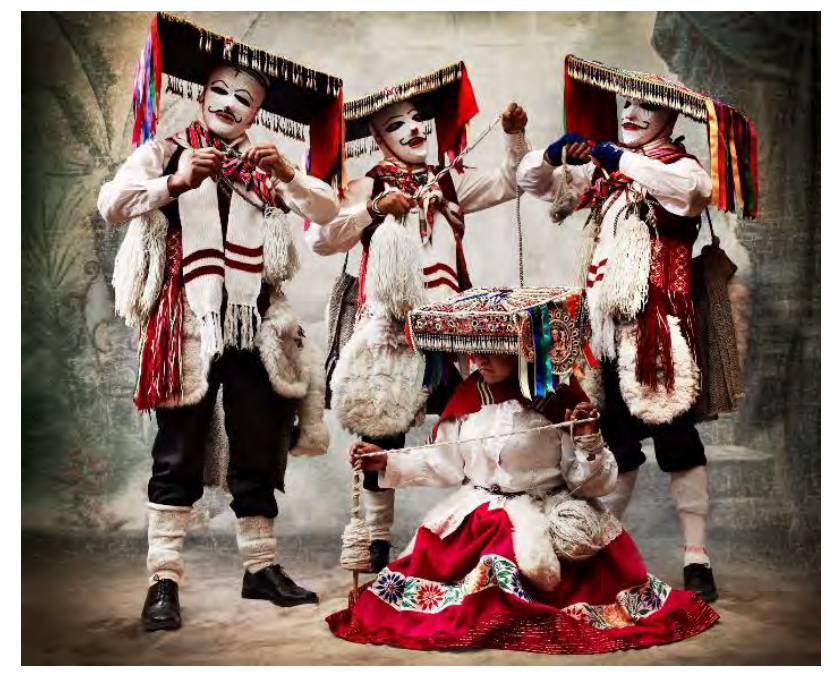

Fonte: Google $\mathrm{Arts}^{30}$.

\subsubsection{Traje esportivo}

O bordado no traje esportivo parece aparecer principalmente com a função de identificação. Nesse caso, o bordado pode ser tanto demonstrando qual a marca que produziu o traje, como indicando à qual time aquele traje pertence - no caso de trajes licenciados de times ou pertencentes a jogadores em competições. Esses bordados podem ser tanto realizados diretamente sobre o tecido quanto bordados separadamente e aplicados sobre a roupa. Alguns trajes esportivos de seleções também bordam estrelas sobre os escudos de acordo com o número de campeonatos ganhos por aquele time. Nesse caso, o bordado também é uma espécie de

\footnotetext{
${ }^{30}$ Disponível em: < https://artsandculture.google.com/asset/mario-testino-alta-moda/hQFm0trr9P4z8w $>$ Acesso em 25 Set. 2018.
} 
condecoração. Na Figura 22, vê-se um detalhe da Camisa Masculina do time Internacional, especial Outubro Rosa - 2017. O logo do patrocinador foi bordado diretamente sobre a camisa e o escudo do time foi aplicado.

Figura 22 - Camisa do Internacional (Outubro Rosa - 2017).

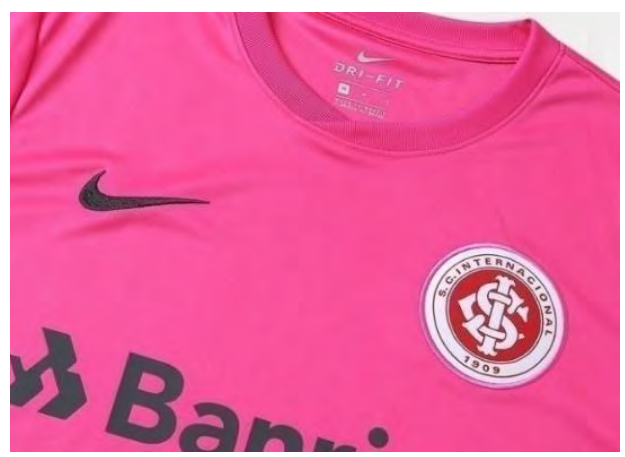

Fonte: Site do Internacional Sport Clube ${ }^{31}$

Por vezes, também pode ser encontrado com função estética em esportes cujos trajes fazem parte da apresentação dos atletas, como nado sincronizado, patinação, ginástica olímpica, etc. Porém, possivelmente devido ao grande número de adornos em trajes que exigem muita mobilidade, é menos comum de se encontrar. Normalmente apenas alguns detalhes são bordados com pedrarias e os outros são colados no traje. Um exemplo é o traje que a patinadora artística Gabriela Papadakis usou na semifinal da patinação artística, modalidade Dança no Gelo, do Campeonato Europeu de Figure Skating (2018).

Figura 23 - Gabriella Papadakis e Guillaume Cizeron

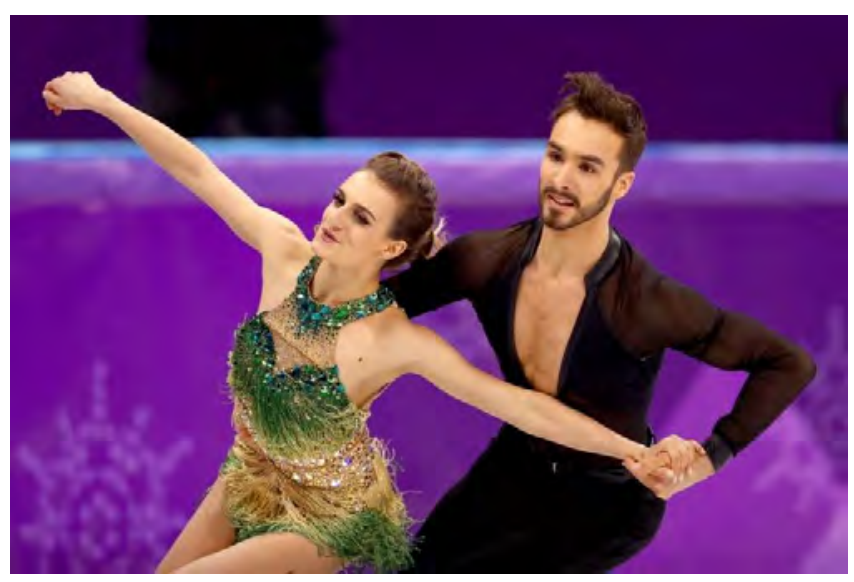

Fonte: Boa Forma ${ }^{32}$

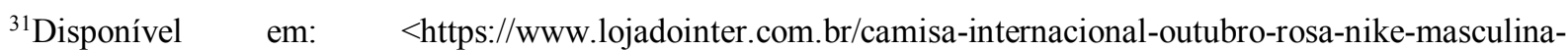
rosa+chumbo-D12-8754-675>. Acesso em 13 Dez. 2017.

${ }^{32}$ Disponível em < https://boaforma.abril.com.br/estilo-de-vida/apresentacao-de-patinadores-ao-som-de-shapeof-you-e-emocionante/> Acesso em 25 Set. 2018.
} 


\subsubsection{Traje fúnebre}

O traje fúnebre é aquele usado na hora do sepultamento, ou seja, a última roupa que alguém irá colocar. Esse traje pode revelar muito sobre aquele que o usa: sua classe social, gênero, tamanho, hábitos em vida, etc. Esta é uma roupa carregada de muitos significados. Pode ser um traje social escolhido pela própria pessoa ou seus parentes ou um traje feito especificamente para essa ocasião. Além de uma função decorativa, os bordados desse traje também têm uma função de identificação, ou seja, assim como os outros elementos do traje, revelam sobre a origem, local, época e outras informações.

Na Figura 24 há um exemplo de traje funerário cuja análise ganhou repercussão: o de Eleonora de Toledo (1522-1562), encontrado na abertura do sepulcro da família Médici. Segundo o site do Archivio Médici Costume Textiles, o traje com que Eleonora foi enterrada foi restaurado e estudado, além de reconstruído para fins de estudo e documentais. Mesmo sendo do século XVI, o bordado do vestido se encontrava bastante preservado, possivelmente por ter sido confeccionado em fio de metal dourado forrado. Esse bordado revelava muitas informações: a condição social da família na época, as técnicas empregadas pelos artesãos naquele momento, os desenhos, entre outros.

Figura 24 - Detalhe do corpete de Eleonora de Toledo. (Foto: Janet Arnold)

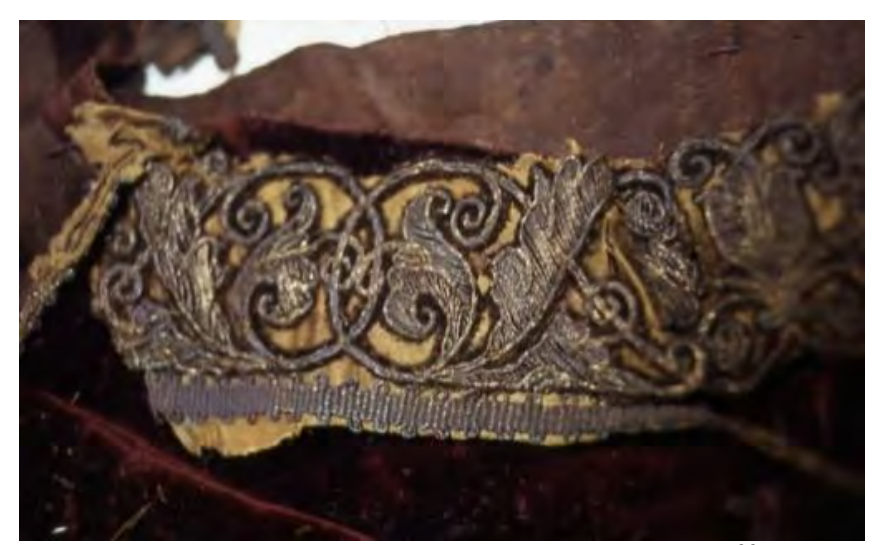

Fonte: Archivio Medici Costume Textiles ${ }^{33}$

Há ainda as mortalhas, panos feitos especialmente para envolver o cadáver no ato do sepultamento. Apesar de não ser mais um costume tão comum quanto em outros momentos históricos, as mortalhas foram usadas por muito tempo em diversas civilizações. Os bordados dessas peças podem ser decorativos ou mesmo narrativos por vezes, revelando sobre a vida do defunto ou de alguma entidade que o proteja.

\footnotetext{
33 Disponível em: <http://archiviomedici.costume-textiles.com/cerca.asp>. Acesso em 11 Jan. 2018.
} 
Figura 25 - Mortalha bordada com inscrição personalizada na borda. Produzida nos dias de hoje pelo Korban Workshop, em Vermont.

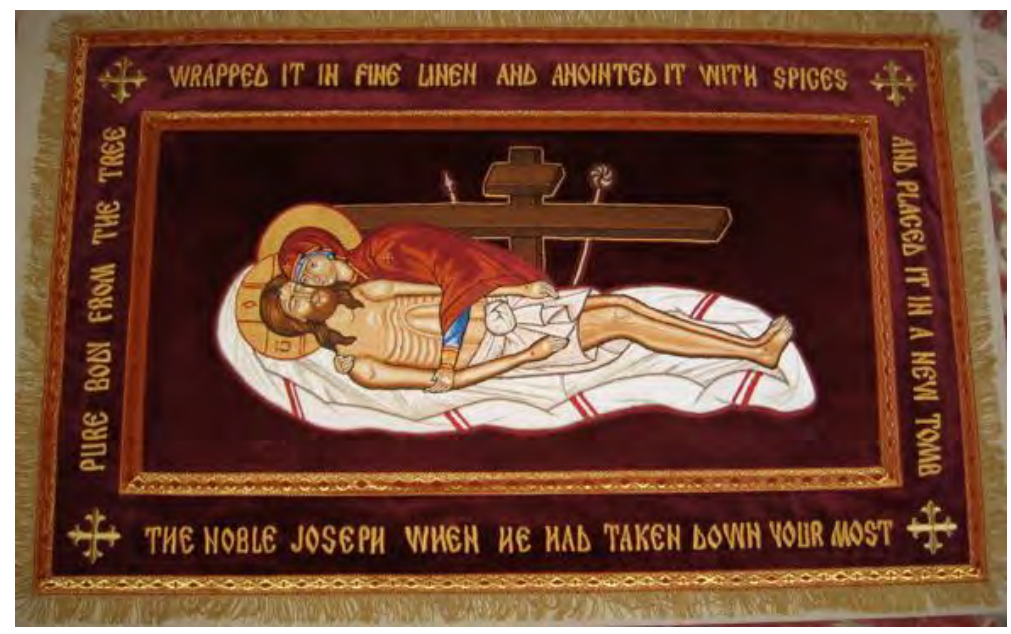

Fonte: Site Korban Workshop ${ }^{34}$

Sobretudo, há uma função ritual evidente nesses trajes. Eles deixam de ser uma roupa qualquer para se tornar uma roupa carregada de significados. Quando há bordados feitos especificamente para esse momento, eles assumem essa função com grande força, adquirindo potencial mágico e/ou religioso. Muitas culturas acreditam que nos trajes fúnebres podem estar as proteções necessárias para alcançar o mundo após a morte.

\subsubsection{Traje associacionista}

Os bordados nos trajes associacionistas costumam ajudar a indicar, junto com as cores, formas e demais elementos da construção do traja, a que sociedade especial o usuário daquele traje pertence. Além disso, podem servir para distinguir diferentes tipos da mesma sociedade. Eles têm, portanto, também uma função de identificação.

Diferentes lojas maçônicas, por exemplo, podem possuir detalhes diferentes em seus trajes. Na Figura 26, vê-se um exemplo de Avental para Primeiro Vigilante - REAA GOB utilizado em lojas praticantes do Rito Escocês Antigo e Aceito, subordinadas ao Grande Oriente do Brasil (GOB). O traje é confeccionado em courino e tecidos (cetim, oxford), contendo bordados na parte frontal, detalhes em metais e um bolso na parte de trás do mesmo. Os bordados, apresentam diversos elementos simbólicos dentro da maçonaria.

\footnotetext{
${ }^{34}$ Disponível em: <http://korbanworkshop.com/Embroidered-Shrouds.html>. Acesso em 13 Dez. 2017.
} 
Figura 26 - Avental para Primeiro Vigilante bordado.

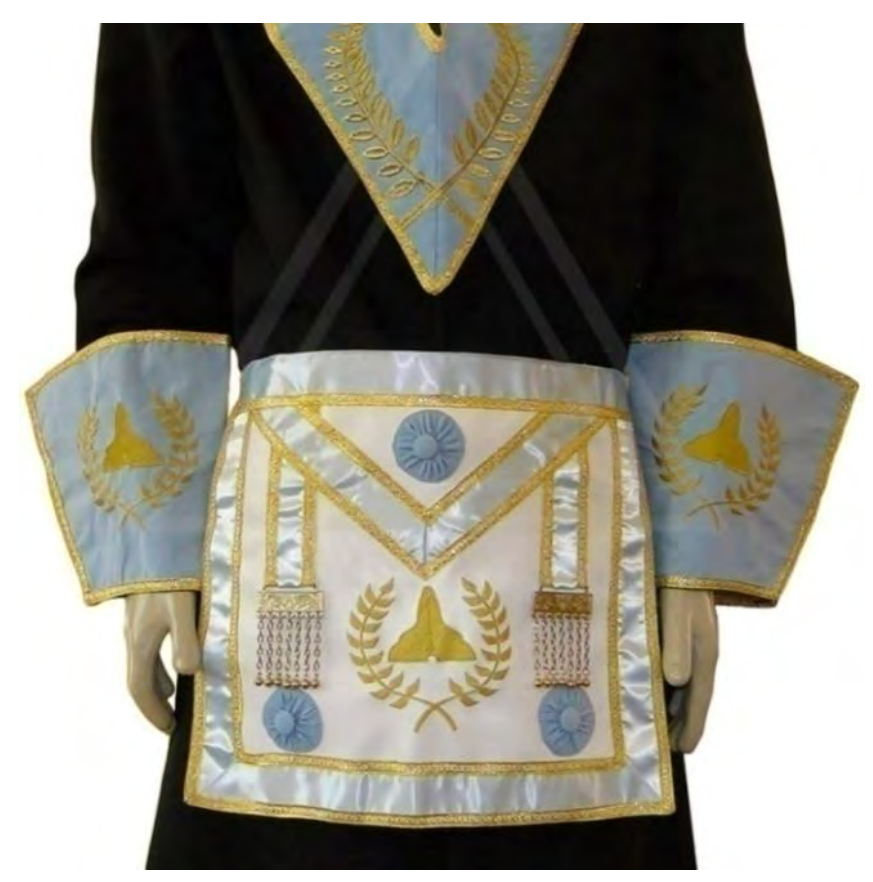

Fonte: Site Horus Alfaia ${ }^{35}$

\subsubsection{Traje etnográfico}

O traje etnográfico é aquele que pertence a um povo, uma comunidade ou grupo social específico. Muitas vezes, estes são trajes que já há muito não são mais usados pelos povos. Em um traje etnográfico o bordado tem função majoritariamente de identificação. Este traje está ligado à história e as transformações que um povo passou. Nele se encontram informações sobre os povos que os utilizavam, quais eram suas crenças e seus hábitos.

Na Figura 27, vê-se um exemplo de traje etnográfico moldavo do fim do século XIX. A cena retratada na fotografia faz parte da exposição permanente do Museu Etnográfico Russo, de São Petersburgo. A população da Moldávia era de composição complexa: assentados na antiga província bessarabiana da Rússia, os moldávios viviam próximos a russos, ucranianos, búlgaros, gagauzes, poloneses, ciganos e judeus. A figura mostra um dos cenários da exposição: a Casa Mare. Segundo Irina Baranova para o site ${ }^{36}$ do museu:

O lugar central na exposição é ocupado pelo modelo da grande sala da casa da Moldávia. A casa típica do camponês moldavo, dependendo da riqueza, consistia em dois (uma sala e um alpendre) ou três quartos. O terceiro era um quarto de hóspedes chamado kasa-mare, que sempre permanecia elegantemente vestido, como se estivesse em constante expectativa dos convidados(...). Eventos familiares importantes e rituais eram celebrados na Kasa-Mare. A exposição mostra a cena

\footnotetext{
${ }^{35}$ Disponível em: <https://horusalfaia.com.br/avental-primeiro-vigilante-gob-maconaria>. Acesso em 13 Dez. 2017.

${ }^{36}$ Disponível em: < http://ethnomuseum.ru/moldavane-konec-xix-nachalo-Xx-v> Acesso em 25 Set. 2018.
} 
situacional onde no quarto de hóspedes é feita uma das cerimônias de casamento da Moldávia - vestir cerimonial da noiva por sua mãe antes de ir para a mesa de casamento. Segundo uma antiga tradição, neste momento a noiva estava chorando, e seus amigos cantam canções tristes, que lamentavam o destino da noiva, deixando a casa dos pais de família do marido. (BARANOVA, sem ano)

Figura 27 - Trajes etnográficos da Moldávia do século XIX (A noiva e sua mãe), no Museu Etnográfico Russo.

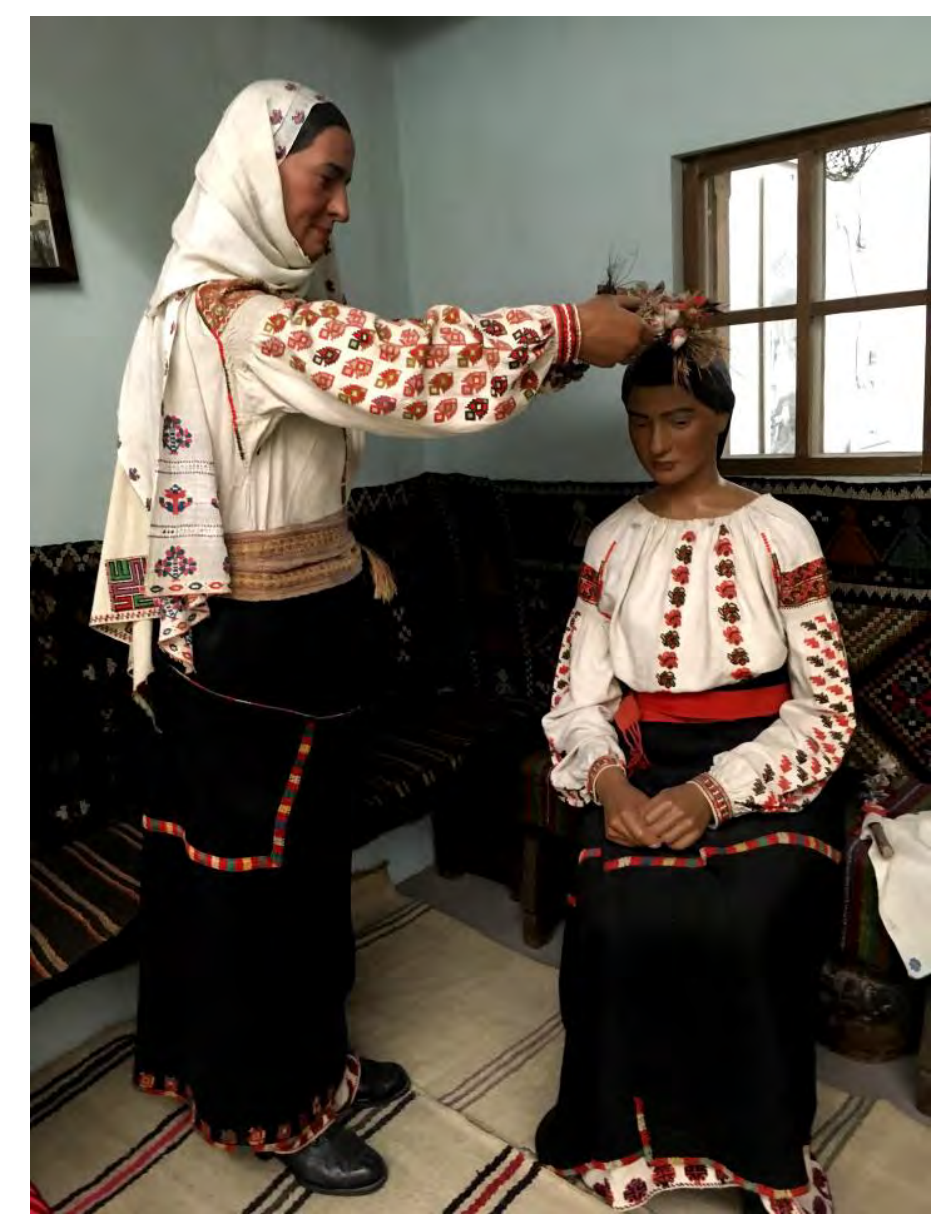

Fonte: Acervo da autora.

\subsection{Os principais usos no traje de cena}

Para Cunningham (1989), o traje de cena é um traje mágico. Se desde a pré-história os homens usavam trajes rituais para transportar seus espíritos e assumir outras personas, os trajes de cena teriam herdado esse aspecto mágico atribuído a vestes em representações. De fato, o aspecto ritual do traje de cena foi explorado por outros teóricos por sua capacidade de mudar o ator que o veste em uma personagem. Pavis (2008) afirma também que o figurino sempre esteve presente enquanto traje ritual ou cerimonial em diferentes momentos históricos em que a encenação teatral e mítica/religiosa se entrelaçavam. 
Quando se pensa nos potenciais narrativos do bordado e nas narrativas visuais no teatro, vê-se que essa ideia de que o figurino teatral deve ser mais que apenas uma roupa que o ator usa não é nova. Diversos encenadores modernos propuseram trajes de cena que transcendiam o mero adorno e contavam eles próprios uma história. Dentre eles, destaca-se Antonin Artaud (1896 - 1948), que apesar de ter realizado menos projetos como encenador se comparado a outros artistas, teve grande preocupação com a criação do figurino teatral. Segundo Viana (2010), Artaud se dedica a elaboração de conceitos sofisticados sobre o traje de cena e que para ele "o figurino do teatro não é meramente uma roupa, e sim um instrumento ritual, indispensável para a realização cênica do ator” (p. 178). Também sobre a percepção de Antonin Artaud sobre o assunto, Pereira (2012) diz:

\begin{abstract}
Segundo o próprio Artaud (1999), o figurino de teatro não é meramente uma roupa e sim um indispensável instrumento ritual para o ator, que através da solenidade do hieratismo poderia lhe imprimir o duplo; o artista embrulhado em sua roupa passaria a ser uma efígie de si mesmo. Ou seja, Artaud se refere aqui aos trajes milenares e de uso ritual, sem afirmar que haja uma roupa uniforme para todos os espetáculos teatrais e sim um traje que mesmo de época em certo momento da história ainda conserve em si uma aparência reveladora em virtude da proximidade que este mantém com as tradições que lhe deram origem e que sirvam de conexão para o ator e para o público do mundo visível ao mundo invisível, seja do ponto de vista religioso seja do ponto de vista psicanalítico. (PEREIRA, 2012, p. 4)
\end{abstract}

Portanto, quando se fala em traje de cena, não é possível deixar de considerar os aspectos rituais que o bordado pode assumir quando presente. Um ator, por exemplo, que borde uma palavra de oração ou uma medalha em seu figurino para lhe conferir proteção ao entrar em cena, estaria conferindo um aspecto mágico ao bordado no traje. Porém dentro do universo das artes cênicas, este aspecto ritual se encontra em maneiras não necessariamente idênticas às apresentadas no item 1.1.3. Se o traje de cena auxilia na transformação do corpo do ator em corpo da personagem, o bordado pode ser um elemento que participa deste ritual. Muitas vezes o bordado não é necessariamente visto pelo público, ou seja, ele é criado para que seja visto apenas pelo ator e, assim, possa o auxiliar na sua transformação. São detalhes que transformam a relação entre o ator e a personagem a partir do traje.

Evidentemente, o aspecto decorativo do bordado é muito importante na criação de trajes de cena. Principalmente quando se pensa em trajes para ópera e balé, que costumam ser apresentados em palcos de maiores proporções, os adornos bordados ajudam a adicionar textura, cor e volume aos trajes. Assim eles são visualmente interessantes mesmo à distância. Também tornam os trajes mais ricos dependendo da maneira com que são trabalhados. Teatros 
antigos e tradicionais costumam contar com oficinas próprias onde se criam os trajes de cena e, nestas oficinas, trabalham profissionais especializados em diversas manipulações têxteis.

Figura 28 - Condessa Almaviva, de As Bodas de Fígaro, Opera de Paris (1973)

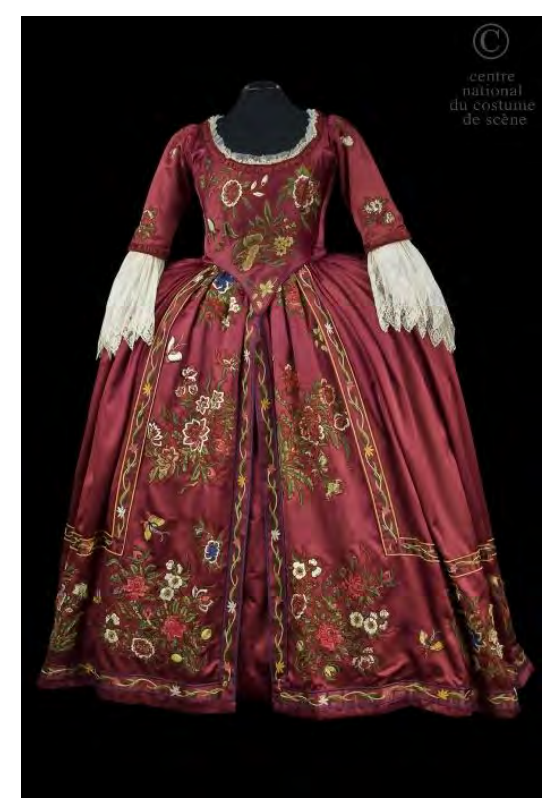

Fonte: Site $\mathrm{CNSC}^{37}$

O bordado pode também ressignificar um traje. Muitos figurinistas e encenadores têm a prática de criar trajes de cena a partir de trajes sociais pré-existentes. Através de processos de customização e adição de novos elementos, os trajes são ressignificados de modo a trazerem novas informações à cena. De modo inverso, um bordado também pode ser ressignificado em cena. Uma toalha de mesa bordada, por exemplo, pode ser usada para criar véu de noiva em um traje de cena e, com isso, adquirir uma série de novas interpretações. Há ainda uma possibilidade que o bordado seja utilizado para criar ilusão visual ao espectador. Por ser uma técnica que dialoga com diferentes volumes e texturas, pode dar forma ao corpo do ator, interagir com a iluminação de modo a modificar a visão do traje, entre outros. É também uma maneira de ressignificar o traje e lhe conferir outras interpretações. Na Figura 29, vê-se exemplos do figurino da novela Orgulho e Paixão (2018), criados a partir de vestidos de noiva de outras produções. Os trajes foram tingidos e rebordados para se tornarem trajes de baile do séc XVIII.

Há ainda outros usos e caso que se poderiam considerar. Há performers, por exemplo, cujo trabalho envolve bordar seu traje de cena como parte da ação performática. Assim, não só

\footnotetext{
${ }^{37}$ Disponível em: < http://cncs.skin-web.org/costume/la-comtesse-3> Acesso em 25 Set. 2018.
} 
o bordado é parte do traje de cena - construído pelo próprio ator - como o gestual envolvido na realização da técnica é parte do espetáculo. A performance Barocco (2009), de Kirstie MacLeod (Figura 30) terá realização total de dez anos. Ela é realizada dentro de uma caixa de vidro, em que a performer borda o vestido que está usando em frente à plateia. Este vestido viaja por diversos países e, em cada um deles, um grupo de pessoas colabora bordando parte dele também ${ }^{38}$.

Figura 30 - Performance Barocco (2009)

Figura 29 - Figurino da novela Orgulho e Paixão (2018).

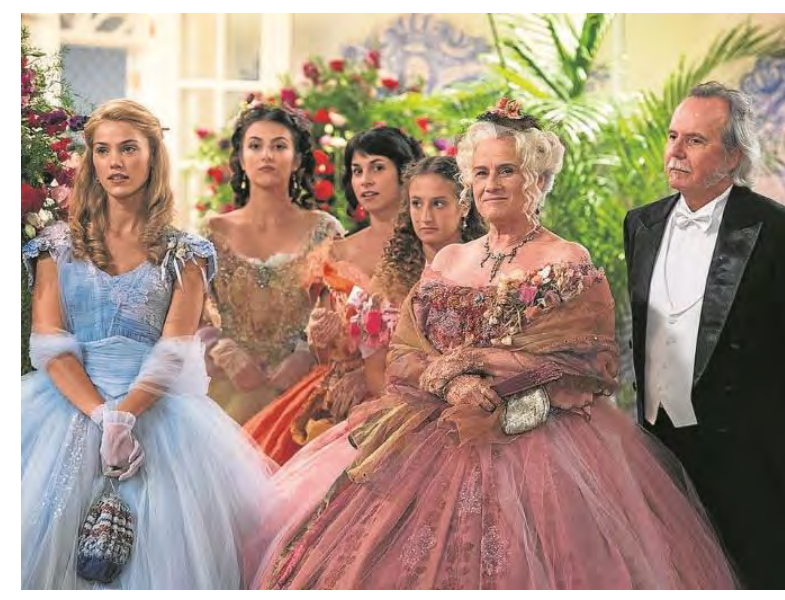

Fonte: Estadão ${ }^{39}$

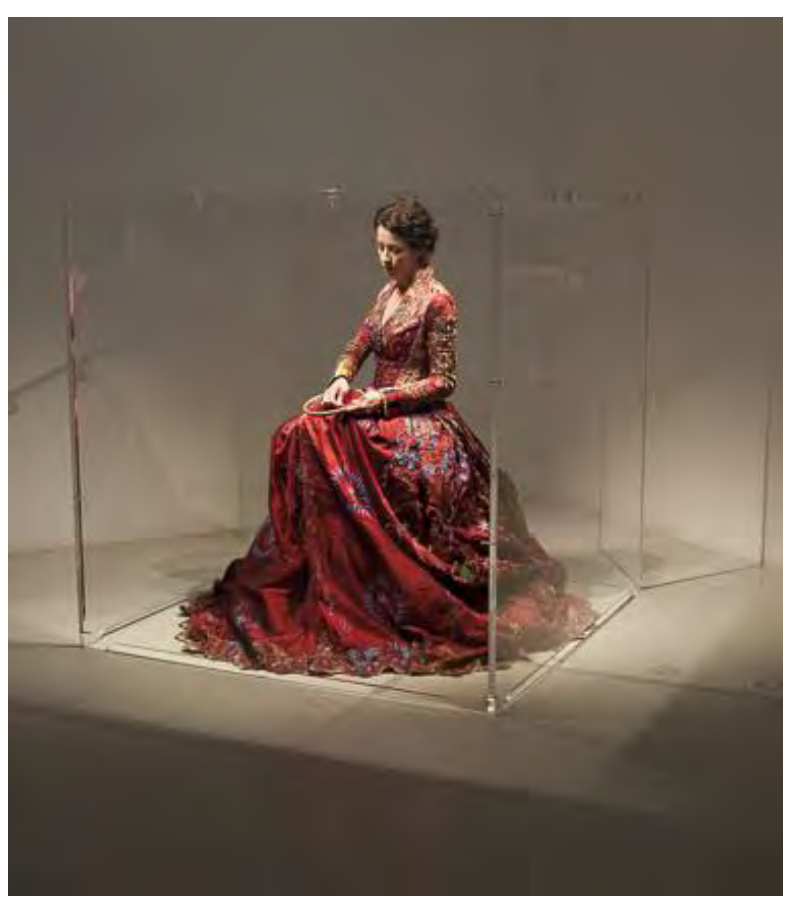

Fonte: Site Bedeles

Quando se fala em um potencial uso narrativo do bordado no traje de cena, há que se pensar nos diversos tipos de narração que pode emergir dessa relação. O bordado pode aparecer de maneira narrativa em muitos aspectos: eles podem tanto reforçar informações e dados conhecidos da história contada e das personagens, quanto trazer novas informações e criar novas narrativas, fazendo um uso simbólico. Pode-se também criar trajes que contem com narrativas lineares utilizando um bordado pictórico.

\footnotetext{
${ }^{38}$ Disponível em:

$<$ www.bedales.org.uk/sites/default/files/Kirstie\%20Macleod\%20Punctured\%20Perspectives.pdf $>$ Acesso em 21 Set. 2018.

${ }^{39}$ Disponível em < https://cultura.estadao.com.br/noticias/televisao,orgulho-e-paixao-traz-figurino-de-epoca-naera-da-alta-definicao,70002272914> Acesso em 25 Set. 2018.
} 
A narração pode, no entanto, estar também presente de maneira abstrata, nas relações entre os envolvidos na criação do traje de cena e o traje em si. O encenador Gabriel Villela (ver subitem 2.3.), por exemplo, tem um trabalho com forte presença do bordado e da manipulação criativa dos têxteis. Esta escolha se relaciona com a própria história de vida do artista e com a construção de um universo visual particular, muitas vezes se referenciando em suas próprias obras anteriores. As narrativas criadas ali se expressam no bordado e propõe gamas de significados além das internas ao espetáculo, já que se relacionam com signos extra palco.

Nesta pesquisa, a atenção maior estará em analisar os usos narrativos especialmente relacionados os processos criativos dos figurinistas e os materiais escolhidos por eles com a presença do bordado como parte relevante na construção dos trajes. Ainda que este seja o foco principal, se apresentarão, a fim de encerramento da primeira parte desta pesquisa, dois breves ensaios que analisam trajes de cena em que o bordado foi primordial.

\subsubsection{Uso decorativo em Jewels (1967)}

Um traje de dança é pensado segundo as necessidades da coreografia e dos movimentos do dançarino: dependendo do papel interpretado, por exemplo, se exige mais ou menos movimentos, o que também influencia na confecção do traje de cena. Uma bailarina principal, cujo papel exige virtuosismo técnico e muitas movimentações de pernas e braços precisa de trajes de tecidos mais leves e fluidos que um personagem secundário masculino, como os vilões, que têm menos movimentos amplos. Tudo isso deve ser levado em conta na produção do traje. É um campo muito especializado, com diferentes profissionais envolvidos na tarefa de refletir o conceito do trabalho ao mesmo tempo em que se atentam às demandas da dança e aos efeitos que cada tipo de material vai gerar no palco. Além disso, como qualquer traje de cena, deve dialogar com os outros elementos da cena, como o cenário e a iluminação, de modo a gerar um todo coerente.

O traje de balé, especificamente, pode ser tanto uma adaptação de um traje do dia a dia como seguir às regras de uma cultura em especial. Ele também tem a responsabilidade de respeitar tradições internas: um traje do Lago dos Cisnes, por exemplo, já está gravado na mente do público, que espera ter suas expectativas atendidas ao assistir a essa montagem. Provocar uma ruptura nessas tradições internas deve ser uma escolha muito consciente que deve se refletir em todos os aspectos, inclusive nos trajes de cena. O traje de balé deve também considerar possíveis interações entre dançarinos e cenário: um tecido escorregadio não poderia ser 
utilizado num traje para uma bailarina que fosse ser levantada no ar pelo seu parceiro; também não poderia ter ornamentos que corressem o risco de enroscar no traje do seu par, entre outras preocupações.

A técnica do bordado é uma ótima opção para adornar os trajes por diversos motivos. Uma vez que, de forma geral, a base do traje de balé são as malhas, é preciso que se adicionem elementos que possam dar volume e textura. Como o bordado é uma técnica que permite muita liberdade de desenhos e detalhes, é fácil utilizá-lo para criar adornos que tornem as malhas mais significativas no palco. Além disso, são trajes feitos para serem vistos de longe, já que as casas em que os balés se apresentam costumam ser muito granes. Por isso, os trajes precisam de um trabalho estético que valorize e desenhe a silhueta do dançarino, para que ele não suma à distância no palco.

Os trajes de balé costumam ser bordados com pedrarias, contas, miçangas, cristais, etc. Esses materiais devem ser escolhidos pensando não só na estética como no conforto e mobilidade dos bailarinos. Pedrarias muito pesadas atrapalharão o desempenho do dançarino no palco; então os bordados nesses trajes devem ser ao mesmo tempo marcantes, com muita presença, e leves.

O bordado nos trajes de balé também tem utilidade prática. Normalmente realizado com pedrarias, miçangas, fios metálicos, entre outros, ele interage com a iluminação do espetáculo, produzindo texturas e volumes nos trajes. Além disse, ao refletir luz também pode ajudar a construir melhor visualmente uma personagem. Uma bailarina interpretando uma personagem mítica, cujos trajes contem com bordados que reflitam a luz de uma determinada maneira, pode adquirir um aspecto etéreo e místico, fortalecendo o discurso sobre ela. Uma vez que o balé não possui falas, é preciso buscar sempre soluções visuais que comuniquem ao público aquilo que se quer dizer. BARBIERI (2017), em sua análise de um traje de balé do século XVIII, diz que:

O bordado ousado, em alto relevo, metálico sugere o formato de uma couraça, colocado sobre um veludo escarlate de estofado, se estendendo ao peplum e à saia para enfatizar o movimento e estrutura. Assim como as mudanças da direção dos pontos do bordado deviam capturar e refratar a luz das velas do teatro, as franjas trançadas nas bordas deveriam brilhar e tornar o movimento ainda mais magnífico. (BARBIERI, 2017, p. 43, tradução nossa)

Na Figura 31 vê-se um exemplo de uso do bordado para promover interação entre o traje e outros elementos da narrativa visual do espetáculo. O traje pertence à montagem do balé Sonhos de Uma Noite de Verão (2017) da Ópera de Paris. Os figurinos foram idealizados por Christian Lacroix, que contou com o patrocínio da Swarovsky. Os mais de duzentos trajes 
utilizados ao longo do espetáculo foram bordados com mais de um milhão de cristais, fios metálicos e renda Chantilly para que, quando a luz incidisse, fosse criado um brilho etéreo em torno das bailarinas.

Figura 31 - Traje para Sonhos de uma noite de verão

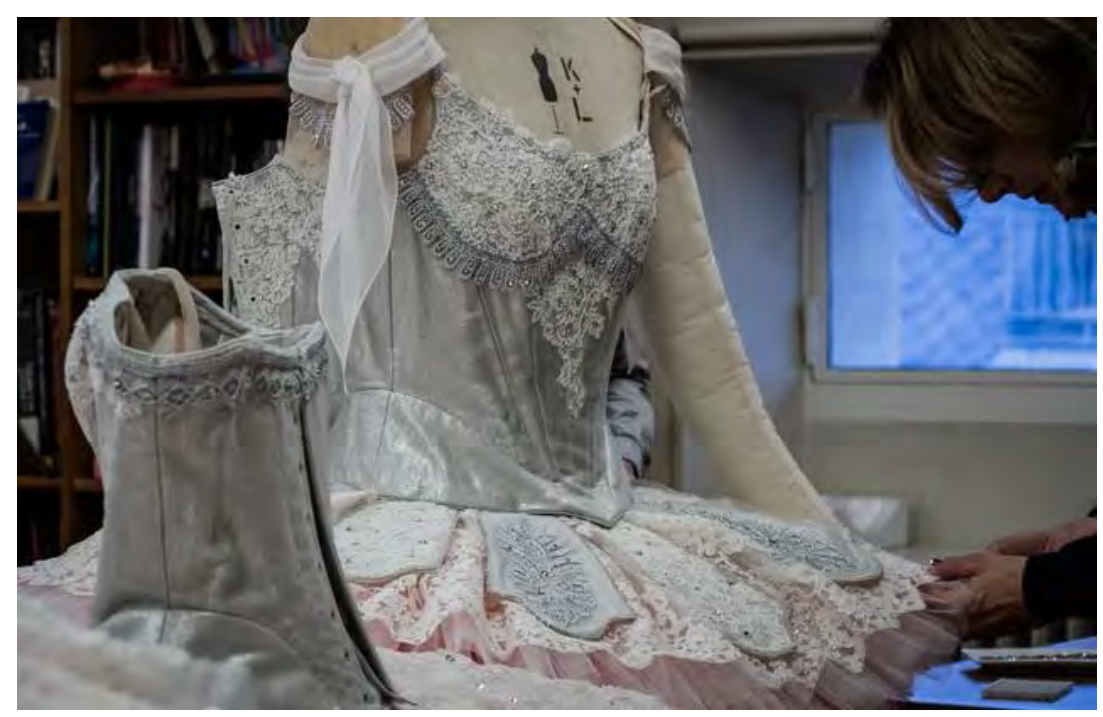

Fonte: Site Vogue $e^{40}$

Claro que, ao longo do tempo, muitas opções estéticas dos trajes de balé foram dadas de acordo com as possibilidades financeiras. O balé é uma dança muitas vezes ligada ao luxo e isso fica claro na construção dos trajes. Cabe ao figurinista responsável pela produção encontrar soluções que sejam mais acessíveis sem prejudicar a estética como um todo e nem deixar de produzir os efeitos que um bordado no traje proporciona.

Uma das artistas mais conhecidas pelos usos do bordado nos trajes de balé é Barbara Karinska. Nascida na Rússia em 1886, filha de uma família de posses, ela aprendeu ainda criança as habilidades de uma dama da sociedade. Nas artes manuais, seu principal foco foi o bordado, técnica de grande tradição na Rússia. Foi graças a essa habilidade, consegue sobreviver em momentos de crise - principalmente no período da Revolução Russa, quando muitas das famílias mais ricas se viram de repente privadas de seus bens. Além de produtos bordados que produzia para vender, Karinska também abriu uma escola de bordado onde fazia o que chamava de pinturas com tecidos - aplicações de tecidos em outros, formando assim formas e cores, que seriam determinantes no papel que ela viria exercer no futuro, como realizadora de figurinos (VIANA, 2016).

40 Disponível em < http://vogue.globo.com/Suzy-Menkes/en/noticia/2017/03/christian-lacroix-fashion-wasaccident.html $>$ Acesso em 25 Set.2018. 
A Rússia vivera no século XIX uma revitalização do interesse no bordado, principalmente o trabalho dos bordados em trajes regionais camponeses. Movimentos que rejeitavam a arte pela arte tomavam conta do país e havia um desejo de dar utilidade prática às técnicas artísticas. (PARKER, 2010). Nesse ínterim - e também numa tentativa de se voltar mais para dentro do país do que para as referências externas - o bordado tradicional russo começou a aparecer nas obras de arte produzida pelos artistas contemporâneos. A artista têxtil Sonia Delaunay, por exemplo, usava de sua tradição russa e a retrabalhava de forma a tornar o bordado uma forma de expressão artística, misturando arte e moda. Ainda segundo Parker (2010), essa apropriação artística do bordado foi possível porque ele é "essencialmente uma técnica universal ou intuitivo" (p. 193).

Com essa popularização do bordado nas artes, sua procura aumentou, possibilitando também o surgimento de oficinas e lojas especializadas. Foi nesse contexto que Karinska encontrou o espaço para trabalhar com a arte até então usada apenas de maneira decorativa e caseira pelas mulheres das famílias mais abastadas.

O trabalho de Karinska com o balé começa em 1933 quando ela trabalha em parceria com Christian Berard executando os trajes elaborados por ele para o espetáculo Cotillion. Segundo Stevenson, ainda que os trajes tivessem sido criados por Berard, era Karinska quem escolhia os tecidos e fazia as modificações necessárias para que os trajes fossem adequados aos dançarinos e ao palco (STEVENSON, 2011, p.3).

O conforto dos performers era uma preocupação frontal para Karinska. Para ela, além de visualmente bonito, o traje precisava responder às demandas dos dançarinos, tanto no conforto quanto na preservação, garantindo que aquele traje mantivesse sua integridade ao longo da temporada. Foi esta atenção aos detalhes e conhecimento de modelagens e tecidos que a levou a redesenhar o tutu, fazendo com que ele se aproximasse do seu ideal de traje funcional. O tradicional tutu prato, usado então no balé russo, não agradava a Balanchine nem a Karinska por sentirem que ele limitava os movimentos do dançarino. O tutu romântico, que chegava até os tornozelos dos dançarinos, por outro lado, mostrava menos o corpo dos bailarinos do que eles gostariam. Diante disso, Karinska criou o poder puff tutu, conhecido em português como Tutu Balanchine: uma saia com menos camadas de tule e sem a estrutura metálica interna. Mais leve e mais curto, esse tutu permitia uma movimentação mais fluida aos dançarinos.

O corpete também foi reelaborado por Karinska buscando maior funcionalidade. Anteriormente construídos de maneira semelhante aos espartilhos, com estruturas internas rígidas que restringiam os movimentos dos bailarinos. A solução encontrada por ela para tornar 
o corpete mais confortável e móvel foi construí-lo com uma modelagem diferente, cortando o tecido em direções que permitissem que ele ganhasse mais estrutura. Ela também utilizou mais tecidos de fibra natural para que a transpiração dos bailarinos não desgastasse tanto o tecido, ao mesmo tempo que garantia boa interação com a luz. Posteriormente, se discutirá como esta união entre funcionalidade e estética também aparece nos usos do bordado em seus trajes.

Os principais trabalhos em figurino de Karinska foram em parceria com George Balanchine. Depois de Cotillion, ainda no Balé Russo de Monte Carlo, eles trabalharam juntos em seis espetáculos na Europa e, posteriormente, em muitos outros nos Estados Unidos, onde Balanchine produziu algumas de suas obras mais memoráveis. Karinska criou e produziu mais de 9000 trajes de cena ao longo dos vinte anos em que trabalharam juntos. Um dos espetáculos mais interessantes dessa parceria é o balé Jewels, criado para o New York City Ballet, em 1967.

Jewels é considerado um dos primeiros balés abstratos: ele não possui nenhuma estrutura dramática. A inspiração para a criação do balé veio do designer artesanal de joias Claude Arpels. O espetáculo é dividido em três atos e cada um representa uma pedra preciosa: Esmeralda, com músicas de Gabriel Urbain Fauré, Rubi com músicas de Igor Stravinsky, e Diamante, com músicas de Peter Tchaikovsky.

Figura 32 - Patricia McBride, Violette Verdy, Mimi Paul e Suzanne Farrell em "Jewels", de George Balanchine (1967).

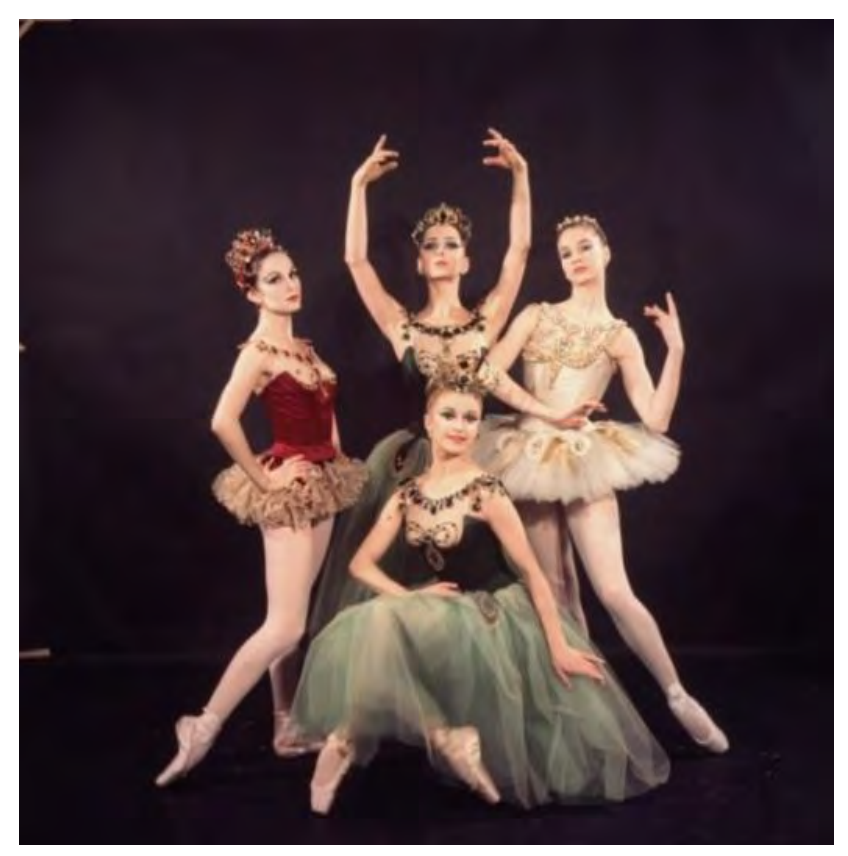

Fonte: New York Public Library ${ }^{41}$

\footnotetext{
${ }^{41}$ Disponível em: < Fonte: https://digitalcollections.nypl.org/items/41bafb70-258b-0132-b4bf-58d385a7b928>
} Acesso em 25 Set. 2018. 
Como cada momento fora composto por um músico, o espírito e significado de cada um dos atos é diferente entre si e isso se encontra também na composição dos figurinos. Segundo descrição do site do George Balanchine Trust ${ }^{42}$, o primeiro ato, Esmeraldas, era uma evocação da França, sua elegância, modos de vestir e perfumes, se referenciando principalmente nas danças românticas do século XIX; o segundo ato, Rubis, é fresco e espirituoso, como era relação entre Stravinsky e Balanchine; e o terceiro e último ato, Diamantes, era uma rememoração dos tempos de grandeza do Império Russo e do Teatro Maryinsky, onde Balanchine estudara.

O primeiro desafio de Karinska na realização desse figurino era como reproduzir a estética das pedras preciosas. Isso porque, obviamente, pedras são muito pesadas e seria impossível utilizá-las para a construção do figurino, já que ia ser desconfortável aos bailarinos. Era preciso criar soluções para manter a cor e aspecto das pedras.

O traje das Esmeraldas tinha sua inspiração nos balés românticos, estilo surgido no século XIX. A principal característica dos trajes de balé esse período é o tutu em formato de sino que chegava até o meio da panturrilha. Além disso, o corpete era ajustado, revelando colo, pescoço e ombros. Era um epítome da delicadeza e ideais românticos. Karinska criou um traje semelhante para o primeiro ato. O tutu romântico era complementado pelo corpete que revelava o colo da bailarina. Assim como os trajes do período romântico, o traje Esmeralda conta com uma pequena manga adornada que deixa parte dos ombros desnudos. A cor predominante era, evidentemente, o verde.

Figura 33- Detalhe do traje Esmeralda, usado por Violette Verdy. (1967)

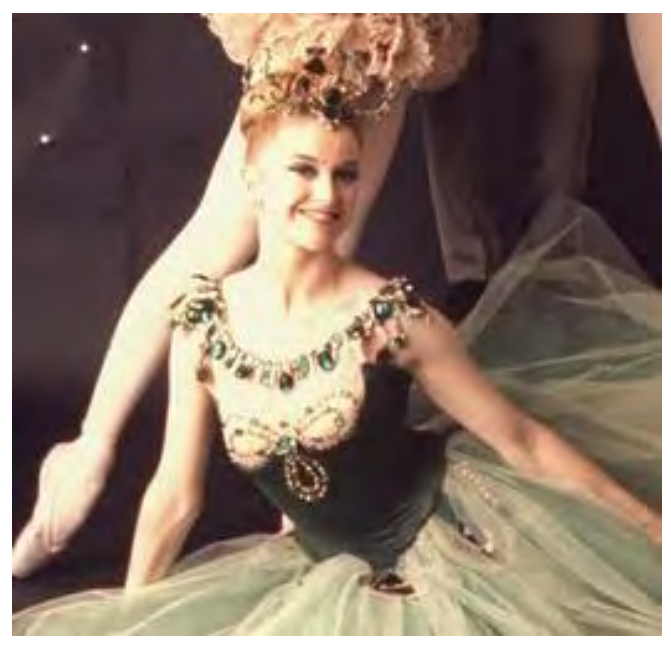

Fonte: New York Public Library ${ }^{43}$

\footnotetext{
${ }^{42}$ Disponível em: $<$ http://balanchine.com/jewels/> Acesso em 25 Set. 2018.

${ }^{43}$ Disponível em: < https://digitalcollections.nypl.org/items/55b14110-258b-0132-b64e-58d385a7b928> Acesso em 25 Set. 2018.
} 
Segundo Mal Barton ${ }^{44}$, a responsável pela oficina de figurinos do Royal Opera House e pelas reconstituições dos trajes para a última montagem de Jewels realizada lá, para tentar mimetizar o feitio de pedras preciosas foram escolhidas pedras de vidro. O vidro, diferente de outros materiais como o plástico, por exemplo, consegue preservar o brilho sem deixar o traje pesado, pois é um material relativamente leve. Nos trajes femininos, as pedrarias são bordadas em telas transparentes para que sejam imperceptíveis de longe. Segundo as orientações dos documentos sobre a primeira montagem - a chamada "Bíblia" do espetáculo - e segundo imagens da época, é possível que os trajes de Karinska fossem construídos com o mesmo tipo de pedraria.

O traje dos Rubis contava, tanto nos masculinos quanto nos femininos, com um detalhe no quadril, uma espécie de saia de tiras. A diferença é que nos trajes femininos havia ainda um detalhe embaixo das tiras, de cor clara. Muito mais vivo e com margem à mobilidade, esse traje é construído em tecido mais flexível. O traje era vermelho e dourado, com detalhes bordados no colo e nas pontas das tiras, que ficavam na altura do quadril. Esse traje continha menos bordados que os outros, possivelmente dado ao caráter mais moderno de sua movimentação.

Figura 34 - Patricia McBride e Edward Villella com os trajes de Rubi. (1967).

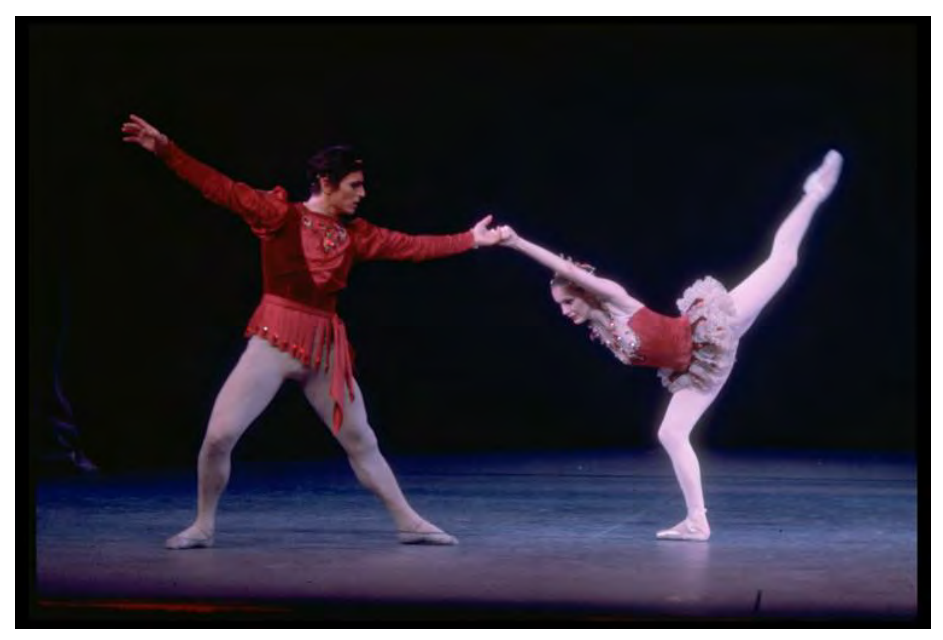

Fonte: New York Public Library ${ }^{45}$

Barton relata que além de esteticamente ricos, os detalhes das pontas das tiras tinham uma função de trazer um elemento sonoro. Quando os bailarinos se movimentavam, as tiras batiam umas nas outras, provocando um som que, ao longo da dança, acompanhava o ritmo da

\footnotetext{
${ }^{44}$ Disponível em: < https://www.youtube.com/watch?v=msLjmbPFmT4> Acesso em 25 Set. 2018.

${ }^{45}$ Disponível em: < https://digitalcollections.nypl.org/items/fd9788f0-1fdc-0132-1e72-58d385a7bbd0> Acesso em 25 Set. 2018.
} 
música. Isso era mais um elemento de alegria e excitação para esse ato, em consonância com a música e coreografia.

O que Karinska propõe com esse bordado é um potencial por vezes pouco explorado nos figurinos: a possibilidade de fazer com que eles produzam um som, ou ainda, que o som seja parte do figurino. É através do bordado que ela encontrou uma maneira de realizar essa ideia, ainda pouco explorada nos dias de hoje.

Por fim, o traje dos Diamantes conta com um tutu clássico, mais curto. Construído com cores claras - branco e off-white - muito elegante. O tecido do corpete é mais rígido, para tentar transparecer elegância e nobreza. As mangas são feitas em elástico quase transparente, fazendo com que de longe as pedras pareçam estar direto na pele. Inspirado pela Rússia Imperial, esse traje traz elementos comuns do período: os trajes claros com bordados brancos e prateados, comum em diversas imagens da família imperial e os detalhes em pedraria que pendiam do colo dos vestidos.

Figura 35 - Suzanne Farrell usando o traje Diamantes (1967).

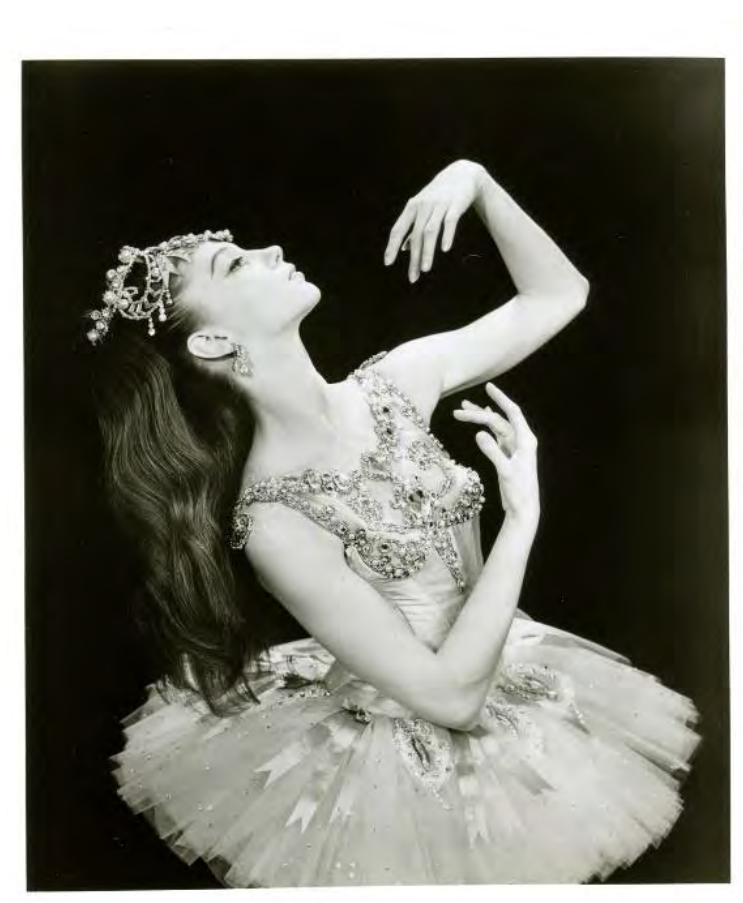

Fonte: Tumblr Juotin ${ }^{46}$

Além disso, todos os trajes contam com uma espécie de "pingente" nas saias, também para tentar mimetizar uma peça de joalheria. Os trajes criados por Karinska, além de muito

\footnotetext{
${ }^{46}$ Disponível em: <https://juotin.tumblr.com> Acesso em 18 Dez. 2017
} 
bonitos esteticamente, também foram confeccionados com tecidos muito duráveis com muitos cuidados. As partes de trás dos bordados são todas forradas, de modo que não entrem em contato com o suor da pele dos bailarinos. Esse forro tem a dupla função de promover conforto aos dançarinos ao mesmo tempo em que preserva os trajes.

Karinska também produziu bordados em trajes que, além de uma função decorativa, também ajudavam a moldar o corpo dos atores segundo a necessidade. É claro que o trabalho de um figurinista envolve lidar com corpos humanos, todos diferentes entre si, cada um com suas especificidades. Muitas vezes é preciso fazer opções estéticas que valorizem ou desvalorizem algo do corpo de um ator de acordo com a necessidade da história. De acordo com Viana (2016), foi isso que Karinska fez em alguns trajes de Os cenci, de Antonin Artaud:

Não se sabe exatamente por que Karinska colocou uma passamanaria delineando as linhas das musculaturas corporais, para ressaltar os músculos em todos os homens que usavam malha colante ao corpo. Acredito que a ideia por trás disso fosse ressaltar a rigidez desses homens através da musculatura, mas o elenco todo era muito magro. (...). Além disso, esse problema deve ter sido de última hora, porque não estava previsto nos desenhos originais de Balthus. (VIANA, 2016, p.174)

Figura 36- Antonin Artaud em cena em Os cenci (1935).

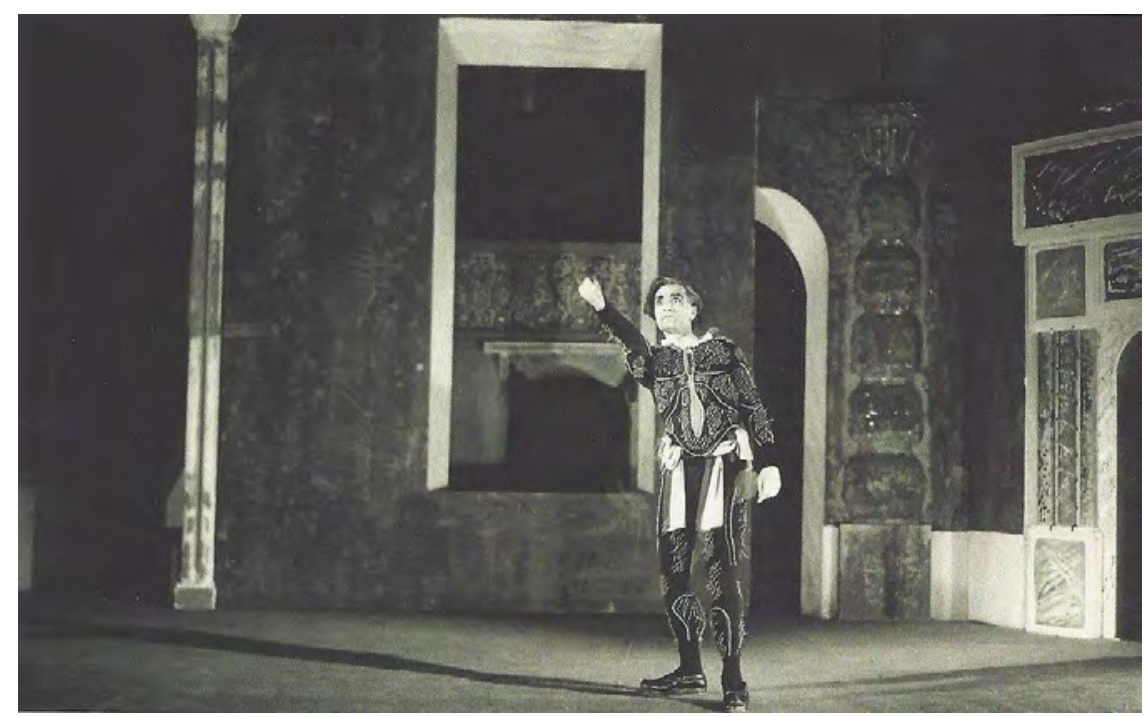

Fonte: Blog Heather Elton. ${ }^{47}$

É possível que Karinska, habituada a trabalhar no balé, onde os dançarinos costumam ser muito magros, tivesse dado essa solução posteriormente. Como não há esse registro nos

\footnotetext{
${ }^{47}$ Disponível em: <http://www.eltonyoga.com/vajrayogini/1990/08/20/antonin-artaud-a-man-possessed/>. Acesso em 15 Dez. 2017.
} 
croquis, o que deve ter acontecido é uma mudança já nas provas do figurino. Possivelmente o resultado das malhas não foi satisfatório e Karinska teve que pensar em alguma maneira de transformar aquele figurino de modo que os atores se sentissem confortáveis usando e a mensagem desejada pelos realizadores fosse passada.

\title{
1.3.2. Uso narrativo em Game of Thrones (2011)
}

Game of Thrones é uma série de TV produzida pela HBO, baseada na série de livros homônimos de G. R. R. Martin. A série estreou em abril de 2011, teve sete temporadas até o presente momento e conta a história de nove famílias disputando o poder de um reino. Cada família tem alguns elementos visuais que as distingue: cor, animal que a simboliza e estilos de se vestir. Esta análise se detém apenas na descrição das famílias importantes para a análise das personagens escolhidas. As famílias são: Stark (cor cinza; animal lobo gigante); Tully (cor azul; animal peixe); e Lannister (cores vermelho e dourado; animal leão).

Para Michele Clapton, figurinista da série ao longo de todas as temporadas exceto a sexta - quando o figurino foi assinado por April Ferry, era muito importante que os figurinos pudessem comunicar algo aos espectadores. Além de serem bonitos, os trajes deveriam comunicar sobre as personagens de alguma maneira. Segundo ela em entrevista ao site The Insider $^{48}$ :

\begin{abstract}
"Eu sempre tento contar uma história — os figurinos para mim são narrativos e devese poder olhar para eles e entender onde estão mentalmente na sua jornada. Eu acho que eles foram ganhando força e atingindo novas coisas." (CLAPTON, 2017, tradução nossa)
\end{abstract}

Foi no bordado que Clapton encontrou uma maneira subliminar de contar histórias nos trajes das personagens. Para isso, ela se uniu com a bordadeira e artista têxtil Michele Carragher, que trabalha tanto bordando diretamente sobre os trajes, quanto bordando em seda ou organza e posteriormente aplicando no local desejado do figurino. Segundo a própria Carragher em seu site oficial ${ }^{49}$, a escolha pelo bordado manual se dá principalmente pela maior flexibilidade e possibilidade de criação. O bordado à máquina para ela, tem uma limitação maior de cores, texturas, linhas e elementos. Quando se borda à mão, se pode utilizar maior diversidade de

\footnotetext{
${ }^{48}$ Disponível em: < https://www.thisisinsider.com/game-of-thrones-costume-designer-michele-claptoninterview-2017-6> Acesso em 25 Set. 2018.

${ }^{49}$ Disponível em: < http://www.michelecarragherembroidery.com/About(2829561).htm> Acesso em 25 Set. 2018.
} 
materiais que nem sempre a máquina suporta. Seu trabalho é sempre muito próximo ao do figurinista, que cria com ela os bordados.

Em Game of Thrones, os temas bordados são principalmente símbolos referentes ao universo da trama. O mais comum é que apareçam os animais que simbolizam as casas e famílias das personagens, bem como suas cores. Aqui o foco está em analisar exemplos de trajes de duas personagens: Sansa Stark e Cersei Lannister, cujos trajes parecem contar com bons exemplos de usos narrativos do bordado, tanto de maneira pictórica quanto de maneira simbólica.

Sansa Stark (Sophie Turner) é uma personagem que passa por diversos momentos que provocam transformações em sua personalidade. Ela começa a série como uma adolescente que se muda para o reino, onde seu pai fará parte do Conselho do Rei. Eles moram em um local muito distante e Sansa sonhava em conhecer o mundo. O que começa com a vida de uma personagem típica da inocência romântica, vai se tornando com o passar da história em um conflito sombrio: Sansa perde o pai e após a morte do rei é mantida refém pela Rainha Cersei Lannister (Lena Headey), primeiro como noiva do príncipe e depois como prisioneira; obrigada a casar com um homem da família real, Sansa acaba fugindo e passando por outra série de infortúnios até reencontrar seu irmão no antigo lar. Juntos, eles começam a retomar os terrenos de sua família. A personagem que parecia uma menina boba vai se tornando uma personagem forte e essa transformação se reflete fortemente em seus trajes.

Cersei Lannister é a rainha, uma mulher vinda da família mais rica de todo o reino. Casada num casamento de interesse com um homem violento, Cersei tem um caso com o próprio irmão, com quem tem três filhos. Quando o marido morre - num acidente causado por ela própria - Cersei investe na manipulação do filho mais velho, para que ele realize os interesses da família. Se antes ela havia tolerado o noivado de Sansa com seu filho, depois da morte do marido tudo muda de figura, pois seu filho é incontrolável, sádico e esse casamento já não seria vantajoso. Pouco a pouco tudo vai desmoronando para ela: um a um, seus filhos morrem, bem como seu pai; o irmão já não é mais fiel a ela; e o reino parece escapar por entre seus dedos. Assim como Sansa, todas essas transformações vão se revelando nas mudanças dos trajes da personagem com o passar da série.

Apesar de ser mais comum na série que as famílias sejam associadas unicamente a um símbolo, o da família do homem/pai, os trajes de Sansa comumente contam, além do símbolo da família do pai, o lobo gigante (Figura 37), com o símbolo da família de sua mãe também, o peixe (Figura 38). Essa opção não é gratuita e diz muito principalmente sobre a relação entre 
as personagens. Sansa sempre foi a filha mais próxima de sua mãe e tinha com ela uma relação de muita cumplicidade. Além disso, Sansa inicia a história com grande rejeição ao lugar onde mora. O local da família de seu pai é frio, distante e isolado, bem diferente daquilo que sonha para si. Sansa deseja morar no reino, onde se passam as histórias que ouvia na infância. A presença concorrente do peixe nos trajes mostra um traço da personalidade da personagem: sua ligação está muito mais com a mãe do que com o pai.

Figura 37- Detalhe de lobo bordado em traje de Sansa.

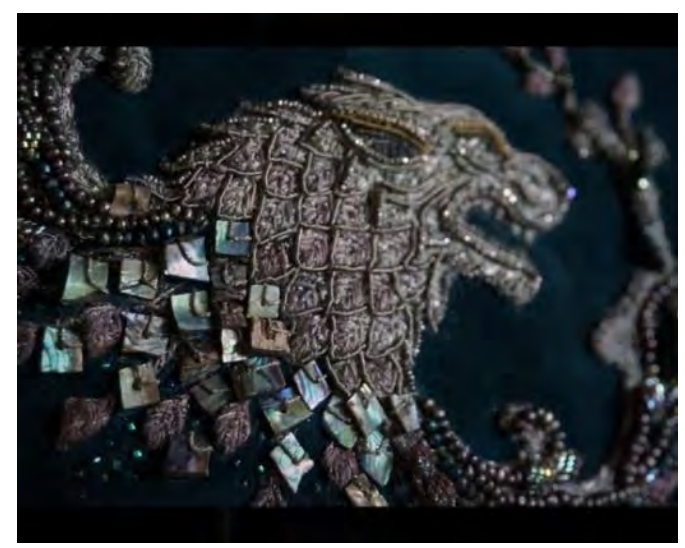

Fonte: Site Michele Carragher ${ }^{50}$
Figura 38 - Detalhe de peixe bordado em traje de Sansa.

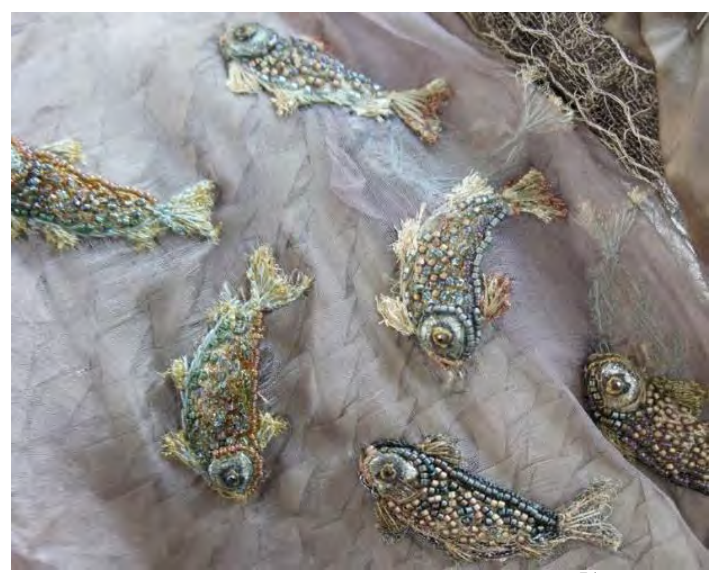

Fonte: Site Michele Carragher ${ }^{51}$

Cersei tem um movimento parecido em suas roupas. Ainda que seja comum uma predominância dos símbolos dos chefes de família nos trajes, Cersei raramente usava o símbolo da família do marido. Enquanto ele esteve vivo, a única peça assim que usava era a coroa de rainha, feita com o formato dos chifres de um veado; assim mesmo, a peça foi usada apenas enquanto não era viúva. No mais, todos os seus adereços sempre são voltados para o símbolo de sua família, o leão.

O símbolo da família de Cersei não aparece tão óbvio num primeiro momento. Na primeira temporada - e em alguns momentos da segunda - quando Cersei ainda está presa num casamento infeliz, pouco se vê das cores de sua família ou do leão. Naquele momento, a personagem ainda precisava fingir uma subserviência e passividade que na verdade não possuía. Talvez por isso, nesse primeiro momento, seus trajes sejam costumeiramente adornados com bordados de pássaros. Assim como eles, ela estava presa sem poder alçar vôos próprios. Além

\footnotetext{
${ }^{50}$ Disponível em: < http://www.michelecarragherembroidery.com/Season-6-Gallery(3038040).htm>. Acesso em 15 Dez. 2017.

51 Disponível em: <http://www.michelecarragherembroidery.com/Game-of-Thrones-Gallery(2829575).htm> Acesso em 25 Set. 2018.
} 
disso, ela não tinha outra função que não a de ser bela, como uma espécie de decoração. É possível que por essa razão esses trajes contem muito com referências ao bordado sashiko ${ }^{52}$ : ela também estava numa situação em que se sentia quebrada e precisava encontrar um modo de se fortalecer consertar sua vida.

Um dos trajes mais simbólicos desse momento da história da personagem é o vestido azul com bordados de pássaros (Figuras 39 e 40). Esse traje é usado duas vezes na primeira temporada de Game of Thrones e mais algumas vezes na segunda temporada. Na primeira, nos momentos em que o usa, Cersei está mostrando seu lado mais atrelado às fragilidades e dificuldades dos papeis sociais de gênero: quando é a mãe, que dá conselhos e consola o filho, o ensinando que os reis muitas vezes não fazem exatamente sua vontade, mas sim o que é preciso fazer para assegurar sua posição; e quando é a esposa sem importância, que junto ao marido ao fazer uma acusação a seu conselheiro, não só não tem suas demandas atendidas, como também é agredida fisicamente.

Figuras 39 e 40 - Vestido Azul de Cersei (2011).
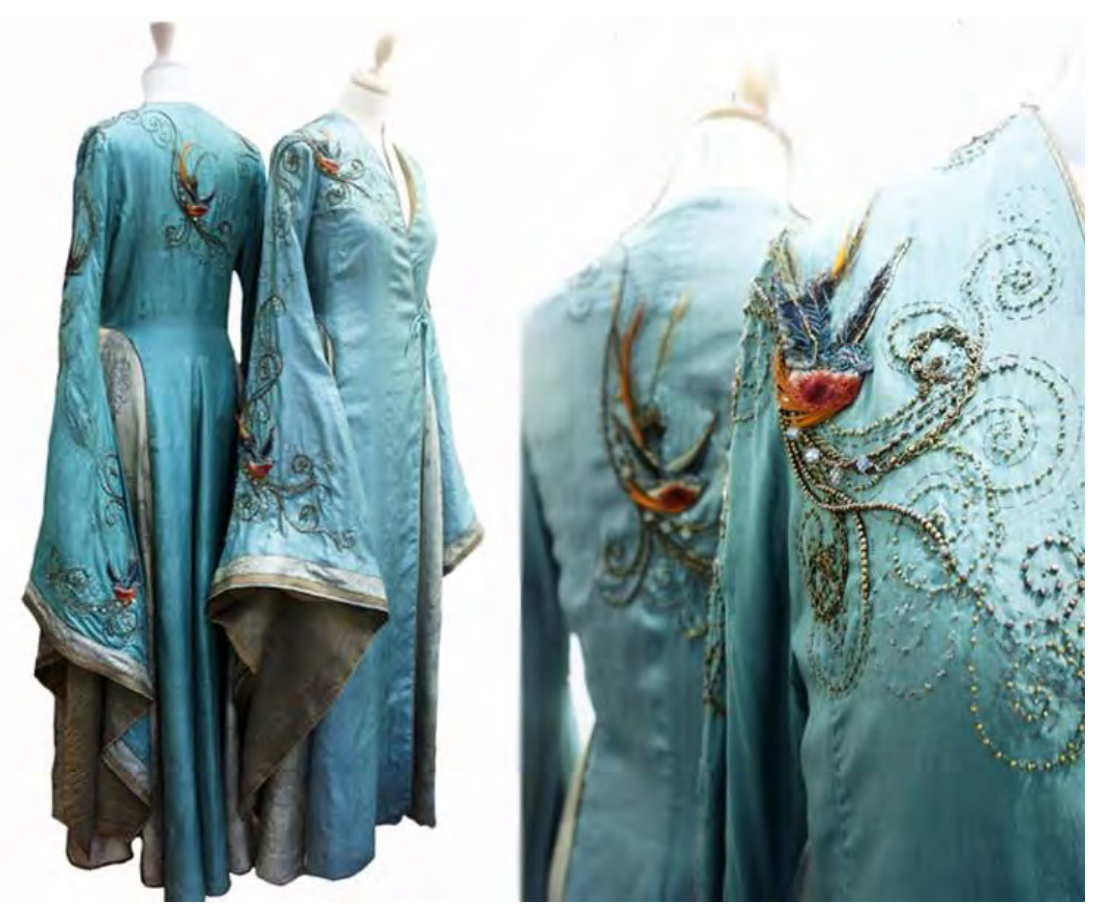

Fonte: Site Michele Carragher ${ }^{53}$

\footnotetext{
${ }^{52}$ Sashiko é uma técnica de bordado japonesa que tinha duplamente a função de adornar e reforçar as costuras dos trajes. É um bordado funcional: quando as roupas rasgavam ou precisavam de remendos e retalhos, utilizava-se o sashiko para juntar os pedaços de maneira bonita e decorativa. É feito com pontos corridos, como uma espécie de alinhavo.

53 Disponível em: <http://www.michelecarragherembroidery.com/Game-of-Thrones-Gallery(2829575).htm>. Acesso em 14 Dez. 2017.
} 
Na segunda temporada, esse traje aparece também em momentos que Cersei está se sentindo coagida ou impelida a situações que a desagradam, mas que não a deixam ver outra saída: no dia em que precisa começar a reorganizar o reino após a morte de seu marido e do conselheiro real e, diante de um conselho, não é levada a sério e tem sua posição no governo tomada por seu irmão mais velho - com quem não tem uma boa relação - e sempre que eles discutem à sós; e no dia em que sua filha está sendo enviada para outro reino, como parte de um acordo entre as famílias para garantir apoio político, próxima a seu irmão como uma sombra, contrariada e infeliz pela situação. Como ela, sua filha também está sendo utilizada como peão em alguma manobra para garantir poder.

O símbolo do pássaro em Cersei está sempre associado a momentos de falta de poder, em que ela alterna entre o ser frágil e o ser que só existe para ser admirado. Não parece estranho, portanto, que ela chame Sansa de little bird. Ela vê na menina sozinha, colocada à disposição para casar com o rei, sem aparente vontade própria alguma, uma imagem de si própria com tudo aquilo que deseja evitar e se desvencilhar. Quando ela adquire mais poder e se torna mais segura de sua posição no governo, os trajes mudam. Além da presença mais expressiva do símbolo e cores de sua família, se chega a ver também trajes com bordados em que se vê um leão se sobrepondo a um pássaro, por vezes o engolindo e por vezes o cobrindo visualmente.

A própria Sansa ganha contornos de aprisionamento e fragilidade de maneira paralela visualmente, mas o símbolo que fica bordado em seus trajes é o da libélula. A primeira vez em que aparecem trajes com esse motivo bordado é durante o processo de execução de seu pai, na época conselheiro do rei. Tanto no momento em que está pedindo misericórdia pela sua vida quanto no momento da execução em si, Sansa traja um vestido de cor clara com bordados de uma libélula. Durante todo o tempo que está aprisionada pelos Lannisters no reino, esse motivo aparecerá de alguma maneira, pois além dos bordados, Sansa também usa um colar com pingente de libélula o tempo todo e, assim como nos vestidos de Cersei, o sashiko volta a aparecer.

Pensando particularmente no bordado como narrativa simbólica, tanto o vestido azul de Cersei como os breves detalhes apontados dos trajes de Sansa parecem bons exemplos desse uso, pois é justamente o contexto das personagens quem nos dá as ferramentas para ler aquilo que o traje está querendo dizer e entendê-lo. Sansa, por exemplo, é uma personagem desde o início apresentada como alguém dotada de habilidades manuais. São recorrentes as cenas em que a personagem é vista bordando, costurando, etc., sendo que a primeira cena em que 
conversa com Cersei esse é justamente o tópico da conversa. Segundo Clapton em entrevista ao Buzzeed ${ }^{54}$ :

\begin{abstract}
"Ela se expressa através de sua habilidade para bordar e costurar. Mesmo nas primeiras cenas, Cersei pergunta onde ela conseguiu seu vestido e ela diz que ela mesma o fez. Então nós sempre os usamos como algo que Sansa poderia expressar seus sentimentos - através dos bordados e motivos de seus trajes e através dos tons e cores." (CLAPTON, 2016, tradução nossa)
\end{abstract}

Outro elemento narrativo simbólico dos bordados em Game of Thrones é sua posição nos trajes. A maioria dos bordados dos trajes de Cersei, por exemplo, se encontram nos ombros e costas, formando uma espécie de proteção e, por vezes, uma espécie de armadura. Além disso, são vistos imediatamente por aqueles com quem ela interaja, deixando sempre claro, assim, seu poder e posicionamento diante das situações. Foi se tornando muito comum ao longo do tempo que sempre que fosse se envolver num embate político, Cersei usasse trajes com bordados mais ricos e intrincados. Isso também era uma forma de reafirmar seu poder e lembrar àqueles com quem estava que não só ela era a rainha, como também membro da família mais rica do reino.

Já a composição do vestido de casamento de Sansa Stark apresenta outro tipo de narrativa utilizando os bordados. Michele Clapton elaborou o vestido com uma faixa que se enrolava em torno do corpo da personagem, quase que a mantendo presa. Essa faixa seria bordada com elementos e desenhos que contassem simbolicamente a trajetória da personagem até então: desde sua vida na casa de sua família, até a chegada ao reino e seu enlace com a família Lannister. Para isso, Michele Carragher começou o bordado com os dois símbolos que representavam a família de Sansa: o peixe, símbolo da família de sua mãe, e o lobo gigante, símbolo da família de seu pai (Figura 41). Não por acaso, esses símbolos foram bordados na parte de trás do vestido: a vida com sua família era aquilo que Sansa estava deixando para trás.

Conforme a faixa vai contornando o corpo da personagem, se percebe que o leão, símbolo da família de seu futuro marido, vai se tornando predominante e começa a sobrepor os símbolos anteriores (Figura 42). Ele chega ao ápice na parte de trás do pescoço, como um peso que a personagem vai carregar a partir de agora. No pescoço do vestido, se encontra um imponente leão, com uma coroa sobre a cabeça (Figura 43). Para a família Lannister é muito importante ressaltar que eles são aqueles que estão no trono e, portanto, que estão vencendo a

54 Disponível em: <https:/www.buzzfeed.com/keelyflaherty/facts-about-the-game-of-thrones-costumes-youprobably-nev> Acesso em 25 Set.2018. 
disputa. Por isso, a maior parte das vezes em que o leão aparece bordado em alguma personagem, ele está ostentando uma coroa ou outro elemento que deixe claro seu status.

Figura 41 - Detalhe da parte de trás do vestido

de Sansa.

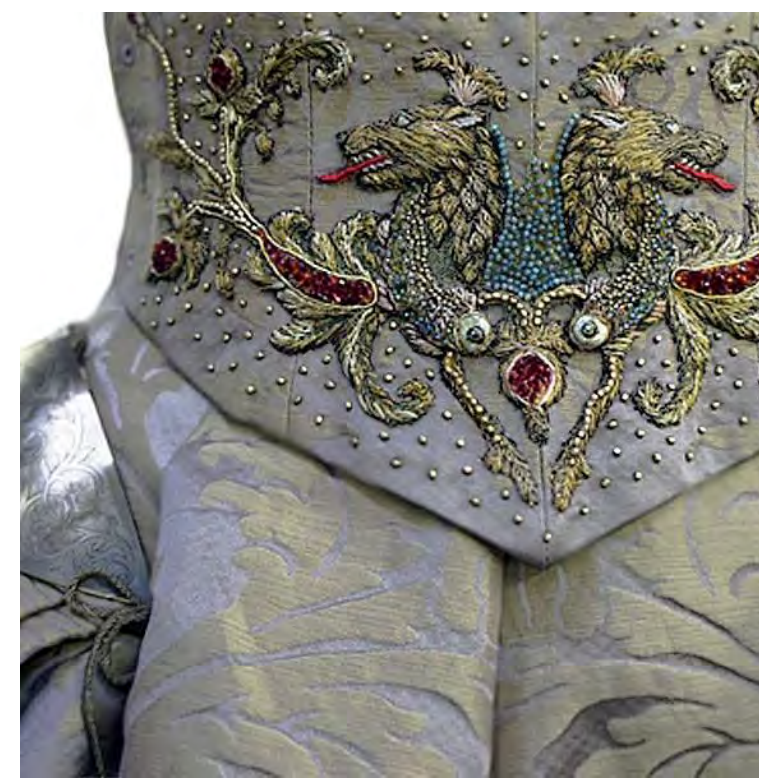

Fonte: Site Michele Carragher ${ }^{55}$
Figura 42 - Detalhe da lateral do vestido.

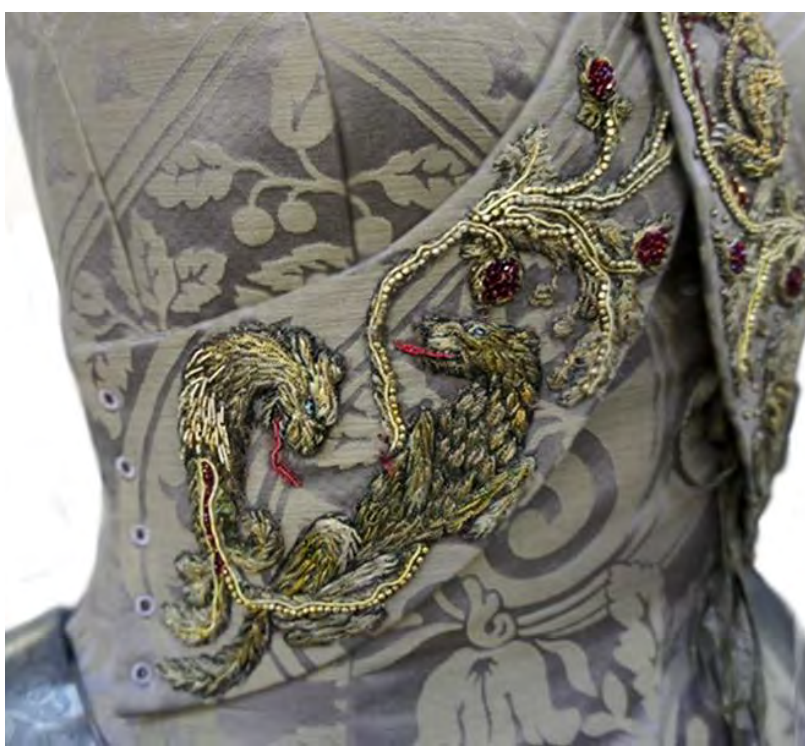

Fonte: Idem $^{56}$

Figura 43 - Detalhe do pescoço do vestido.

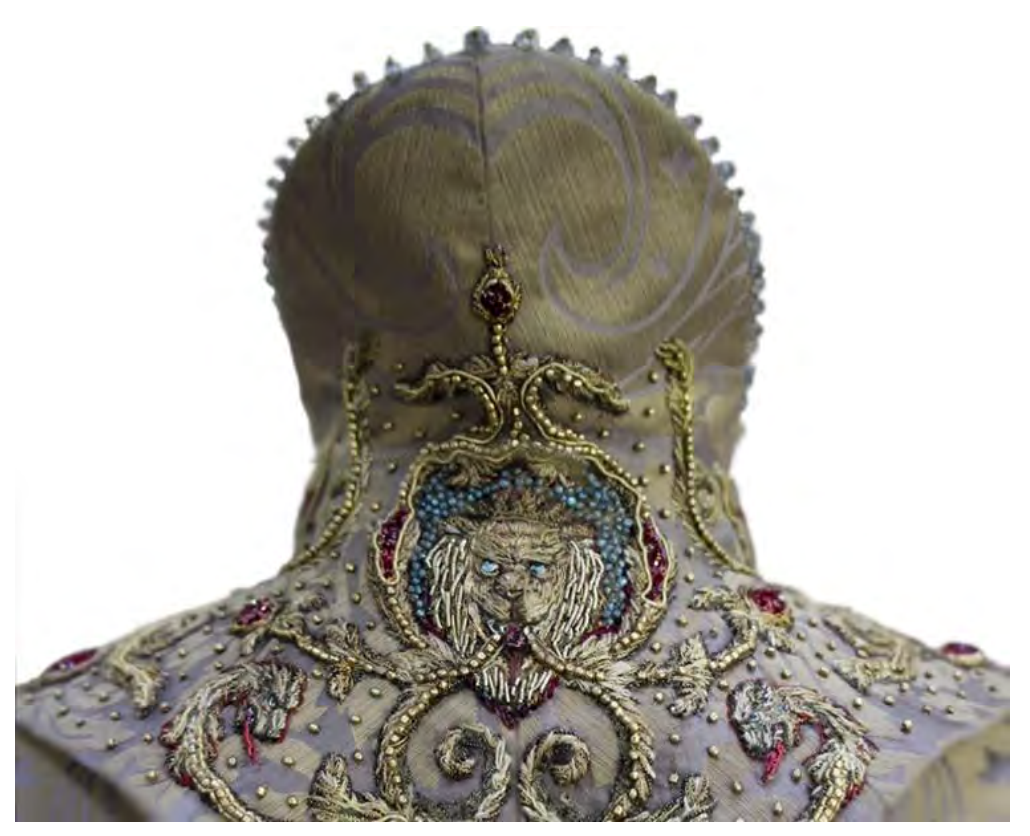

Fonte: $\operatorname{Idem}^{57}$

\footnotetext{
${ }^{55}$ Disponível em: <http://www.michelecarragherembroidery.com/Sansas-Wedding-DressGallery(2880131).htm>. Acesso em 13 Dez. 2017.

56 Idem.

${ }^{57}$ Idem.
} 
As cores do vestido também são muito simbólicas. A base do vestido é feita de um tecido brocado que mistura as cores cinza e dourado. O cinza é a cor de sua família e, por isso, sempre acessada em momentos que a personagem precisa demonstrar claramente sua ligação com suas origens. Aqui, porém, é perceptível que o cinza está sendo tomado pelo dourado da estampa, tornando as cores mescladas. O dourado é uma das cores da família Lannister, logo, fica expresso na própria escolha do tecido a crescente influência e dominação da família do marido sobre Sansa. Além disso, Carragher optou por fazer o bordado todo do vestido em dourado, com crescentes acréscimos do vermelho, também para simbolizar a influência dos Lannisters sobre Sansa se tornando cada vez mais expressiva.

O que se vê aqui é quase um storyboard: passo a passo, as imagens vão retratando momentos de uma história. Ainda que exija o mínimo de conhecimento do contexto da série principalmente dos símbolos e cores que representam cada família - esse traje apresenta uma história de fácil compreensão e disposição linear e sucessiva dos fatos, o que o coloca como um exemplar de uso narrativo pictórico do bordado. 
Capítulo 2

Estudos de caso: Bispo do Rosário, bordados e o teatro 


\subsection{Arthur Bispo do Rosário}

Tudo o que há no amor, no crime, na guerra ou na loucura nos deve ser devolvido pelo teatro, se ele pretende reencontrar sua necessidade. (Antonin Artaud, O teatro e seu duplo)

Defende Artaud em seu conhecido texto Van Gogh: o suicidado pela sociedade que a loucura é uma fuga às opressões da vida. Se Van Gogh perdeu sua lucidez, foi por tentarem encaixa-lo nos padrões, por tentar curá-lo de sua genialidade. O encenador não deixava de se identificar com esta figura. Artaud passou boa parte da vida sendo submetido a tratamentos que supostamente o livrariam das crises que atormentavam seu espírito. Nunca conseguiu livrar-se delas e passou a vida sendo visto como louco.

A imagem do artista gênio-louco é uma figura comum na sociedade. O artista genial e incompreendido que acaba sendo considerado mentalmente desequilibrado remete a muitas personagens da história. Se os conceitos que definem loucura são discutíveis, se torna menos fácil discordar da genialidade de artistas que produzem obras sob condições psíquicas instáveis. A relação entre arte e loucura traz narrativas diferentes das consideradas oficiais da psiquiatria e, muitas vezes, ganha traços místicos.

Viana (2016) diz que a dificuldade em pesquisar Artaud está justamente em se desvincular da aura mítica que lhe foi impingida com o tempo. $\mathrm{O}$ artista apresentado aqui também conheceu sua parcela de "mito". A história de Arthur Bispo do Rosário, lendária ou não, é bastante conhecida ${ }^{58}$. Com passagens pela Marinha Brasileira no Rio de Janeiro e pelo boxe amador, em 1938 sofre um delírio místico em que é conduzido por um exército de anjos e anda pelas ruas do Rio de Janeiro para se apresentar na Igreja da Candelária. No caminho até lá, passa por outras igrejas, encontrando com padres e fieis, e afirmando a eles que era um enviado, incumbido de "julgar os vivos e os mortos".

Depois disso, ele é diagnosticado como esquizofrênico-paranóico e é internado na Colônia Juliano Moreira. No início dos anos 1960, depois de muitas curtas passagens pela Colônia, é internado definitivamente e lá permanece até sua morte em 1989. Nos seus períodos internado, Bispo produziu cerca de 800 obras de arte, sempre partindo de objetos do cotidiano.

\footnotetext{
${ }^{58}$ O livro Arthur Bispo do Rosário - o senhor do labirinto, de Luciana Hidalgo (2012) é uma das biografias mais completas do artista. As passagens detalhando sua vida e acontecimentos de sua história presentes nesta pesquisa foram todos selecionados a partir dessa obra.
} 
Uma das principais técnicas empregadas por Bispo na confecção de suas obras foi o bordado. Ele produziu um grande número de obras que contavam principalmente com escritas e desenhos muito variados e detalhados em tecidos. Por se encontrar dentro de um espaço de onde não tinha permissão para sair, Bispo encontrava maneiras de aproveitar e ressignificar elementos de seu cotidiano para confeccionar matéria prima e, depois, obras de arte a partir delas. Segundo Hidalgo:

De início, na falta de material, Bispo teria desfiado o próprio uniforme azul da Colônia para reaproveitar os fios em seus bordados. Desmanchou toda a veste, aproveitou linha a linha e deu início à teia que abrigaria os lotes de seu novo mundo. Ao desfazer o próprio uniforme, desconstruía um dos grandes símbolos do poder psiquiátrico e reutilizava a matéria-prima para construir seu universo paralelo, a sua utopia. (HIDALGO, 2012. P.12)

\section{Figura 44 - Arthur Bispo do Rosário}

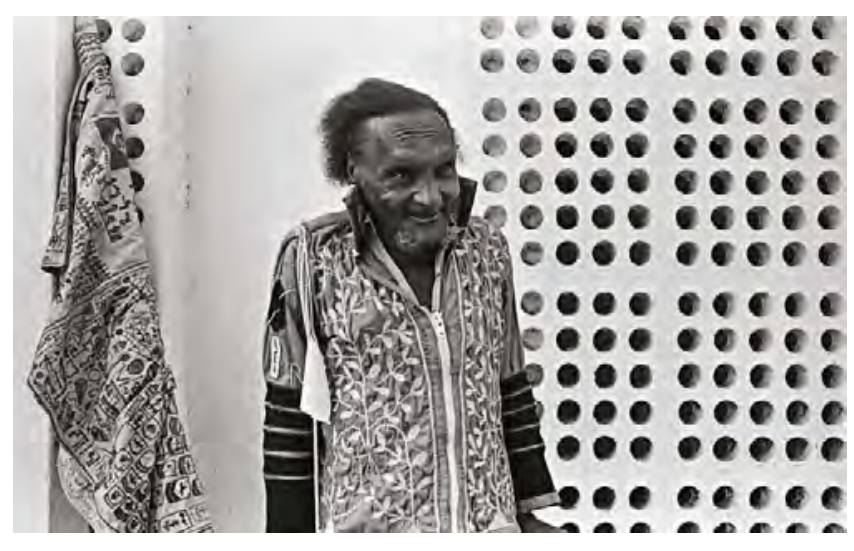

Fonte: Geledés ${ }^{59}$

Não à toa o azul é uma das cores mais importantes e mais presentes na obra de Bispo. Possivelmente este era o material que possuía em maior abundância, já que os uniformes dos internos da Colônia eram desta cor. Além disso, presume-se que ele tivesse proximidade com esta cor dado que sua passagem pela marinha - cujos uniformes também possuíam a cor azul é uma referência constante em seus bordados.

Sua proximidade com o bordado já era notada antes mesmo de sua internação. As pessoas com que convivia relatavam sua "obsessão por agulhas e novelos" (Idem) e como todo o pouco dinheiro que ganhava era gasto em armarinhos em busca de elementos que pudessem ser transformados em arte. É que alinhavar toda uma existência dava muito trabalho. E exigia toda a linha disponível no mundo dos homens. (Idem)

\footnotetext{
${ }^{59}$ Disponível em: < https://www.geledes.org.br/bispo-rosario-e-sua-arte-de-enlouquecer-os-signos/> Acesso em 26 Set. 2018.
} 
Neste trabalho, o foco está nas obras têxteis de Bispo do Rosário, principalmente nos trajes produzidos por ele. Além de uma das suas obras mais conhecidas, o Manto da Apresentação, também serão analisados os trajes de inspiração militar criados pelo artista.

\subsubsection{Apresentação do manto: o folguedo}

Arthur Bispo do Rosário nasceu com nome carregado de religiosidade em uma cidade repleta de rituais próprios. Japaratuba, em Sergipe, é um lugar que até hoje mantém suas tradições, principalmente aquelas ligadas aos grupos folclóricos e ao artesanato. $\mathrm{O}$ artesanato têxtil é muito popular e uma habilidade passada na família, de pais para filhos, sem distinção de gênero. Os artesãos produzem peças dos mais variados tipos como ${ }^{60}$ : telas, rendas, tricôs, crochês, bordados, rendendê ${ }^{61}$, ponto cruz, crivo ${ }^{62}$, linho, tecelagem, rede de pesca e jereré ${ }^{63}$

Japaratuba era uma cidade muito católica, mas que carregava alguns sincretismos religiosos. Além das tradições do calendário cristão, ainda se comemoravam folguedos ligados à religião, como a Folia de Reis. Pode-se assumir que Bispo cresceu cercado de pessoas que dedicavam seu tempo e habilidades à fé, construindo trajes e estandartes com as próprias mãos para honrar os dias santos. As comemorações para um dia santo começam semanas antes, com os preparos e costuras de trajes que misturavam as referências dos colonizadores do passado, com as dos indígenas e negros. Os usos do bordado nos folguedos foram, para Hidalgo (2012), essenciais para a construção da poética têxtil de Bispo do Rosário:

Os bordados eram a mais bem-acabada tradução da cultura matuta. Agulhas abriam trilhas em pontos de cruz e redendês, a formar desenhos, salpicar brilhos. Fantasias prontas, todo Dia de Reis, 6 de janeiro, grupos folclóricos as vestiam e dançavam pelas ruas de Japaratuba em atenção ao nascimento de Jesus e aos reis magos. O clímax dos folguedos era a coroação do rei e da rainha, obrigatoriamente negros, metidos em vestes cravejadas de bordados e franjas. Toda uma estética acondicionada na memória de Bispo, latente em suas obras, variações de um mesmo tema. (HIDALGO, 2012, p. 19)

\footnotetext{
60 Dados disponíveis em <https://www.guiadoturismobrasil.com/cidade/SE/628/japaratuba> Acesso em 15 Jun.2018.

${ }^{61}$ Rendedê é uma renda de agulha que consiste em tipo de bordado sobre linho, com pontos cheios e abertos, formando desenhos geométricos.

62 Renda de agulha; sobre base do tecido desfiado na largura e no comprimento de forma intercruzada, formando áreas cheias e vazias, com aspecto de crivo, se executa em forma de labirinto.

63 Armadilha de pesca composta de rede afunilada de malha trançada que se prende a um aro frequentemente provido de cabo, usada sobretudo para pesca em águas rasas e para apanhar crustáceos e peixes miúdos.
} 
Um dos folguedos que HIDALGO destaca é a Chegança. Segundo a Associação de Folguedos Populares de Alagoas ${ }^{64}$, a Chegança é um auto que se dedica a uma temática marítima e é ligada ao ciclo de Natal, ou seja, costuma acontecer no fim do ano. Pode versar sobre temas vinculados à vida no mar sob diversos aspectos, desde tempestades até as lutas entre os cristãos e os mouros na Europa. Ainda segundo a AFPA, possivelmente deriva das Mouriscadas Peninsulares, danças que interpretavam lutas, ou de uma potencial reinterpretação das Mouriscadas Europeias.

Figura 45- Rei Mouro em uma Chegança (Fotografia: Rosilda Cruz)

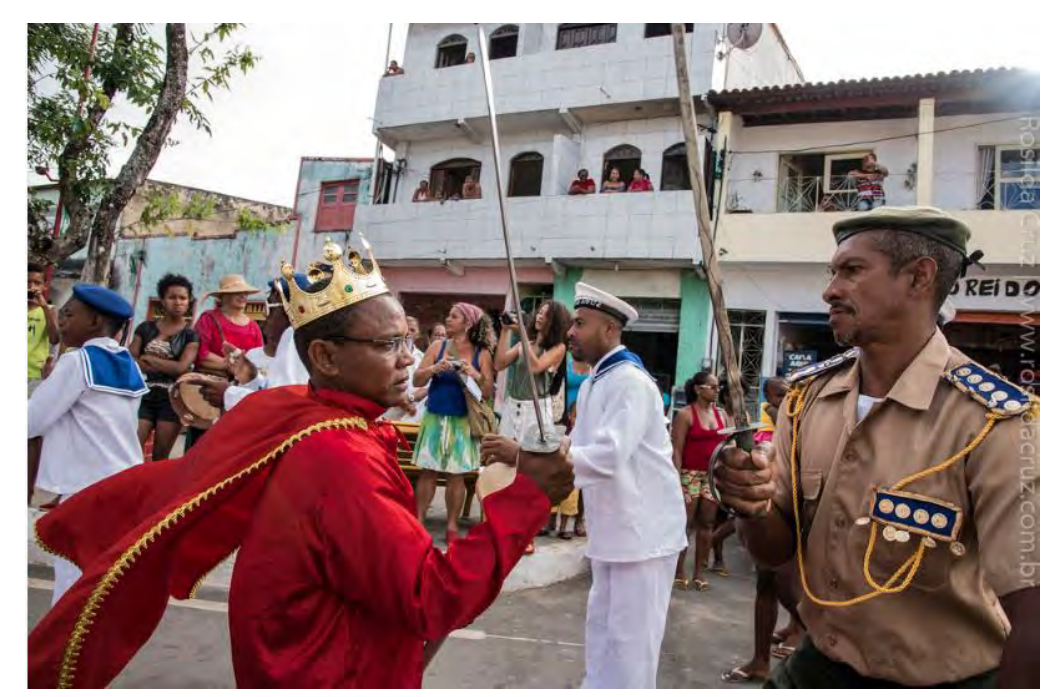

Fonte: Picssr ${ }^{65}$

Há, portanto, dois grupos que duelam entre si: os cristãos e os mouros. Cada grupo se veste de maneira diferente. O grupo dos cristãos se vestem com trajes que replicam os trajes da Marinha, nas mais diversas funções - pode-se encontrar desde grumetes a oficiais. Já os mouros, em bem menos número, costumam aparecer com trajes em tons fortes compostos de calças, camisas e capas. Todos eles portam espadas e, por vezes, instrumentos musicais com os quais tocam as músicas do auto. Entre os mouros, a personagem mais importante é a do Rei Mouro. O principal guerreiro da batalha encenada vem de coroa e, para indicar sua nobreza com ainda mais força, vem trajado de vermelho - cor costumeiramente associada à realeza. Seu manto era frequentemente adornado com muitos bordados e adornos dourados.

Talvez por isso, o Manto da Apresentação (Figuras 46 e 47), possivelmente a obra mais conhecida de Bispo, apresente a cor vermelha, como referência ao rei mouro da Chegança. Bispo, filho de uma família de ex-escravos, marginalizado pela sociedade, se reimagina o rei

\footnotetext{
${ }^{64}$ Disponível em: < http://asfopal.blogspot.com/p/folguedos.html> Acesso em 20 Jun.2018.

${ }^{65}$ Disponível em <http://picssr.com/search/chegan\%C3\%A7as/page2> Acesso em 29 Set.2018.
} 
ao mesmo tempo que se imagina filho de Deus através de uma veste com signos semelhantes ao do folguedo. Segundo Hidalgo (1996):

Egresso de uma vila cravada por tradições seculares, Bispo lidou das mais criativas formas com a diversidade de fardões, tecidos, adornos, rebordos costurados por mães, tias, avós. Ao se designar rei dos reis, teceria um manto avermelhado só para ele, salpicado de bordados, e se faria coroar, protagonista da própria via sacra. (HIDALGO, 1996)

Talvez esses mantos bordados da Chegança tenham sido uma referência escondida na memória de Bispo do Rosário para a criação do Manto da Apresentação. Há a presença de condecorações e dragonas, além de franjas douradas e cordas que cruzam o tecido. As cordas partem do centro do tecido, de uma mão branca bordada, como se dela emergissem tudo que há no mundo. O Manto é bordado tanto do lado externo quanto do lado interno. No exterior, há muitas cores e pequenas imagens, talvez remetendo a momentos importantes de sua vida: bandeirolas, como as que empunhava quando trabalhava na Marinha como sinaleiro-chefe; um ringue de boxe, referência a seu tempo de lutador; fora outros desenhos de objetos do cotidiano, como "tabuleiro de xadrez, peça de dominó, dado, mesa de sinuca, mesa de pingue-pongue, cesta de basquete, bicicleta, avião, trilho de trem, um objeto circular feito mandala, fogão, lambreta, escada, tesoura" (Hidalgo, 2012, p. 70) e números e palavras que muitas vezes não fazem sentido imediato àquele que vê a obra.

No lado interno, um labirinto de letras em azul. Os nomes que vinham escritos no avesso do Manto da Apresentação não foram pensados para serem vistos, mas sim para serem mostrados a Deus no Juízo Final. Ali se encontravam nomes - majoritariamente femininos - de pessoas conhecidas de Bispo por quem ele intercederia, pois as julgava merecedoras de subir ao céu. Segundo ele: "Eu vim para salvar a humanidade, então tenho que ter esses mantos de Cristo, bordados com os nomes de quem vai se salvar quando acabar o mundo" (BISPO DO ROSÁRIO apud HIDALGO, 1996). Não por acaso se encontram no lado de dentro do traje. De maneira ritual, Bispo trazia junto a si aqueles que eram merecedores da salvação, pois era ele próprio um intercessor divino.

O Manto foi uma obra criada ao longo da vida, concomitantemente com outras obras. O artista parecia desejar registrar sua própria trajetória cobertor que servira de base para a construção do manto. Segundo Figueiredo (2010):

O mistério presente na riqueza dessa peça, comparada com o acervo do artista, é impactante pelo zelo e pela visível atenção dispensada à sua elaboração. A presença de variadas cores de linhas no bordado do Manto da Apresentação em nada se assemelha aos demais bordados de Bispo do Rosário, tanto nos estandartes e como 
em outras vestimentas, onde existe a predominância do azul desfiado do uniforme da Colônia. A precariedade não teve oportunidade de se destacar no Manto. Ele é nobre, é fruto de uma incontestável seleção de materiais. Arthur Bispo do Rosário estava bordando algo para além do pano, inscrevendo algo definitivo, era como se estivesse tatuando um novo mundo na pele do Manto, um "ponto fixo" num mundo conturbado. (FIGUEIREDO, 2010, p. $99-100$ )

A bem da verdade, o Manto da Apresentação não foi criado para ser uma obra de arte, mas sim um traje funerário. Era uma espécie de traje sagrado, a mortalha com que faria a passagem. Por fim, Bispo do Rosário não foi enterrado com o Manto da Apresentação após sua morte. Seu rito funerário não se completou pois, na época, considerou-se que era mister preservar o valor artístico da obra ao invés do desejo do artista. Este é o principal debate ético em torno desta obra. Caso a vontade de Bispo tivesse sido respeitada, não seria possível hoje que estudasse com profundidade a obra de artista e toda a sua influência e importância para as artes plásticas no Brasil do séc. XX.

Figura 46- Manto da Apresentação.

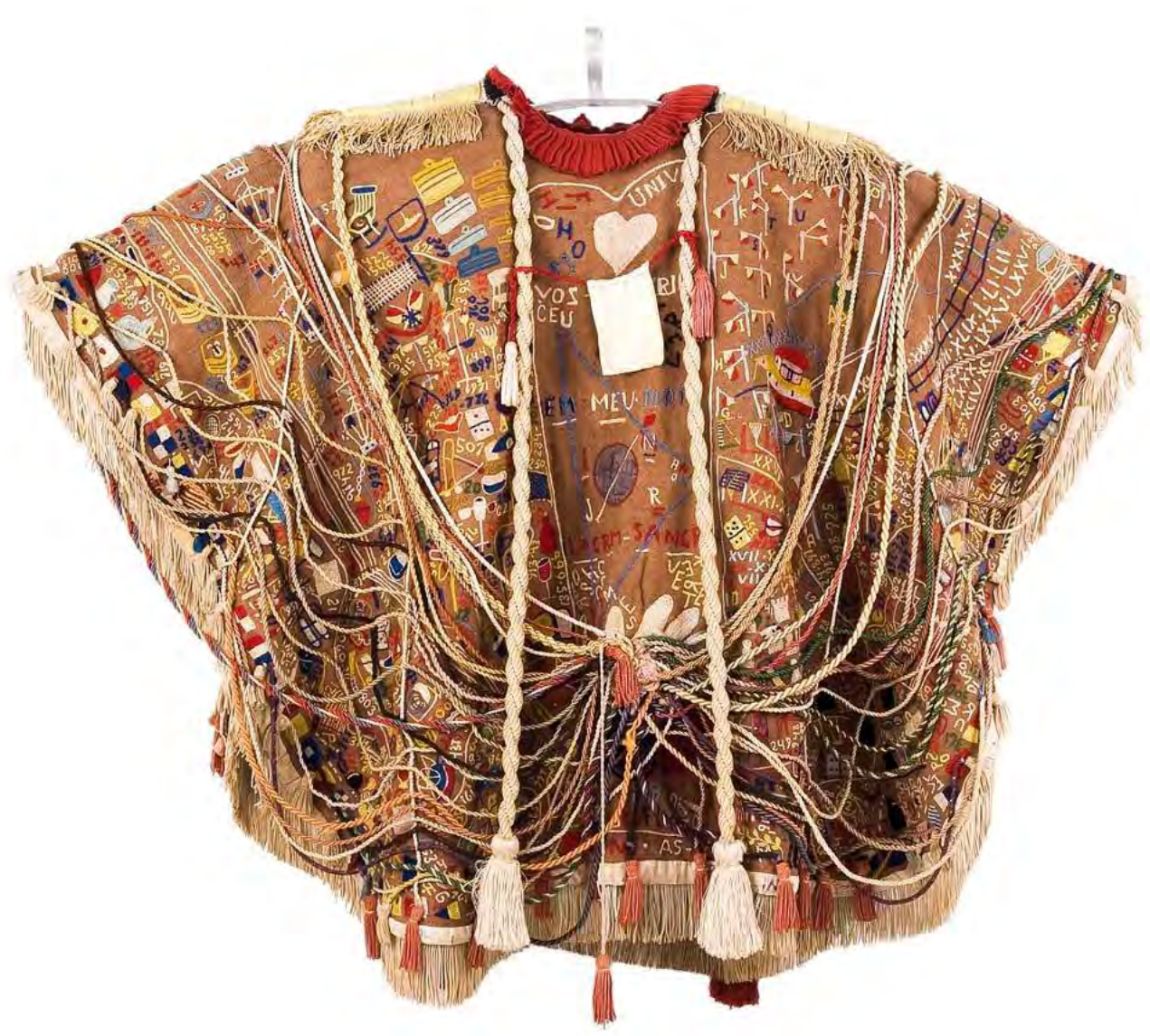

Fonte: Site Obvious Mag ${ }^{66}$

\footnotetext{
${ }^{66}$ Disponível em $<$ http://lounge.obviousmag.org/anna_anjos/2012/11/bispo-do-rosario.html $>$ Acesso em 15 Jun.
} 2018. 
Figura 47 - Visão interna do Manto da Apresentação.

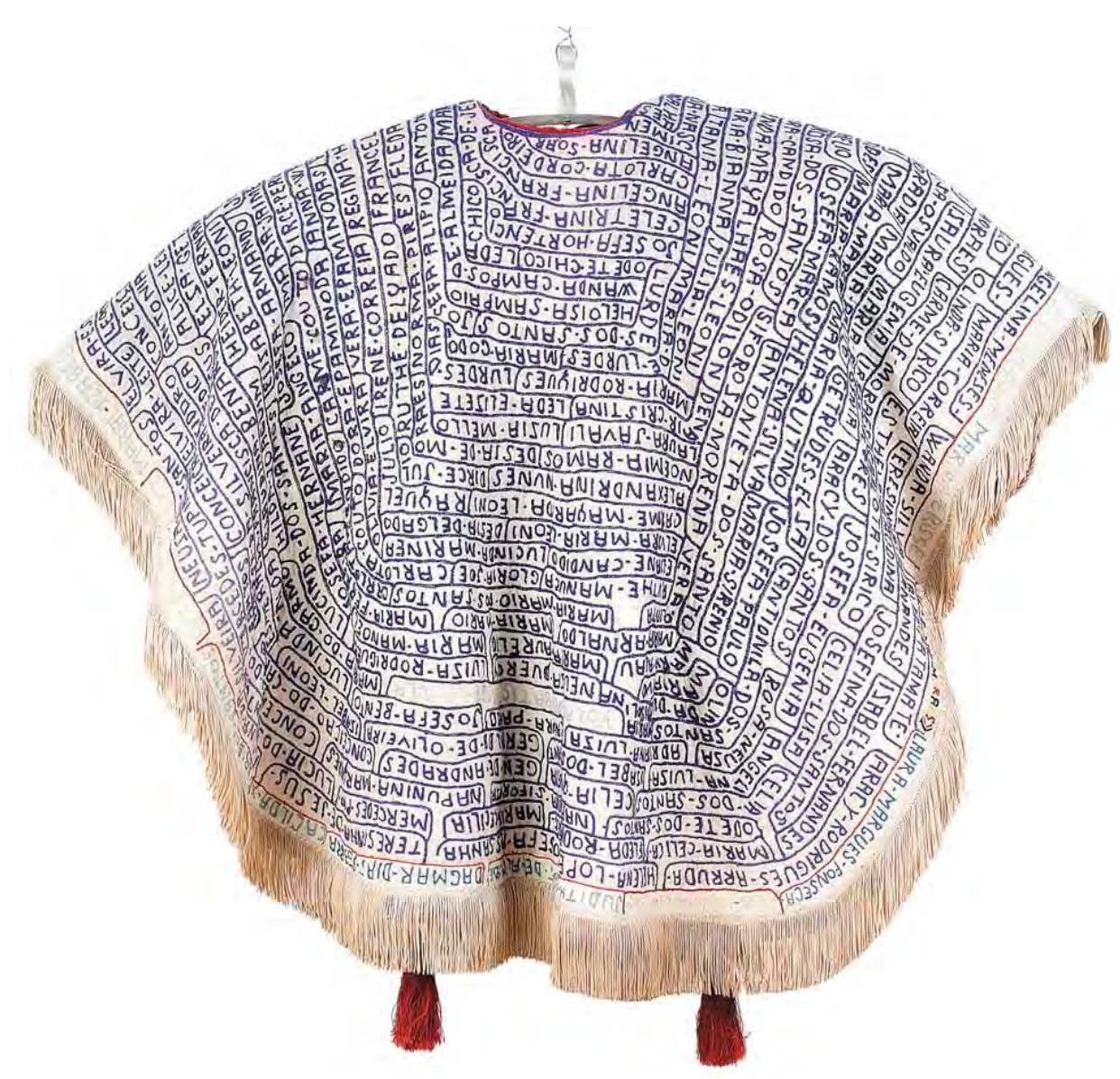

Fonte: Jornal GGN ${ }^{67}$

\subsubsection{Ulisses-Penélope: a marinha}

A Odisséia de Homero é construída com a costura de duas histórias: Penélope e Ulisses. Penélope era casada com Ulisses, Rei de Ítaca, há pouco tempo, quando começou a Guerra de Tróia. Ao fim da longa guerra, Penélope esperava que Ulisses retornasse, mas isso demorava a acontecer. Diante disso, diversos pretendentes passaram a importuná-la para que se casasse novamente. Ela então elabora um plano: diz que irá tecer uma mortalha ao seu sogro, Laertes, e ao término desse trabalho, escolherá um noivo. Penélope, então, trabalha na mortalha durante o dia e a desfaz durante a noite, para que o trabalho nunca tenha fim.

Na obra, Ulisses e Penélope são personagens que representam diferentes faces das mesmas características. Para Calvino:

\footnotetext{
${ }^{67}$ Disponível em $<$ https://jornalggn.com.br/fora-pauta/arthur-bispo-do-rosario-pronto-para-o-juizo-final $>$ Acesso em 15 Jun. 2018.
} 
Do mesmo modo, Penélope também se apresenta como fingidora, com o estratagema do tecido; o bordado de Penélope é um estratagema simétrico ao do cavalo de Tróia e como ele é produto da habilidade manual e da contrafação: as duas principais qualidades de Ulisses são também características de Penélope. (CALVINO, 1993, p.22)

Ulisses costura mares e mapas em busca do seu retorno e Penélope borda e tece a mortalha na espera desse retorno. Entre mares e tecidos, guerras e narrativas, a estrutura mítica que liga a vida militar e o tecer está dada. Esta relação especial entre a experiência militar e os bordados, principalmente no que tange à reelaboração das memórias do tempo de serviço - das guerras e batalhas - por vezes de maneira terapêutica é o foco deste item da pesquisa.

O bordado carrega em si uma relação estreita tanto com a possibilidade de narrar quanto com a questão da memória. Há diversas experiências de grupos que utilizavam o bordado para reconfigurar memórias, tentar superar situações difíceis e empoderar os artistas. Essas práticas dão ao bordado outras dimensões para além da arte decorativa. Quando acionado a fim de contar uma história, o bordado pode ser uma maneira de tornar eventos ou situações traumáticas em força motriz para a produção artística. Esse uso terapêutico do bordado se encontra principalmente em tratamentos baseados na terapia ocupacional ou na arte terapia. Segundo Collier (2011), a partir dos estudos de Francis Reynolds, artes têxteis permitem às mulheres lidar com o luto, a depressão e uma série de deteriorações físicas para expressar, reabilitar e lidar com suas doenças, enquanto simultaneamente experienciam alegria, confiança e laços sociais (COLLIER, 2011, P.104, tradução nossa).

Dentre os casos de grupos militares que utilizaram o bordado como forma de regeneração após a guerra, chama a atenção a história de Ernest Thesiger (1879 - 1961), soldado e artista britânico. Thesiger teve as mãos gravemente feridas durante a Primeira Guerra Mundial e utilizou o bordado como modo de reabilitação dos machucados. Ele então capitaneou a criação do Disabled Soldiers' Embroidery Industry, uma associação que ensinava técnicas de ponto cruz e bordado livre. O objetivo dessa associação era tanto possibilitar uma fonte de renda para aqueles homens que haviam voltado com dificuldades da guerra - tendo em vista que muitos não podiam voltar às suas antigas funções e a pensão dos veteranos era de valor baixo - como possibilitar que esses homens se expressassem artisticamente como forma de superação dos traumas vividos. Segundo Thesiger (1920):

Três anos atrás ao visitar hospitais, eu fiquei impressionado com o interesse que os inválidos demonstravam em bordado e a habilidade que eles demonstravam em trabalhar seus próprios projetos bastante rudimentares. Eu ofereci supri-los com algo um pouco mais decorativo no tocante a desenhos; mas enquanto eles ainda estavam 
no hospital perceberam que não estavam muito interessados em nada além de seus próprios feitos artísticos.

Eu mantive contato com alguns dos artesãos que conheci, e tomei conhecimento de outros que poderiam ser adequados ao meu esquema. Eu lhes expus que se eles trabalhassem os desenhos que eu havia lhes fornecido, seu trabalho seria vendável quando pronto. Uma vez de volta aos homens que ganhavam seu sustento, a questão do valor comercial se afirmava. (THESIGER, 1920, tradução nossa)

Na Austrália, no início do século XX, soldados retornados da Primeira Guerra tiveram produções semelhantes. Durante seu período de reabilitação, eles produziam obras bordadas com temas que variavam entre signos militares, como brasões e armas, e cenas da Europa e de lugares que haviam passado quando estavam lutando na guerra. $\mathrm{O}$ bordado se mostrava um bom modo de passar o tempo para soldados feridos porque podia ser feito de maneira tranquila e lenta, tanto sozinhos em seus quartos quanto em grupo, nas salas comuns. Além disso, eles podiam realizar o trabalho sentados confortavelmente, o que era mais indicado para sua recuperação. Produzir obras têxteis com tantos detalhes e precisão os ajudava a esquecer as experiências da guerra e as sequelas por elas deixadas. De maneira simbólica, o bordado utiliza elementos para contar a história que não representam necessariamente de maneira mimética as personagens da história ou de representação contínua e literal de um fato passado.

Albert Biggs, um soldado e artesão que ficou muito conhecido na Austrália por seu trabalho com bordado, escolhia os motivos de suas obras de arte têxtil muito de acordo com suas experiências pré e durante a guerra. O homem que era um simples trabalhador se tornou um soldado e herói após a guerra. Porém, o tornou também um homem inválido, que já não podia mais exercer suas funções do período da normalidade. O bordado ajudou em sua recuperação em duas instâncias: o corpo, fazendo com que ele retornasse a usar suas habilidades manuais; e a mente, pois através do bordado ele expressava seu trauma. Os bordados de Biggs foram transformados em almofadas por seu sobrinho. Na parte da frente, ficavam imagens da guerra principalmente: brasões, armas e outros signos militares. Na parte de trás, Biggs bordava borboletas. Símbolo cristão e local de ressurreição, a borboleta era uma maneira de expressar que ele próprio estava encontrando uma nova vida após a guerra.

No Brasil, o trabalho da Dra. Nise da Silveira (1905 - 1999), que criou na década de 1940, no Centro Psiquiátrico Nacional Pedro II, um ateliê de terapêutica ocupacional, é uma das principais referências sobre a arte como terapia. Lá, os internos podiam criar livremente a partir de materiais como tintas, telas, argila, etc. As obras produzidas no ateliê, que posteriormente vieram a dar origem ao Museu de Imagens do Inconsciente, não tinham a função 
de ocupar o tempo dos pacientes, mas sim de serem "ponto de partida para associações verbais" (SILVEIRA apud FRANCO, 1992, p.80), possibilitando que aquelas pessoas pudessem se comunicar novamente.

Ao pensar sobre as relações de Bispo do Rosário com o bordado, além da possível referência ao folguedo, talvez o período que passou na marinha também tenha sido importante para a constituição de seu trabalho com os têxteis. Ainda no Brasil, um outro personagem de nossa história tem vivência parecida com a vida militar e o bordado: o marinheiro João Cândido (1880 - 1969), líder da Revolta da Chibata (1910).

Os pontos de entrelace entre as histórias de ambos começam pelo ofício: ambos têm passagens pela Marinha Brasileira. O ofício militar de modo geral está arquetipicamente ligado ao masculino; mas como já foi dito no Capítulo 1, o trabalho com os têxteis é associado de maneira mais frequente ao feminino. Como uma profissão tão diretamente ligada aos homens - e aqui o foco é aprofundado nos homens na Marinha por conta do corpus eleito - poderia ter abrigado tantos exemplos de expressões artísticas usando o bordado como base? Carvalho $(1998)^{68}$ aponta uma possibilidade de explicação dessa proximidade da relação entre o tecer e os trabalhadores da Marinha: João Cândido convivera com a velha Marinha a vela, fora excelente gajeiro, isto é,
encarregado de mastro, um mestre da marinharia. Boa parte do trabalho do gajeiro
tinha a ver com a complicada cordoalha que sustentava e movimenta as velas. Saber
lidar com todas as cordas e cabos, manipulá-los, trançá-los, dar nós de todos os tipos,
João Cândido sem dúvida fazia tudo isso muito bem. Daí a bordar era apenas um
passo. A busca de passatempo para as longas horas de inatividade, sobretudo nos
momentos de calmaria, teria sido o incentivo adicional para o desenvolvimento do
hobby. (CARVALHO, 1998, p. 23)

Bispo do Rosário integra a Marinha em 1925, quando é levado pelo pai para a Escola de Aprendizes de Aracaju, com 15 anos, mesma idade com que João Cândido se tornara integrante, em 1895. Quando ainda no posto de grumete, é encaminhado ao Rio de Janeiro. Diferente de João Cândido, não há registros que Bispo tenha travessia maior do que esta no litoral brasileiro. Marinheiro no período entre guerras, apenas conheceu alguns portos de seu próprio país, ainda que depois, no seu tempo internado "desfiava narrativas de aventuras por países mundo afora" (HIDALGO, 2012). Se Bispo não chegou a pertencer a um tempo de trabalho artesanal essencial na navegação, o tempo embarcado e o pouco contato com outras pessoas além dos companheiros não têm grandes mudanças: o alto-mar era the habitual,

\footnotetext{
${ }^{68}$ As referências a passagens da vida e história de João Cândido apresentadas neste capítulo foram todas retiradas do livro Pontos e Bordados: Escritos da história política, de José Murilo de Carvalho (1998).
} 
ancorando pouco nas cidades. Esse isolamento se somava a reclusões em salas solitárias, como punição por faltas leves que cometia na Marinha. Assim como oscila a mar, também oscilava o comportamento de Bispo entre a disciplina e o desobedecer das regras.

Obedecer a regras claramente não era a principal característica de nenhum dos dois. Se Bispo sofreu represálias nesse sentido, João Cândido foi o líder da Revolta da Chibata quinze anos antes da entrada de Bispo para a vida militar. A Revolta da Chibata, ocorrida em novembro de 1910, foi um movimento de revolta ao tratamento recebido pelos marinheiros na época, que deixou a baía de Guanabara sob ataque de quatro enormes encouraçados. Era um protesto contra as condições de trabalho degradantes às quais os marinheiros brasileiros eram submetidos.

$\mathrm{Na}$ época da Revolta, João Cândido já havia sido rebaixado da posição de cabo por mau comportamento e insubordinação: além das brigas físicas com companheiros, havia proferido uma chibatada contra um grumete. De modo semelhante, Arthur Bispo do Rosário foi demitido quando trabalhava na empresa Light, já num período posterior à sua passagem pela Marinha, por se recusar a cumprir uma ordem e ameaçar o homem que a havia verbalizado. Em 1910, João Cândido era um homem que se impunha pela força física e pela experiência. Era seu corpo forte que lhe garantia o respeito dos demais, não sua posição hierárquica. Hidalgo (2012) descreve que Bispo também era respeitado na colônia dos internos por conta de sua força física, chegando a ganhar o apelido de "xerife":

\begin{abstract}
Bispo era um dos agitados, conforme terminologia local. Chegou aborrecido, agressivo, passou um tempo preso e só então saiu desse exílio de si. Mais livre, passou a se impor com a potência do punho, uma herança da época de marinheiro e pugilista. Pouco a pouco guardas e enfermeiros do Ulisses Viana espicharam o olho para aquele homem parrudo, sisudo, sempre disposto a resolver disputas no corpo a corpo. (...) O xerife praticava o impraticável, o que ia contra as regras da psiquiatria. No dia a dia da insanidade, leis e boas intenções eram diluídas pela realidade bruta. Bispo vislumbrou a brecha e criou um estilo próprio para deter rebeldes. Em vez da luva de boxe, enrolava na mão um pano ou toalha molhada entrelaçada entre os dedos, num improviso de soco-inglês. (HIDALGO, 2012, p.17)
\end{abstract}

Foi justamente nos momentos em que estavam reclusos que ambos os homens realizaram suas obras bordadas. João Cândido produziu seus bordados quando preso na Ilha das Cobras, onde aguardava transferência para o cárcere definitivo, entre novembro de 1910 e abril de 1911. Depois deste período, ele seria transferido para a o Hospital Nacional dos Alienados, na Urca, mesmo hospital onde Bispo do Rosário foi levado em na véspera de Natal de 1938 antes de ser transferido definitivamente para a Colônia Juliano Moreira, em 1939. Foi a primeira vez que Bispo cruzou os portões de um hospital psiquiátrico. 
Foi também numa véspera de Natal que a vida de João Cândido sofreu uma virada. Naquele ano de 1910, os presos da solitária foram deixados numa cela recém-lavada de água e cal. A cela possuía um pequeno espaço para respirar e o comandante responsável havia saído da ilha levando a chave da cela consigo. Os presos sufocaram por efeito dos produtos e, quando a cela foi aberta pela manhã, apenas João Cândido e mais um preso estavam vivos.

A experiência de passar a noite cercado de cadáveres e moribundos teria sido o gatilho para o início de suas produções têxteis. "Devem ter servido como uma espécie de autoterapia instintiva para fugir dos fantasmas que o perseguiam". (CARVALHO, 1998, p. 22). São três as obras de João Cândido que se tem conhecimento, mas apenas duas possuem imagens: Adeus de Marujo e Amor de Marujo. Ambos são realizados em toalhas de rosto - possivelmente o único material disponível na prisão - e linhas pretas e vermelhas.

Figura 48 - Adeus do Marujo, de João Cândido (1910/1911).

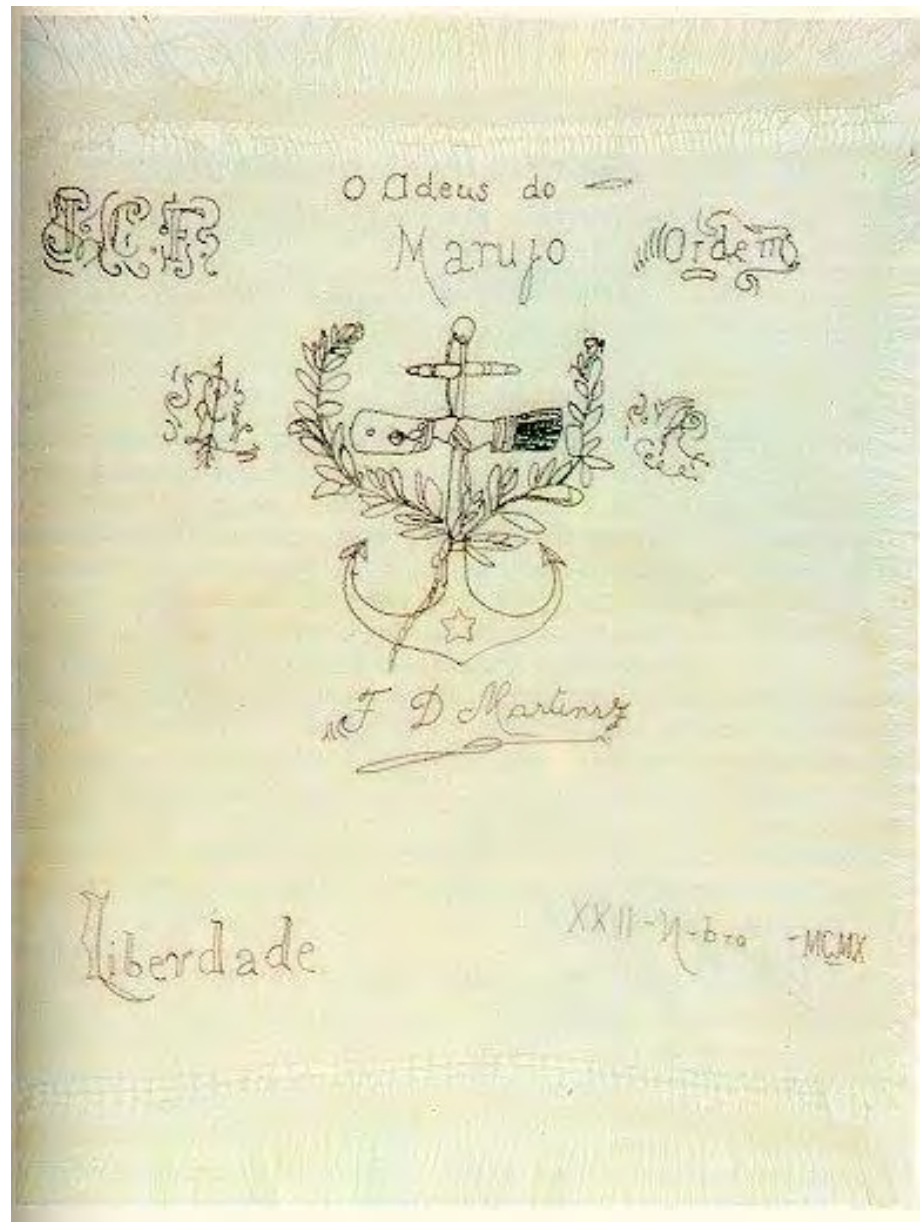

Fonte: Blog Ratos de Arquivos ${ }^{69}$

${ }^{69}$ Disponível em: < http://ratosdearquivos.blogspot.com/2014/02/o-heroi-nacional-e-seus-bordados.html> Acesso em 13 Jun.2018. 
Figura 49 - Amor do Marujo, de João Cândido (1910/1911).

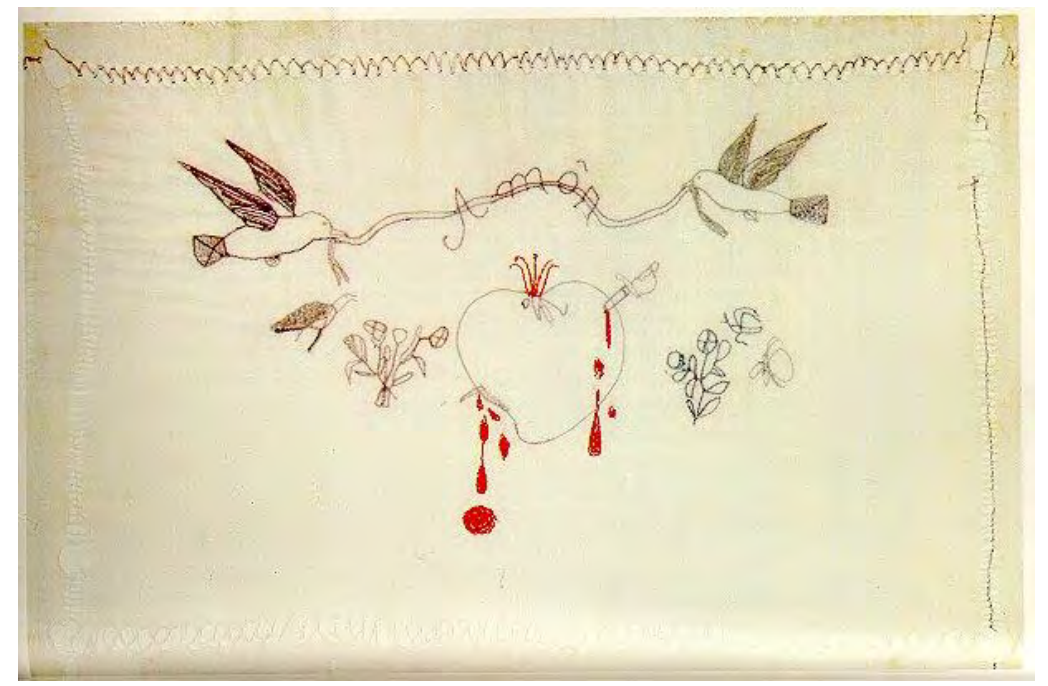

Fonte: Blog Ratos de Arquivos ${ }^{70}$

Se para os funcionários e médicos, o trabalho de Bispo era uma espécie de arte-terapia, para ele era uma expressão de fé. "O traje vulgar, diário, não caía bem na fase sacra. Ele precisava de um traje à altura da devoção e por isso o bordava, onde estivesse, como uma oração" (HIDALGO, 2012). Além disso, o trabalho também parece um sacrifício em nome da sua fé de sua condição de enviado de Deus. Bispo passava por vezes mais de 15 horas à fio bordando. Eram suas obrigações, não um modo de passar o tempo no confinamento. De suas atividades pareciam depender o equilíbrio de sua reorganização do mundo. Diz Hidalgo (2012):

Às prescrições médicas, incluiu-se praxiterapia ${ }^{71}$, ao que Bispo ignorou. Afinal, ele foi o precursor do tratamento no manicômio, menos por terapia, mais por uma fé, ou urgência. Em permanente litígio consigo mesmo, era o mais perfeito tradutor do lema praxis omnia vincit ${ }^{72}$, lido no portão de entrada da Colônia. (HIDALGO, 2012)

Por sua condição santificada, Bispo tinha a obrigação de interceder por aqueles que viviam na Terra e eram merecedores de ficar ao lado de Deus no juízo final. Bispo dizia: "Eu vim para salvar a humanidade, então tenho que ter esses mantos de Cristo, bordados com os nomes de quem vai se salvar quando acabar o mundo". (BISPO DO ROSÁRIO apud HIDALGO, 2012) Ainda que Bispo do Rosário já produzisse obras utilizando o bordado como plataforma, é na Colônia Júlio de Moreira que grande parte de seu trabalho se desenvolve: foram aproximadamente 800 obras. Além do Manto da Apresentação, descrito no item 2.1.1., chamam

\footnotetext{
${ }^{70}$ Ibidem

${ }^{71}$ Tratamento baseado na repetição de um comportamento ou ação. É a aplicação ritual de uma mesma atividade que seria responsável pelo auxílio no tratamento.

${ }^{72}$ praxis omnia vincit, do latim: O trabalho vence tudo (tradução nossa).
} 
a atenção as casacas militares bordadas por ele neste período. Aqui, interessam principalmente não as obras que simplesmente tratam dos símbolos e ícones da marinha, mas sim aquelas que de alguma maneira tomam como referência os trajes militares. São três as obras desta natureza: Lutas (Figura 50), Semblantes (Figura 51) e Uniforme (Figura 52). As obras não têm data precisa definida e estão todas em posse do Museu Bispo do Rosário.

Figura 50 - Lutas (sem data).

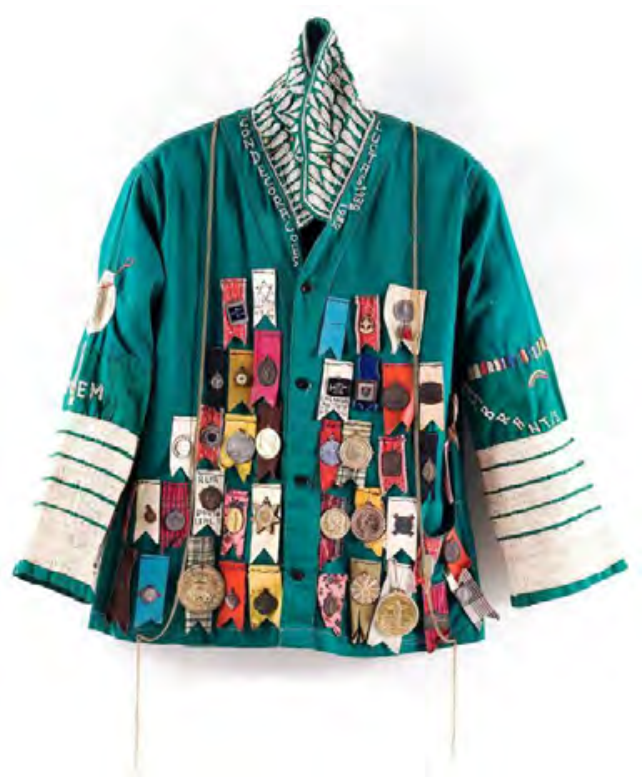

Fonte: Hardecor $^{73}$
Figura 51 - Semblantes (sem data)

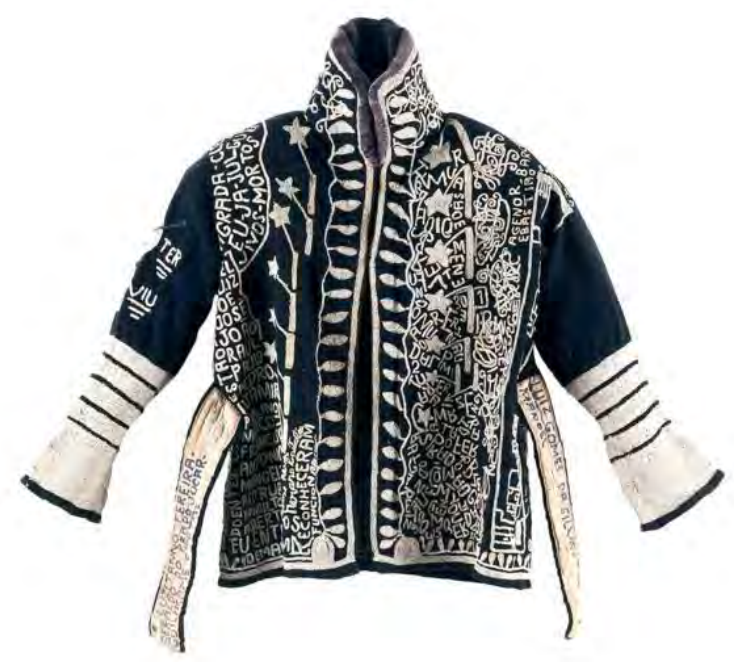

Fonte: Hardecor ${ }^{74}$

Figura 52 - Uniforme (sem data).

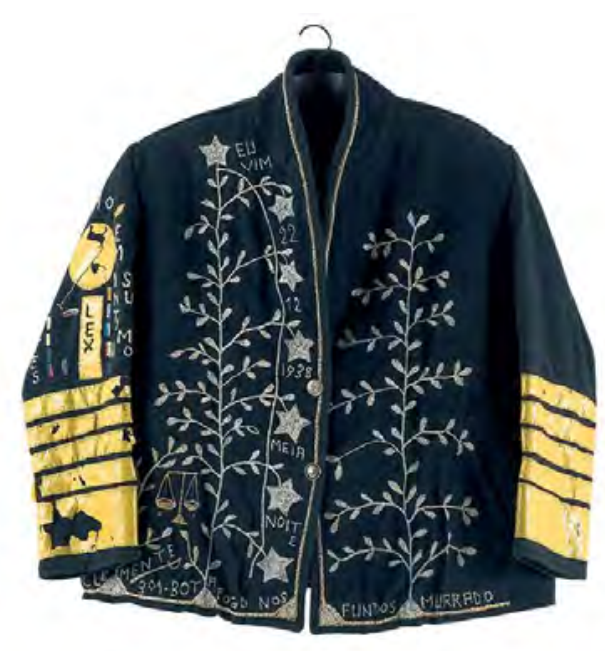

Fonte: Época ${ }^{75}$

\footnotetext{
${ }^{73}$ Disponível em: < https://hardecor.com.br/arthur-bispo-do-rosario/> Acesso em 26 Set.2018.

${ }^{74}$ Idem.

75 Disponível em: <https://epoca.globo.com/vida/noticia/2015/04/loucura-de-arthur-bispo-do-rosario.html> Acesso em 26 Set.2018.
} 
Como muitas das obras de Bispo, os fardões tiveram nome atribuído postumamente (Costa Filho, 2007). A maioria dos nomes parece ter sido atribuído a partir de uma característica principal ou de uma palavra de destaque na obra. A palavra "sembrantes" - uma maneira errônea de escrever a palavra "semblantes", por exemplo, é recorrente nas mangas dos uniformes. Outros elementos são comuns a todas as obras desse segmento, como as faixas amarelas/douradas nas mangas. Estes são detalhes comuns aos uniformes do início do século XX no Brasil, o que reforça a ideia de que Bispo acionava em sua memória detalhes precisos da construção dos trajes militares.

Outra similaridade está no uso das condecorações, como em Lutas. A partir de fitas de cetim e medalhas, Bispo reproduz insígnias militares - está mesmo escrito na gola desta obra a palavra "condecorações". Nesta obra, porém, Bispo realiza uma mudança de paradigma: ao invés de méritos militares, é no campo da religiosidade que se colocam as condecorações do artista. Bispo foi escolhido por Deus para salvar aos homens e, por isso, já não mais importam os títulos de bravura, mas sim sua aliança com o divino e sua intercessão junto a Deus e aos santos.

Nas obras Semblantes e Uniforme, Bispo reproduz a parte frontal de trajes militares, com os botões e os detalhes em torno destes, bastante comum em trajes de gala. Estes detalhes são representados por Bispo por estrelas e folhagens, bordadas em linha branca contra tecido azul. Além disso, na obra Semblantes, Bispo repete a prática de outras obras - inclusive do Manto da Apresentação - de elencar uma série de nomes. O labirinto de letras, segundo as fontes consultadas, representa nomes de companheiros de trabalho nos tempos da Marinha. É uma homenagem ao seu tempo de marinheiro e também um prenúncio do Manto da Apresentação, já que os nomes vêm acompanhados da frase “eu já julgo vivos-mortos”.

Já em Uniforme, fica clara a referência à ruptura com sua vida anterior e posterior à aliança com Deus: na parte da frente há a data "22/12/1938" e as palavras "meia noite" e "Rua São Clemente 301 - Botafogo fundos murado", notadamente o dia da anunciação e sua peregrinação pelas igrejas do Rio de Janeiro - ou o dia em que é diagnosticado como esquizofrênico-paranoide pela primeira vez. Há também uma pequena balança bordada, símbolo que se repete muitas vezes em suas obras e que, possivelmente, significa sua posição divina de intercessor e juiz daqueles que serão ou não admitidos no paraíso na vida eterna. Este símbolo também aparece com destaque no Manto da Apresentação, reforçando a hipótese de seu significado. 


\title{
2.2 O homem de la mancha
}

Há uma informação comumente reproduzida que diz que a segunda obra literária mais lida no mundo após a Bíblia, é o livro Dom Quixote (1605), de Miguel de Cervantes (1547 1616). No entanto, quando se questiona sobre o livro em diversos círculos sociais, parece que poucas pessoas de fato leram a obra. Se a afirmação inicial é verdade ou exagero, não muda o fato de que a personagem Dom Quixote e as passagens de sua história são amplamente conhecidas no Ocidente.

Dom Quixote conta a história de um homem que "do pouco dormir e muito ler se lhe secaram os miolos, de modo que veio a perder o juízo" (Cervantes, 2002, p.59). Alonso Quijano era um homem já velho que, absorto em novelas de cavalaria, começa a enxergar o mundo como se fosse parte das obras que lia. Este homem fidalgo entende que o mundo é um lugar de injustiças e abusos e toma para si a responsabilidade de colocar ordem nesta profusão de erros. Ele adota o nome de Dom Quixote e convence um vizinho, Sancho Pança, a lhe acompanhar em suas aventuras como seu escudeiro. Como todo cavaleiro medieval, Quixote tem uma mulher a quem dedicou sua vida: Dulcinéia del Toboso ${ }^{76}$. Quixote e Sancho Pança passam por diversas aventuras até que, por fim, o cavaleiro, moribundo, recupera sua sanidade e se despede das obras de cavalaria.

Sobre a questão da loucura, no entanto, Vieira (2012) lembra que este é um conceito que se altera conforme o momento:

\begin{abstract}
Ao longo do século XV e até meados do XVII, a loucura ainda estava integrada na vida social e, desde que não muito exagerada, ela continha boa dose de divertimento. A partir daí, no entanto, ela passa a ser excluída da sociedade, e os loucos, ao lado de outros indivíduos considerados diferentes, serão afastados, por meio do internamento, condenando a loucura ao silêncio. (p.21)
\end{abstract}

Assim como no caso de Bispo do Rosário e João Cândido, no entanto, pode ter sido justamente a privação da sociedade o gatilho para a criação artística. Segundo Vieira (2012), alguns pesquisadores afirmam que a obra teria nascido quando Cervantes estava preso. $\mathrm{O}$ escritor esteve encarcerado na Cárcel Real de Sevilla, em 1597; um espaço superlotado, onde toda sorte de criminoso se encontrava. Independente de quando a ideia começa a germinar na mente do escritor, Cervantes escreve Dom Quixote já no fim da vida, por necessidade: aos 58 anos se encontrava em péssima condição financeira. $\mathrm{O}$ primeiro volume foi escrito em $1605 \mathrm{e}$

\footnotetext{
${ }^{76}$ Por vezes, esta personagem aparece associada a Aldonza Lorenzo, outra personagem da obra. Elas, no entanto, não são a mesma personagem. Esta associação parece ser estratégia didática a fim de tornar a adaptação do romance mais fluido.
} 
o segundo, dez anos depois. Cervantes morreria um ano após o lançamento da obra que lhe imortalizou na literatura mundial - no mesmo ano em que morre Willian Shakespeare.

A popularidade da obra fez com que ela fosse muitas vezes adaptada para o cinema, televisão e teatro, além de ter servido de inspiração para diversas outras que tomam Dom Quixote como referência. Dentre as diversas adaptações possíveis, esta pesquisa se debruça sobre o musical $O$ homem de la mancha (1965), com montagem original de Dale Wassermann $(1914-2008)$.

\subsubsection{O primeiro cavaleiro andante}

Em seu livro sobre o espetáculo, o dramaturgo Dale Wasserman conta que os jornais descobriram antes dele sobre $\mathrm{O}$ homem de la mancha. Ele estava na Espanha e tomou contato com uma manchete que dizia que ele estava no país para pesquisas sobre uma peça inspirada em Dom Quixote. Wasserman nunca havia sequer lido o livro, mas decidiu que Madri era o lugar perfeito para tentar. Foi assim que começou sua relação com a obra mais famosa de Miguel de Cervantes.

Não por acaso o espetáculo de Wasserman se inicia com uma inspiração da biografia de Cervantes - em 1597, o escritor foi excomungado pela Igreja Católica e condenado à prisão, onde permaneceu em torno de cinco anos, dado semelhante ao da personagem principal do musical. Mais do que a obra em si, a vida de Cervantes foi de grande inspiração no processo de criação:

\footnotetext{
O que havia atraído meu interesse não era o livro, mas seu autor. Pois se entende que a vida de Miguel de Cervantes foi um catálogo de catástrofe. Que tipo de homem era este - soldado, escritor de peças, ator, coletor de impostos e frequentemente prisioneiro - que podia sofrer infinitas falhas e ainda assim nos seus derradeiros anos produzir o desconcertante testamento que é Dom Quixote? Pegá-lo no pior e final momento de sua carreira, persuadi-lo à auto-revelação, o que poderia implicar algo de significante sobre o espírito humano - ali, talvez, estivesse uma peça que valia ser escrita. (WASSERMAN, 1969, p. 09, tradução nossa, grifo do autor)
}

Segundo Wasserman (1969) o musical O homem de la mancha surge após uma série de tentativas e experiências tomando a obra de Cervantes como ponto de partida. Como o próprio Dom Quixote, havia alguns moinhos a serem vencidos antes do fim. Num primeiro momento, ele escreveu o roteiro de um telefilme que, apesar de toda a estrutura envolvida, não deixou o autor satisfeito, pois "as estruturas da televisão e seu naturalismo assertivo haviam destruído tanto seu design quanto suas intenções” (WASSERMAN, 1969, p. 10). Ele decide, então 
reescrever a proposta pensando num espetáculo para a Broadway. No entanto, o tempo da proposta que lhe fora oferecida se esgotou sem que ele tivesse terminado a reescrita de maneira satisfatória. Wasserman não se incomodou com a adversidade e continuou trabalhando para tentar atingir a forma que aquele conteúdo precisava. Foi quando, segundo ele, recebeu uma ligação do diretor e produtor teatral Albert Marre que lhe sugeriu que transformasse o espetáculo em um musical. Ainda que até então os dois artistas nunca tivessem se conhecido, ele aceitou prontamente sua sugestão.

A peça, porém, não despertou o interesse de produtores de imediato. Dentre os motivos elencados para as negativas vinham características como radical, especial e muito intelectual. O homem de la mancha, por fim, estreou em 22 de novembro de 1965, no ANTA Washington Square Theatre em Nova York, onde ficou em cartaz até $1^{\circ}$ de junho de 1971, após 2329 performances $^{77}$. O espetáculo foi vencedor de cinco prêmios Tony, incluindo o de melhor musical e canção The Impossible Dream se tornou muito popular.

O homem de la mancha não faz uma adaptação do livro para o palco, mas sim, usa elementos do livro misturados a passagens da vida de Cervantes para falar sobre os valores e mensagens da obra. O musical se inicia com Cervantes sendo preso sob uma acusação de heresia, podendo mesmo vir a ser morto. Os outros presos, então, organizam uma espécie de julgamento falso, onde eles vão decidir se o escritor deve ou não ser condenado à morte. Sua defesa vem do manuscrito que carrega consigo: Dom Quixote. Então ele e um servente seu, junto a outros presos, encenam partes da história que é o verdadeiro motivo pelo qual sua vida deve ser preservada: Dom quixote é seu sonho e seu presente a todos.

O personagem de Cervantes é criado em paralelo com o de Dom Quixote. Além da escolha óbvia de que o mesmo ator desse vida aos dois, ambos são sonhadores. O Cervantes no momento mais baixo de sua vida ainda acredita que a arte é capaz de salvar sua vida. O criador e a criatura se fundem diante dos olhos da plateia. Ainda que não seja, portanto, uma adaptação literal, algumas das principais passagens do livro estão no musical: a batalha com os moinhos de vento, a chegada à pensão onde é consagrado cavaleiro e o encontro com Dulcinéia.

Depois de narrar as aventuras de sua personagem, a peça termina com Cervantes sendo chamado para atender ao seu destino. O julgamento real não será visto pela plateia, tampouco seu resultado - ainda que fique a expectativa que o escritor sobreviva. Entre os outros

\footnotetext{
${ }^{77}$ Dados disponíveis em: < http://www.musicalheaven.com/m/man-of-la-mancha/> Acesso em 10 Jun. 2018.
} 
prisioneiros que ficam na cela, fica a impressão de que o sonho e a esperança também os contagiou.

A cenografia e figurinos são assinados por Howard Bay - sendo que os trajes foram cocriados com Patton Campbell. Como vê-se na Figura 53, era relativamente simples, com dois níveis possíveis de ação dos atores, separados por uma escada. A cenografia da montagem original está descrita da seguinte maneira no texto da peça:

A sala comum de uma abóbada de prisão de pedra cujos cantos mais distantes se perdem na penumbra. Possui nichos e recantos onde os prisioneiros fazem seus ninhos. É abaixo do chão, acessada por uma escadaria que pode ser elevada e abaixada, como uma ponte levadiça, e 'iluminada por raios frios escassos filtrados por uma grade acima. Um alçapão no chão pode ser erguido para permitir acesso a um andar ainda mais abaixo. Outros elementos cênicos são colocados e removidos por prisioneiros segundo indicação.

A abobada da prisão é na verdade uma única estrutura básica dentro de cuja arquitetura as cenas de Dom Quixote são concebidas pela atuação de Cervantes. In natura é uma plataforma abstrata cujos elementos são fluidos e adaptáveis. O efeito primeiro é o de improvisação; deve ser, porém, completamente cênico, itens de objetos e figurinos são adaptados de materiais no palco, enriquecidos em efeito pela mala teatral de Cervantes. (WASSERMAN, 1969, p.31, tradução nossa, grifo nosso)

Figura 53 - Cenografia da montagem original de O homem de la Mancha.

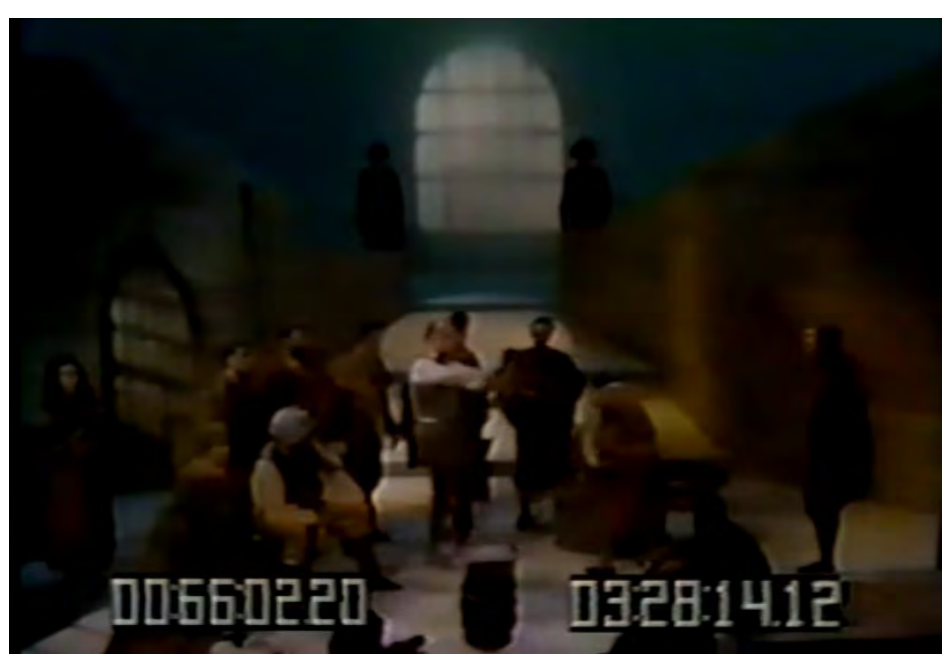

Fonte: Screenshot feito por Maria Celina Gil ${ }^{78}$

Quanto aos figurinos, não há grandes indicações no texto original. Este, indica apenas alguns objetos de cena, principalmente a maleta que Cervantes carrega, onde guarda o manuscrito de sua obra, e elementos que os prisioneiros adicionam a si para modificar seu papel naquele momento. Um exemplo destes usos de objetos se encontra na Figura 54, onde vê-se

\footnotetext{
${ }^{78}$ Vídeo disponível em < https://www.youtube.com/watch?v=yAyOmXeRCDw\&list=PLHvfECAlpnKgbQwB25-Un0VebOkTrYbx> Acesso em 15 Jun.2018.
} 
dois prisioneiros usando máscaras de cavalos. Quando viajando, Dom Quijote e Sancho Pança andam sobre uma estrutura de cadeiras com homens usando cabeças de animais. Ainda na Figura 64, vê-se que quando trajado de Dom Quixote, Cervantes usa uma armadura simples, sem muitos adornos. Ela é formada principalmente pelo peitoral e o capacete, somados a uma lança. A armadura é leve, pois fica claro desde o início da peça que ela é um figurino de Cervantes para sua companhia teatral.

Os trajes dos presos são compostos de cores terrosas, como marrom e ocre, e tentam se aproximar de modelagens do séc. XVI, período contemporâneo a Cervantes. Como se tratam de presos à espera do julgamento em um local precário, no entanto, as roupas são gastas. Muitas vezes, estão trajando farrapos e andrajos. A estes trajes, são agregados elementos de identificação das personagens, como na Figura 55, em que a personagem do Governador está interpretando o dono da pensão e, por isso, adiciona um avental e um lenço a seu figurino. Este avental é comum, feito de um tecido pesado e rústico. É importante que se perceba estes detalhes, pois o tratamento dado a estes adereços na montagem que se analisa a seguir é bastante particular e merece destaque.

\section{Figura 55 - Dom Quixote e o Dono da \\ Pensão/ Governador.}

Figura 54 - Dom Quixote e Sancho Pança.

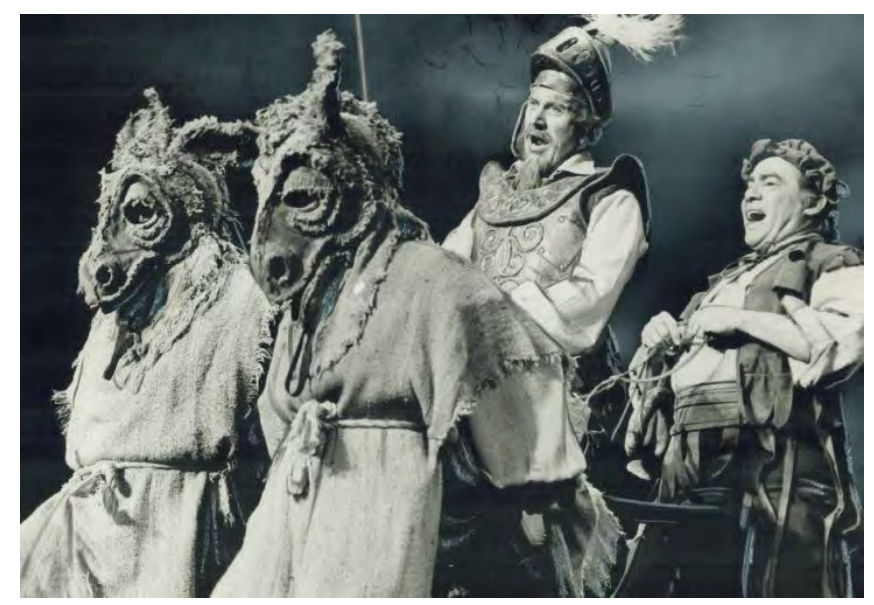

Fonte: The Musical Company ${ }^{79}$

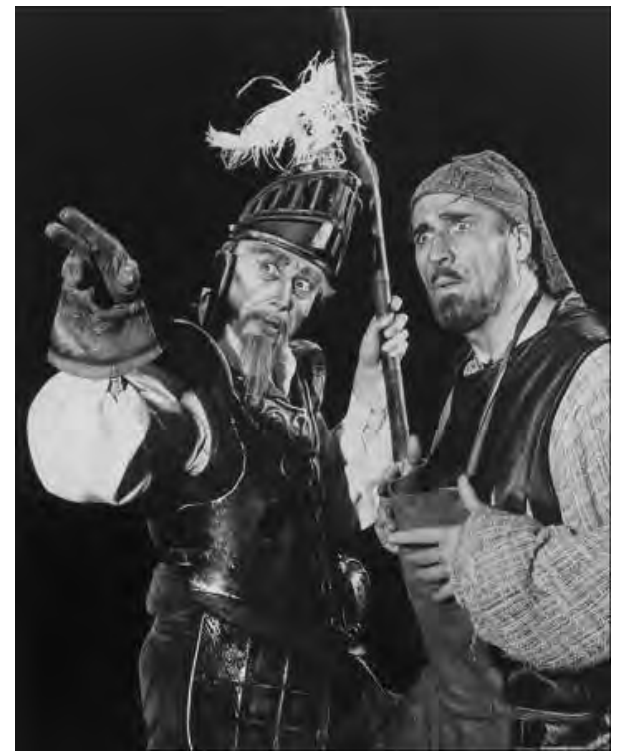

Fonte: Playbill ${ }^{80}$

\footnotetext{
${ }^{79}$ Disponível em <https://themusicalcompany.com/show/man-la-mancha/> Acesso em 13 Jun.2018.

80 Disponível em <http://www.playbill.com/gallery/onward-to-glory-a-photographic-celebration-of-man-of-lamancha-on-its-50th-anniversary-com-372603?slide=2> Acesso em 13 Jun.2018.
} 


\subsubsection{Miguel não Cervantes: Falabella}

O objeto de análise deste tópico é a mais recente adaptação do espetáculo para os palcos brasileiros. O homem de la mancha (2014), dirigido e traduzido por Miguel Falabella, teve duas temporadas: uma em 2014 e outra em $2017^{81}$. O musical já havia sido apresentado no Brasil nos anos 1970, sob a direção de Flávio Rangel e com canções traduzidas por Ruy Guerra em parceria com Chico Buarque. Paulo Pontes também colaborou com a adaptação ${ }^{82}$. Na época, a adaptação da música Um sonho impossível fez muito sucesso, tendo sido gravada pela cantora Maria Betânia.

A adaptação mais contemporânea conta com novas adaptações das canções. Não foi somente, no entanto, no campo das canções que o musical sofreu mudanças. A versão criada por Miguel Falabella tem uma particularidade estética: a visualidade da peça foi baseada na obra de Arthur Bispo do Rosário. Falabella transpôs o enredo do musical para um Brasil fantástico dos anos 1930 e, ao invés de um presídio, ambientou a trama num manicômio. Lá, o personagem de Cervantes (Cleto Baccic) encontra outros internos, que assim como no espetáculo de origem, por ora são acusadores, por ora atores da sua peça.

O Governador (Guilherme Sant'anna), líder dos internos, é uma personagem completamente caracterizada como o próprio Bispo do Rosário. O interessante desta escolha é justamente o papel que Bispo exercia quando interno da Colônia Juliano Moreira. Como citado no item 2.1.2, devido a sua força física e poder diante dos outros presos, Bispo foi apelidado de Xerife pelos funcionários da Colônia. Possivelmente, essa característica de exercer papel de controle sobre os outros internos foi o que norteou a caracterização da personagem no musical.

A cenografia é assinada por Matt Kinley e David Harris, cenógrafos baseados em Londres. Diferente do espetáculo original, esta versão conta com um cenário muito mais grandioso - principalmente na temporada que se toma como base de análise neste trabalho, que por ter sido apresentada em um teatro de maiores dimensões, se constituiu com estruturas mais amplas. Segundo descrição no site da assessoria de imprensa do espetáculo ${ }^{83}$ :

O cenário é uma opressiva estrutura metálica semicircular de oito metros de altura (quase o dobro da altura da última produção que esteve em cartaz no Teatro do Sesi$\mathrm{SP})$, adornado por elementos da arquitetura do início do século 20 , com quatro escadas em curva, interligadas por uma passarela, que conduzem ao nível do palco, o território

\footnotetext{
81 A presente análise se baseia na temporada de 2017.

${ }^{82}$ Informações obtidas em: O Homem de la Mancha. In: ENCICLOPÉDIA Itaú Cultural de Arte e Cultura Brasileiras. São Paulo: Itaú Cultural, 2018. Disponível em:

$<$ http://enciclopedia.itaucultural.org.br/evento398429/o-homem-de-la-mancha>. Acesso em: 12 Jun.2018.

Verbete da Enciclopédia. ISBN: 978-85-7979-060-7

${ }^{83}$ Disponível em < http://www.morenteforte.com/homem-la-mancha/> Acesso em 13 Jun.2018.
} 
dos loucos. É essa estrutura que cria o cenário do manicômio e, ainda assim, remete a um local abaixo do solo, assim como na versão original que é ambientado em um calabouço da inquisição. A estrutura é recoberta por mais de 400 metros quadrados de tule importado pintada a mão pelo artista cênico Vincent Guilmoto, com escrita ao estilo de Bispo do Rosário. Toda execução de construção foi realizada pelo Senai-SP, na escola de Lençóis Paulista. (SITE MORENTE FORTE COMUNICAÇÕES, 26 de agosto de 2014)

As palavras que normalmente se encontram bordadas nas obras de Bispo do Rosário, aqui se encontram nos paineis de tule. Nomes e frases com a caligrafia do artista de ampliam e ganham espaço no palco em diversas cores, já que esta estrutura permitia que em cada momento houvesse uma iluminação diferente incidindo sobre os paineis. Além disso, outros elementos móveis da cenografia também remetem à Bispo do Rosário, como biombos hospitalares com coleções de objetos, numa adaptação das obras do artista, como vê-se na Figura 57.

Figura 56 - Cenografia do espetáculo.

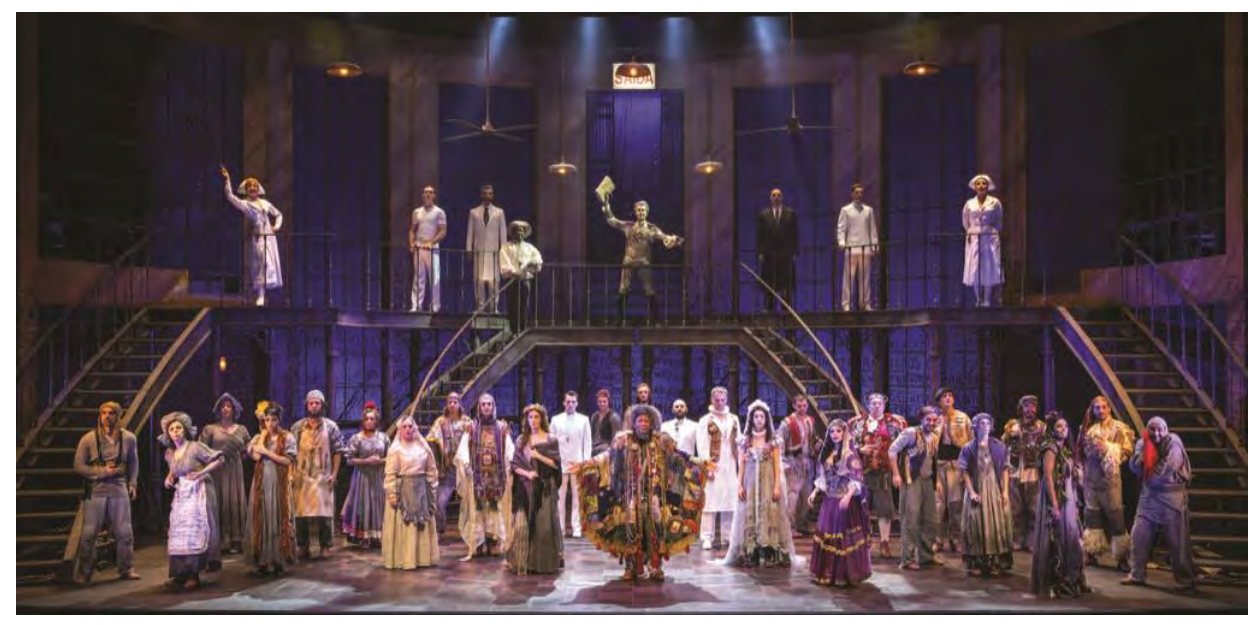

Fonte: Atelier de Cultura. ${ }^{84}$

Figura 57 - Paineis com coleções de objetos.

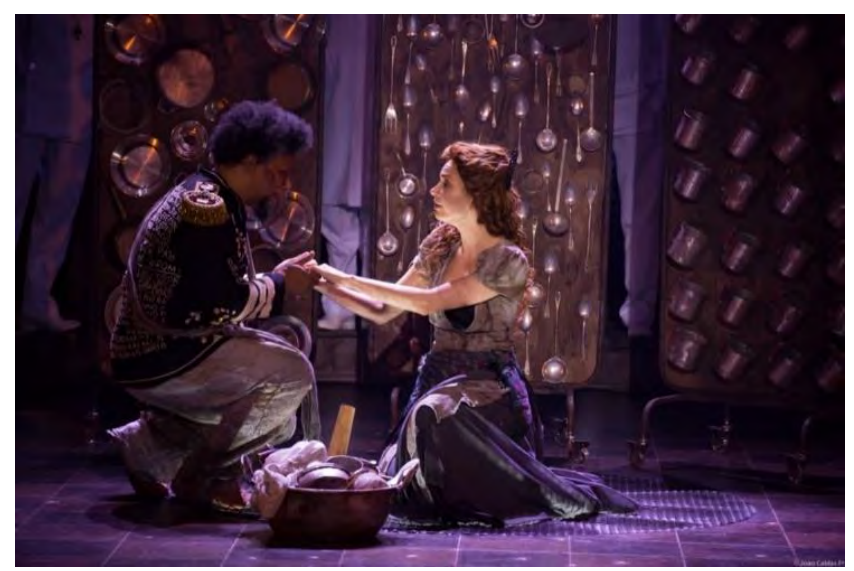

Fonte: Site Atelier de Cultura. ${ }^{85}$

${ }^{84}$ Disponível em < http://www.atelierdecultura.com/en/show/man-of-la-mancha/> Acesso em 15 Jun.2018.

${ }^{85}$ Disponível em < http://www.atelierdecultura.com/en/show/man-of-la-mancha/> Acesso em 15 Jun.2018. 
O espetáculo de proporções enormes conta com 150 figurinos, todos com muito trabalho manual envolvido. Foram mais de dois meses para conseguir deixar tudo pronto e encontrar em diversos lugares a matéria prima para a construção desses trajes. O responsável pelo figurino, o ator e figurinista Claudio Tovar, valorizou o aspecto do artesanal da obra de Bispo do Rosário. Ele ressalta que tudo precisava ser feito à mão, desde os tingimentos até os bordados e apliques de pedrarias. As práticas do acúmulo e da ressignificação dos objetos do cotidiano também estão presentes na concepção de Tovar, que diz que se encantou com a proposta de Falabella principalmente por conta do aspecto do reaproveitamento de materiais típicos da obra de Bispo do Rosário e da dedicação ao trabalho manual:

(...) Bispo do Rosário significa mexer com a reciclagem de materiais, o que é, ainda hoje, uma constante na minha vida. Reciclar, não fazer lixo, reutilizar, é para mim quase uma obrigação. (...) Mas tinha que ser tudo feito à mão, tudo, tudo, como pede qualquer coisa que se relacione com o Bispo do Rosário. Depois, tingimento, envelhecimento, vivência das roupas, ver a coisa tomando forma, a duvida e a certeza misturadas e, aos poucos, começar a sorrir e a relaxar outra vez porque o caminho estava certo. (TOVAR, Box de croquis do espetáculo, sem data)

O espetáculo estabelece uma contraposição entre os trajes do hospício e os trajes da peça apresentada por Cervantes. Os trajes dos internos são mais próximos da concepção do espetáculo original da Broadway. Além de toucas e gorros na cabeça, as personagens usam trajes majoritariamente em tons de cinza, desgastados e sujos, parcialmente rasgados. São trajes simples, sem muitos adornos ou elementos extras, feitos de tecidos mais pesados. Os internos por vezes também carregam alguns objetos como panos ou bichos de pelúcia, talvez como referência a imagens muito comuns do nosso imaginário de pessoas que sofrem de alguma loucura.

Uma das técnicas de bordado aplicadas nos trajes dos internos foi o sashiko. No tópico 1.3.2. já foi mencionada esta técnica, ao analisar os bordados nos trajes de Game of Thrones. A técnica criada para promover o reaproveitamento de tecidos e para consertar peças rasgadas foi usada como detalhe dos trajes dos internos. Na Figura 58 vê-se detalhes da calça da personagem de Cevantes rebordados utilizando essa técnica. Quando assume a personagem do Dom Quixote, Cervantes apenas adiciona o peitoril, os braços e o capacete a seu traje; a calça e camisa são parte de seu traje como interno. Além dele, outras personagens também possuem esse tipo de bordado em lugares específicos das roupas, como se tivessem a necessidade de consertar ao invés de adquirir peças novas. 
Figura 58 - Dom Quixote/Cervantes.

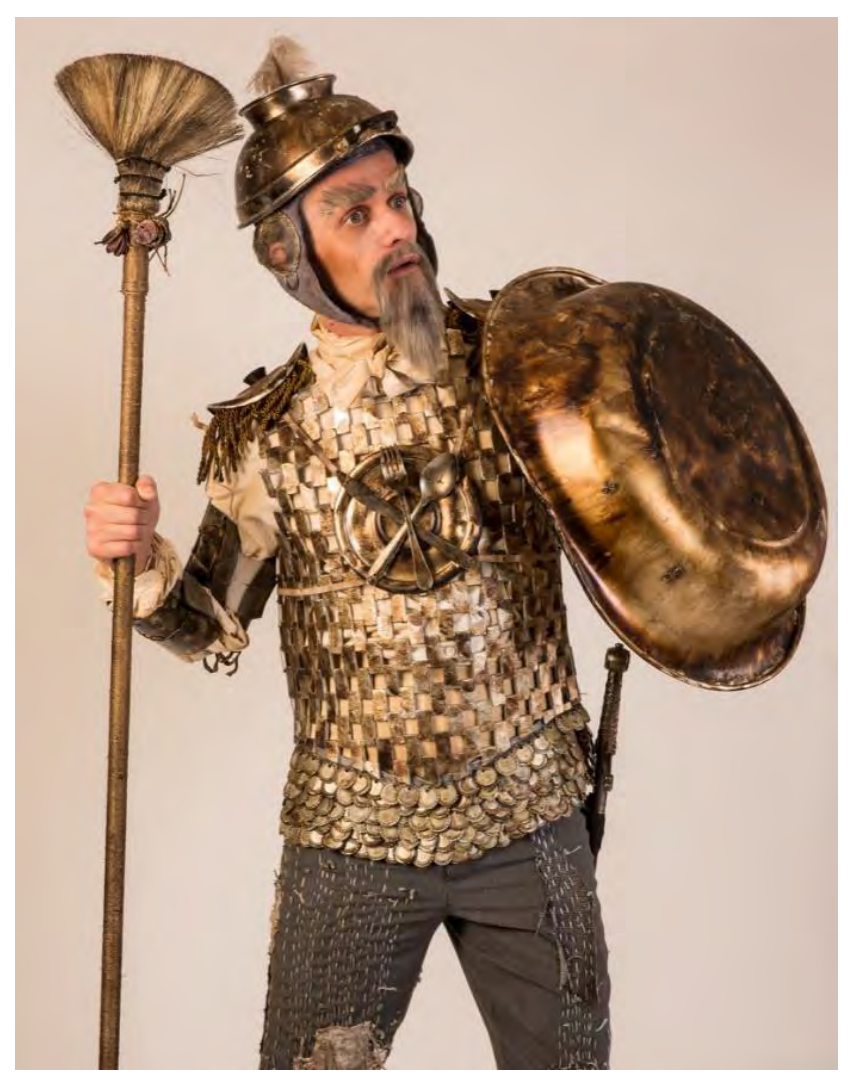

Fonte: Site Atelier de Cultura ${ }^{86}$

Já os trajes dos participantes da peça organizada por Cervantes em sua defesa são mais explicitamente referenciados na obra de Bispo do Rosário. Assim como em Bispo do Rosário, o bordado aparece principalmente em dois grandes aspectos nos trajes de Homem de La Mancha: a escrita e o acúmulo de detalhes. Um dos trajes mais interessantes usando as palavras de maneira plástica é o da mulher do hospedeiro (Figuras 59 e 60). O adereço que usa para indicar sua participação na peça de Cervantes é um avental. Este avental, está bordado com o Menu do dia da hospedaria, além de algumas frases de efeito cômico. Nos parece que, neste caso, o bordado é muito mais importante para o ator no seu processo de criação da personagem do que para efeito de fruição do público. Por ser muito distante dos olhos, o público não consegue ler o que está escrito no avental, mas a atriz consegue. Que tipo de personagem teria um avental com frases mal-educadas ou piadas? Se as palavras estão gramaticalmente incorretas, qual é a educação formal que essa mulher possui?

\footnotetext{
${ }^{86}$ Disponível em < http://www.atelierdecultura.com/en/show/man-of-la-mancha/> Acesso em 15 Jun.2018.
} 
Figura 59 - Croqui da Mulher do Hospedeiro.

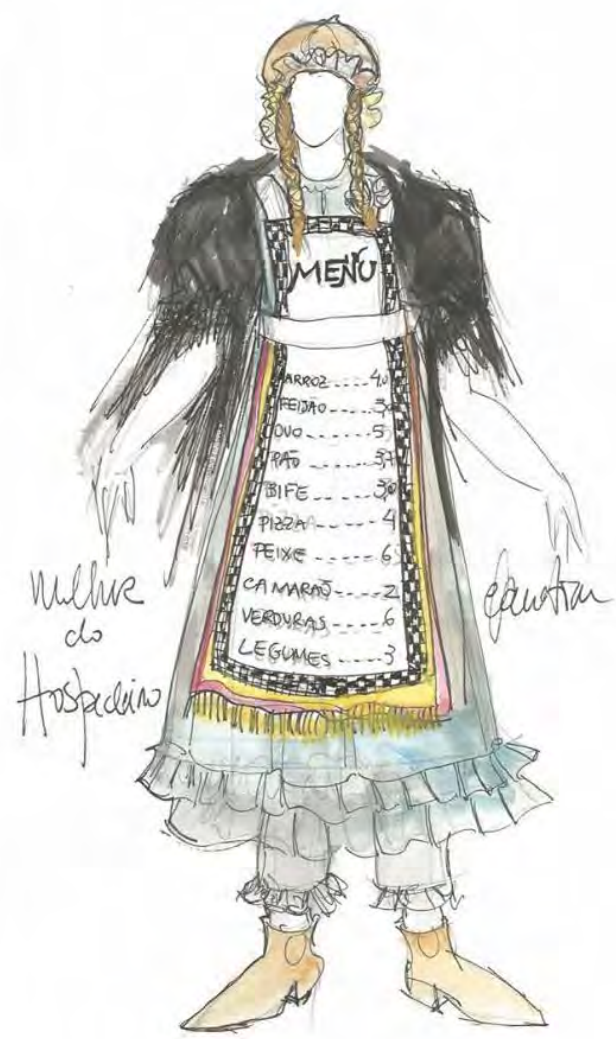

Figura 60 - Detalhe do avental.

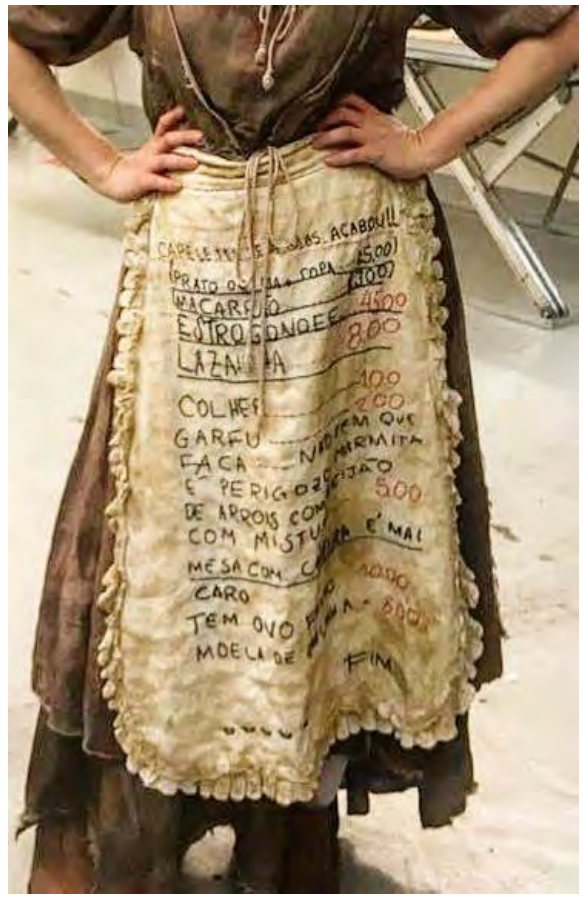

Fonte: Página da atriz Manu Littiéry ${ }^{87}$

Fonte: Acervo da Autora

Quando se vê a comparação entre o croqui planejado por Tovar e a execução final, parece ficar ainda mais evidente que o bordado ali foi uma ferramenta de construção da personagem. No planejamento, todas as palavras estavam escritas de maneira correta e havia apenas o nome e preço das comidas, como num menu convencional. Por fim, o que aconteceu foi que o traje continha outros signos que não planejados. Pode-se pensar que durante a execução esta opção pareceu mais coerente de acordo com a personagem que ia utiliza-lo.

O Duque, que no texto original é descrito como "um homem de elegância porca", aqui é um homem de trajes chamativos e detalhados. Se num primeiro croqui (Figura 61) o Duque usava um longo roupão simples, na execução final (Figura 62) ele ostenta uma roupa cheia de bordados finos, tanto em linhas metálicas quanto com aplicações de pedrarias. Além disso, seguindo a lógica do processo de trabalho de Bispo de Rosário de usar aquilo que tivesse disponível em mãos como matéria prima para a criação artística, a gola do traje do Duque foi feita com gaze hospitalar. Uma vez que se passa dentro de um hospital psiquiátrico, a gaze seria

\footnotetext{
${ }^{87}$ Disponível em: < https://www.facebook.com/manulittierypagina/> Acesso em 10 Out.2018.
} 
um elemento de fácil obtenção para a composição daquele traje. Esta adaptação dos trajes hospitalares também é sentida em outras personagens, como por exemplo o Padre, cuja casula é uma camisa de força solta, criando longas mangas.

Figura 61 - Croqui do Duque

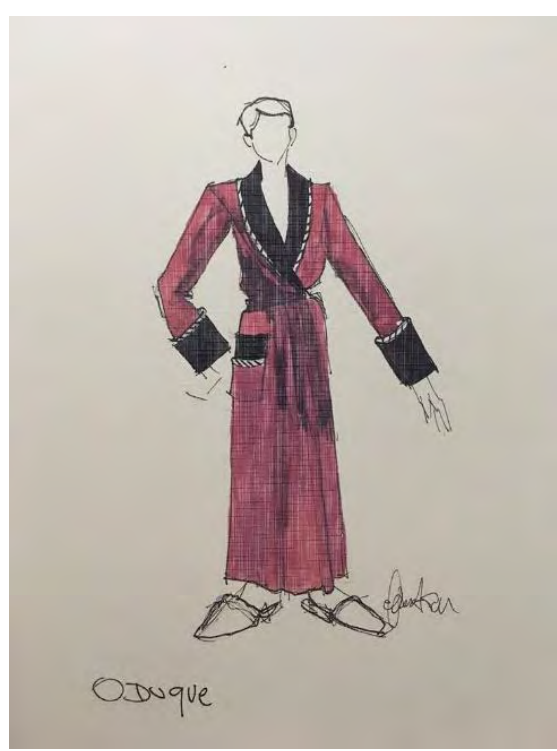

Fonte: Acervo da autora.
Figura 62 - Traje final do Duque

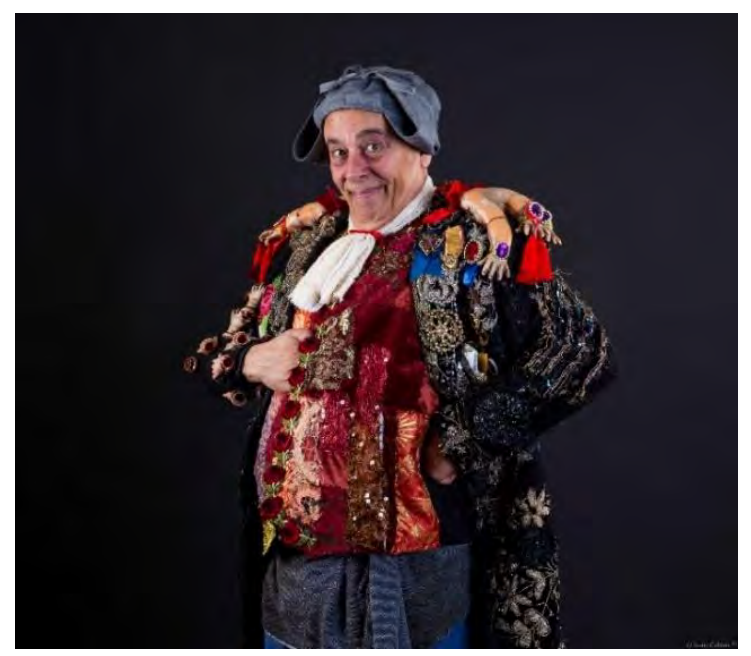

Fonte: Catraca Livre ${ }^{88}$

Por fim, a personagem do Governador, que foi diretamente inspirada em Bispo do Rosário, parece fazer referência direta a algumas obras em seu traje de cena. Colabora para a figura dominante do Governador a voz forte e marcante do ator que interpreta a personagem. Como um verdadeiro chefe - ou xerife - sua figura ocupa todos os espaços quando entra em cena. Seu primeiro traje usado no espetáculo é inspirado no Manto da Apresentação (Figura $63)$.

Uma das primeiras diferenças óbvias entre a obra de Bispo e o traje de cena que ela inspirou é a cor: o manto criado por Tovar é majoritariamente azul, não vermelho. Ainda que o azul seja a cor mais comumente associada ao campo semântico da marinha, a obra de Bispo parece se referenciar mais fortemente nos folguedos que representam navegações, e estes parecem ser mais abundantes com a cor vermelha. Outros elementos, porém, foram reproduzidos de maneira bastante semelhante à obra original. As dragonas nos ombros e as cordas que cruzam o corpo são exemplos desta fidelidade. Há também franjas douradas e outros detalhes do gênero nas bordas do tecido.

\footnotetext{
${ }^{88}$ Disponível em: <https://catracalivre.com.br/sp/agenda/gratis/miguel-falabella-dirige-o-homem-de-la-mancha-
} novo-musical-gratuito/> Acesso em 20 Jun.2018. 
A maioria dos bordados no manto são de desenhos maiores, diferente da obra de Bispo. Do lado direito há uma grande lua e estrelas e ao longo do traje há detalhes que misturam bordados e rendas. Talvez para conferir ainda mais volume, partes do manto sejam feitos com retalhos de diferentes estampas e texturas, que formam diversas seções diferentes. Em diversos locais, há construções com diversas técnicas têxteis que reproduzem pequenos oratórios, com imagens de santos e orações que lhes são dedicadas. Possivelmente o aspecto mítico-religioso do Manto da Apresentação esteja presente neste traje através dos múltiplos pedidos de proteção aos mais diversos santos.

Há também referências a outras obras de Bispo, como as bandeirolas feitas de fita de cetim - do mesmo modo que na obra Lutas. Junto a elas há medalhas religiosas e botões, simulando condecorações. Diferente do Manto da Apresentação, porém, o traje não conta com inscrições na sua paerte interna. Ele é forrado por um tecido roxo liso e não contém bordado algum à vista. Independente disto, o trabalho é primoroso e cheio de detalhes. A artesania era essencial para que os trajes tivessem não só a aparência como também o processo semelhante ao de Bispo.

Figura 63 - Guilherme Sant'anna com o primeiro traje usado no espetáculo.

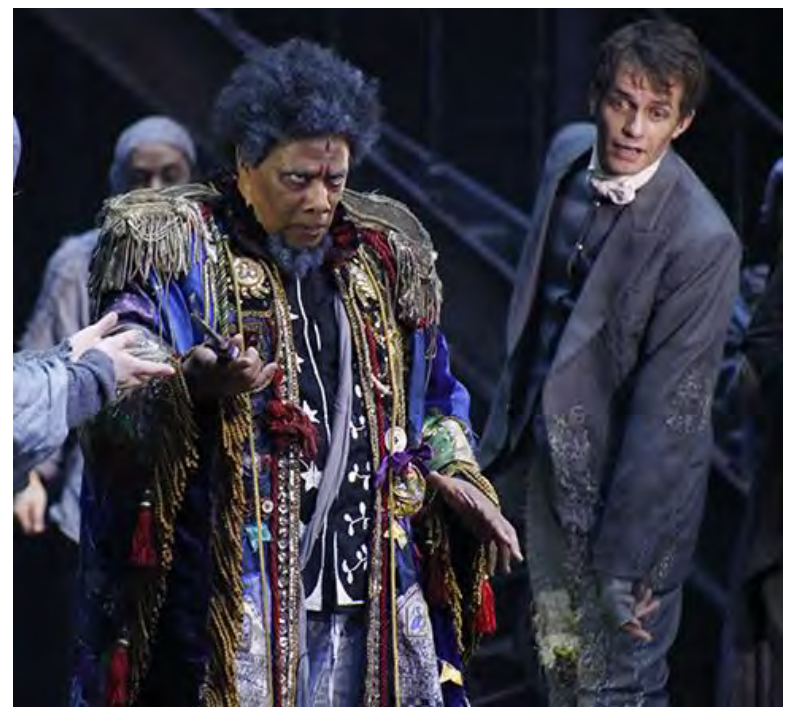

Fonte: Fiesp ${ }^{89}$
Figura 64 - Detalhe do traje do

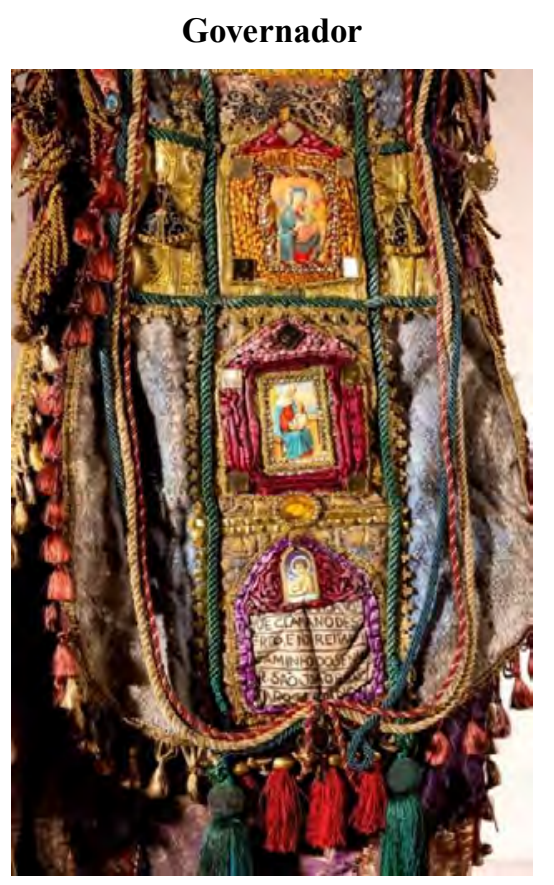

Fonte: Atelier de Cultura ${ }^{90}$

89 Disponível em: <http://www.fiesp.com.br/noticias/miguel-falabella-faz-referencia-a-bispo-do-rosario-emhomem-de-la-mancha-espetaculo-estreia-dia-1309-no-teatro-sesi-sp/attachment/bm500x343_mg_6106/> Acesso em 28 Set.2018.

90 Disponível em: <http://www.atelierdecultura.com/wp-content/uploads/2014/09/Man-Of-La-Mancha-04.jpg> Acesso em 28 Set.2018. 
Por baixo do manto, há outro traje inspirado por uma obra de Bispo, Semblantes: um paletó com referências a uniformes da marinha que conta com diversos nomes bordados por toda a parte de trás (Figura 65). Na versão para $\mathrm{O}$ Homem de La Mancha, a equipe de figurino bordou os nomes das pessoas que trabalharam na peça, como forma de homenageá-los. Assim como Bispo homenageara seus companheiros de trabalho da Marinha em sua obra e lhes garante sua salvação, a equipe de figurino homenageia seus companheiros e os coloca no centro do palco do teatro.

Figura 65 - Traje inspirado na obra Semblantes.

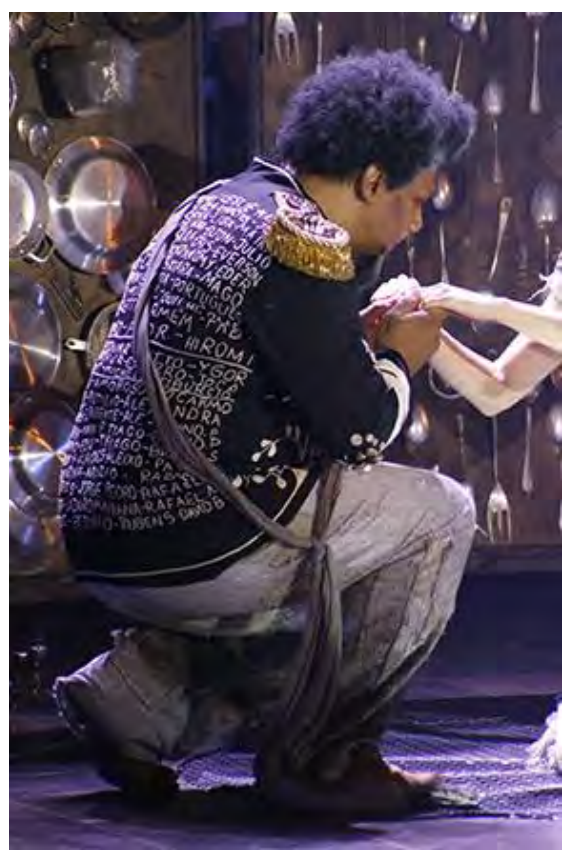

\section{Figura 66 - Guilherme Sant'anna caracterizado} como Bispo/Governador.

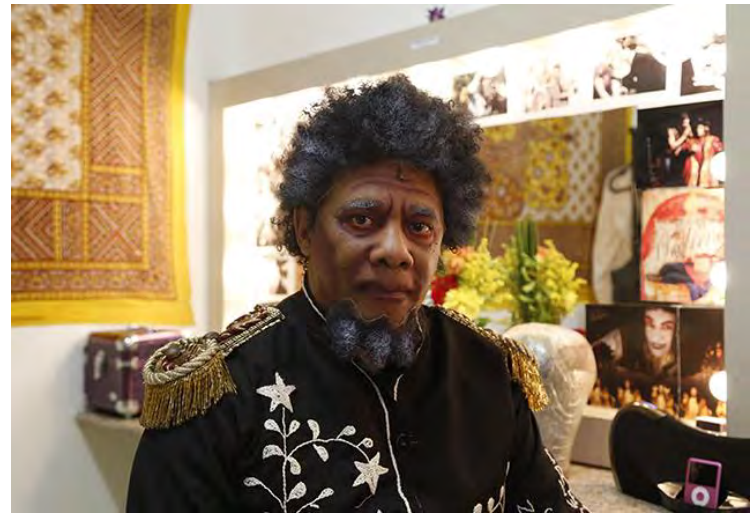

Fonte: Fiesp $^{92}$

Fonte: Fiesp ${ }^{91}$

Além de dialogar com a visualidade de Arthur Bispo do Rosário, O Homem de La Mancha se dedicou a um trabalho artesanal que traz muitas novas gamas de significado aos trajes. O tempo que a equipe se dedica à criação dos trajes e as múltiplas referências pessoais dos profissionais envolvidos aparecem em cena na beleza do trabalho artesanal. Principalmente por fazer uso de uma técnica ancestral como o bordado, há uma tradição envolvida na feitura dos trajes e uma relação de proximidade com os materiais. A escolha dos tecidos e dos símbolos bordados não é gratuita e tem mais do que uma função decorativa: o bordado neste espetáculo conta suas próprias histórias com Bispo, com a equipe e com os atores.

91 Disponível em: <http://www.fiesp.com.br/noticias/em-noite-de-pre-estreia-homem-de-la-mancha-temapresentacao-exclusiva-para-convidados/> Acesso em 28.set.2018.

${ }^{92}$ Disponível em: <http://www.fiesp.com.br/noticias/guilherme-santanna-e-a-lucidez-de-ser-o-governador-em-ohomem-de-la-mancha/> Acesso em 20 Set.2018. 


\subsection{Gabriel Villela}

Antônio Gabriel Santana Villela nasceu em Carmo do Rio Claro, Minas Gerais em $1958^{93}$. Formado pela Escola de Comunicação e Artes da Universidade de São Paulo, Villela se torna um dos diretores mais aclamados dos anos 1990 no Brasil. Sua obra é frequentemente referida como dotada de traços do barroco, do circo-teatro, dos folguedos e do teatro popular, mambembe principalmente por conta das narrativas visuais que constrói. Nesses tipos de espetáculo teatral, o improviso e a grande variedade de técnicas para compor um traje costumam encontraram espaço. $\mathrm{Na}$ obra de Villela, qualquer material tem potencial simbólico, independente se sua origem ou composição. O reaproveitamento de materiais, sua transformação e ressignificação também aproximam os trajes criados por ele do circo-teatro. $\mathrm{O}$ teatro e o circo dividem, sobretudo, um caráter artesanal, manufaturado, que se encontra em Gabriel Villela também pelo modo como usa dos têxteis e do bordado.

Apesar de ter encenado seu primeiro espetáculo Você vai ver o que você vai ver em 1989, é em 1992 que sua estética alça voos mais altos com a montagem de Romeu e Julieta do Grupo Galpão (Figura 67). O sucesso de crítica e público foi também muito definidor para a construção de uma visualidade característica do encenador e de uma configuração de seu modo de trabalho e processo criativo.

Figura 67 - Romeu e Julieta do Grupo Galpão.

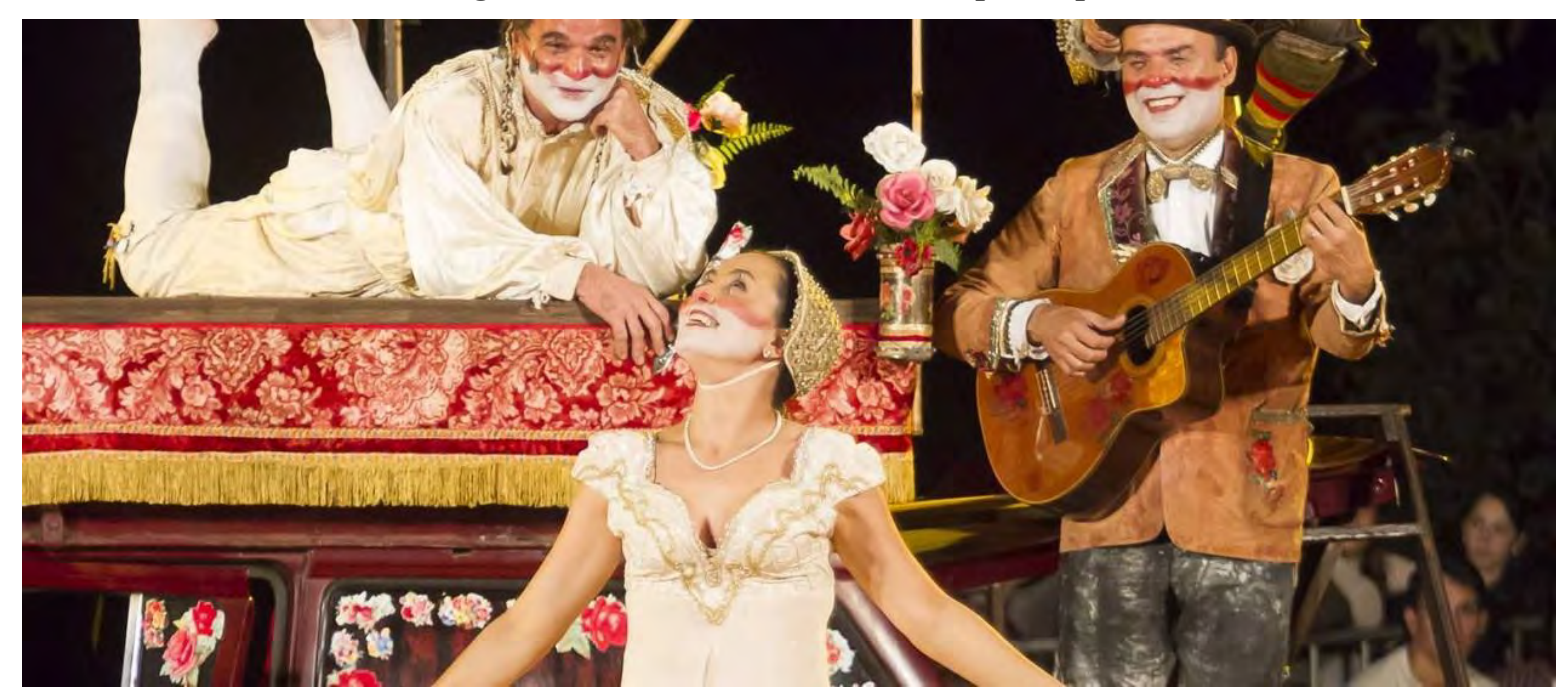

Fonte: O Globo ${ }^{94}$

\footnotetext{
${ }^{93}$ As informações acerca da bibliografia do encenador se encontram no verbete homônimo da Enciclopédia Itaú de Teatro. Disponível em: <http://enciclopedia.itaucultural.org.br/pessoa359371/gabriel-villela> Acesso em 30 Set.2018.

94 Disponível em: <https://oglobo.globo.com/cultura/galpao-celebra-seus-30-anos-com-peca-romeu-julieta6529912> Acesso em 30 Set.2018.
} 
O método de trabalho de Gabriel Villela como diretor é muito particular. Ele inicia o trabalho pela concepção do figurino e da cenografia. Suas roupas estão sempre carregadas de significados e arquétipos e o figurino tem uma dramaturgia própria. Em entrevista em vídeo a Braga (2013), Villela diz que

\footnotetext{
“(...) não é cenário e figurino somente. É concepção, e ela envolve todos os gêneros artísticos. Por mais que você tenha que traduzir em nomenclatura - que ora se chama cenografia, ora figurino -, na verdade é só uma parte estrutural das artes cênicas, que prevê como resultado o homem, a palavra e o ator".
}

Assim, produzindo em seu ateliê junto com outros criadores e colaboradores, ele tem tempo para elaborar e estudar materiais e construir sua estética. Realizando esse trabalho com calma e antecedência, o diretor dá aos atores a oportunidade de ensaiar e obter vivência com os tecidos e elementos do cenário, estimulando assim seu trabalho. A palavra-chave aqui é tempo. Talvez por conta desta relação tão particular com o tempo que a artesania esteja tão fortemente ligada a seu trabalho.

Seu ateliê é itinerante. Quando realiza produções fora de Minas Gerais, Gabriel Villela monta seu ateliê no local em que a peça está sendo ensaiada para que possa trabalhar com os têxteis e texturas durante a produção. $\mathrm{O}$ trabalho no ateliê começa antes da chegada dos atores. Além disso, os trajes são montados sobre o corpo do ator, invertendo assim o movimento mais comum do vestir: não é o ator quem tem que se adaptar a roupa, mas sim a roupa que se adapta e conversa com o corpo de quem a usa, pois é nessa troca que o personagem nasce.

O bordado é um elemento constante e de muita importância em seus trajes. Com ele, Villela guarda relações profundas que permeiam desde sua origem mineira, até sua tradição familiar e as figuras artísticas que mais the inspiram esteticamente. Um dos artistas em quem Villela se inspira, tanto na visualidade quanto nos processos de criação, é Arthur Bispo do Rosário.

Neste subitem, será realizada uma breve análise alguns trajes segundo o seguinte critério: trajes de espetáculos em que o profissional responsável pelo bordado foi creditado na equipe. Esta decisão se baseia na ideia de que havia um trabalho diferenciado do bordado nestes espetáculos, que ultrapassava uma opção decorativa. Os espetáculos são $\mathrm{O}$ soldadinho e a bailarina” (2010), “Os Gigantes da Montanha” (2013), Mania de Explicação” (2014) e A Tempestade (2015). Em todos estes espetáculos, a responsável pelos bordados foi Giovanna Villela, irmã do encenador. 


\subsubsection{Bispo e Villela se encontram}

Em diversas entrevistas, Gabriel Villela cita duas figuras que foram essenciais para a criação de sua linguagem pessoal: Arthur Bispo do Rosário e Sinhá Olympia. Sinhá Olympia (1889 - 1976) foi uma figura muito conhecida de Ouro Preto, principalmente entre as décadas de 1950 e 1970. Ela andava pelas ruas da cidade usando roupas coloridas, chapéus, enfeites de flores e papéis de balas e bombons, bijuterias e um cajado, também adornado com linhas, fitas e papéis. Além disso, era uma mulher de personalidade forte e uma grande contadora de histórias ${ }^{95}$.

Olympia nasceu em Santa Rita Durão, distrito de Mariana, em 31 de agosto de 1889. A história de como se desenvolveu sua loucura é pouco certa, apesar de todas as versões conhecidas relacionarem seu estado a uma frustração amorosa. O que se sabe é que foi por volta dos 29 anos que saiu da casa da família e passou a viver sozinha e andando pelas ruas em Ouro Preto. A versão mais mística de como tudo teria se dado conta que seu pai proibira seu casamento com o rapaz por quem estava apaixonada, pois ele era pobre. Sinhá Olympia vinha de uma família de posses e fora educada em bons colégios. Chegou a ser professora e era considerada por todos uma mulher muito bonita. Dizem que depois que seu pai não deixou que ela casasse com o homem que escolheu, sua potencial sogra lhe enviou abacates enfeitiçados e depois de comê-los, Olympia nunca mais foi a mesma.

Ela era conhecida pelo acúmulo de materiais em seus trajes - característica que partilha com Bispo do Rosário. O acúmulo, no entanto, não significa a simples sobreposição de elementos sem lógica. Assim como Bispo, Sinhá Olympia colecionava objetos dentro de uma lógica interna definida e os ressignificava como partes de trajes e adereços, lhes dando uma nova vida. Gabriel Villela se inspira nessa imagem para compor seus trajes em muitos espetáculos. O traje criado para Luana Piovani no espetáculo Mania de Explicação (2014) é um exemplo de ressignificação de materiais aliada aos bordados (Figura 68).

O traje de Mania de Explicação coloca no bordado a função de ao mesmo tempo gerar uma textura interessante e de trabalhar com o lúdico que envolve toda a história da peça. A história se centra na história de Isabel, uma menina de 13 anos descobrindo o mundo e tentando dar nome às confusões de sua mente recém-adolescente. $\mathrm{O}$ corpete da personagem de Luana Piovani mistura diversas técnicas de bordado, contando com pedrarias, aplicações, além de fuxicos e correntes (Figura 68). Estes elementos de diferentes naturezas sobrepostos fazem com

\footnotetext{
${ }^{95}$ Disponível em: <https://tccolympia.wordpress.com/> Acesso em 30 Set.2018.
} 
que o traje adquira um volume maior e interaja com a iluminação, ao refletir o brilho da luz nas correntes e pingentes aplicados. O acúmulo de materiais não é feito de forma gratuita. Suas cores e tecidos são pensados cuidadosamente.

Além disso, Villela utiliza o bordado de maneira muito semelhante a do Bispo do Rosário ao criar insígnias e condecorações bordadas para o traje do Guarda-chuva (Luiz Araújo). Assim como nos fardões de Bispo, há medalhas e identificações presentes no colete da personagem, possivelmente também fazendo referência aos trajes militares. Porém, diferente de Bispo, em Mania de Explicação há uma preferência por misturar bordados e pedrarias ao invés de aplicar também referências religiosas como medalhas.

Figura 68 - Luana Piovani em Mania de

\section{Explicação (2014)}

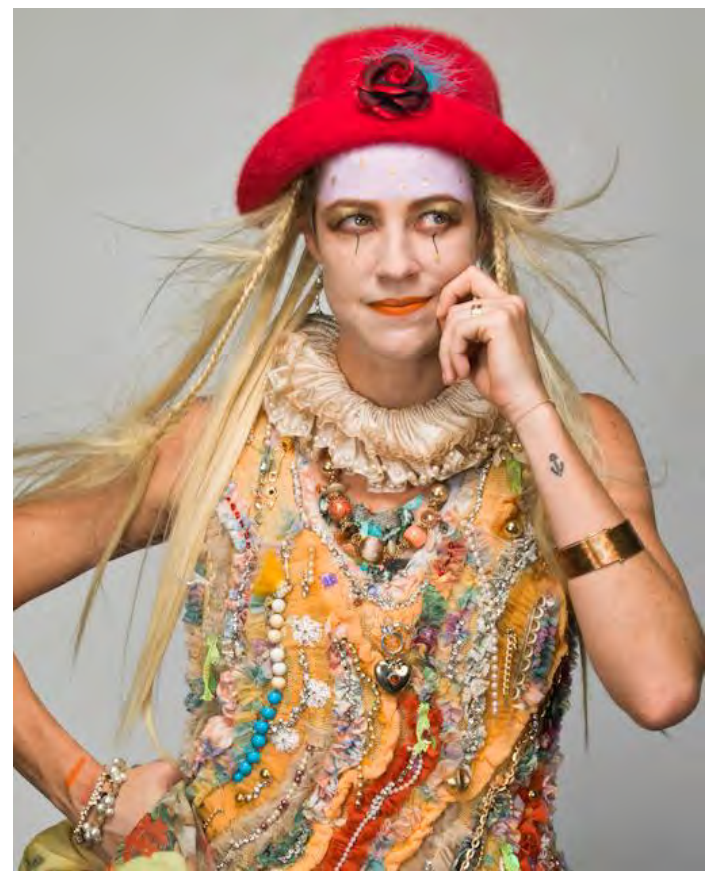

Fonte: Arteview $^{96}$
Figura 69 - Luiz Araújo em Mania de Explicação (2014)

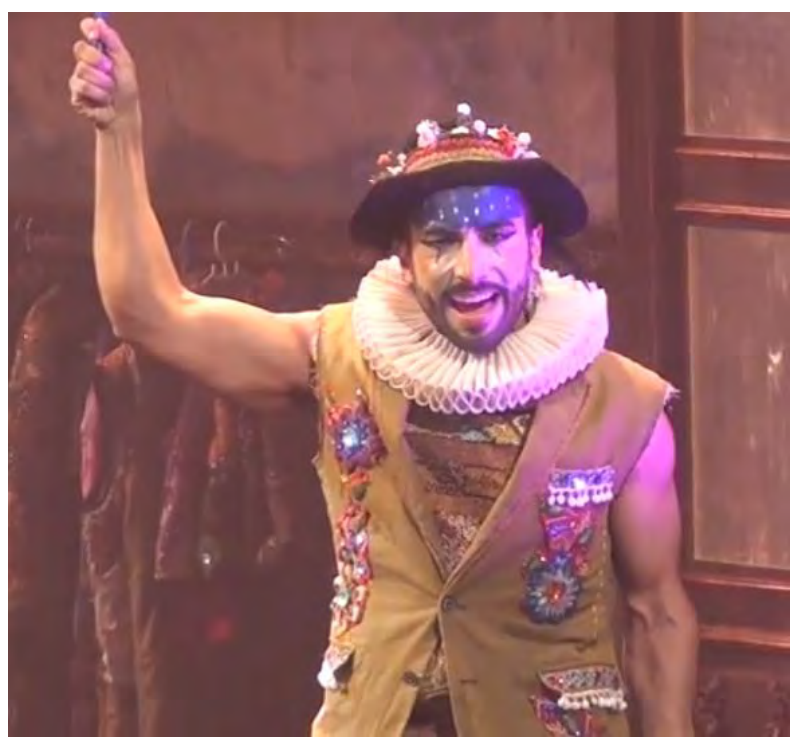

Fonte: Frame do Youtube ${ }^{97}$

O processo de ressignificar e dar importância àquilo que para os outros parece sem valor aparece em Villela através do bordado. Assim como outras técnicas do cotidiano, o bordado foi sendo deixado de lado ao longo do tempo, por muitos motivos. Na contramão desta prática, Villela traz o bordado para o protagonismo em suas obras e explora seus potenciais criativos e artísticos. Para ele, “a descontextualização de um objeto vulgar e a recontextualização deste

${ }^{96}$ Disponível em: <https://arteview.com.br/musical-infantil-mania-de-explicacao-com-luana-piovani/> Acesso em 30 Set.2018.

${ }^{97}$ Disponível em: <https://www.youtube.com/watch?v=hBthpI6rhaE> Acesso em 01 Out.2018. 
objeto, dando a ele um valor nobre" (Villela apud Muniz, 2004, p. 188) é fundamental na cultura popular.

Com Bispo do Rosário, Villela também compartilha duas fortes influências: os folguedos e a religiosidade de seus locais de origem. A religiosidade, este elemento fundamental da obra de Villela é também um dos principais traços do artesanato de Minas Gerais. As imagens religiosas, que têm Aleijadinho como principal referência, trabalhadas em madeira e cerâmica são muito populares. Além de imagens, os ceramistas também produzem objetos do cotidiano e de decoração. A pedra-sabão também é muito utilizada no artesanato de Minas.

A identificação de Villela como encenador barroco também se liga à religiosidade. Segundo Viana e Muniz (2017):

Há sim o resgate de elementos da memória mineira, das festividades de rua, das procissões e celebrações católicas. Inspirações vêm dos trajes cotidianos de personagens míticas ou folclóricas de Minas. Aleijadinho é trazido à tona, com um barroco que é genial justamente por sua simplicidade, quando comparado ao barroco produzido nas cortes imperiais europeias (...).

Villela cria a partir de um barroco rebuscado, expressivo, dramático. E, para desespero dos que desejam categorizar sua obra, é um barroco menos brasileiro e mais da América espanhola, em que as estátuas não choram só sangue, como as nossas: choram rubis e topázios. (VIANA e MUNIZ, 2017, p.287)

A religiosidade de Villela é melodramática ao mesmo tempo que popular. Captura elementos dos festejos religiosos populares e dos santos de imagem forte nas igrejas, buscando de cada um o que melhor se identifica com as histórias que quer contar. Segundo Villela (2011), seu professor lhe fez a seguinte observação acerca de sua estética:

Há três coisas aí que sustentam o teu trabalho: a arte popular, de rua; o caráter religioso, com as procissões, festas populares, envolvendo também a arte do reisado; e o circo-teatro, que era o único teatro que mesmo a nossa geração de cinquenta anos só tinha visto em Minas Gerais na infância, quando vinha da roça para a cidade e o circo se instalava na chácara do meu avô. (VILLELA apud VIANA, MUNIZ e PEREIRA, 2011, p.77-78)

O reisado identificado na fala de Villela como uma característica definidora de sua estética é uma festa popular que ocorre no período de Natal, entre 24 de dezembro e 6 de janeiro (Dia de Reis) e é dedicada aos Reis Magos da narrativa do nascimento de Jesus Cristo. Ainda que haja mudanças no folguedo conforme o local em que ocorrem, a estrutura se mantém. Há um mestre, responsável pelo canto e por coordenar o grupo; um contramestre, que recolhe os donativos; instrumentistas e cantores; três representantes dos reis magos; e por vezes, um 
embaixador, que pede para entrar nas casas da população no caminho. Eles também contam profecias e lembram passagens sobre o nascimento de Jesus ${ }^{98}$.

É evidente, portanto, que o trabalho de Villela chama a atenção principalmente pela aliança que ele guarda com uma espécie de brasilidade. Porém, se num primeiro momento, essa brasilidade parecia se restringir a uma herança mineira, com o passar do tempo seu trabalho passou a abarcar outros elementos que compusessem a brasilidade que Villela procurava. Informações, têxteis e técnicas vindas de outras etnias, de povos originários da região da Amazônia, de Parintins e do Nordeste - local de onde vem a formação de Shicó do Mamulengo, seu parceiro na criação de adereços de diversas peças. Atualmente, entendendo que o brasileiro é macunaímico e sincretizado por excelência (Villela apud Muniz, 2004, p.190), ele introduziu elementos de outros países. No bordado isso se mostrou particularmente frutífero, pois elementos e obras têxteis de lugares como Peru, Leste Europeu, Birmânia, etc. tem sido usados para compor essa estética do acúmulo e da mistura tão característica da cultura popular.

No espetáculo $O$ soldadinho e a bailarina (2010) este sincretismo de culturas se expressa com força através dos usos do bordado. Os trajes do espetáculo, que conta a conhecida e trágica história do soldadinho de chumbo perneta que se apaixona pela boneca bailarina, misturam peças trazidas de fora do país com aplicações de bordados e pedrarias no ateliê de Villela em Minas Gerais (Figuras 70 e 71). Pereira (2011) aponta que um pouco antes do processo de produção do espetáculo, Villela tinha uma viagem marcada para o leste europeu. Encontrou em Budapeste um comerciante que possuía lotes de tecidos e trajes antigos e os adquiriu para compor os trajes da nova produção.

Segundo o diretor, eram peças de um festival equestre das décadas de 1920 e 1930 ,
de um linho sem igual no mundo, bordados e rendados pelas mulheres para as corridas
de cavalo das festas de primavera. "Eu já sabia sobre esses tecidos, por alto, porque
minha avó tem ascendência ucraniana e lá se faz um linho ainda artesanal", conta
Villela.
Como vimos, para Villela nenhuma roupa é igual à outra. Tapetes e colchas são
recriados em casacos. A cada peça, Villela resgata em matéria e memória suas origens
de influência na arte popular (a arte de rua) o caráter religioso, as procissões e festas
populares. (PEREIRA, 2011, p.122)

Assim, os trajes do espetáculo misturam tipos de bordado característicos de regiões e culturas diferentes. Sobre o ponto cruz característico do leste europeu, se aplicam pedrarias e lantejoulas, técnicas muito encontradas no Brasil em trajes de folguedo, como o Bumba-meu-

\footnotetext{
${ }^{98}$ Disponível em <https://www.visiteobrasil.com.br/sudeste/minas-gerais/festas-populares/conheca/folia-de-reisou-reisado $>$ Acesso em 30 Set.2018.
} 
boi, por exemplo. O estilo macunaímico identificado por Villela como característico do Brasil, aparece, portanto, também na escolha das técnicas de bordado.

Figura 70 - O soldadinho de chumbo e a bailarina (2010)

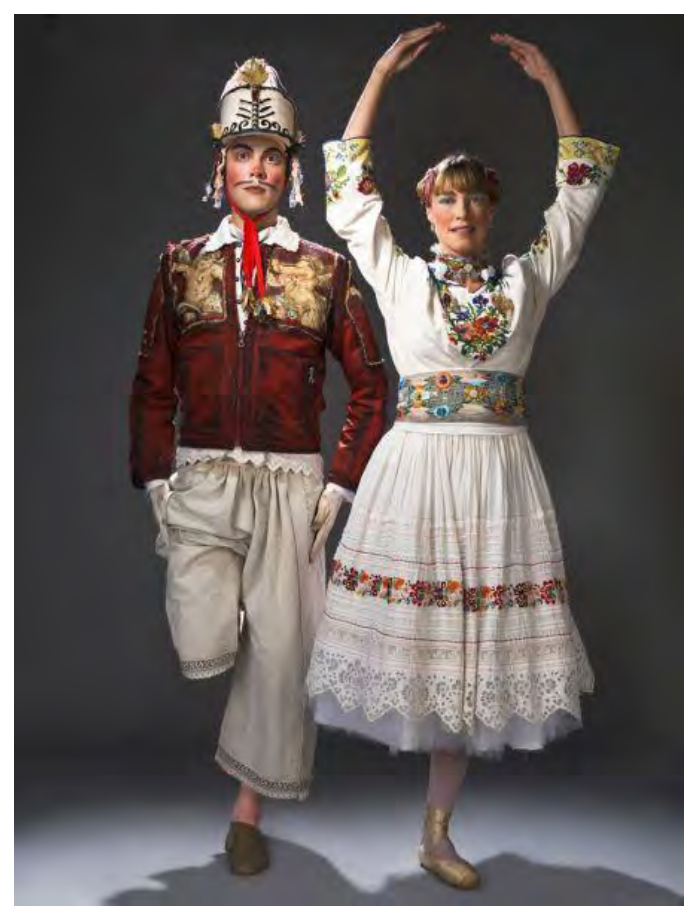

Fonte: Blog Thiago Tavares9
Figura 71 - Detalhes em pedrarias na gola e gargantilha.

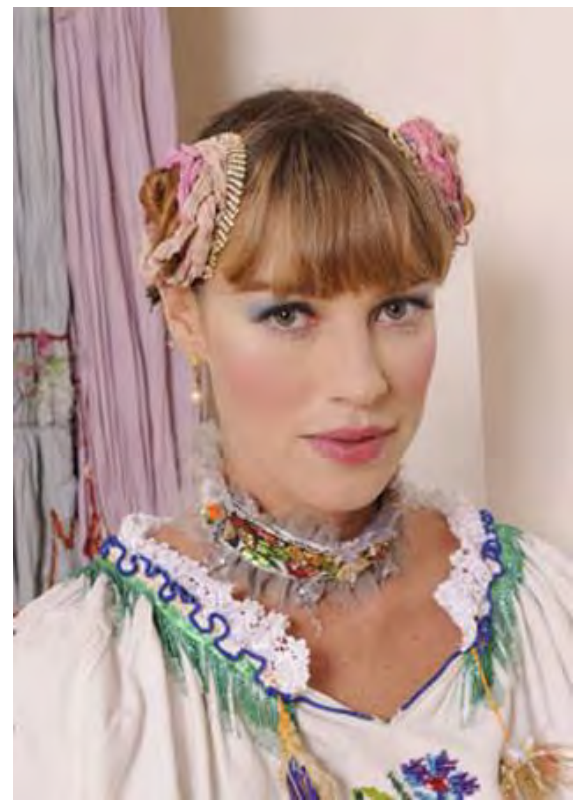

Fonte: Revista Quem ${ }^{100}$

Ainda seguindo a lógica do reaproveitamento e da ressignificação, Villela utiliza alguns dos trajes de O soldadinho e a bailarina em Gigantes da montanha (2013). Dando continuidade à parceria com o Grupo Galpão, o espetáculo, inspirado no texto de Luigi Pirandello (1867 1936), conta a história de uma companhia de teatro lutando para sobreviver e sua chegada a uma cidade mágica. Anteriormente, além de Romeu e Julieta (1992), Villela havia trabalhado com o Grupo Galpão por outra ocasião, no espetáculo A rua da amargura (1994). Este último, um espetáculo baseado no texto de 1920 O mártir do calvário, de Eduardo Garrido, escritor da virada do século XIX para o XX, que congregava as duas referências citadas como essenciais em Villela: os folguedos e a religiosidade.

Os trajes herdados da peça anterior foram rebordados e ganharam novos detalhes, como aplicações em chita e fitas de cetim, além de bordados que remetem a padrões e desenhos latinoamericanos. Além disso, neste espetáculo foram criados adereços de cabeça muito semelhantes

${ }_{99}$ Disponível em <http://actorsthiago26.blogspot.com/2010/10/o-soldadinho-e-bailarina.html> Acesso em 03 Out.2018.

${ }^{100}$ Disponível em: <http://revistaquem.globo.com/Revista/Quem/0,ERT127804-9531,00.html> Acesso em 03 Out.2018. 
aos chapéus de Sinhá Olympia. É mais uma homenagem explícita a esta figura inspiradora da vida de Villela.

Figura 72 - Trajes reelaborados em Gigantes da Montanha.

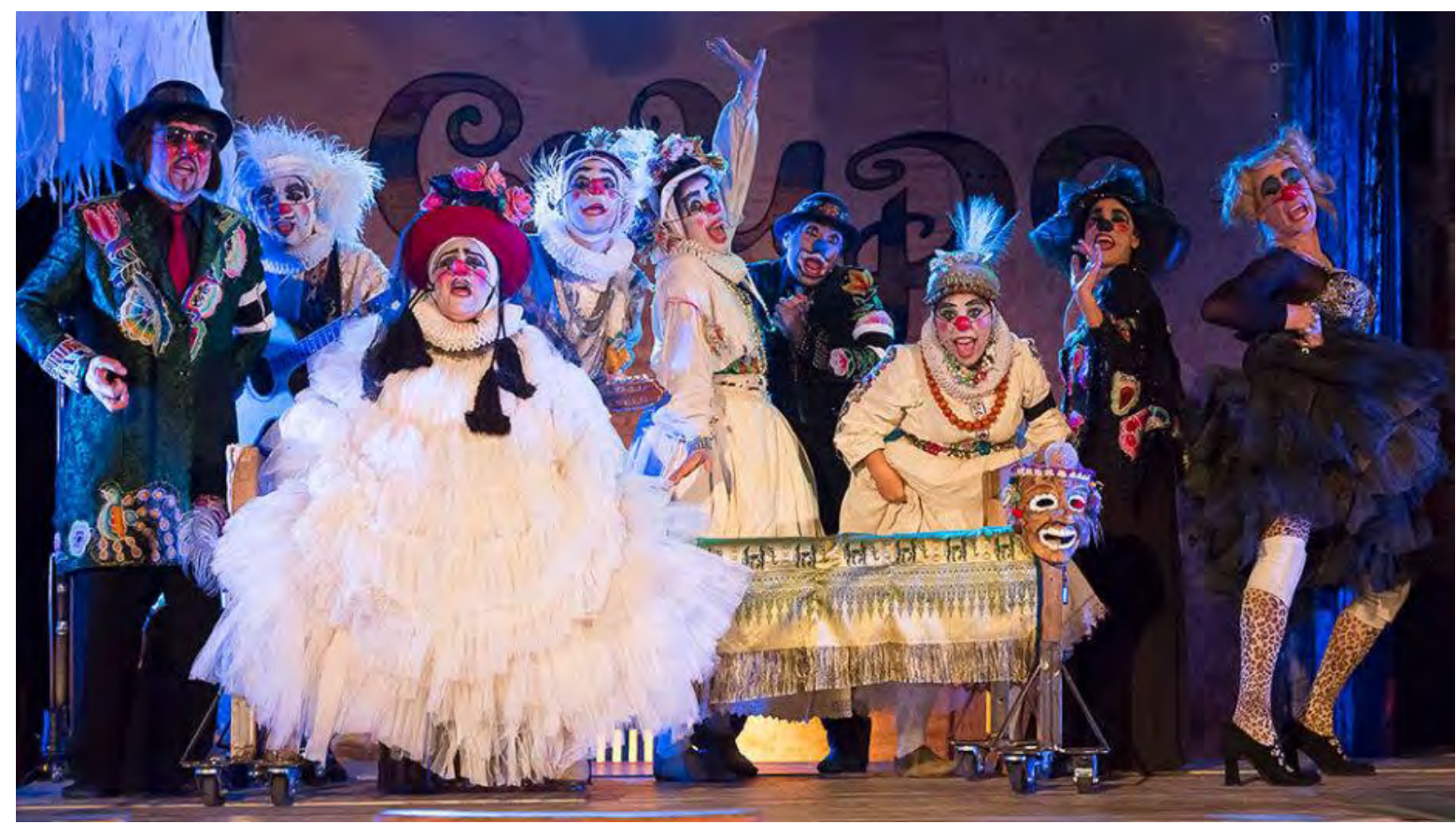

Fonte: Grupo Galpão ${ }^{101}$

Figura 73 - Sinhá Olympia.

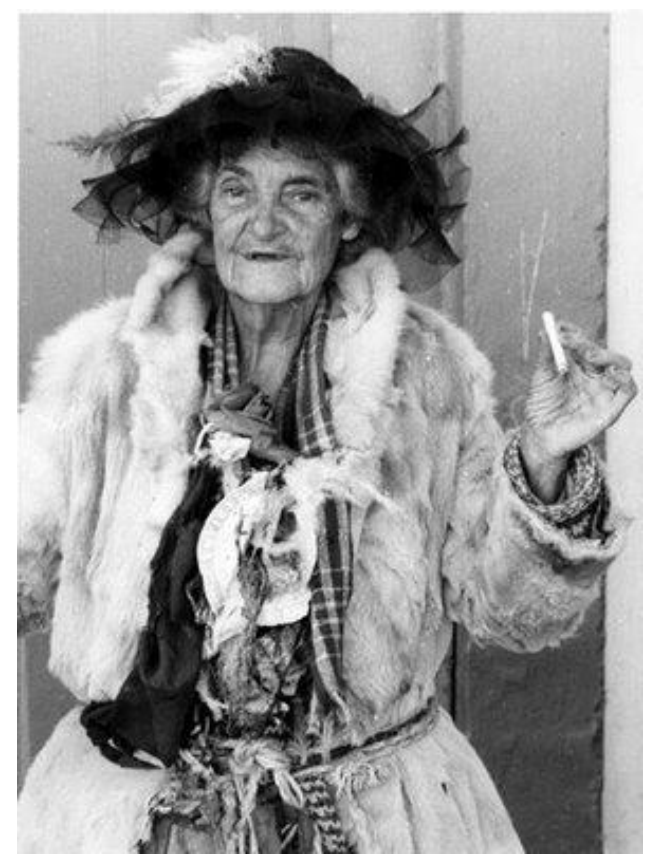

Figura 74 - Personagem com adereço inspirado em Sinhá Olympia.

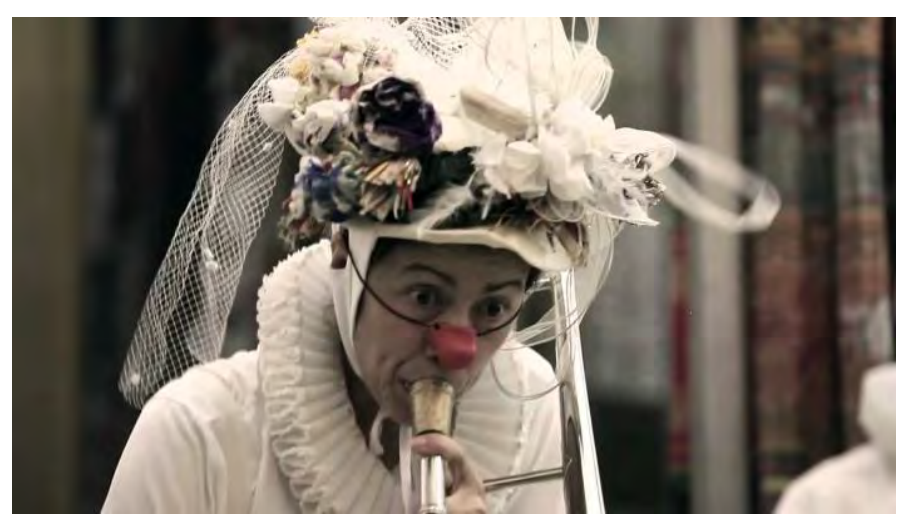

Fonte: Youtube ${ }^{103}$

Fonte: Site Sinhá Olympia ${ }^{102}$

${ }^{101}$ Disponível em: <http://www.grupogalpao.com.br/os-gigantes-da-montanha/> Acesso em 03 Out.2018.

${ }^{102}$ Disponível em: $<$ https://tccolympia.wordpress.com/> Acesso em 03 Out.2018.

${ }^{103}$ Disponível em: <https://www.youtube.com/watch?v=HLEQUFZkU1g> Acesso em 03 Out.2018. 
Esta união entre os folguedos e o místico gera trajes de cena com forte potencial ritual. Para Pereira (2012) há no trabalho com o Grupo Galpão um exemplo desta questão:

Os atores do Galpão quando vestem os trajes de cena saem fazendo uma festa de rua em estado de celebração e de festividade, intensificando a potencialidade ritualística do traje e se servindo do mesmo como uma ferramenta de transcendência no rito teatral. (PEREIRA, 2012, p. 55)

O bordado integra este aspecto ritual do traje, pois ao mesmo tempo que remete à tradição e à cultura de origem do encenador também é capaz de conferir novos significados ao traje. Transforma trajes que eram de um personagem em outro e elabora novas narrativas, criando um novo figurino através da mesma peça.

\subsubsection{Memórias}

O bordado não é apenas referência regional à origem mineira de Gabriel Villela. A técnica esteve também muito presente na vida de Gabriel Villela por conta de sua família, principalmente a partir da convivência com duas pessoas: a tia e a mãe. Sua tia Zilma era modista e desde criança Villela conviveu em meio a seu ateliê. Foi ela quem deu seus primeiros contatos com tecidos e texturas (Villela in Muniz, 2004, p. 185). Para a mãe, os têxteis foram a fonte de sustento principal da família após a perda do sustento da família pela agricultura. Ela produzia vestidos de noiva e enxovais, bordados e costurados à mão. Os filhos ajudavam na convecção das peças e aprenderam diversas técnicas de bordado e costura. Segundo ele:

\footnotetext{
A hidrelétrica de Furnas represou o nosso rio e sofremos uma falência generalizada na família, porque as terras cultiváveis ficaram embaixo da represa. A salvação da lavoura, naquele instante, vinha da agulha de minha mãe, que começou a bordar vestidos, enxovais de noiva e de criança, num período que não havia confecções e o bordado reproduzia a vontade e imaginação de quem o encomendava. Ela tinha esse talento espontâneo e se especializou: era da agulha, do PONTO RICHELIEU, PONTO SOMBRA ${ }^{104}$, PONTO PARIS ${ }^{105}$, PONTO AJOURS ${ }^{106}$, BORDADO MATIZADO $^{107}$... Cada filho pegava um lado fa roupa para ajuda-la a bordar e muitas vezes sentávamos todos em volta de uma saia de noiva. (...) Mas essa experiência me deu a oportunidade de conhecer um bordado do lado avesso, e acho isso fundamental para um figurinista. (VILLELA apud MUNIZ, 2004, p. 185, grifo do autor)
}

\footnotetext{
${ }^{104}$ Ponto sombra é um ponto de bordado realizado pelo avesso do tecido. Desta maneira, quando se olha o trabalho pelo lado direito, vê-se apenas a sombra da linha.

105 Ponto paris é uma espécie de bainha, normalmente usada para prender dois tecidos. Borda-se delicadamente pela beirada do tecido sem desfiá-lo.

106 Ponto ajours é um modo de fazer bainha. Consiste em desfiar uma parte do tecido e bordar neste desfiado, deixando alguns espaços vazados. Normalmente é feito com o próprio fio retirado ou outro de mesma cor.

${ }^{107}$ Bordado matizado preenche espaços inteiramente com linhas de cores diferentes, muitas vezes em degrade.
} 
Hoje, quem perpetua a tradição familiar junto com ele é a irmã Giovanna Vilela, com quem trabalha há mais de vinte anos. Ela trabalha produzindo os bordados dos trajes de cena. São de sua autoria os bordados dos espetáculos O soldadinho e a bailarina (2010), Os Gigantes da Montanha (2013), Mania de Explicação" (2014) e A Tempestade (2015). Em entrevista à Folha Revista ${ }^{108}$, Giovanna (2015) conta que aprendeu o ofício do bordado com a mãe quando ainda era pequena. Sua especialidade é o bordado livre manual, mas ela também trabalha com bordado de pedrarias, retalhos, recortes, etc. Ela produz as obras no ateliê da fazenda da família, em Carmo do Rio Claro.

Figura 75 - Detalhe bordado por Giovanna em traje de A Tempestade (2015)

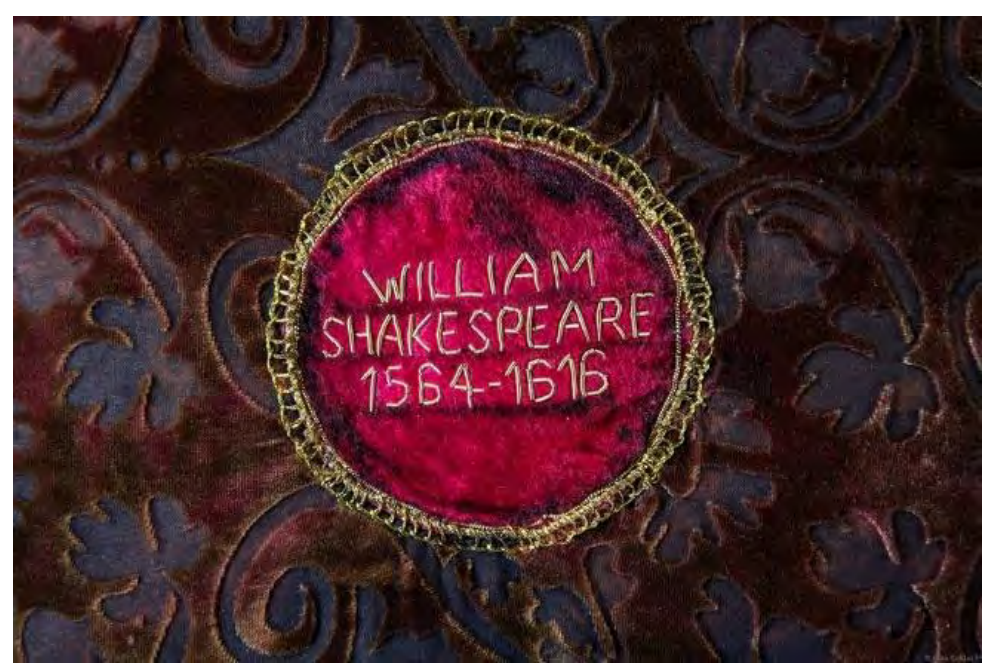

Fonte: Página do espetáculo no facebook ${ }^{109}$

O trabalho de Giovanna é lento. Para produzir os cerca de quarenta trajes de A Tempestade (2015), espetáculo criado a partir do texto de William Shakespeare, ela levou em torno de seis meses, sendo que alguns trajes chegaram a levar dois meses para ficar prontos. Isso ocorre principalmente porque o resultado nunca é imediato ou totalmente premeditado. Muito da criação se dá aos poucos e vai surgindo conforme a peça é feita. Além disso, segundo ela, como o figurino é parte da construção das personagens, muitas vezes um traje é bordado e rebordado de acordo com o andamento dos ensaios e a necessidade dos atores. Especificamente neste espetáculo, Villela volta às tradições mineiras do artesanato de barro e, portanto, os bordados foram em sua maioria confeccionados em tons terrosos.

\footnotetext{
${ }^{108}$ Disponível em: <https://www.facebook.com/atempestade2015 > Acesso em 03 Out.2018.

109 Ibidem.
} 
Figura 76 - A Tempestade (2015).

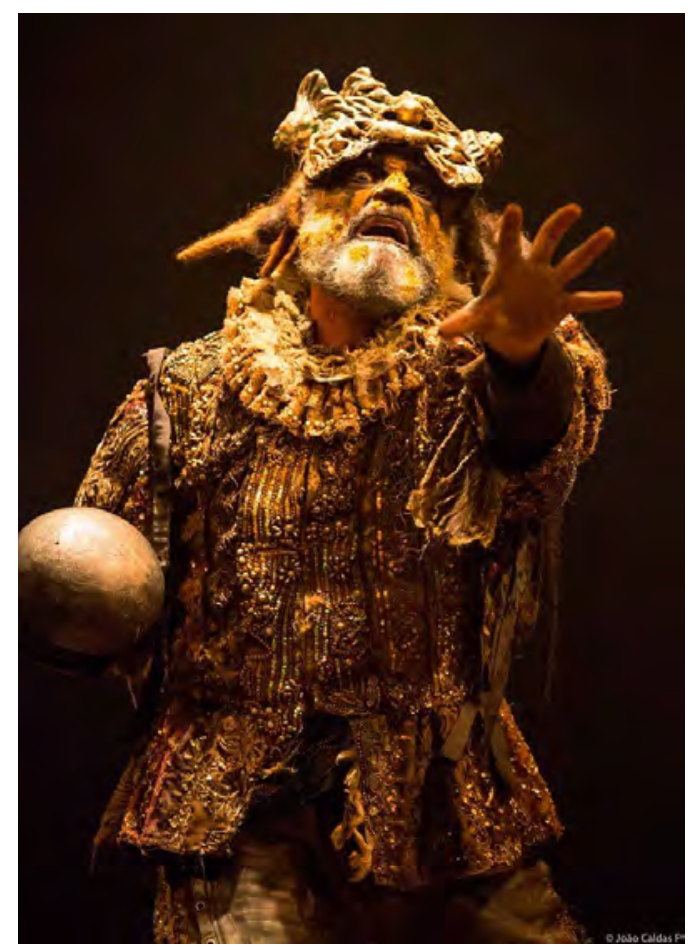

Fonte: Página do espetáculo no facebook ${ }^{110}$

Como para muitas famílias, o bordado é parte de uma tradição pessoal da família de Villela. É uma técnica que dialoga com as memórias e histórias de pessoas do mesmo círculo familiar ou de convivência. Por isso, além de remeter a uma ideia de brasilidade, o bordado na obra de Gabriel Villela abre espaço para dialogar com as memórias pessoais do espectador. Quando entram em cena, aqueles bordados não remetem somente a uma história do artesanato no Brasil ou em alguma região específica, mas sim a uma lembrança da história de quem vê a peça. É comum entre as pessoas de um país em que o bordado é tão presente no cotidiano que haja memórias ou passagens ligadas à execução dessa arte têxtil: uma avó que ensinou o ofício, um vestido de noiva, um parente que tinha grande habilidade com as linhas. O bordado pode fazer um resgate da memória afetiva e criar, assim, outros significados não planejados na percepção do espetador. A partir do universo poético criado por Villela, parte da construção pode estar nos olhos e nas memórias de quem vê.

\footnotetext{
110 Ibidem.
} 


\subsection{Poéticas têxteis}

A partir dos estudos de caso e da própria história do bordado, parece ficar evidente que o trabalho artesanal carrega em si uma série de significados. Estes significados podem remeter à origem ou história da técnica, à relação do artista com a técnica e, quando se pensa em trajes de cena, ao que o bordado se relaciona no palco e quais narrativas ele também é capaz de produzir. Neste sentido, o bordado pode ser capaz de construir no traje de cena uma poética têxtil.

É preciso, quando se fala nessa expressão, pensar primeiro na definição da palavra "poética". Muitas vezes, poética é usada como sinônimo para "estilo". É bastante comum encontrar expressões como "a poética de um artista" e derivados para fazer referência ao conjunto de criações de um artista e os elementos comuns que dá unidade às suas obras - sejam esses elementos concretos ou abstratos. Apesar de válido, este uso do senso comum não abarca as demais possibilidades que este termo pode significar, tampouco as outras gamas de sentido possíveis quando se fala em poética têxtil.

Claro que, num aspecto individual, a maneira com que um criador desenvolve sua maneira particular de trabalhar os têxteis é importante. O que se frisa, aqui, é que o essencial para conferir significado ao um traje não é necessariamente o resultado final, mas sim a maneira com que ele foi criado. Um criador como Gabriel Villela, por exemplo, que reutiliza trajes criados para outros espetáculos e os modifica adicionando elementos novos, como bordados e aplicações, está criando uma camada nova de significados e trazendo novos aspectos ao traje.

A palavra "poética" vem de poiesis, palavra do grego que significa "fazer" ou "criar" (Pantouvaki, 2014). Em entrevista para a Revista Novos Olhares, o Professor Eduardo Peñuela Cañizal (2001) diz, sobre o conceito de poética:

Eu me filio àquele tipo de pensamento em que se entende poética como a disciplina que estuda os pressupostos invariáveis de considerável conjunto de processos de ruptura ou alotropia, isto é, de fenômenos que alteram as formas expressivas e semânticas dos componentes de um sistema de signos qualquer. Os efeitos dessas transgressões se fazem sentir em unidades morfológicas ou sintáticas e, também, nos enunciados de uma frase ou de um relato. (...) Dessa perspectiva, parece-me mais coerente falar da maneira como o artista manipula o molde e não que o artista possui uma poética particular. (CAÑIZAL, 2001, p.30)

Mais do que um estilo ou unidade estética entre as obras de artista, o bordado nos trajes de cena parece se filiar a uma preocupação com os processos criativos e produtivos empregados para a criação de um todo. É importante pensar a questão, portanto, sob uma perspectiva 
fenomenológica, ou seja, entender como estes processos influenciam no resultado final e como são percebidos pelo artista, pelo ator e pelo público.

Pensar em poéticas têxteis é, de certo modo, um recorte analítico para que se possa aprofundar mais no tema dos processos envolvendo as escolhas têxteis e o modo como são trabalhados os tecidos, linhas, lãs e de toda sorte de material do gênero. Para Prain (2014), o trabalho com os têxteis guarda muitas histórias possíveis:

Sistematicamente sub-representados na história da arte, os têxteis frequentemente carregam as histórias daqueles que a sociedade costuma negligenciar: mulheres, crianças, escravos, imigrantes, povos aborígenes, fonas de casa, pais que ficam em casa, doentes, desaparecidos, desterrados e sofredores, fazemos um desserviço a nós mesmos quando ignoramos o fato que os têxteis têm papel importante no contar de nossas histórias. Tricô, tapeçaria, bordado - não importa qual é o meio, os têxteis são ao mesmo tempo produtos e geradores de narrativas. (PRAIN, 2014, 1. 172, tradução nossa)

Isto pode se relacionar tanto com a modelagem e construção do traje quanto com outros elementos têxteis - ou não - que são adicionados a ele: bordados, pedrarias, pintura, aplicação, colagem, entre outros. Nesta pesquisa, o interesse principal está nas poéticas têxteis que surgem dos processos que envolvem a artesania do bordado. Uma arte tão presente no cotidiano guarda em si e nas suas possibilidades de uso a potência para muitos significados. Aquilo que o bordado pode representar ou as histórias que ele pode narrar em cena dependem não só da intenção do artista como também da percepção da plateia. E é neste jogo que os significados possíveis se multiplicam. 
Capítulo 3

Exercício prático: A mulher como campo de batalha 


\subsection{O bordado e as mulheres}

Por entender que apenas a reflexão teórica não seria suficiente para estudar os usos do bordado, optou-se por realizar também exercícios práticos de criação que envolvessem os aspectos levantados na pesquisa. Para isso, foi escolhida a peça A mulher como campo de batalha (1996) de Matéi Visniec, como ponto de partida para as discussões e experimentações propostas na pesquisa.

Antes de adentrar de fato na análise descrição da peça A mulher como campo de batalha e da descrição do exercício proposto a partir dela, é preciso que se faça um preâmbulo para fins de justificativa. Ficou claro que, ao propor estudos sobre o bordado, seria importante partir de temáticas que estivessem ligadas à condição da mulher, uma vez que as artes têxteis foram ao longo do tempo frequentemente associadas e produzidas por mulheres. Em A da mulher como campo de batalha, há não só a discussão da situação da mulher em contextos de guerra, como também no cotidiano, levantando tópicos como a violência de gênero e a posição da mulher na sociedade.

Há diversas teorias do porquê os trabalhos têxteis - e por extensão o bordado - teriam sido deixados a cargo das mulheres em tantas sociedade e momentos históricos. Segundo Barber (1995) há uma razão principal que leva à distinção de gêneros no trabalho: não é uma questão de habilidade, mas sim de conveniência. Ao se pensar no início da vida sedentária do ser humano, no Período Neolítico (8.000 a.C. - 5.000 a.C.), parece ter havido uma divisão de funções de acordo com o que seria mais conveniente para a comunidade. Como as mulheres eram as que engravidavam e os bebês humanos dependiam da mãe por algum tempo após o nascimento, inclusive para alimentação, era preciso que elas realizassem atividades que as permitissem ficar mais tempo em locais protegidos, ou seja, trabalhos mais domésticos. Entre as principais funções domésticas estavam a plantação, o preparo dos alimentos e os trabalhos têxteis; não por acaso "estas são funções que as sociedades ao redor do mundo vieram a entender como centrais no trabalho feminino (ainda que outras tarefas possam ser adicionadas ao grupo, dependendo das circunstâncias de uma sociedade em particular) " (Barber, 1995, 1. 7).

Este não é, evidentemente, o retrato das sociedades contemporâneas. Ao longo do tempo, foram criados uma série de mecanismos sociais que permitem maior flexibilidade na fixação de papeis e ocupações como masculinos e femininos. Como muitos costumes e comportamentos, porém, a delegação dos trabalhos têxteis às mulheres assumiu uma ideia de "naturalização", ou seja, passaram a ser encarados como habilidades inatas femininas. Como dito por Barber (1995), não há, em princípio, características que tornariam mulheres mais hábeis 
ao trabalho com os têxteis do que os homens. Independente disso, os homens se relacionaram menos com essas funções ao longo do tempo ou, quando esta relação existia, parece haver uma diferença essencial entre o modo como ela se dava.

No governo de Elizabeth I (1533 - 1603), por exemplo, a Worshipful Company of Broderers, companhia de bordadores que existia pelo menos desde o século XIV, foi reconhecida como parte das empresas que serviam à coroa em $1561^{111}$. Esta associação exclusiva para homens que trabalhavam com bordado no período demostra que se por um lado a técnica era comum a homens e mulheres, para os homens ela representava um trabalho artístico, reconhecido e remunerado, enquanto que para mulheres era tratada como um trabalho doméstico. $\mathrm{O}$ bordado era considerado uma atividade essencial às mulheres, sendo ensinada desde a infância para elas, independentemente de sua classe social. Segundo Watt (2010), possivelmente o que diferencia o trabalho com o bordado entre tão diferentes pessoas é o objetivo com que a técnica era aplicada:

\begin{abstract}
Jovens mulheres que tinham que produzir seus próprios trajes e objetos têxteis domésticos, bem como ganhar dinheiro com isso, aprendiam técnicas mais básicas e práticas de bordado. As filhas da nobreza rural e urbana avançavam para pontos decorativos mais elaborados, como parte de sua preparação para o futuro papel de senhoras de grandes casas. Em um tempo em que todos os têxteis eram feitos e decorados à mão, habilidades com a agulha eram necessárias em todos os níveis sociais. Louvores eram dados a jovens mulheres que fossem excelentes no bordado; era visto como um indicador de sua piedade e diligência. (WATT, 2010)
\end{abstract}

Independentemente de ser realizado por homens ou por mulheres, na revolução industrial o bordado, junto com as outras técnicas artesanais, se vê em um ponto de virada. Aquilo que era produzido de maneira artesanal, cada vez mais podia ser produzido de maneira industrial, ou seja, mais barata e rápida. Além disso, o industrializado atraía, pois era um símbolo de progresso e novidade. Os trabalhos feitos à mão de maneira artesanal foram sendo desvalorizados em grande escala e ficaram restritos aos consumidores de alto poder aquisitivo que buscavam exclusividade.

Se por um lado, o bordado como ofício de um artífice foi perdendo espaço com a industrialização dos processos, houve um espaço em que o bordado não se perdeu: o doméstico. A diferença, assim como no Período Elizabetano, era que no âmbito interno dos lares, o bordado era uma prática feminina. Ainda que não houvesse leis proibindo que mulheres trabalhassem nas oficinas, há séculos o modelo ideal de feminilidade envolvia ficar dentro de casa e tudo o que isso envolvia: a costura, a cozinha, o cuidar dos filhos, etc. Mesmo pré-revolução industrial,

${ }^{111}$ Disponível em: <http://www.broderers.co.uk/> Acesso em 02 Out.2018. 
já se fazia uma diferença entre o trabalho masculino e feminino no campo dos têxteis. Segundo Stalinbrass (2016):

\begin{abstract}
“A própria generificação da roupa e das atitudes para ela torna-se materialmente marcada pelas relações sociais pelas quais, fora do mercado capitalista (no qual o tecelão e o alfaiate do sexo masculino iam se tornando a norma), as mulheres eram tanto material quanto ideologicamente, associadas com a confecção, o conserto e a limpeza das roupas." (STALLYBRASS, 2016, p.26)
\end{abstract}

O bordado era mais do que uma prática feminina simplesmente: era um traço de nobreza. Parker (2010) diz que o bordado combina a humildade da costura com a riqueza dos trabalhos com fios. Conota opulência e obediência. Assegurava às mulheres horas em casa, retiradas na privacidade, mas fazia uma declaração pública da posição do dono da casa e da condição financeira (PARKER, 2010, p. 64). Uma casa cheia de bordados era uma casa em que a mulher não precisava trabalhar fora e podia dedicar-se à vida do lar. Isso significava que o homem da casa tinha bons ganhos financeiros e podia sustentar sua família. Essa condição doméstica do bordado e sua ligação com o feminino também será uma das razões possíveis pelas quais a técnica foi sendo considerada artesanato e não arte ${ }^{112}$.

Mas ainda que o bordado tenha sido companheiro de confinamento das mulheres por muitos anos, ele também foi fonte de renda de muitas que vendiam - e até hoje vendem - suas obras bordadas. Justamente por ser uma atividade cotidiana, era possível comercializá-lo a um preço acessível à classe média burguesa que, após a revolução industrial, buscava acesso às artes. Principalmente no sec. XIX, muitas mulheres da classe trabalhadora ajudaram a manter suas casas através da venda de bordados. Segundo Cluckie (2008):

(...) o bordado provia emprego para numerosas mulheres, assim provendo também sua independência, ganhos financeiros e empoderamento. Para isso, o bordado tinha que se tornar uma arte democratizada, comercialmente viável, uma commodity disponível para a classe média consumidora. (CLUCKIE, 2008, 1. 638)

Numa perspectiva dialética, portanto, a ligação entre as mulheres e os têxteis promoveu tanto uma restrição a ambientes domésticos e às artes aplicadas, quanto fortaleceu as relações de grupo femininas e lhes deu fonte de subsistência. Para muitas culturas, o trabalho têxtil coletivo representava uma possibilidade de fortalecimento de relações e permanência de tradições. Para Machado (2003):

\footnotetext{
112 Evidentemente, outras razões levam a essa separação. Há a própria construção da ideia de artista do sec. XVIII; a ideia de que arte é algo elevado e não do cotidiano, etc. Porém, é inegável que há uma hierarquia nas produções de homens e mulheres.
} 
“(...)esse processo reforçou também as comunidades femininas, de mulheres que passavam o dia reunidas, tecendo juntas, separadas dos homens, contando histórias, propondo adivinhas, brincando com a linguagem, narrando e explorando as palavras, com poder sobre sua própria produtividade e autonomia de criação." (MACHADO, 2003)

Este caráter ambíguo é, possivelmente, um dos responsáveis pelo forte aparecimento do bordado como plataforma para obras de arte de cunho questionador, principalmente no tocante ao gênero. Se no Capítulo 2 falou-se sobre o surgimento de uma possível poética têxtil, o bordado também parece se alinhar a uma tendência de tecer político. $\mathrm{O}$ termo, utilizado por Bryan-Wilson (2017) tenta abarcar as possibilidades revolucionárias e de ruptura dos trabalhos têxteis:

Com a frase tecer político não pretendo apenas sugerir como os têxteis tem sido
usados para avançar agendas políticas mas também indicar um procedimento de fazer
do material político: tecer como verbo transitivo. Referindo a outra palavra de raiz
latina, texere, afirmo que tecer político é dar textura à política, recusar binarismos
fáceis, reconhecer complicações: texturizado como irregular, mas também, como
mostrarei, como trabalhado de maneira tangível e mantendo em si alguns traços do
trabalho, seja ele suave ou rasgado. (BRYAN-WILSON, 2017, p.7)

Estas duas instâncias em que o bordado se encontra, a poética têxtil e o tecer político, foram norteadoras para o exercício que será descrito neste capítulo.

\subsection{A mulher como campo de batalha}

Matéi Visniec, autor da peça A mulher como campo de batalha nasceu em 1956 na Romênia. Segundo sua biografia em seu site oficial ${ }^{113}$, foi na escrita que Visniéc descobriu um espaço para a liberdade, através da resistência cultural a regimes totalitaristas. Com forte influência do surrealismo e do teatro do absurdo, o autor é um membro da chamada Geração Oitentista, movimento da literatura romena que ganhou reconhecimento nos anos 1980. Até 1987, Visniéc era majoritariamente conhecido pela sua produção poética; porém naquele ano, ele imigra da Romena para a França, onde conseguiu asilo político. É a partir do seu período de produção na França que seu trabalho como dramaturgo teatral se torna mais conhecido. É hoje um dos autores romenos com maior difusão no mundo.

Em A mulher como campo e batalha, Visniec apresenta duas personagens: Dorra, descrita como uma mulher "que fala com um sotaque do Leste Europeu", vítima de estupro durante a Guerra da Bósnia e Kate, descrita como alguém “que fala com sotaque Anglo-Saxão", que descobrimos ser uma terapeuta. Com cenas que intercalam monólogos e reflexões internas

${ }^{113}$ Disponível em: <http://www.visniec.com/biography.html> Acesso em 14 Mai.2018. 
das personagens e conversas com toques de surreal, a peça se passa num hospital psiquiátrico onde estão essas mulheres.

Num primeiro momento, se tem a impressão de que Kate está trabalhando no hospital em uma tentativa de curar Dorra de seus traumas; há cenas em que Kate relata em seu diário suas impressões e conversas com Dorra, em passagens repletas de jargões médicos, retratando o progresso do tratamento. No entanto, ao longo da peça, se compreende que ambas estão internadas no hospital por experiências traumáticas diferentes, ainda que ambas relacionadas com a guerra: Dorra por uma dificuldade de seguir a vida após as violências sofridas e Kate por ter tido um surto durante seu trabalho na Bósnia. Kate trabalhava em missões de paz, cujo objetivo era abrir as valas comuns em que eram enterrados os mortos durante a guerra para identificar quem eram essas pessoas e comunicar suas famílias.

Já Dorra está grávida após ter sofrido um estupro coletivo durante a guerra. Um dos crimes de guerra mais marcantes da Guerra da Bósnia foi a criação de campos onde as mulheres e crianças do grupo étnico bósnio eram mantidas prisioneiras e eram sistematicamente violentadas pelos soldados sérvios. Além de ser uma arma óbvia para subjugar a população, já que a violência sexual é historicamente uma maneira dos vencedores humilharem os perdedores em situações de guerra, o objetivo principal desses campos era o de promover uma limpeza étnica, obrigando mulheres a engravidarem dos soldados sérvios e, assim, terem filhos que não seriam mais bósnias. É isso que acontece com Dorra. Como a maioria das mulheres que viveram situações parecidas, Dorra não quer ter esse filho. A tomada de decisão da personagem de abortar ou não é trabalhada ao longo da peça até que, por fim ela decida manter e criar esse filho.

Guccini (2014) denomina um dos momentos do teatro de Visniec como ciclo da guerra $^{114}$. Segundo ele, há um momento da produção do autor em que ele se preocupa diretamente com os reflexos das guerras na vida pessoal dos indivíduos. O fim da União Soviética no início dos anos 1990 foi subseguido da eclosão de diversos conflitos bélicos entre etnias dentro dos diversos países recém-formados. Em 1991, a Iugoslávia começa a se dissolver; no mesmo ano tem início a guerra na Croácia e no ano seguinte, a guerra na Bosnia (então ainda Bosnia-Herzegovina). Para Guccini (2014):

(...) agora não era mais uma questão de liderar (como no ciclo da "terra") lutas políticas com linguagem profundamente alusiva, empregando alegorias e parábolas;

\footnotetext{
114 O autor ainda cita, no mesmo artigo, outros dois ciclos de Visniec: o ciclo da terra, cuja preocupação era a resistência cultural ao regime socialista; e o ciclo do céu, em que se dedica a investigar sentimentos e relações humanas. Neste trabalho, não nos estenderemos nestes ciclos, pois não são de pertinência para os exercícios propostos ao longo da pesquisa.
} 
nem uma questão de celebrar rituais de renascimento (como no ciclo do "céu") mas de penetrar na psicologia da guerra, onde "terra" e "céu" explodem misturando seus detritos. (GUCCINI In.: PUPPA, DE MARTINO e TONINATO, p. 35, 2014, tradução nossa)

Dentro desse ciclo da guerra, há duas peças em especial cujo olhar se volta para as experiências das mulheres com a guerra: além de A mulher como campo de batalha, há ainda "Nessuno ha il diritto di atraversare senza armi um campo di battaglia” (1992), sem tradução para o português, que lida com a espera de sete mulheres enquanto seus maridos estão na guerra. A peça, escrita e encenada em 1992 no Conservatório de Lyon e dirigida por Philippe Clément, lida com o conflito nos Balcãs de maneira oblíqua. Apesar de se passar no período da Primeira Guerra, há similaridades entre as situações e a própria posição do autor diante do conflito (GUCCINI, p. 36, 2014).

O olhar feminino sobre a experiência da guerra apresenta desafios aos autores e artistas. Svetlana Aleksiévitch, no primeiro capítulo do livro A guerra não tem rosto de mulher, conta que tinha o desejo de escrever um livro sobre a guerra, mas não sabia de que maneira o fazer. Ela havia sido bombardeada ao longo da vida por muitas informações sobre a guerra, mas todas vindas de relatos oficiais ou livros de história. Ela começou a pensar então em transpor o foco do livro do olhar masculino para o feminino, para tentar contar a guerra pela ótica das mulheres. Logo foi ficando claro que ela precisaria se valer de entrevistas e testemunhos dessas mulheres, tanto daquelas que haviam lutado no front quanto daquelas que tinham ficado para trás nas vilas e cidades, para compor seu texto.

O que foi se apresentando à Svetlana foi um quadro de narrativas e histórias que muito mais se preocupavam com impressões ligadas ao empírico e às sensações da guerra do que com uma pretensa fidelidade histórica. Mais de uma vez lhe disseram que queriam the contar a história de "minha guerra", ou seja, de sua experiência extremamente pessoal em relação a um fato que, para todos os efeitos, era histórico. Isso, porém, não o invalida como relato e documento sobre a guerra. Para Aleksiévitch (2016): As lembranças não são um relato apaixonado ou desapaixonado de uma realidade que
desapareceu, mas um renascimento do passado, quando o tempo se volta para trás.
Antes de mais nada, é uma criação. Ao contar, as pessoas criam, "escrevem" sua vida.
(ALEKSIÉVITCH, 2016, p.13)

Em A mulher como campo de batalha parte-se das experiências pessoais das personagens para se relatar fatos importantes da guerra. É a partir do que dizem Dorra e Kate que o leitor descobre sobre algumas das características mais marcantes do conflito interétnico nos Balcãs: os estupros coletivos e as valas comuns em que os corpos dos inimigos eram 
enterrados. Esta relação da obra com a memória foi um dos motivos de sua escolha para os exercícios propostos.

O bordado guarda uma relação estreita com a memória. Em português, há uma expressão que diz que quando há pessoas conversando e trocando histórias, na maior parte das vezes histórias secretas e fofocas, elas estão tricotando. Marjane Satrapi, escritora iraniana, conta que o termo para esse tipo de situação em sua língua é bordando. No livro "Bordados", Marjane relata uma dessas reuniões em que as mulheres de sua família se juntavam após algum evento e falavam sobre os assuntos que não podiam falar na frente de seus maridos: contam suas experiências com homens, com subversões à religião, desejos e preocupações. Bordar, nesse sentido, era reunir histórias. Se Dorra e Kate são duas mulheres que, por meio da narrativa de suas histórias, reelaboram suas experiências de modo a superar o trauma da guerra, o trabalho com os têxteis pode ser uma boa maneira de narrar visualmente e colaborar com a estética da peça.

Para Benjamin (2014) em seu famoso texto O Narrador, a narração não está necessariamente ligada a uma linearidade de eventos, mas sim à experiência e à oralidade. Diz Benjamin:

\footnotetext{
"O que separa o romance da narrativa (e da epopéia no sentido estrito) é que ele está essencialmente vinculado ao livro. A difusão do romance só se torna possível com a invenção da imprensa. A tradição oral, patrimônio da poesia épica tem uma natureza fundamentalmente distinta da que caracteriza o romance. $\mathrm{O}$ que distingue o romance de todas as outras formas de prosa - contos de fada, lendas e mesmo novelas - é que ele nem procede da tradição oral nem a alimenta. Ele se distingue, especialmente, da narrativa. O narrador retira da experiência o que ele conta: sua própria experiência ou a relatada pelos outros. E incorpora as coisas narradas à experiência dos seus ouvintes[grifo meu]." (BENJAMIN, 1994, p. 201)
}

O bordado parece se encaixar no tipo de experiência escrita por Benjamin como fonte do ato de narrar. Ele é um conhecimento que se transmitiu ao longo do tempo majoritariamente na oralidade. Pessoas que se uniam para trocar conhecimentos sobre o assunto; mães e avós que transmitiam o conhecimento para filhas e netas. Ele está intimamente ligado à memória, pois se constrói de maneira compartilhada e em grupo, a partir das vivências individuais de cada um.

É um sentimento muito comum em relatos e textos poéticos acerca de situações de guerra de que muitas vezes não se consegue colocar a barbárie em palavras. Como dito no Capítulo 2, muitos artistas produziram obras têxteis para tentar dar conta dessas experiências após a guerra. Através do bordado essas pessoas puderam lidar com o trauma da guerra, ao mesmo tempo em que se apoderavam de suas próprias narrativas acerca de suas experiências. 
A relação dos militares com o bordado foi ponto de partida para um possível uso quando tratando sobre a experiência da guerra.

Se a relação dos homens com o bordado era de terapêutica para reelaborar as memórias após a guerra, a relação das mulheres com o bordado era terapêutica principalmente durante a guerra. Os relatos que se dedicam ao olhar das mulheres sobre a guerra muitas vezes documentam um o reforço da ocupação das mulheres ao trabalho com os tecidos, por vezes até partindo do Estado. Para Bryan-Wilson (2017),

(...) o trabalho têxtil manual se tornou mais um costume simbólico, nostálgico e ritual que uma necessidade material. Nestas instâncias, os t^lexteis eram utilizados para manter ideologias patrióticas e reforçar os limites do comportamento "natural" ou "apropriado" para mulheres, particularmente no nascer de crises sobre masculinidade dos tempos de guerra. (BRYAN-WILSON, 2017, p.11)

Porém, parecem haver outras questões, de foro pessoal, envolvidas. O bordado parece se relacionar com como as mulheres se sentem em períodos de crise como este. Como fazer com que o tempo passe durante a guerra? Num evento majoritariamente entendido como um campo masculino, onde se colocam as mulheres? Parece haver duas funções principais para o bordado neste momento: ocupar a mente e transmitir sensação de normalidade.

A guerra muitas vezes para as mulheres é sobre esperar. Sobre estar distante do conflito e nada poder fazer para que ele cesse. No livro A casa das sete mulheres (2003) de Letícia Wierszchowski, por exemplo, há diversas passagens que demonstram a sensação das mulheres da família de Bento Gonçalves (1788 - 1847) durante a Revolução Farroupilha (1835 - 1845). O bordado era uma maneira de fazer com que a mente não ficasse tão ocupada com a guerra àespera da volta dos homens como quando diz que "A Virgem compreende os percalços daquela revolução, os sofrimentos femininos, a angústia costurada com a linha de bordados, a cruel sina daquela espera". (WIERSZCHOWSKI, 2003, p.309)

Há ainda a outra noção, a de normalidade, que é também expressa na obra de Aleksiévitch (2016):

Se tínhamos um minuto de descanso, bordávamos algo, um lenço. Nos davam tecido para servir de portianka ${ }^{115}$, mas nós criávamos cachecóis com eles, decorávamos com bordados. Queríamos fazer tarefas femininas. Sentíamos falta de coisas femininas, a situação toda era insuportável. A gente procurava qualquer pretexto para pegar a agulha e bordar algo, nem que fosse para passar um tempo em nossa forma natural. (ALEKSIÉVITCH, 2016, p. 139)

Este trecho faz parte do relato intitulado "Em nossa casa vivem duas guerras..." em A guerra não tem rosto de mulher. Nesse relato, Svetlana ouve a história de mulheres que

\footnotetext{
${ }^{115}$ Espécie de tecido que fazia as vezes de meia, usado pelos soldados soviéticos.
} 
estiveram na guerra durante o período do governo stalinista. Elas contam sobre como era difícil tentar esquecer que estavam rumando para batalhas e que sentiam falta de suas casas. Uma das estratégias encontradas por essas mulheres para não se deixar perder a razão numa situação de barbárie foi se voltar para uma atividade que lhes era cotidiana nos períodos de paz: o bordado.

Mas em A mulher como campo de batalha, o desafio era misturar as duas possibilidades do bordado, masculino e feminino. Dorra e Kate já não estão mais na guerra, mas sim após seu fim e ambas têm seus traumas e memórias a reelaborar. Ao mesmo tempo, estão isoladas e em situação de imobilidade. A guerra descrita na peça não é como a que das referências citadas. Não é uma guerra distante do quintal da família, que levou os homens para terras distantes. É uma guerra entre vizinhos, entre pessoas que se relacionavam. O olhar das mulheres sobre este conflito não é igual ao das mulheres que esperam. Seus corpos também fazem parte da batalha. Como então relacionar o bordado com personagens que assumiam ao mesmo tempo as perspectivas de quem sobreviveu à guerra e de quem a sentiu no isolamento? E como transmitir essa relação artisticamente?

\subsection{Exercício Prático - EACH}

Aqui se relatará o processo e resultados finais do primeiro exercício prático realizado. Este exercício foi realizado no $1^{\circ}$ semestre de 2017, com os alunos de graduação em Têxtil e Moda - majoritariamente dos $2^{\circ}$ e $3^{\circ}$ ano - durante a aula de Traje de Cena e Cenografia, ministrada pelo Prof. Dr. Fausto Viana, na EACH (Escola de Artes, Ciências e Humanidades).

A proposta era que o trabalho final da disciplina fosse a criação de um traje de cena baseado na peça "A mulher como campo de batalha". Esse traje tinha uma particularidade: ele deveria ser ao mesmo tempo parte do cenário e traje de cena. Para isso, se propôs a criação de paineis $(2,00 \mathrm{~m} X 1,40 \mathrm{~m})$ têxteis que comporiam o cenário e, em determinado momento da peça, seriam retirados das estruturas que os seguravam para se tornar trajes usados pelas personagens. Esses trajes deveriam contar com bordados como parte fundamental para a sua criação.

Para atingir esse objetivo, antes da criação do traje em si foram propostas algumas atividades para familiarizar os alunos com a técnica e a ideia geral da peça e da proposta de trabalho:

- Oficina 1 - bordado livre: Os alunos foram apresentados aos materiais para a realização do bordado livre e ensinados de três a cinco pontos básicos que permitissem maior possibilidade de criação. 
Esta etapa foi elaborada após a percepção de que a grande maioria da sala nunca havia tomado contato com a técnica do bordado. Para que o trabalho pudesse ser realizado com maior proveito, realizou-se um dia de oficina.

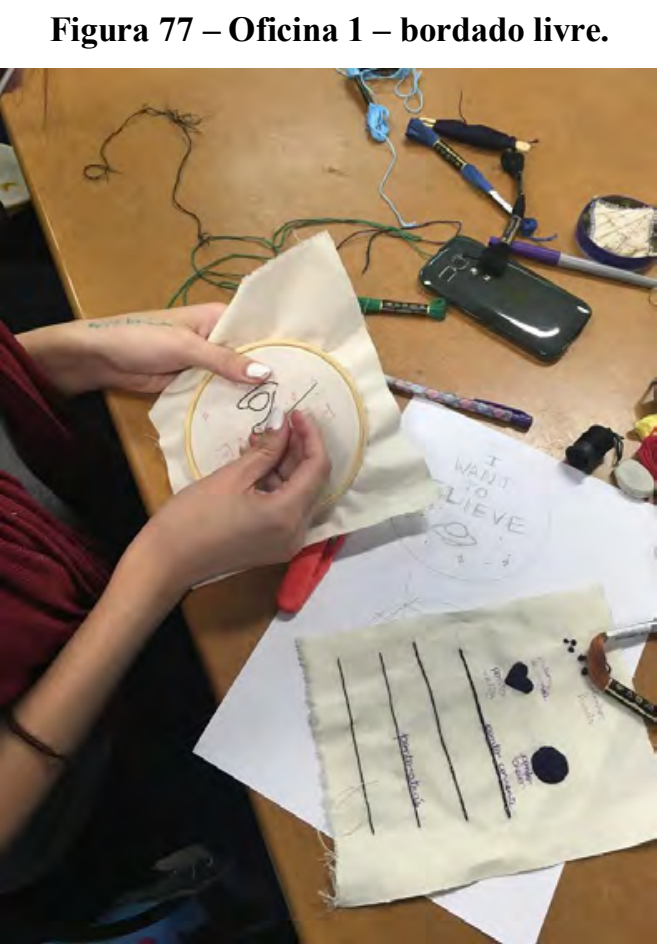

Fonte: Acervo da autora.

- Leitura da peça: Foi feita uma leitura branca da peça em sala de aula. Assim, os alunos podiam discutir entre si sobre os momentos que achassem relevante no texto, bem como o compreender melhor. Esta etapa foi mais longa, pois além da dificuldade já dada no texto, os alunos também promoviam discussões.

Cada grupo de alunos deveria escolher algum aspecto do texto ou alguma cena em especial para a realização do seu traje.

- Oficina 2 - Quadrados bordados: partindo de um corte de tecido quadrado de algodão cru $(0,4 \mathrm{~m}$ X $0,4 \mathrm{~m})$, os alunos deveriam pensar em alguma parte ou assunto que lhes tivesse chamado a atenção na leitura da peça e criar uma peça bordada. Além do bordado, o quadrado poderia contar com tinta, tecidos, fotos e outros materiais que o aluno achasse pertinente. Este trabalho também contaria com sons e aromas para compor uma obra que fosse sensorial. 
Figura 78 - Oficina 2 - Quadrados bordados.

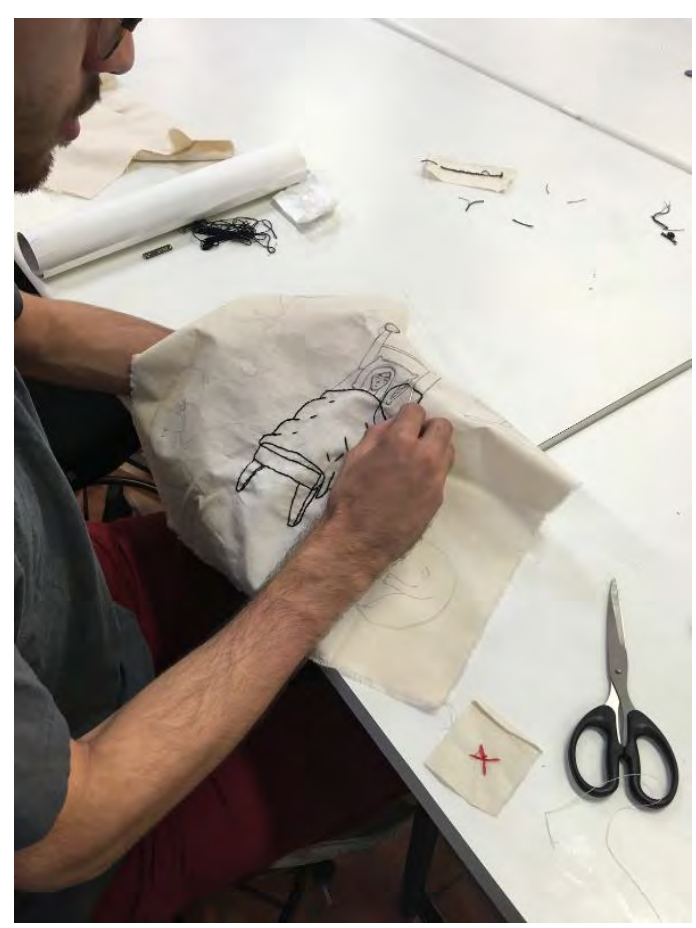

Fonte: Acervo da autora.

- Oficina 3 - Bordado sobre fotografia: a partir de um transfer de uma fotografia em um corte de tecido do mesmo tamanho do exercício anterior, os alunos deveriam criar uma obra que promovesse intervenções sobre a imagem. Essas intervenções deviam ser bordadas e podiam modificar a foto, complementá-la, etc. As imagens eram fotografias de guerra.

Figura 79 - Oficina 3 - Bordado sobre fotografia.

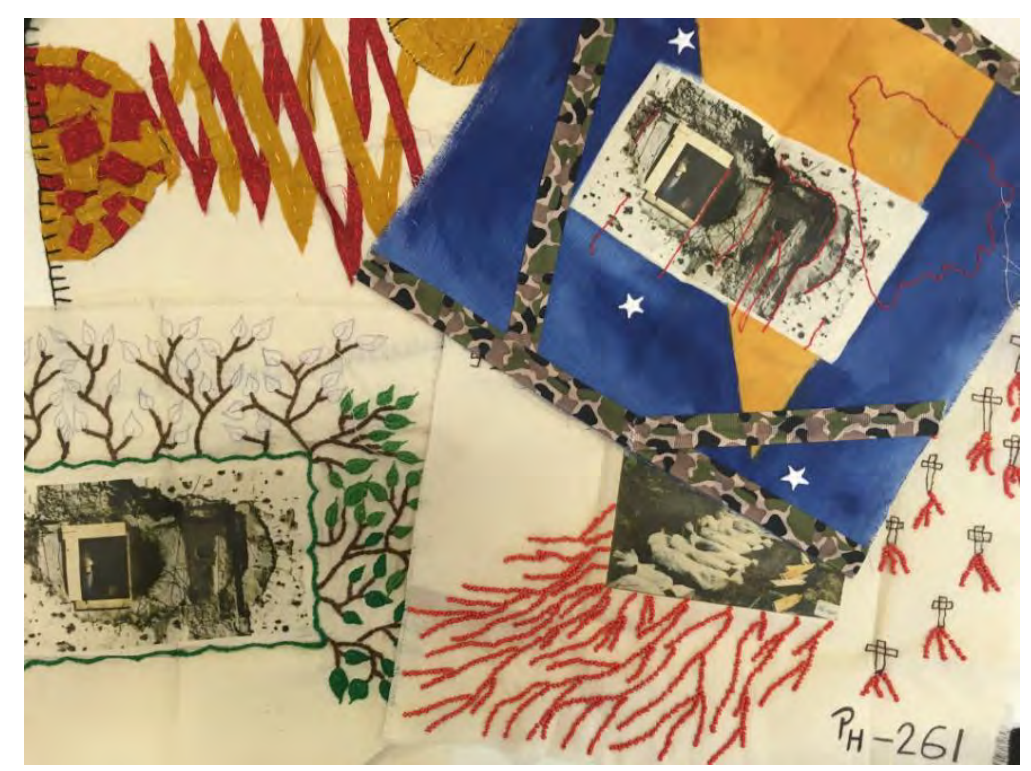

Fonte: Acervo da autora. 
Dando início ao planejamento e concepção do traje de cena para a peça em si, lhes foi pedido que pensassem em pontos e temas que mais lhes chamasse a atenção no texto e depois que se dividissem em grupos. Uma vez divididos, eles deveriam pensar em algum tema que achassem que permeava toda a peça e dividir o texto em partes guiadas por esse eixo temático.

Para definir melhor como seria o trabalho final, os alunos deveriam pensar em uma série de pontos sobre o traje de cena a ser criado:

- Conceito gerador: a partir do tema, os alunos deveriam desenvolver melhor a ideia, dizendo qual seria sua abordagem e quais aspectos seriam trabalhados.

- Como vestir/pendurar: por ser um trabalho que ao mesmo tempo deveria ser exposto (como cenografia) e usado no corpo (como traje de cena), era preciso um descritivo detalhado de como se dariam essas ações.

- Desenhos, materiais e cores: croquis dos dois momentos do traje, com amostras e referências.

- Orçamento: quanto seria o custo do trabalho como um todo.

No Anexo I se encontra um exemplo de projeto entregue pelos grupos.

Nos tópicos que se seguem, se apresentam exemplos de obras criadas por três grupos distintos. Estas obras parecem congregar as principais referências, usos do bordado e temas abordados pelos alunos como um todo.

\subsubsection{Obra 1 - Influência da moda}

A obra do Grupo 1 parte de uma interpretação bastante particular do texto. Neste grupo, os alunos entenderam que as duas personagens da peça eram uma só: Kate seria um alterego de Dorra, uma espécie de estratégia para conseguir lidar com seu trauma da guerra. Por isso, para esse grupo, a peça deveria ser um monólogo e a atriz deveria ter em seu traje elementos que remetessem à outra personagem - que só existia em sua mente.

Na parte de trás do traje, o grupo criou uma espécie de capa que ficaria fixa numa estrutura. $\mathrm{O}$ vestido usado pela atriz deveria começar o espetáculo amarrado nesta capa. A capa foi formada por diversos quadrados, ilustrados e bordados, tanto dos integrantes do grupo quanto de outros grupos. São os quadrados resultantes da Oficina 2 descrita no item 3.3. Os quadrados eram de passagens consideradas como as mais importantes para o grupo. Eram 
também as passagens que evidenciavam ainda mais o desequilíbrio de Dorra e poderiam ser indícios da não existência de Kate.

$\mathrm{O}$ traje criado pelo grupo se assemelha a um traje de noiva, porém na cor vermelha. $\mathrm{O}$ vestido feito em tule ficava levemente transparente (Figura 80). Além do próprio véu bordado em dourado, havia bordados pela saia de algumas das frases mais marcantes para o grupo na peça. O contraste proposital entre o véu com acabamento mais refinado e o vestido com rasgos e pontas destruídas acaba por demonstrar também a cisão interna da personagem.

Figura 80 - Traje do Grupo 1.

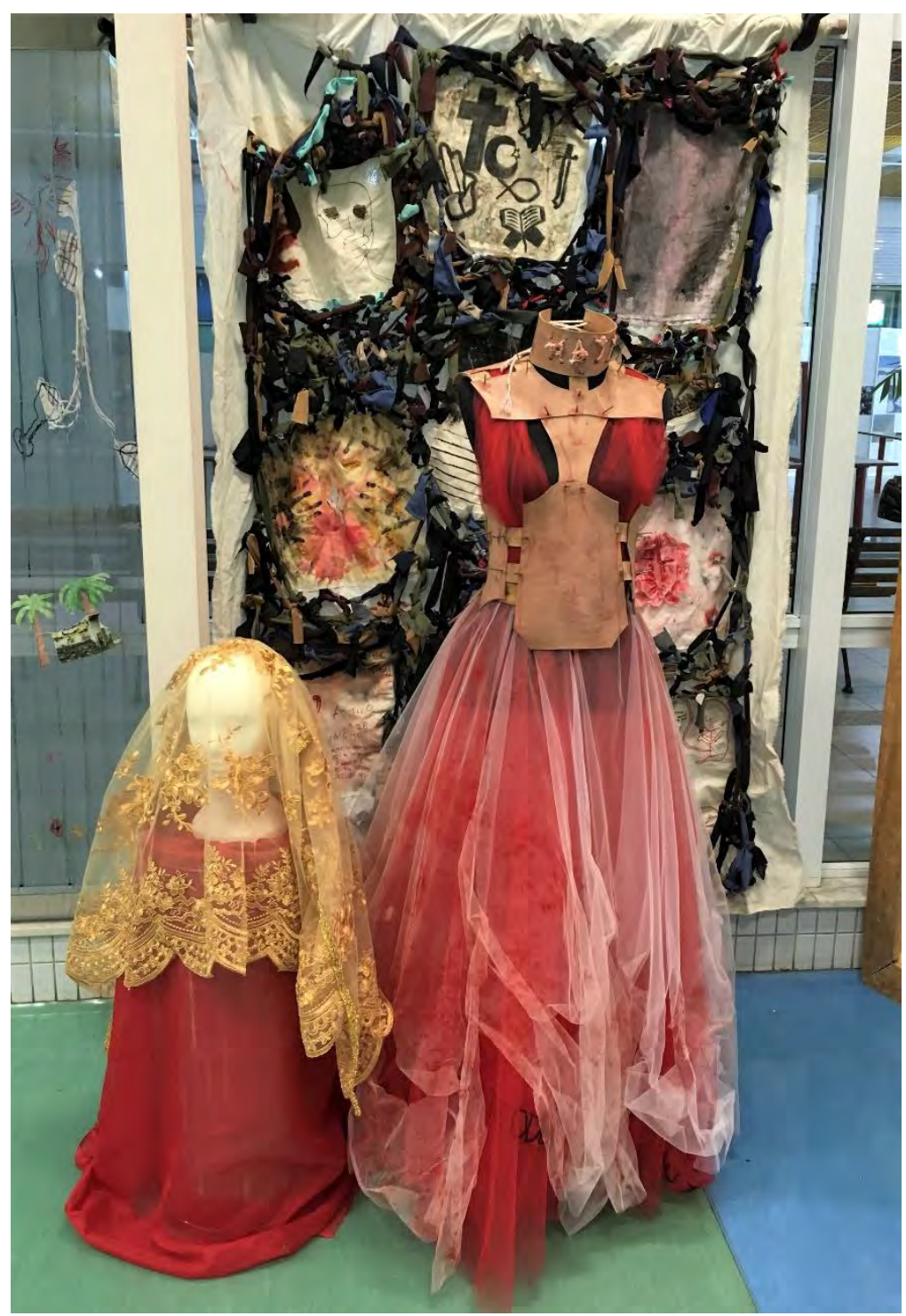

Fonte: Acervo da autora.

O grupo também criou uma espécie de colete que manteria a postura da atriz ereta. Era feito de couro com acabamentos em pregos e no pescoço estava bordado em barbante de tecido grosseiro o nome "Kate". A referência mais evidente para a construção deste colete parece ter sido os coletes ortopédicos usados pela pintora Frida Khalo (1907 - 1954). Em muitas pinturas, 
o colete aparece como um instrumento de dor e pesar para a pintora. O quadro A coluna partida (1944) em especial parece ter sido uma inspiração para o grupo, tanto pela modelagem do colete quanto pela presença dos pregos. $\mathrm{O}$ grupo parece ter identificado o sofrimento e imobilidade de Frida neste quadro com a situação de Dorra no pós-guerra.

Figura 81 - Quadro A coluna partida (1944), Frida Khalo.

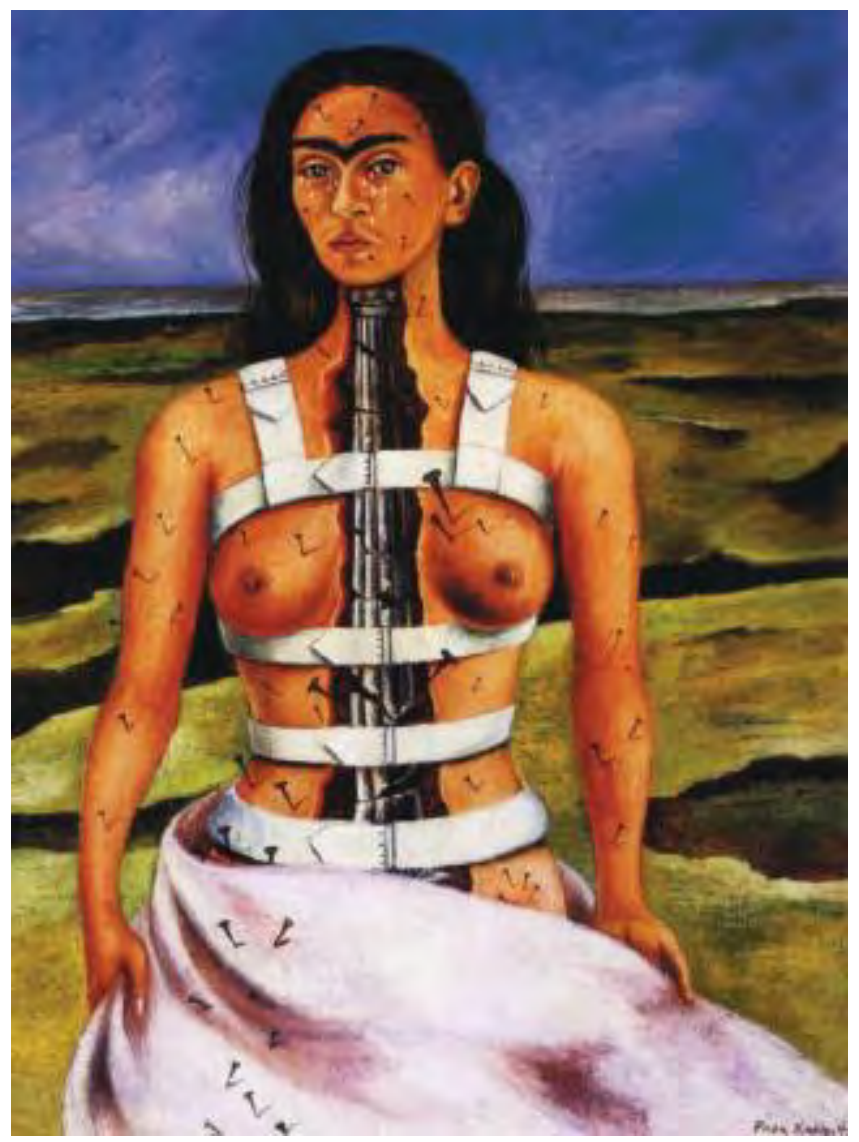

Figura 82 - Detalhe da Obra 1.

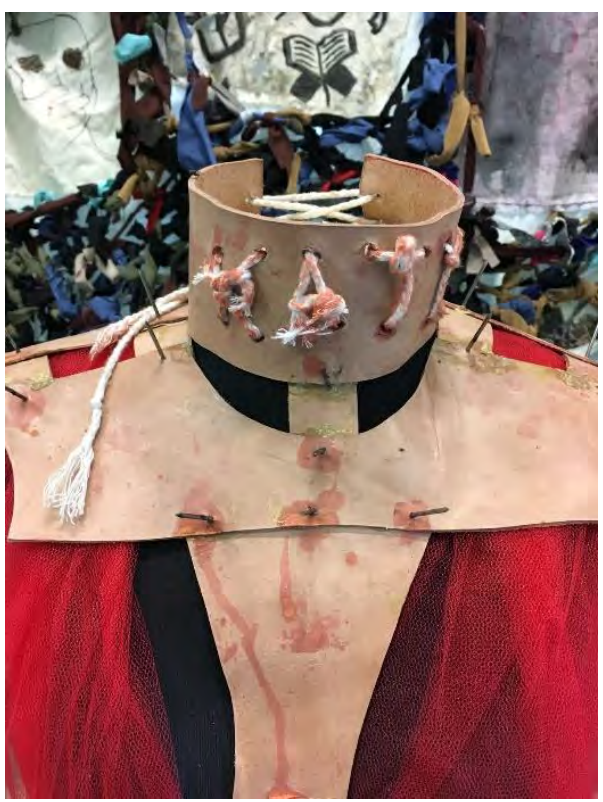

Fonte: Acervo da autora.

Fonte: Scielo ${ }^{116}$

Além disso, esse grupo possuía como característica pessoal uma forte influência da moda, principalmente da alta costura. Quando se trabalha com alunos de cursos de moda, muitas vezes fica claro que o campo de referências deles parte de um repertório ligado aos desfiles de alta costura e dos editoriais de moda. Muitas vezes, o comentário dos alunos é de que há algo de teatral nestas expressões da moda que os inspiram. O desafio quando se tem alunos com este perfil é deixar claro que ainda que se fale em uma característica teatral principalmente na alta costura, em que há um trabalho diferenciado na criação de trajes e na concepção dos desfiles, nem o desfile se torna teatro e nem os trajes figurinos nestas condições. O que ocorre é que a moda tende cada vez mais a experimentar novos meios de passar sua mensagem enquanto marca. Mensagens enquanto abstrações precisam ser traduzidas de maneira coerente em

${ }^{116}$ Disponível em: < http://pepsic.bvsalud.org/scielo.php?script=sci_arttext\&pid=S1516-36872016000200003> Acesso em 02 Out.2018. 
elementos concretos. Esses elementos passam desde a escolha de um espaço até uma música, um perfil de modelos, materiais usados nos trajes, etc. Isso não significa, no entanto, que o compromisso da marca deixou de ser com o consumo dos produtos - mais do que com as ideias. O desafio é fazer com que os alunos façam esse salto daquilo que pode ser referência partindo da moda para o que pode funcionar como traje de cena.

\subsubsection{Obra 2 - Bordado etnográfico}

O Grupo 2 entendeu que o mais importante era pensar na questão das guerras interétnicas nos Bálcãs, principalmente diante do quadro de crise de refugiados no mundo. Por isso, o grupo decidiu trabalhar não com as personagens da peça, mas sim com as diversas etnias mencionadas ao longo do texto. Seu trabalho consistia em um tecido amplo adornado com faixas. Cada uma dessas faixas continha bordados que fizessem referência ou a elementos da cultura de cada um dos povos representados ou a bordados típicos da região.

O leste europeu tem uma tradição antiga com os trabalhos têxteis, principalmente com o bordado e suas variantes. Segundo Leslie (2007):

Tradições culturais de trabalho com agulhas são especialmente fortes para o bordado em trajes regionais e têxteis domésticos. Outras técnicas com agulhas usadas no leste europeu são aplicações, renda, pedrarias e crochê. (...)

Motivos e padrões do Islã tiveram papel dominante no leste europeu, especialmente nas áreas que foram ocupadas pelos turcos, como a Bulgária e partes da Romênia e Iugoslávia. Há também forte influência de tradição católica e católica ortodoxa, mas elas não tiveram influência significativa nos bordados. Para todos os efeitos, mulheres são as bordadeiras no leste europeu, com exceção de têxteis eclesiásticos, que eram feitos por artistas profissionais homens. (...)

Cor é importante na cultura do leste europeu, como vermelho brilhante predominante. Vermelho significava inocência e contentamento com a vida, especialmente para mulheres jovens. Bordado era normalmente feito em linho cru ou tecido embranquecido, em linha de algodão, lã ou seda. Era normalmente trabalhado em faixas estreitas de motivos repetidos que decoravam as bordas de têxteis domésticos. Bordado era também importante para os trajes regionais das mulheres, enfeitando camisas, blusas, aventais, cachecóis, anáguas e chapéus. Em algumas áreas, chapéus masculinos, camisas e calças eram também decorados com bordado regional. (LESLIE, 2007, p. 68 - 69)

O grupo investiu em muitas dessas características apontadas como principais do bordado no leste europeu: três faixas representam as três religiões de maior expressão na região (cristianismo, judaísmo e islamismo); e os tons de vermelho predominam nas faixas bordadas, tanto em formas geométricas - outra característica dos bordados desta região - quanto nos elementos da natureza utilizados. Em contraste com as cores das faixas que representam as culturas, há um mapa contornado em preto da região dos Balcãs. Este mapa está sujo de terra, 
com marcas de mãos. Fica expressa neste contraste a situação de guerra em que o lugar se encontrava e as dificuldades de relacionamento entre os povos. Se sua tradição é a das cores e do trabalho têxtil, a guerra solapa tudo e transforma em ausência de cor e vida.

Figura 83 - Obra do Grupo 2.

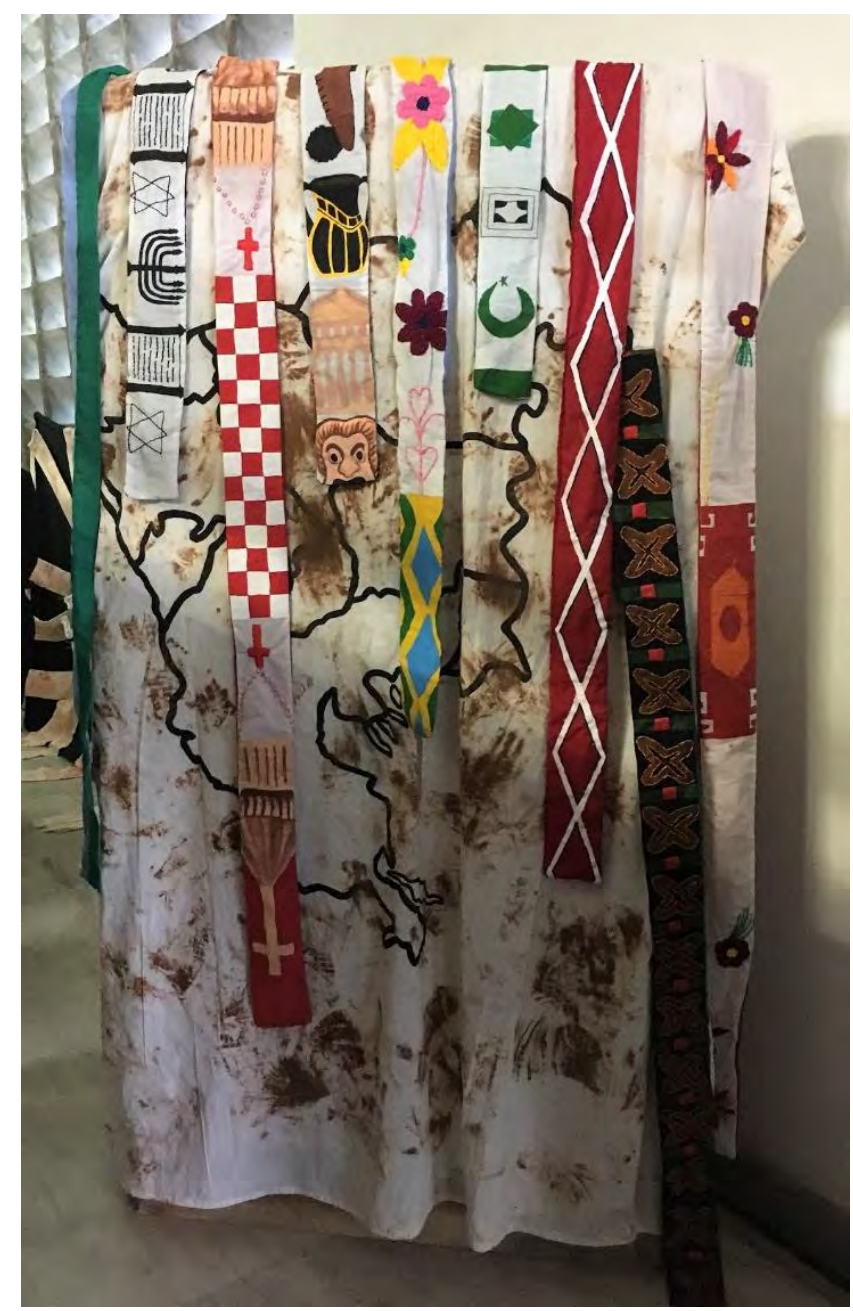

Figura 84 - Detalhe das faixas.

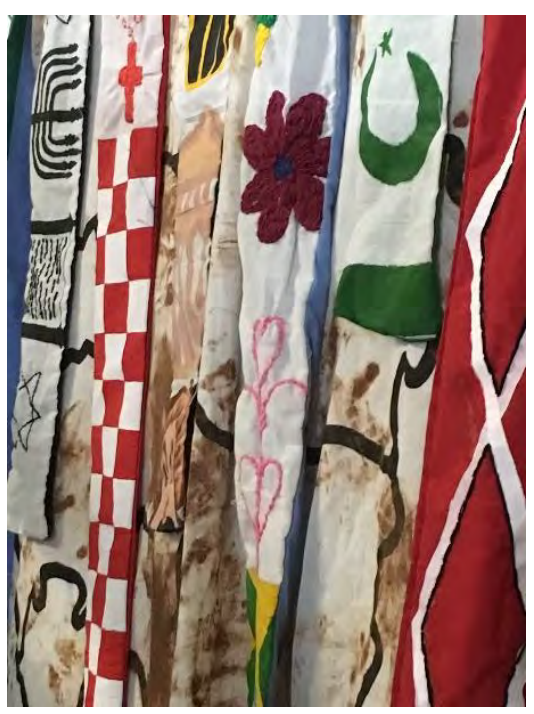

Fonte: Acervo da autora.

Fonte: Acervo da autora.

Para aproximar ainda mais o público da questão, o grupo optou por fazer um traje que não seria usado pelas atrizes, mas sim que fosse colocado na plateia. Inspirado em uma camisa de força, o traje faria com que o espectador fosse amarrado com as faixas contendo símbolos dos países envolvidos na guerra. Desta maneira, o espectador se encontraria na mesma situação de imobilidade que as personagens se encontram naquele momento. Essa ação com a plateia deveria acontecer na Cena 20 (p.147 - 162), em que Kate e Dorra conversam sobre os diversos grupos étnicos e, de maneira irônica, se referem a eles de maneira preconceituosa. Para explanar melhor de que maneira esta ação se daria, o grupo fez uma pequena maquete da ação (Figura 85). Além disso, o grupo também incluiu no seu projeto um diagrama de como se daria a ação e o planejamento dos bordados das faixas. 
Figura 85 - Projeto e maquete do Grupo 2.

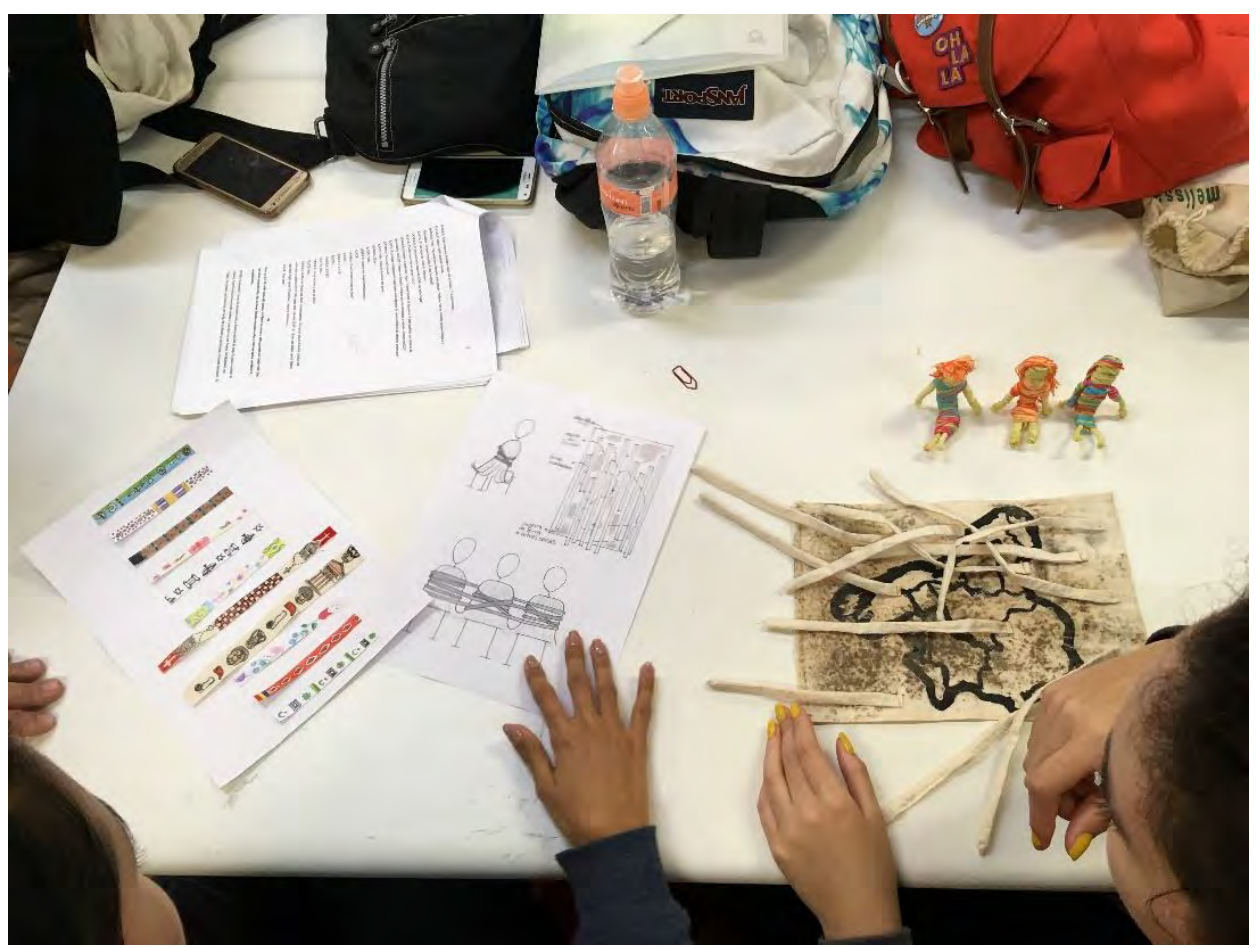

Fonte: acervo da autora.

Todas essas especificações no planejamento se deram também diante do questionamento de como fazer a plateia interagir. Uma das vantagens de se trabalhar com alunos que não são das artes cênicas é que parece haver grande liberdade de pensamento na hora de criar. Os alunos que têm maior experiência com o teatro tendem a saber de antemão que interação com o público é uma ação delicada que precisa ser bem planejada, pois nem sempre é vista com bons olhos. Para os alunos da moda este tabu não era tão latente e, por isso, lhes parecia possível realizar qualquer tipo de relação.

\subsubsection{Bordado contemporâneo}

O Grupo 3 criou uma obra que dialoga muito com os temas que o bordado tem trabalhado nas artes visuais: as questões de gênero. A obra tem duas partes: um traje e um biombo que o oculta. A ideia do grupo é que o público, ao chegar no espaço do espetáculo, irá se deparar com essa estrutura cheia de fendas através das quais deverá olhar (Figuras 86 e 87). As fendas se assemelhavam a um órgão sexual feminino. Segundo a descrição do projeto do grupo (Anexo I):

Inicialmente, o traje estará sobre um manequim, o qual se encontrará entre dois painéis, fixos em uma estrutura de madeira, que estarão o escondendo do público. Ambos os painéis estarão desgastados, possuirão manchas vermelhas, fendas e marcas de mãos, representando a violação causada à vítima do estupro. Através das fendas 
será possível que os espectadores observem o traje por vários ângulos diferentes, com o intuito de colocar o espectador no lugar do agressor, para assim enxergar o mal que ele causa à vítima. (GRUPO 4, 2017)

Figura 86 - Obra 4 (Painel)

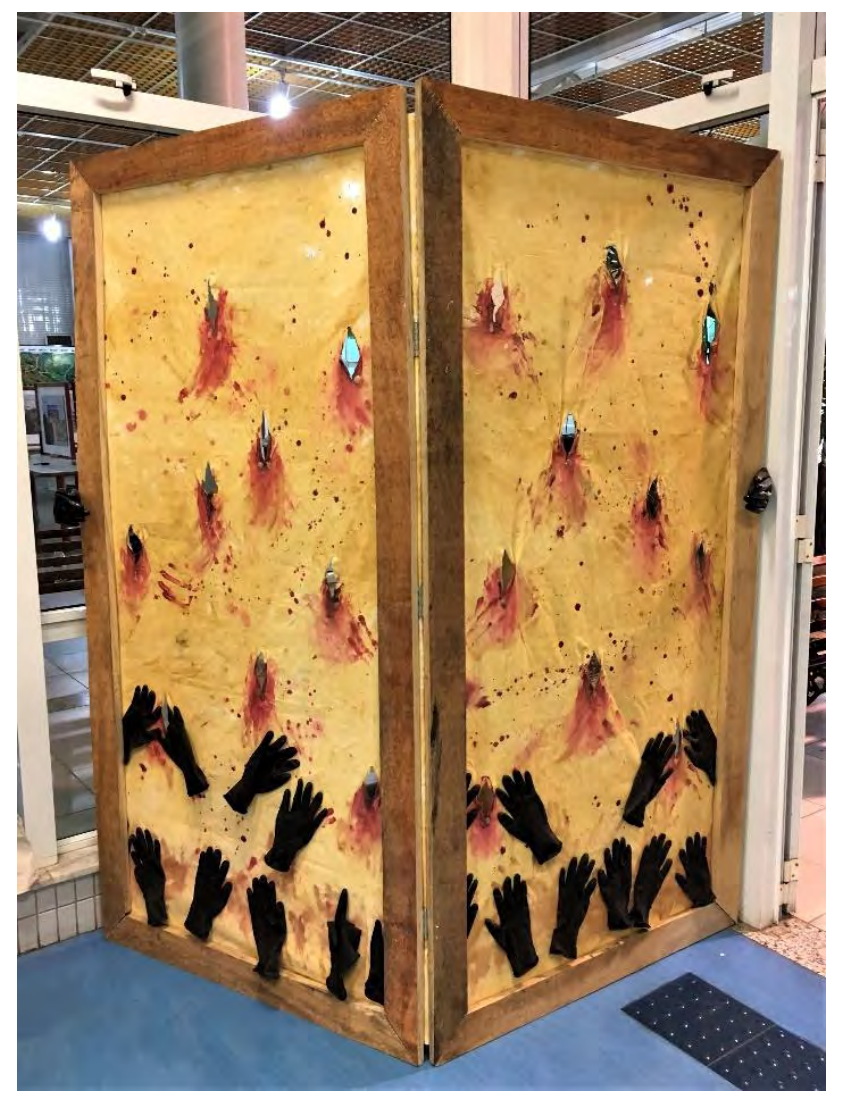

Figura 87 - Detalhe do painel

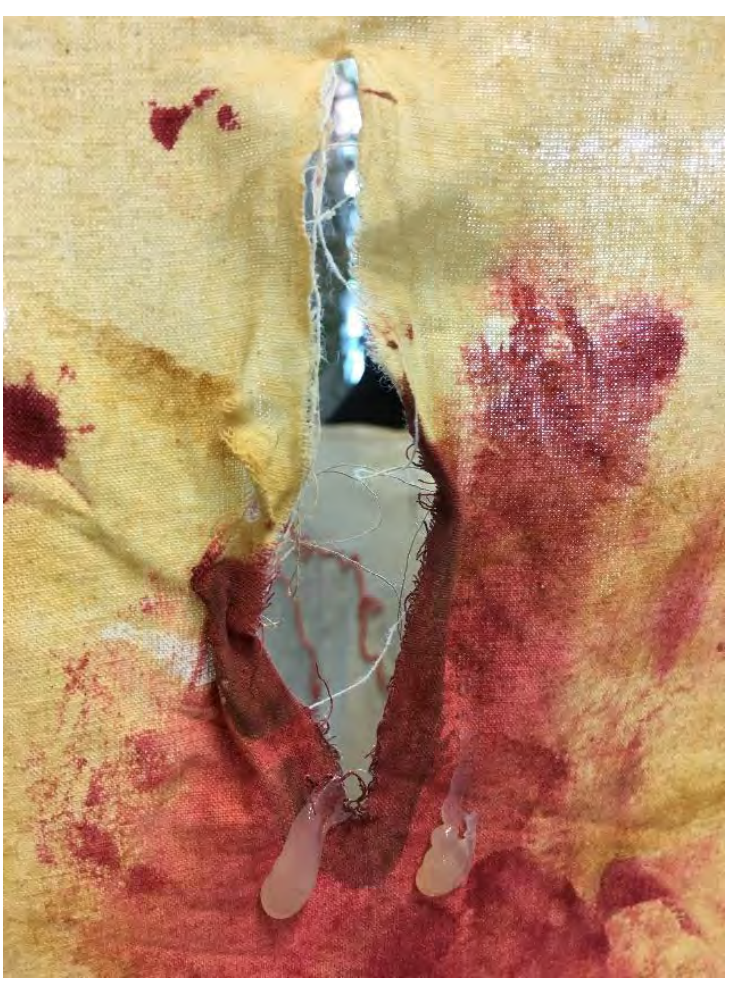

Fonte: Acervo da autora

Fonte: Acervo da autora

A capa, que seria usada pela personagem Dorra, é feita de retalhos de diversas manchetes de jornal e estatísticas acerca da questão da violência sexual no Brasil (Figuras 88 e 89). Os dados foram recortados e rebordados na capa, causando uma ruptura no tecido e. além disso, o grupo bordou em miçangas diversas linhas vermelhas que são ao mesmo tempo como veias por onde corre sangue e rastros de uma violência. Assim como o painel, a capa tem diversas manchas de sangue, inclusive de sapatos, como se tivesse sido pisada. Ao utilizar dados de um local diferente daquele que é retratado na peça o grupo denuncia que o problema da violência de gênero não se restringe a alguma época ou cultura específica. 


\section{Figura 88 - Obra 4 (Capa)}

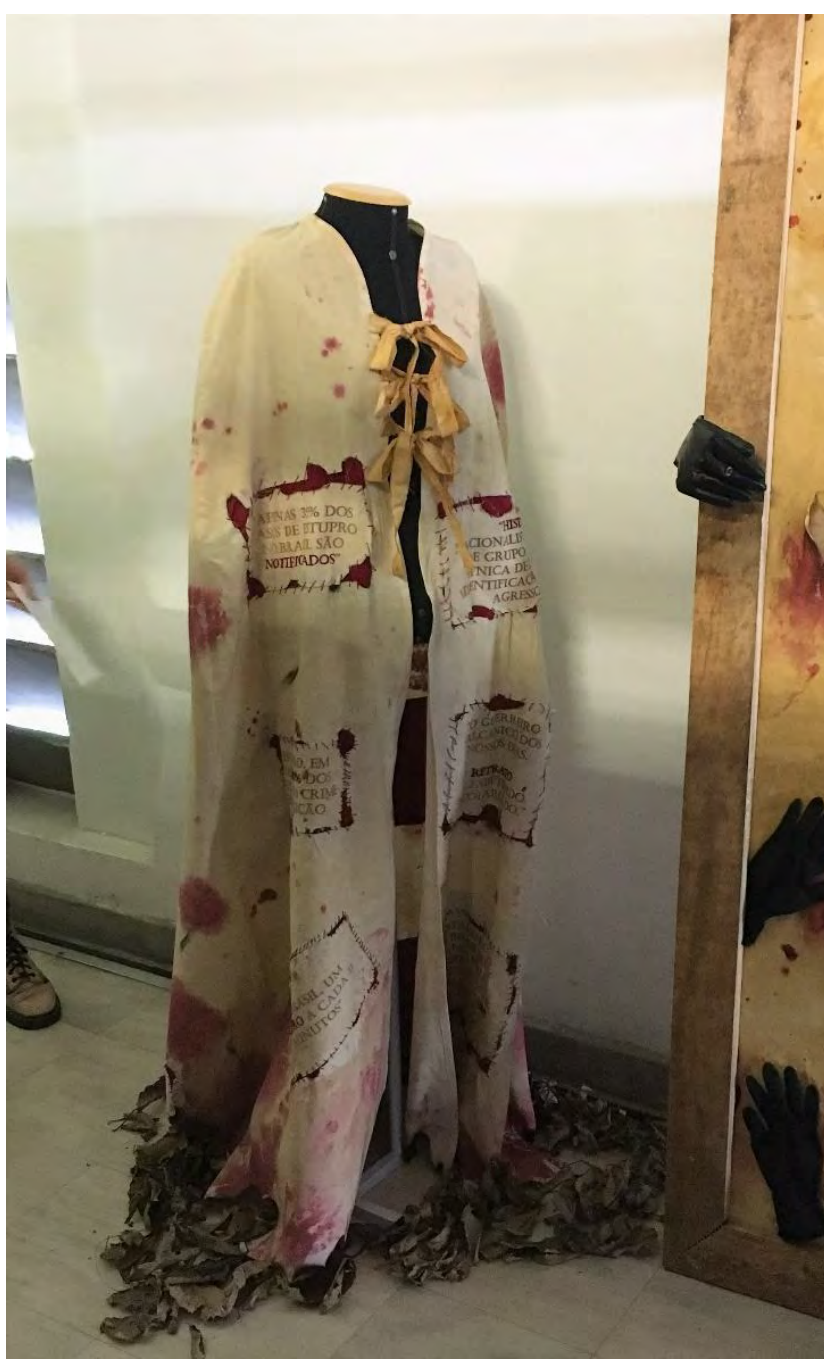

Figura 89 - Detalhe dos dados escritos na capa.

Fonte: Acervo da autora

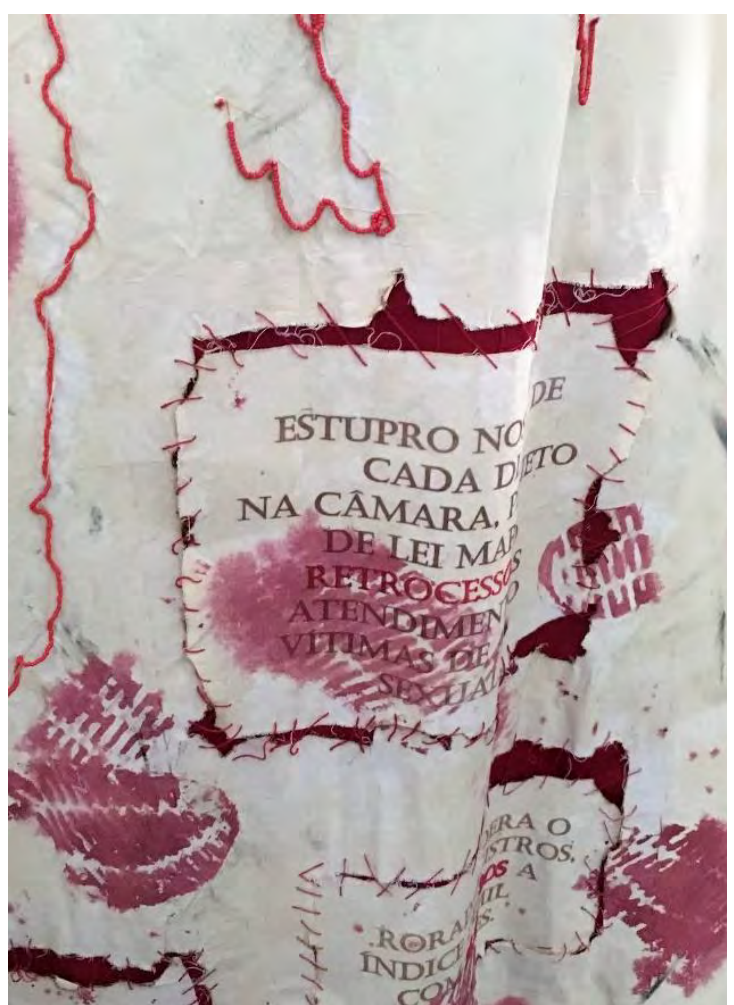

Fonte: Acervo da autora

A violência sexual contra a mulher foi uma arma de guerra durante o conflito nos Balcãs. Segundo descrição da personagem Dorra,

Hoje em dia, nas guerras étnicas, o estupro é uma forma de guerra-relâmpago. Nada pode desestabilizar com mais eficácia o inimigo étnico do que quando se viola sua mulher. Mais da metade das mulheres violadas no contexto das guerras interétnicas foram vítimas de agressores, ou que elas conheciam, ou que encontravam pelas ruas num perímetro de menos de sessenta quilômetros. Aproximadamente metade das mulheres que pudemos entrevistar declarou que os homens que as violaram são habitantes da mesma cidade ou de cidades vizinhas. Quase um quarto das mulheres com quem pudemos conversar pôde dar o nome ou os nomes de seus agressores. (VISNIEC, 2012, p.118) 
Segundo o estudo do IPEA (2011) Estupro no Brasil: uma radiografia segundo os dados da Saúde ${ }^{117}$, indica que, de modo geral, considerando-se todas as fases da vida de uma pessoa - infância, adolescência e vida adulta - 70\% dos agressores são conhecidos da vítima. Os graus de parentesco variam desde pais, tios, avós até namorados e amigos, o que indica que a violência contra as mulheres não parte apenas de desconhecidos. Esta é uma questão semelhante à apontada por Dorra na sua fala. A guerra interétnica ocorre entre diferentes etnias que até então conviviam no mesmo espaço. São vizinhos, colegas de trabalho e antigos amigos que agora estão em lados opostos. No conflito da peça havia ainda um agravante: a xenofobia.

\begin{abstract}
Para resumir, com seu inimigo sendo seu irmão, o guerreiro sabe que as mulheres que rodeiam seu inimigo são ao mesmo tempo sua fonte de vitalidade e seu ponto mais frágil. Os combatentes não violam por puro prazer selvagem ou por causa da tentação sexual. O estupro é uma forma de estratégia militar para desmoralizar o inimigo. O estupro, no caso concreto das guerras interétnicas na Europa, tem o mesmo objetivo que a destruição das casas do inimigo, das igrejas ou dos lugares sagrados do inimigo, dos seus vestígios culturais e dos seus valores. (VISNIEC, 2012, p.119)
\end{abstract}

Ao trabalhar com a denúncia de situações de violência de gênero e xenofobia o grupo se alinha com uma tendência contemporânea de aplicação do bordado ligada à sua revalorização nas artes visuais: a assumida de um papel questionador. A manipulação de têxteis - como o bordado e o crochê - sempre associada aos trabalhos domésticos é plataforma para diversos artistas que buscam ressignificar técnicas, visando não só uma subversão do olhar engessado sobre a arte, como propriamente dos papéis de gênero na sociedade.

A obra criada pelo grupo dialoga também com as artes plásticas ao propor uma instalação. Neste momento de ressignificação do bordado e de questionamento dos limites entre arte e artesanato, muitos artistas têm trazido para o público aquilo que era doméstico. Independentemente das razões que levaram à classificação do bordado como uma arte aplicada, ou cotidiana, atualmente estes limites já não são mais tão fixos.

Para Prain (2011) política e protesto são partes inerentes da vida e os têxteis não se abstém de responder a estas narrativas que também existem no cotidiano. Para ela:

O tecido tem sido uma ferramenta de comunicação política através da história, e por vezes foi um meio de comunicação em locais onde era ilegal, ou mesmo letal, falar ou escrever. Têxteis podem ser usados de maneira subversiva para contar histórias porque são artes que parecem inofensivas aos menos observadores. (p.79)

\footnotetext{
${ }^{117}$ Disponível em:

$<$ http://www.ipea.gov.br/portal/images/stories/PDFs/nota_tecnica/140327_notatecnicadiest11.pdf $>$ Acesso em 03 Out.2018.
} 
Em momentos de crise ou tensão, os artistas respondem esteticamente às pressões. No caso do bordado, não é apenas nas mensagens das obras que está o caráter subversivo, mas sim na própria presença da técnica nos museus e galerias. Valorar a arte aplicada da mesma maneira que as artes plásticas e visuais têm sido valorizadas não deixa de ser um manifesto: a arte que pode subverter o sistema vai nascer do cotidiano, das mãos daqueles que pouca voz ou espaço tiveram até então.

\subsubsection{Conclusões sobre o experimento}

A proposta do exercício era, a partir da leitura da peça A mulher como campo de batalha, de Matéi Visniec, realizar paineis sensoriais. Esses paineis comporiam um projeto de encenação da obra e deveriam ter a função tanto de cenografia quanto de traje de cena, ou seja, em algum momento do espetáculo a atriz deve poder trajar esse painel.

A peça já trazia em seu texto a questão da violência de gênero bastante latente, mas ao se tomar como base a relação entre as mulheres e o bordado, comentada em sala de com os alunos, de alguma maneira parece ter se direcionado a discussão. Talvez por esse motivo a maioria das obras tenham tomado gênero como um dos elementos centrais. A outra questão que mais chamou a atenção foi a dos conflitos entre etnias, talvez também motivada pela discussão cotidiana que a crise de refugiados assumiu no mundo hoje.

A maioria dos alunos nunca tinha tido contado com o bordado à mão, mas durante as oficinas demonstraram bastante facilidade na prática. Como muitos dos alunos tinha prática em costura manual, isto também pode ter sido um facilitador. Não havia restrição de materiais, o que tornava possível que os alunos usassem diversas técnicas na construção dos trajes. Ainda que o bordado tenha assumido papéis importantes nos trajes, a técnica não foi usada em grande quantidade. Possivelmente o tempo tenha influído nesta opção mais do que o domínio da técnica.

O exercício tinha a duração de um semestre. Considerando-se todas as etapas iniciais, os alunos tiveram aproximadamente dois meses para a elaboração e confecção do traje em si. O comentário frequente dos alunos era que possivelmente não haveria tempo hábil para realizar tudo aquilo que os alunos desejavam.

É curioso que a maioria dos alunos tenha escolhido fazer um traje para ser utilizado pela personagem Dorra ou, ainda, que nenhum grupo tenha feito um traje para Kate. Possivelmente 
pela situação da peça e pelos fatos que ocorrem com Dorra, sua história os tenha impactado mais fortemente e, por isso, tenha sido mais fácil elaborar seu traje.

Apesar de ter sido mais evidente no exemplo do Grupo 1, os alunos em geral possuíam um campo de referências mais ligado à moda que ao teatro. Este é um movimento que costuma se repetir quando se trabalha com traje de cena para alunos de moda. Parece haver forte interesse dos alunos de moda pelas artes cênicas e um desejo de inclusão neste mercado de trabalho. Inclusive, muitos profissionais que se dedicam ao figurino não tiveram uma formação em teatro, mas sim em moda. Uma proposta de conhecimento interdisciplinar parece se fazer necessária quando neste cenário, para que se possa suprir o conhecimento em artes cênicas que os alunos ainda não possuíam e aproveitar de seus conhecimentos em moda como gatilho para inspiração. 
Conclusão 
Ao longo da pesquisa, o bordado foi referido não pelo termo artesanato, mas sim por artesania. De todos os termos possíveis para designar o trabalho manual, esta opção se deu por uma série de razões. A definição da palavra artesania costuma se ligar às noções de cultura, comunidade e tradição, além da ideia de trabalho manual. Segundo o Manual de diferenciación entre artesanía y manualidad (2015) elaborado pelo FONART (Fondo nacional para el fomento de las artesanías):

É um objeto ou produto de identidade cultural comunitária, feito por processos manuais contínuos auxiliados por implementos rudimentares e alguns de função mecânica que executam certas tarefas. A matéria prima básica transformada geralmente é obtida na região onde habita o artesão. O domínio das técnicas tradicionais de patrimônio comunitário permite ao artesão criar diferentes objetos de variada qualidade e maestria, thes imprimindo, além disso, valores simbólicos e ideológicos de cultura local. A artesania se cria como produto duradouro ou efêmero, e sua função original está determinada no nível social e cultural: neste sentido, pode destinar-se a uso doméstico, cerimonial, decorativo, vestuário ou até como instrumento de trabalho. (MANUAL DE DIFERENCIACIÓN ENTRE ARTESANÍA Y MANUALIDAD, 2015, p.14, tradução nossa)

Esta ligação com a tradição e o aspecto ritual envolvido na produção artesanal são o que diferencia a artesania de outros trabalhos manuais. No mesmo manual de referência, estes trabalhos são denominados manualidades:

Devem entender-se como aquele objeto ou produto que é resultado de um processo de transformação manual ou semi industrializado, a partir de uma matéria prima processada ou pré-fabricada. Tanto as técnicas, como a própria atividade, não possuem uma identidade de tradição cultural comunitária e se perdem no tempo, tornando-se um trabalho datado, marcado pelas modas e praticado a nível individual ou familiar. A criatividade nas manualidades alcança importantes valores estéticos no domínio da transformação técnica e da ornamentação, mas estes carecem de valores simbólicos e ideológicos da sociedade que os cria. (Idem)

A diferença entre artesania e manualidade, portanto, é uma diferença de paradigma temporal: enquanto uma se apoia na tradição e no passado, a outra se apoia no efềmero e no presente. É aqui que o bordado se coloca. Ele remete à uma tradição e a significados míticos milenares.

Diferente dos conhecimentos acadêmicos em geral, o bordado é ligado à oralidade. É um conhecimento que se passa pela conversa e pelo processo empírico: se aprende observando o outro, testando por si próprio aquilo que se adquire pela observação e pela palavra. É um conhecimento que não pode ser puramente abstrato, pois se realiza na concretude da produção. Além disso, se baseia numa estrutura de conhecimento partilhado: se sente junto e se trocam ideias, pontos, dicas e técnicas para bordar porque, justamente por ser normalmente um conhecimento que se adquire no núcleo familiar, não há uma só maneira de ser feito. O bordado, 
portanto, não se liga apenas à tradição das culturas e sociedades como também à tradições pessoais, da ordem do familiar. E neste processo de produção de conhecimento, emergem as narrativas.

Por ser um patrimônio imaterial de conhecimento, mas que se realiza no campo do concreto, ficou claro que era preciso experimentar de maneira prática com o bordado para que a pesquisa fosse mais aprofundada. Era preciso entender os processos envolvidos na produção de conhecimento e obras têxteis. O exercício realizado com os alunos do curso de Têxtil e Moda pôde demonstrar a força da artesania através dos significados que carrega e que dela emergem. Muito do conteúdo das análises não estava planejado pelos alunos, mas as suas vivências pessoais e a história da aplicação do bordado se encarregam de fazer as pontes. Aí também está uma das possibilidades de criação de narrativas do trabalho coletivo: a análise posterior que encontra significados nem sempre pretendidos inicialmente.

Na formação do pensamento mítico ocidental, a produção de narrativas está muito ligada à ideia do têxtil, principalmente relacionadas às mulheres. Calvino (1993), diz sobre o aparecimento dos têxteis na mitologia greco-latina, diz que:

\footnotetext{
"A precisão técnica com que Ovídio descreve o funcionamento dos teares durante o desafio [de Aracne a Minerva] pode indicar-nos uma possível identificação do trabalho do poeta com a tecelagem de uma tapeçaria púrpura multicolorida. (...) as Metamorfoses pretendem representar o conjunto do que é passível de ser narrado transmitido pela literatura com toda a força de imagens e de significados que ele comporta, sem decidir - segundo a ambiguidade propriamente mítica - entre as chaves de leitura possíveis." (CALVINO, 1993, p.34)
}

Para Calvino, fica claro que o trabalho de bordar é uma metáfora para o trabalho de narrar; e que esses trabalhos são muito poderosos. Mas narrar, diferente do que o senso comum costuma ditar, não está necessariamente ligado apenas às palavras.

Para tentar dar conta de resolver dramaticamente uma ideia ou acontecimento, por muito tempo o teatro se aproximou da estrutura formal literária da composição, ou seja, da noção que uma história se constrói parte por parte e que seria preciso que se organizasse uma série de imagens, ações e conteúdos diversos, numa ordem específica, para que se passasse a mensagem ao leitor/espectador. Com isso, durante muito tempo, o teatro do ocidente acabou privilegiando o texto escrito.

Esse privilégio ao texto escrito influiu na maneira como esse teatro foi representado ao longo do tempo. Tomando-se, seguindo as pressuposições de Williams (2010), o teatro grego como sendo onde o teatro potencialmente teria nascido, vê-se que o estilo da encenação era de 
caráter declamativo, com cenários estáticos e com convenções conhecidas por todos, onde figurinos tinham a função de adornar e diferenciar as personagens entre si de acordo com suas funções em cena. Guardadas as devidas diferenças históricas e culturais, esse parece ter sido em alguma medida o padrão durante muito tempo. Ainda que o teatro tenha se modificado muito desde então, uma característica se manteve por um longo período: a peça já estava planejada no texto escrito. Tanto o modo como ia ser representada - gestos, tons de fala e outro - quanto a sua ambientação - luz, cenografia e figurino - já estavam dados no texto e, por isso mesmo, quase sempre subordinadas a ele.

A partir do séc. XIX a encenação começa a se modificar e adquirir contornos e vicissitudes que lhe permitem possibilidade de criação. Dort (2010), "Somente por volta de 1820 se começa a falar em encenação na acepção que hoje conferimos ao literário tendo em vista sua representação teatral: a encenação de um romance, por exemplo, era a adaptação cênica deste romance" (p.83-84, 2010). A partir desse período, surgem diversas correntes estéticas que procurarão reformular o modo como se pensa e executa teatro.

Onde então, neste cenário, o bordado poderia ter potencial narrativo?

Para responder essa questão é preciso que se pense outros tipos de narrativas possíveis, principalmente em narrativas visuais, ou seja, aspectos não verbais da encenação, que além de compor a história, também possuem seus próprios significados. A cenografia, a iluminação e o figurino se colocam neste campo.

Por conta do primado do texto escrito, por muito tempo esses elementos tinham caráter funcional. Eles gravitavam em torno do texto, e tinham a função de ilustrar o que era determinado pela dramaturgia, mantendo coerência e objetividade ao buscar representar o período retratado de maneira fiel. Com isso também, os profissionais envolvidos nessas funções puderam adquirir mais autonomia artística e passaram a explorar mais possibilidades de criação de universos e estéticas. A partir do séc. XIX, o teatro passa a explorar novas maneiras de narrar suas histórias e, com isso, muitas novas possibilidades de contar histórias visualmente emergem.

Esta pesquisa se abre com uma breve história dos usos do bordado nos trajes, porque era preciso que se fizesse um salto no campo dos significados. Afinal, o que pode significar um bordado? Mais do que um item decorativo - ainda que não seja em hipótese alguma uma função de menor importância - um bordado pode assumir outras funções quando presente num traje. Um bordado pode ter aspecto ritual, pode assumir a função de identificação, pode ressignificar 
um traje e pode apresentar narrativas, sejam elas expressas na materialidade, ou seja, nos padrões e símbolos bordados, ou na abstração, a partir dos processos de feitura do bordado.

Ao se filiar a uma tradição que identifica no traje de cena uma origem ritual e assumindo que ele transforma o corpo do ator em corpo da personagem quando entra em cena, só se pode entender um trabalho manual como carregado de sentido se ele também for fonte de tradição e simbologia. A artesania, ou seja, o trabalho manual poético sobre o traje, pode ser elemento definidor na criação de trajes de cena.

Sennett (2008) defende que o artesão é aquele que possui uma "mão inteligente", ou seja, uma naturalidade nos gestos do fazer manual. O artesão aprende com o tempo, a prática e a repetição o domínio da técnica e é excelente nela justamente por conta do tempo que se dedica a ela. Um iniciante só se preocupa que aquilo que faz dê certo, que possua aquele resultado que ele considera correto. É só com o domínio da técnica que ela deixa de ser uma atividade mecânica e o artesão passa a ter consciência do que realiza.

É nesta pressuposição de Sennett que parece se centrar uma das grandes questões da artesania no traje de cena. Mais do que um elemento decorativo, o trabalho manual no traje depende de consciência. Não há gratuidade no fazer e nem deve ser seu propósito principal que ela simplesmente "dê certo" visualmente. O figurinista que faz da artesania um aspecto importante em sua criação transforma o traje através da sua dedicação a ele. "O artesão representa a condição humana especial de se dedicar" (Sennett, 2008, 1.304, tradução nossa).

Os estudos de caso presentes na pesquisa orbitam em torno de Arthur Bispo do Rosário, uma figura cuja história não pode se descolar da artesania e do bordado. Na pesquisa, se apontam duas possíveis influências da biografia de Bispo que podem tê-lo aproximado do trabalho artesanal: o contato com os folguedos de sua cidade natal, principalmente a Chegança, e o tempo na Marinha Brasileira. Ainda que não haja em nenhuma fonte consultada afirmação do próprio Bispo acerca do assunto, a estética desenvolvida por ele parece se relacionar com estas passagens.

Em O homem de la mancha, há uma tentativa de reproduzir, na medida do possível, as obras têxteis de Bispo, principalmente as vestíveis (a saber, os fardões e o Manto da Apresentação). A escolha do artista como figura inspiradora da visualidade do espetáculo norteou não só a cenografia e figurino, como também provocou adaptações no roteiro da peça, deslocando o conflito de um presídio para um hospício nos anos 1930 no Brasil. Há também, na concepção do figurino, um início de aproximação do modo de trabalho de Bispo. 
Na análise do processo criativo de Gabriel Villela se evidencia uma aproximação ainda maior entre os processos criativos de ambos os artistas. Não só Bispo inspira Villela no campo do visual, como também no campo do fazer da arte. Villela ressignificar trajes de um espetáculo para outro e uma das principais ferramentas para essa prática é o bordado. Assim como Bispo do Rosário, o bordado em Villela modifica o significado na peça sobre a qual é aplicado e remete a uma tradição local e uma ancestralidade.

Apesar de obras com perfis e objetivos diferentes, tanto os trajes da produção O homem de la mancha quanto os trajes de Gabriel Villela têm em comum um elemento: elas identificam no bordado potencial além do decorativo. Ambos acessam o bordado como forma de contar histórias visualmente e têm nele um gatilho criador. O potencial desta técnica de contar histórias pode e deve ser explorado por aqueles encenadores que enxerguem na artesania uma resposta para as inquietações do mundo.

Alguns assuntos ligavam as personagens que transitaram esta pesquisa: a vida militar, a loucura, os folguedos e, principalmente, a relação entre o trabalho manual e a memória. Esses assuntos todos também se encontravam na peça $A$ mulher como campo de batalha com um adicional: tratavam também da questão de gênero e do papel da mulher na sociedade. Era o ponto que faltava para fechar a pesquisa e costurar os assuntos levantados.

Foi preciso restringir o corpus da pesquisa para que esta não ficasse por demais extensa ou carecesse de profundidade. Há, no entanto, muitos casos a se estudar em que o bordado é um elemento capaz de criar narrativas nos trajes de cena. Talvez atores bordando trajes em cena e documentando a temporada. Talvez performers bordando na própria pele - modificação corporal, aliás, também é traje de cena? Talvez público e atores bordando juntos os trajes de cena. As possibilidades são muitas e ainda pouco exploradas, tanto nas realizações cênicas quanto nos estudos. Que essa pesquisa possa ser um primeiro ponto neste tecido. E que ainda haja muitas histórias bordadas no futuro! 


\section{Referências Bibliograficas}

ALEKSIÉVITCH, S. A guerra não tem rosto de mulher. Tradução de Cecília Rosas. $1^{\mathrm{a} e d .}$ São Paulo: Companhia das Letras, 2016.

ANÔNIMO. The Elizabethan Embroidery. Worcestershire: Read Books Ltd, 2013.

ARTAUD, Antonin. Van Gogh: O suicidado pela sociedade. Rio de Janeiro: Rizoma Editorial, 2017.

BARBER, Elizabeth Wayland. Women's work: the first 20,000 years: women, cloth, and society in early times. Nova Iorque: W. W. NORTON \& COMPANY, 1994

BARBIERI, Donatella. Costume in Performance: Materiality, Culture and the Body. Londres: Bloomsbury, 2017.

BARTHES, R. O Prazer do Texto. 5a ed. São Paulo: Perspectiva, 2010

BENJAMIN, W. O narrador. Considerações sobre a obra de Nikolai Leskov. In: Magia e Técnica, Arte e Política: ensaios sobre literatura e história da cultura. $7^{\mathrm{a} e d}$. São Paulo: Brasiliense, 1994. (Obras escolhidas; v.1)

A obra de arte na era de sua reprodutibilidade técnica. Primeira versão.

In: Magia e Técnica, Arte e Política: ensaios sobre literatura e história da cultura $.7^{\mathrm{a} e d}$. São Paulo: Brasiliense, 1994. (Obras escolhidas; v.1)

BENTLEY, T. Costumes by Karinska. New York: Harry N. Abrams, INC, 1995.

BRYAN-WILSON, Julia. Fray: art and textile politics. Chicago: The University of Chicago Press, 2017.

CALVINO, Italo. As odisseias na Odisséia. In: Por que ler os clássicos. $2^{\mathrm{a}} \mathrm{ed}$. São Paulo: Companhia das Letras, 1993.

. Ovídio e a contiguidade universal. In: Por que ler os clássicos. $2^{\mathrm{a} e d . ~ S a ̃ o ~}$ Paulo: Companhia das Letras, 1993.

CARVAlHO, José Murilo de. Pontos e Bordados: escritos de história e política. Belo Horizonte: Editora UFMG, 1999.

CLUCKIE, Linda. The Rise and Fall of Art Needle. Bury Saint Edmunds: Arena Books, 2008. Edição do Kindle. 
CUNNINGHAM, Rebecca. The Magic Garment: Principles of Costume Design. Nova Iorque: Longman Inc., 1989.

DANTAS, Marta. Arthur Bispo do Rosário: a poética do delírio. São Paulo: Editora UNESP, 2009.

DAYAS, Inés Antón. Jewels de Balanchine. La joyería hecha Danza. Danzaratte: Revista del Conservatorio Superior de Danza de Málaga, ISSN-e 1886-0559, Nº 7, 2011, p.33-41.

DHAMIJA, Jasleen. Asian Embroidery. Nova Dheli: Abhinav Publications. Edição do Kindle, 2004.

DORT, Bernard. O teatro e sua realidade. Tradução de Fernando Peixoto. $2^{\mathrm{a}}$ ed. São Paulo: Perspectiva, 2010

GHNAIM, Wafa. Tatreez \& Tea: Embroidery and Storytelling in the Palestinian Diaspora. Nova Iorque: Wafa Ghnaim. Edição do Kindle, 2016.

GIL, Maria Celina. O bordado narrativo nos trajes de Game of Thrones. In.: Dos bastidores eu vejo o mundo [recurso eletrônico]: cenografia, figurino, maquiagem e mais - volume 2. Org. VIANA, Fausto e MOURA, Carolina Bassi de. São Paulo: ECA/USP, 2017. 320 p.

GIUNTA, Edvige e SCIORRA, Joseph. Embroidered Stories: Interpreting Women's domestic needlework from the Italian Diaspora. Jackson: University Press of Mississippi, 2014.

HAYWARD, John. O homem armado. Revista L'oeil, número 49, janeiro de 1959, p. 53 Tradução Fausto Viana e Sophia Jobim.

HIDALGO, Luciana. Arthur Bispo do Rosário: o senhor do labirinto. Rio de Janeiro: Rocco Digital, 2012. Ebook.

ITALIANO, Isabel e VIANA, Fausto. Para vestir a cena contemporânea: moldes e moda no Brasil do século XIX. São Paulo: Estação das Letras e Cores, 2015.

JEROY, Judy. Creative Crewel Embroidery: Traditions \& Innovations. Nova Iorque: Lark Books, 2000.

KELLY, Mary B. The Ritual Fabrics of Russian Village Women. In: GOSCILO, Helena e HOLMGREEN, Beth. Russia-women-culture. Bloomington: Indiana University, 1996. p. 152 $-176$. 
KENDRICK, A. F. Introduction. In: A book of old embroidery. Org. Geoffrey Holme. Londres: The Studio, 1921.

LEFÉBURE, Ernest. Embroidery and Lace; Their Manufacture and History. New York: G. P. Putnam. Edição do Kindle, 2016.

LESLIE, Catherine Amoroso. Needlework through history: an encyclopedia. Londres: Greenwood press, 2007.

MARTIN, Richard e KODA, Harold. Haute Couture. Rhode Island: The Metropolitan Museum of Art, 1995.

MOURA, Carolina Bassi de. A direção e a direção de arte: construções poéticas da imagem de Luiz Fernando Carvalho. 2015. 473 f. Tese (Doutorado em Artes) - Escola de Comunicação e Artes, Universidade de São Paulo. São Paulo.

MUNIZ, Rosane. Vestindo os nus: o figurino em cena. Rio de Janeiro: Editor Senac Rio, 2004 PAINE, Sheila. Embroidered Textiles. Londres: Thames \& Hudson, 2010.

PARKER, Rozsika. The Subversive Stitch: Embroidery and the Making of the Feminine. Londres: I. B. Tauris, 2010.

PAVIS, Patrice. Dicionário de teatro. $3^{\mathrm{a}}$ ed. São Paulo: Perspectiva, 2008.

PEREIRA, Dalmir Rogério. Alinhaves entre traje de cena e moda: estudos a partir de Gabriel Villela e Ronaldo Fraga. 2012. 157p. Dissertação (Mestrado em Artes Cênicas). Departamento de Pós Graduação em Artes Cênicas da Escola de Comunicação e Artes da Universidade de São Paulo, São Paulo, 2012.

PEREIRA, Dalmir Rogério; Viana, Fausto; Muniz, Rosane . As Delicadas Tramas de Gabriel Villela. In: Quadrienal de Praga, 2011, Praga. Diário dos Pesquisadores. São Paulo: FUNARTE, 2011. p. 75-80.

PRAIN, Leanne. Hoopla: the art of unexpected embroidery. Vancouver: Arsenal Pulp Press, 2011. Edição Eletrônica.

Strange Material: Storytelling through Textiles. Vancouver: Arsenal Pulp Press, 2014. Edição do Kindle.

SAAVADRA, Miguel de Cervantes. O engenhoso fidalgo D. Quixote de la Mancha, Primeiro Livro. São Paulo: Editora 34, 2002.

SATRAPI, Marjane. Bordados. São Paulo: Companhia das Letras, 2010. 
SENNETT, Richard. Artesanía, tecnología y nuevas formas de trabajo + "Hemos perdido el arte de hacer ciudades". Buenos Aires: Katz Editores, 2015.

The craftsman. New Heaven: Yale University Press, 2009.

STALLYBRASS, Peter. O casaco de Marx: roupa, memória, dor. $5^{\text {a }}$ edição. Belo Horizonte: Autêntica Editora, 2016.

TOVAR, Claudio. Box de croquis dos figurinos de $\mathbf{O}$ homem de la mancha. Sem editora, sem data.

VIANA, Fausto. $\mathbf{O}$ figurino teatral e as renovações do século XX. $2^{\mathrm{a}}$ ed. Revisada e ampliada. São Paulo: Estação das Letras e Cores, 2016.

. Para documentar a história da moda: de James Laver às blogueiras fashion. São Paulo: ECA/USP, 2017.

VIANA, Fausto e MUNIZ, Rosane. O Figurino de Gabriel Villela: dramaturgia e poéticas têxteis. In: Imaginai! O teatro de Gabriel Villela. Org. Dib Carneiro Neto e Rodrigo Audi. São Paulo: Edições Sesc São Paulo, 2017.

VIEIRA, Maria Augusta da Costa. Apresentação de D. Quixote. In: O engenhoso fidalgo D. Quixote de la Mancha, Primeiro Livro. São Paulo: Editora 34, 2002.

VISNIEC, Matéi. A mulher como campo de batalha ou Do sexo da mulher como campo de batalha na Guerra da Bósnia. Tradução: Luiza Jatobá. São Paulo: É Realizações, 2012.

WASSERMAN, Dale. Man of La Mancha. Nova Iorque: Laurel-Leaf Library, 1966.

WHEELER, Candace. The development of embroidery in America. Nova Iorque: Harper \& Brother, 1921.

WIERZCHOWSKI, Letícia. A casa das sete mulheres. São Paulo: Editora Record, 2003.

WILliAMS, Raymond. Drama em cena. Tradução de Rogério Bettoni. São Paulo: Cosac Naify, 2010.

\section{Webgrafia}

BRAYSHAW, Emily. Stitching lives back together: men's rehabilitation embroidery in WW1. 2017. Disponível em: <https://theconversation.com/stitching-lives-back-togethermens-rehabilitation-embroidery-in-wwi-76326> Acesso em: 01 Jul.2017. 
BRITO, T. F. S. de. Bordados e Bordadeiras: Um estudo etnográfico sobre a produção artesanal de bordados em Caiacó/RN. 2010. 285 folhas. Tese (Doutorado em Antropologia). Departamento de Antropologia da Faculdade de Filosofia, Letras e Ciências Humanas, Universidade de São Paulo, São Paulo. 2010. Disponível em: $<$ http://www.teses.usp.br/teses/disponiveis/8/8134/tde-15122011-175001/pt-br.php $>$ Acesso em: 23 Jun.2017.

CLAPTON, Michelle. 28 Fascinating facts about the "Game of Thrones" costumes. [12 de Agosto, 2016]. Entrevista concedida ao Buzzfeed. Disponível em: $<$ https://www.buzzfeed.com/keelyflaherty/facts-about-the-game-of-thrones-costumes-youprobably-nev> Acesso em 26 Set.2018.

. Inside the newbattle-ready looks of the "Game of Thrones" queens. [28 de junho, 2017]. Entrevista concedida a Kim Renfro. Disponível em: $<$ https://www.thisisinsider.com/game-of-thrones-costume-designer-michele-claptoninterview-2017-6> Acesso em 26 Set.2018.

COLLIER, Ann Futternan. The Well-Being of Women Who Create With Textiles: Implications for Art Therapy. Art Therapy: Journal of the American Art Therapy Association, 28(3) pp. 104-112: 2011. Disponível em: $<$ https://www.researchgate.net/publication/233291654_The_Well-

Being_of_Women_Who_Create_With_Textiles_Implications_for_Art_Therapy $>$ Acesso em 29 Jun.2017.

COSTA FILHO, José Almir Valente. Arthur Bispo do Rosário: uma poética em processo. 2007. 155 f. Dissertação (Mestrado em Artes Visuais)- Universidade de Brasília, Brasília, 2007. Disponível em: < http://repositorio.unb.br/handle/10482/5514> Acesso em 27.set.2018.

GABRIEL Villela. In: ENCICLOPÉDIA Itaú Cultural de Arte e Cultura Brasileiras. São Paulo: Itaú Cultural, 2018. Disponível em: $<$ http://enciclopedia.itaucultural.org.br/pessoa359371/gabriel-villela $>$ Acesso em: 30 Set.2018. Verbete da Enciclopédia;

FIGUEIREDO, Alda de Moura Macedo. Manto da Apresentação: Arthur Bispo do Rosário em diálogo com Deus. 2010. 127 folhas. Dissertação (Mestrado em Viência da Arte). Proggrama de Pós-Graduação em Ciência da Arte, Universidade Federal Fluminense, Niteroi, 
2010. Disponível em: <http://www.artes.uff.br/dissertacoes/2010_alda_figueiredo.pdf $>$ Acesso em 26 Set.2018.

FONART. Manual de diferenciación entre artesania y manualidad. Cidade do México: $\begin{array}{lllll}\text { Secretaría de Desarrollo } & \text { social, } & \text { Disponível } & \text { em }\end{array}$ $<$ https://www.gob.mx/cms/uploads/attachment/file/107963/Manual_diferenciacion_artesania_ manualidad_2015.pdf $>$ Acesso em 03 set. 2018.

FRANCO, Stéfanie Gil. 22 Dezembro 1938 - Arthur Bispo do Rosário: um estudo antropológico sobre arte e loucura. 2011. Dissertação (Mestrado em Antropologia). Programa de Pós-Graduação em Antropologia Social, Departamento de Antropologia da Faculdade de Filosofia, Letras e Ciências Humanas, Universidade de São Paulo, São Paulo, 2011. Disponível em: <http://www.teses.usp.br/teses/disponiveis/8/8134/tde-25052012100620/pt-br.php> Acesso em 30 Ago. 2017.

FREEMAN, Margaret B. The T. Martin Embroideries. Greenwitch: The Metropolitan Museum of Art, 1969. Disponível online em: $<$ https://www.metmuseum.org/art/metpublications/the_st_martin_embroideries $\geq$ Acesso em 10 Dez. 2017.

GUCCINI, Gerardo. "Cultural resistence" in the Eastern European countries through the “Project Recherche" and MatéiVisniec's Dramaturgy. In: D. M. A., P.P., P.T. Differences on Stage.2013. Disponível em: <https://books.google.com.br/books?id=3gxBwAAQBAJ\&printsec $=$ frontcover\&hl $=$ pt-BR\#v=onepage \&q\&f=false $\geq$ Acesso em 01 Jun. 2018.

HAYT, Elizabeth. The hands that sew sequins. Site do New York Times, 19 de janeiro de 2006. Disponível online em: $<$ http://www.nytimes.com/2006/01/19/fashion/thursdaystyles/the-hands-that-sew-thesequins.html> Acesso em 12 Dez. 2017.

MACHADO, Ana Maria. O tao da teia - sobre textos e têxteis. 2003. Disponível em: $<$ http://www.scielo.br/scielo.php?script=sci_arttext\&pid=S0103-40142003000300011> Acesso em 22 Mai. 2018.

NASCIMENTO, Ana Maria Barbosa do. Pespontos nos trajes de Candomblé: Os trajes sagrados de Nóla de Araújo. 2016. 201 folhas. Dissertação (Mestrado em Artes Visuais). Programa de Pós-Graduação em Artes Visuais na Escola de Belas Artes da Universidade 
Federal da Bahia. Salvador, 2016. Disponível em: $<$ http://www.ppgav.eba.ufba.br/sites/ppgav.eba.ufba.br/files/dissertacao_ana_nascimento_fin al.pdf> Acesso em 26 Set.2018.

OLIVEIRA, Solange de. Uniformes e re-bordados de Bispo do Rosário: mundo desconstruído e ressiginificado. 163 folhas. Dissertação (Mestrado em Ciências). Programa de Pós-Graduação em Têxtil e Moda da Escola de Artes, Ciências e Humanidades da Universidade de São Paulo, São Paulo, 2012. Disponível em: $<$ http://www.teses.usp.br/teses/disponiveis/100/100133/tde-01022013-152635/pt-br.php> Acesso em 30 Set.2018.

PANTOUVAKI, Sofia. Embodied interactions: Towards na exploration of the expressive and narrative potential of performance costume through wearable technologies. In: Scene n. 2, vol. $1 \&$ 2, p. $179 \quad$ - 196, out. 2014. Disponível em: $<$ https://www.intellectbooks.co.uk/journals/view-Article,id=18647/> Acesso em 22 Ago. 2018.

PEÑUELA-CANIZAL, E. Entrevista com Eduardo Peñuela. Novos Olhares, n. 8, p. 29-34, 30 dez. 2001. Disponível em: <https://www.revistas.usp.br/novosolhares/article/view/51359> Acesso em 22 out. 2018.

SILBERSTEIN, Rachel. Fashionable Figures: Narrative Roundels and Narrative Borders in Nineteenth-Century Han Chinese Women's Dress, Costume, 50:1, 63-89, 2016. DOI: 10.1080/05908876.2015.1129859. Disponível em: $<$ http://www.tandfonline.com/doi/full/10.1080/05908876.2015.1129859 Acesso em 11/12/2017>. Acesso em 10 Dez. 2017.

SILVA, Paulo Fernando Teles de Lemos e. Bordados tradicionais portugueses. 2006. 133 folhas. Dissertação (Mestrado em Design e Marketing). Departamento de Engenharia Têxtil, Universidade do Minho. Braga, 2006. Disponível em: $<$ https://repositorium.sdum.uminho.pt/bitstream/1822/6723/1/TESE_PAULO.pdf $>$ Acesso em 26 Set.2018.

STEVENSON, William F. Barbara Karinska: her career, tutus, and functional design for the dancer. TA 660 -Spring 2011. Disponível em: <http://www.academia.edu/4810102/TA660_Karinska_Paper_spring2011> Acesso em 02 Ago. 2018. 
VIANA, Fausto Roberto Poço. Fontes documentais para o estudo da história da moda e da indumentária: o caso James Laver e novas perspectivas. 2015. 212 folhas. Dissertação (Mestrado em Ciências). Programa de Pós-Graduação em Têxtil e Moda, Escola de Artes, Ciências e Humanidades, Universidade de São Paulo. São Paulo, 2015. Disponível em: $<$ http://www.teses.usp.br/teses/disponiveis/100/100133/tde-16122015-125257/pt-br.php> Acesso em 21 Set. 2018.

WATT, Melinda. English Embroidery of the Late Tudor and Stuart Eras. In: Heilbrunn Timeline of Art History. New York: The Metropolitan Museum of Art, 2010. Disponível em: $<$ http://www.metmuseum.org/toah/hd/broi/hd_broi.htm $\geq$ Acesso em 15 Dez. 2017.

\section{Sites}

Alta Moda. Disponível em: < https://artsandculture.google.com/exhibit/fgJS-m1 A4V1zLw> Acesso em 12 Out.2018.

Archivio Médici Costume Textiles. Disponível em: <http://archiviomedici.costumetextiles.com/cerca.asp> Acesso em 11 Jan.2018.

Associação de Folguedos Populares de Alagoas. Disponível em: $<$ http://asfopal.blogspot.com/p/folguedos.html> Acesso em 20 Jun.2018.

Centro Nacional do Folclore e Cultura Popular. Disponível em: $<$ http://www.cnfcp.gov.br/tesauro/apresentacao.html> Acesso em 26 Set.2018.

Ernest Thesieger. Embroidery. Disponível em: $<$ http://ernestthesiger.org/Ernest_Thesiger/Embroidery.html $>$ Acesso em 01 Jul. 2017.

Disabled Soldiers Industry. Disponível em: $<$ http://ernestthesiger.org/Ernest_Thesiger/Disabled_Soldiers_Embroidery_Industry.html $>$ Acesso em 01 Jul. 2017.

Folha Revista. Disponível em: <http://clicfolha.com.br/materia/51528/a-bordadeira-degabriel> Acesso em 22 Mar. 2017.

George Balanchine. Jewels. Disponível em: < http://balanchine.com/jewels $>$ Acesso em 25 Set.2018.

Grupo Galpão. Disponível em: <http://www.grupogalpao.com.br/> Acesso em 21 Mar. 2017. 
Man of la mancha. Disponível em: <http://www.musicalheaven.com/m/man-of-la-mancha/> Acesso em 10 Jun. 2018.

Michele Carragher Embroidery. Disponível em: $<$ http://www.michelecarragherembroidery.com/index.htm> Acesso em 26 Set.2018.

Memória Feita a Mão. Disponível em: <http://memoriafeitaamao.blogspot.com.br $>$ Acesso em 20 Mar. 2017.

Museu Arthur Bispo do Rosário. Disponível em: <http://museubispodorosario.com/> Acesso em 25 Mar. 2017.

Museu Etnogrático Russo. Moldavos. Final do XIX - início do século XX. Disponível em: $<$ http://ethnomuseum.ru/moldavane-konec-xix-nachalo-xx-v> Acesso em 26 Set. 2018.

Prefeitura de Carmo do Rio Claro. Disponível em: <http://www.carmodorioclaro.mg.gov.br/> Acesso em 21 Mar. 2017.

Prefeitura de Japaratuba. Disponível em: $<$ https://www.guiadoturismobrasil.com/cidade/SE/628/japaratuba> Acesso em 15 Jun.2018.

Sinhá Olympia. Disponível em: <https://tccolympia.wordpress.com/> Acesso em 29 Mar. 2017.

\section{Referências Audiovisuais}

CINCO Perguntas para Gabriel Villela. Site O Primeiro Sinal. São Paulo: Site O Primeiro Sinal, 2013. (8 m). Disponível em: <https://www.youtube.com/watch?v=ATgc8eTXRxU> Acesso em 29 Mar. 2017.

ENSAIO Aberto Brasil - Grupo Galpão. Direção: Luiz Cruiz. São Paulo: MPMIDIA, 2014. (26 m). Disponível em: <http://canalcurta.tv.br/pt/filme/?name=grupo_galpao> Acesso em 29 Mar. 2017.

GAME of Thrones. Criação: David Benioff e D. B. Weiss. EUA e Reino Unido: Television 360 / Grok! Television / Generator Entertainment / Startling Television / Bighead Littlehead, 2011 - [ainda em produção], 57min por episódio aproximadamente.

JEWELS - Behind the Costumes (The Royal Ballet). 2011. (7m33s). Disponível em: $<$ https://www.youtube.com/watch?v=msLjmbPFmT4> Acesso em 26 Set.2018. 
P ág in a | 153

Anexos 


\section{ANEXO I - EXEMPLO DE PROJETO}

\section{Conceito gerador}

Após a leitura do texto "A mulher como campo de batalha" realizada em sala foram discutidas diversas formas de interpretação que poderiam inspirar projetos de representação, baseados em trechos do texto, por meio de materiais têxteis aliados à intervenções como pintura, transfer de imagens, bordados, dentre outros. Para tal, foram desenvolvidas individualmente propostas de aproximadamente $40 \times 40 \mathrm{~cm}$.

Nesta etapa, foi possível perceber que o tema estupro foi discutido e apresentado em diversas facetas como o horror sentido pela vítima, a violação do corpo e direitos, os traumas resultantes, a sensação de desconforto causada em quem ouve relatos de uma vítima e até mesmo a esperança pós trauma.

Neste trabalho a faceta que será representada é a da violação do corpo, a sensação de fragilidade e impotência mediante a presença de um abusador.

\section{Como vestir/pendurar?}

O traje de cena escolhido para representar o tema é a capa. Neste traje haverá transfer de imagens de manchetes reais de jornais sobre estupros e, bordados de palavras extraídas do texto "A Mulher como campo de batalha".

Inicialmente, o traje estará sobre um manequim, o qual se encontrará entre dois painéis, fixos em um estrutura de madeira, que estarão o escondendo do público. Ambos os painéis estarão desgastados, possuirão manchas vermelhas, fendas e marcas de mãos, representando a violação causada à vítima do estupro. Através das fendas será possível que os espectadores observem o traje por vários ângulos diferentes, com o intuito de colocar o espectador no lugar do agressor para assim enxergar o mal que ele casa a vítima. 


\section{Desenhos}

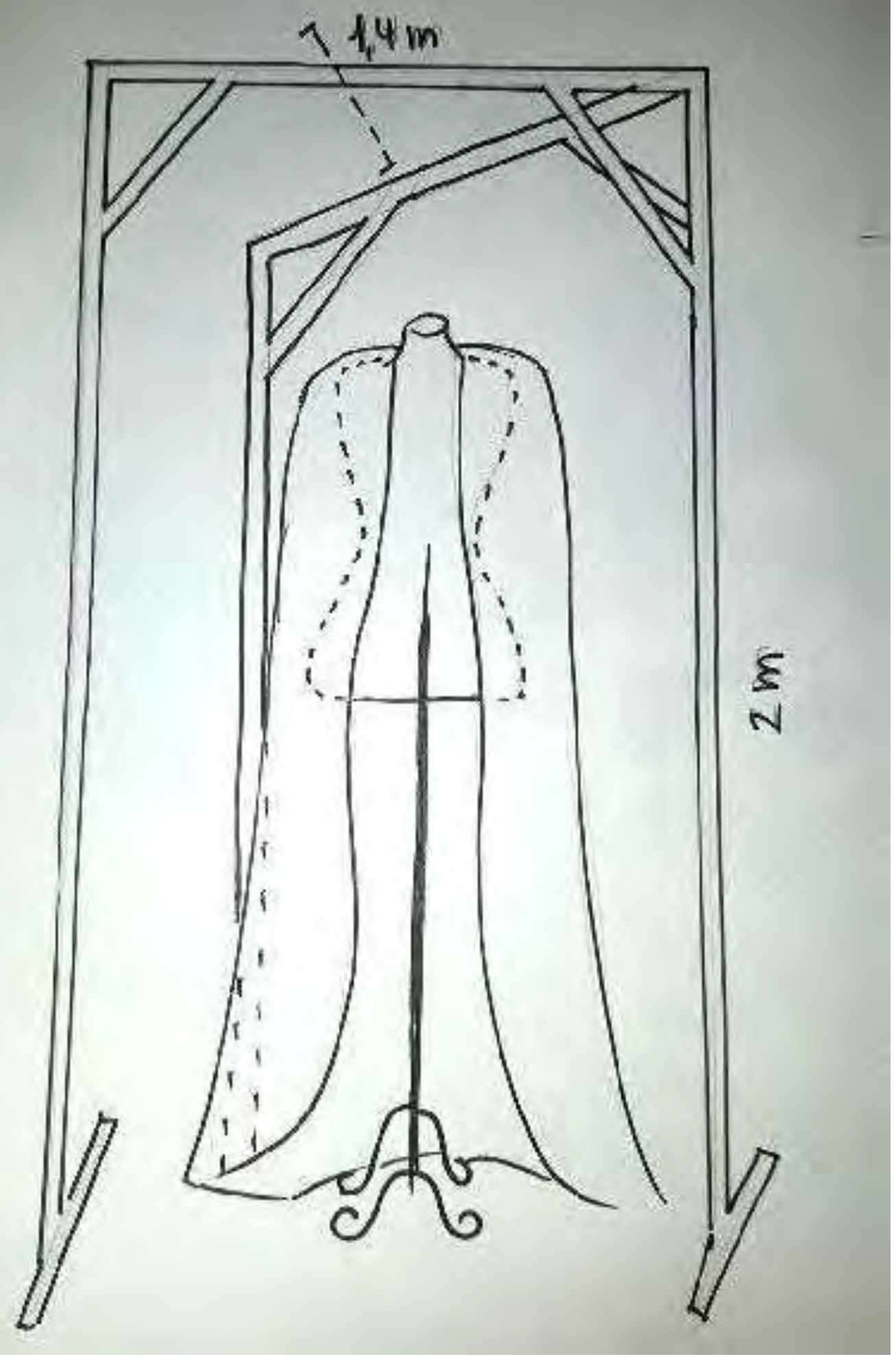




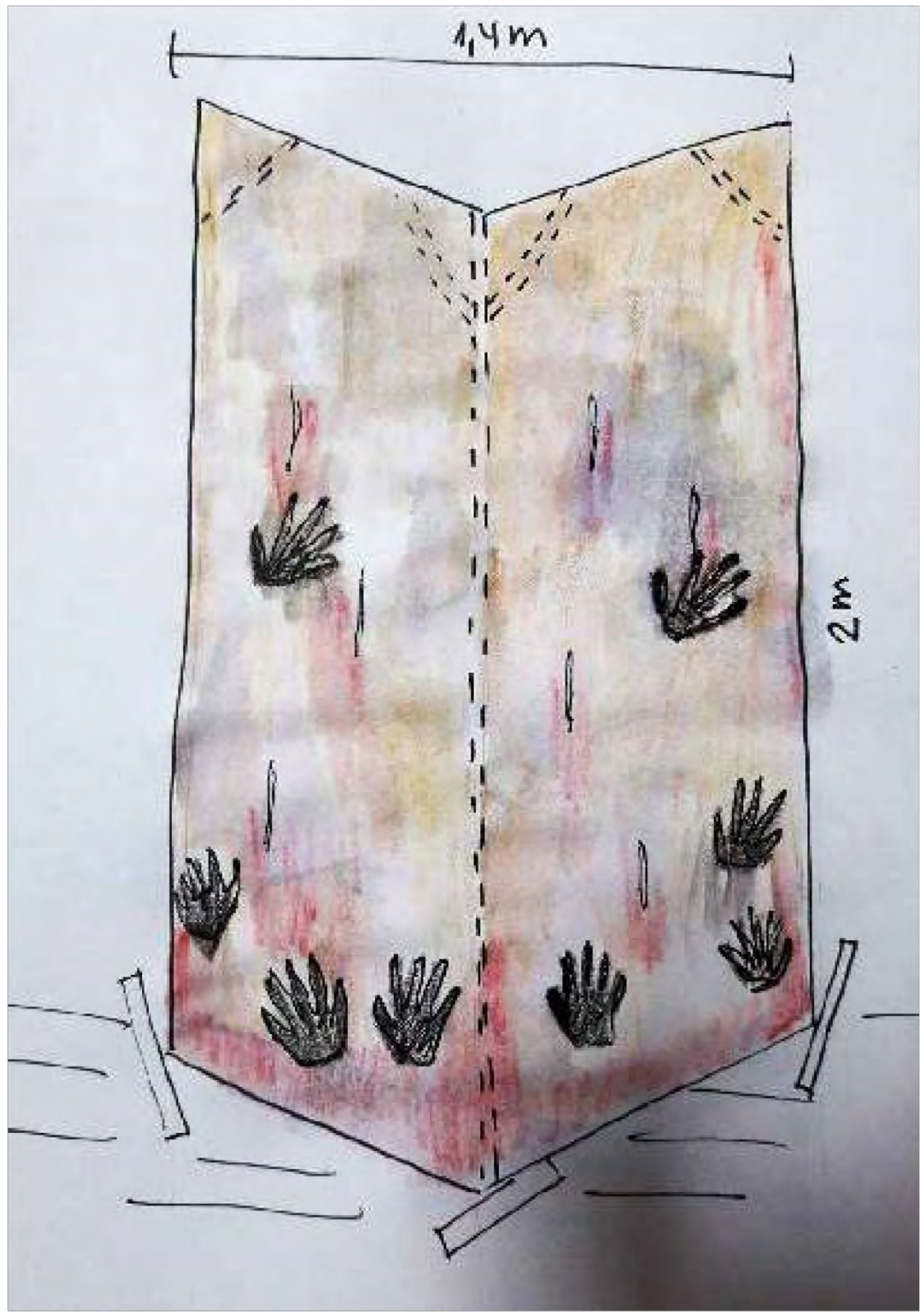

\section{Materiais}

Para apresentar o trabalho utilizaremos materiais que remetem a sensações que o texto apresenta, utilizando:

- tecido algodão cru/tricoline para o painel e na capa;

- papel para transfer de imagens; 
- corantes vermelhos (ou algo que não seque fácil como a tinta);

- linhas para bordado;

- miçangas para bordado;

- $\quad$ estrutura em cano/madeira para sustentar o(s) painel(is);

- busto que sustentará a capa/traje.

\section{Cores}

Para este projeto, propõe-se composições entre cores terrosas como bege presente nos tecidos crus, corantes avermelhados e os bordados em linha preta a fim de destacar as palavras e formas. Abaixo, uma proposta de cores:
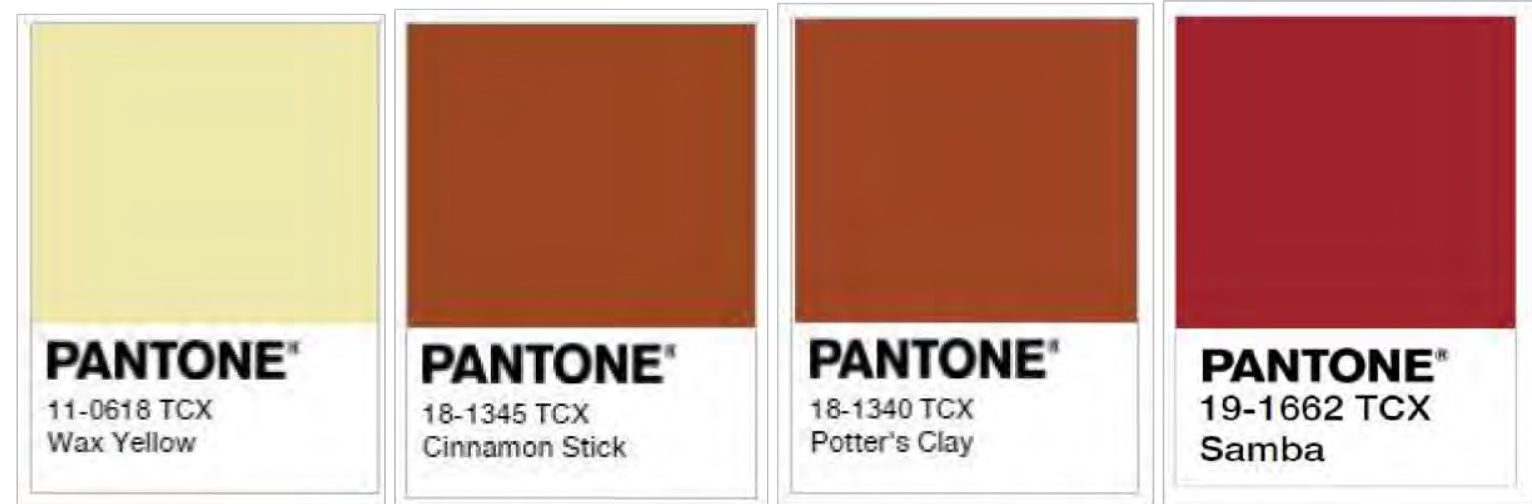

\section{PANTONE}

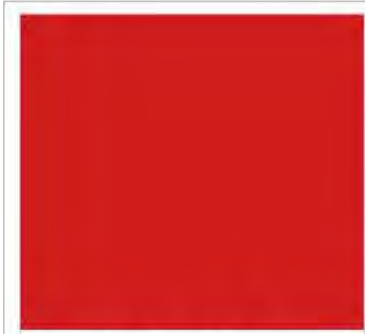

PANTONE 18-1664 TCX Fiery Red

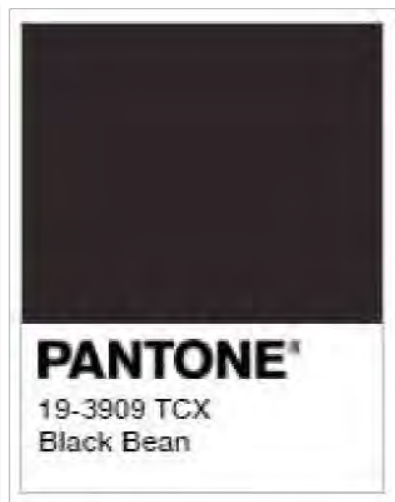

\section{Quanto custa e quanto tempo leva pra fazer?}

Com base na lista de materiais citada acima estima-se, a partir de um levantamento de preços médios, que o custo seja de $\mathbf{R} \mathbf{\$ 1 2 9 , 6 4}$. Nota-se que o cálculo de custo total foi feito com os maiores valores de cada item, a partir da seguinte compilação de preços:

- algodão cru/tricoline para o painel e capa: R\$ 5,99/R\$6,40 (metro). Portanto, $6 \mathrm{~m}=$ $35,94 / \mathbf{3 8}, \mathbf{4 0}$. 
- papel para transfer de imagens: $\mathbf{R} \$ \mathbf{3 7 , 0 0}$ (pacote com 10 folhas A4)

- corante: $\mathbf{R} \$ \mathbf{2 , 9 0}$ (40g tingem $300 \mathrm{~g}$ de tecido)

- linhas para bordado: $\mathbf{R} \$ \mathbf{1 , 6 0}$ (metro)

- miçangas para bordado: $\mathbf{R} \mathbf{\$ 7 , 8 0}$ (vidro com $28 \mathrm{~mL}$ )

- estrutura em madeira para sustentar os painéis: 1 painel $=3$ ripas de madeira $=$ $\mathrm{R} \$ 20,97$. Caso sejam 2 painéis: $\mathbf{R} \$ \mathbf{4 1 , 9 4 .}$

- busto que sustentará a capa/traje: $\mathrm{R} \$ 0,00$ (pertence a um membro do grupo).

Estima-se que o tempo de produção seja de 3 horas para as estruturas de madeira, 12 horas para a confecção dos painéis e 12 horas para a confecção da capa, totalizando em 27 horas de trabalho.

\section{Sites consultados}

Bazar horizonte. Linha rubi brilhante. Disponível em:

http://www.bazarhorizonte.com.br/linha-rubi-brilhante/p.

Bazar horizonte. Miçanga cristal $28 \mathrm{~mL}$, Disponível em: http://www.bazarhorizonte.com.br/hidro-micanga-cristal-28ml/p?p=missanga\&ranking=1\&ty peclick $=3 \&$ ac_pos=header.

Elo7. Algodão cru. Disponível em:

https://www.elo7.com.br/tecido-algodao-cru-venda-por-metro/dp/783576?elo7_source=google_shop\&elo7_med

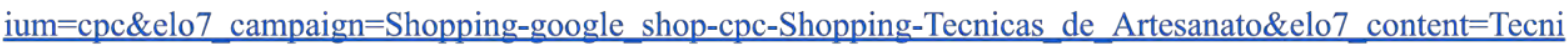
cas_em_geral\&gclid=Cj0KEQjwgODIBRCEqfv60eq65ogBEiQA0ZC5-ajisFT-AEbdCGCmc9gRzEjD12J1ejLp GEm7hrtR48MaAuBL8P8HAQ.

Kalunga. Papel transfer ink jet para tecidos claros, Bright. Disponível em:

http://www.kalunga.com.br/prod/papel-transfer-ink-jet-p-tecidos-claros-(a4)-bright/479684.

Leroy Merlin. Ripa de eucalipto aplainada. Disponível em:

http://www.leroymerlin.com.br/ripa-eucalipto-aplainada-3x100cm-massol_87550820?origin= d2db98e3f733f8e212c0acac.

Pantone. Color finder. Disponível em: https://www.pantone.com/color-finder.

Ponto X tecidos: Disponível em:

https://www.pontoxtecidos.com.br/tricoline-100-alg-lisa/off-Tricoline-100-Alg-lisa. 
Walmart. Corante para tecidos. Disponível em:

https://www.walmart.com.br/corante-para-tecido-tingecor-40g-guarany-09/4360988/pr. 